National Water Quality Program

\title{
Extraction and Development of Inset Models in Support of Groundwater Age Calculations for Glacial Aquifers
}

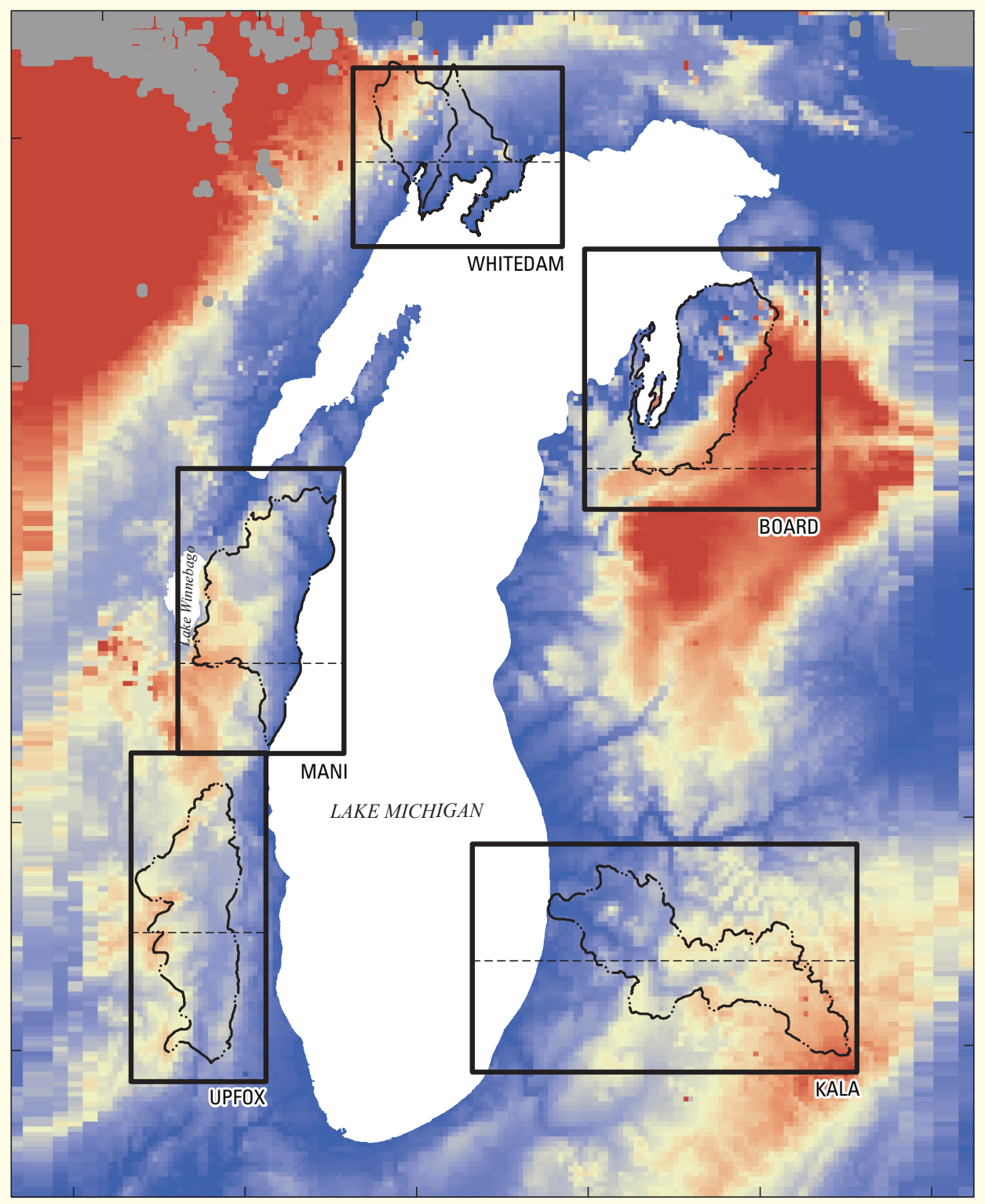

Scientific Investigations Report 2018-5038 
Cover. Location of inset MODFLOW model domains superimposed on simulated 2005 water table for Lake Michigan Basin model (unconfined version). 


\section{Extraction and Development of Inset Models in Support of Groundwater Age Calculations for Glacial Aquifers}

By Daniel T. Feinstein, Leon J. Kauffman, Megan J. Haserodt, Brian R. Clark, and Paul F. Juckem

National Water Quality Program

Scientific Investigations Report 2018-5038 


\title{
U.S. Department of the Interior \\ RYAN K. ZINKE, Secretary
}

\author{
U.S. Geological Survey \\ James F. Reilly II, Director
}

U.S. Geological Survey, Reston, Virginia: 2018

For more information on the USGS - the Federal source for science about the Earth, its natural and living resources, natural hazards, and the environment-visit https://www.usgs.gov or call 1-888-ASK-USGS.

For an overview of USGS information products, including maps, imagery, and publications,

visit https://store.usgs.gov.

Any use of trade, firm, or product names is for descriptive purposes only and does not imply endorsement by the U.S. Government.

Although this information product, for the most part, is in the public domain, it also may contain copyrighted materials as noted in the text. Permission to reproduce copyrighted items must be secured from the copyright owner.

Suggested citation:

Feinstein, D.T., Kauffman, L.J., Haserodt, M.J., Clark, B.R., and Juckem, P.F., 2018, Extraction and development of inset models in support of groundwater age calculations for glacial aquifers: U.S. Geological Survey Scientific Investigations Report 2018-5038, 96 p., https://doi.org/10.3133/sir20185038.

ISSN 2328-0328 (online) 


\section{Contents}

Abstract

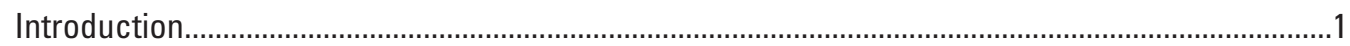

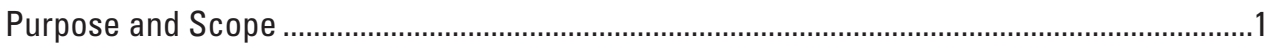

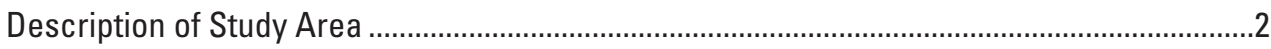

Parent Lake Michigan Basin Model ..................................................................................

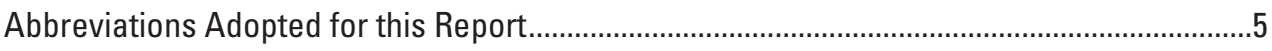

Extraction of Inset Models from Parent Lake Michigan Basin Model..............................................

Inset Model Properties Inherited from the Parent Lake Michigan Basin Model..............................8

Boundary Conditions for Edge Cells and for Lake Michigan ...................................................

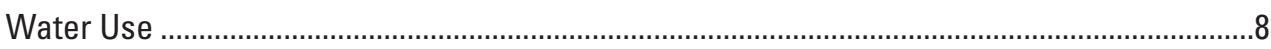

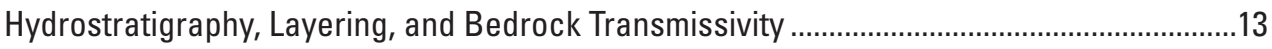

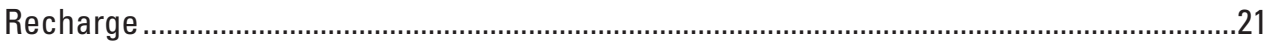

Inset Model Properties Modified from Parent Lake Michigan Basin Model...................................21

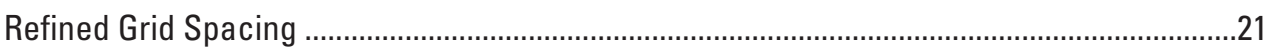

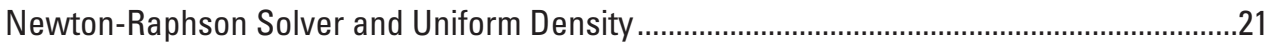

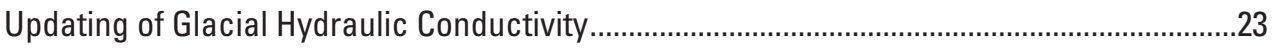

Reconfiguration of Land Surface and Top Bedrock Surface..................................................34

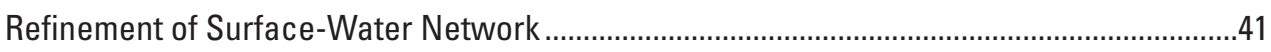

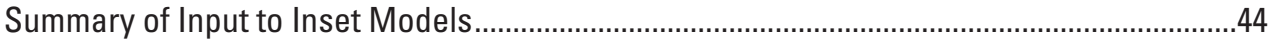

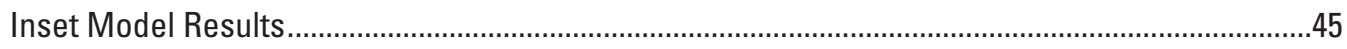

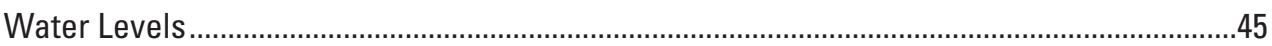

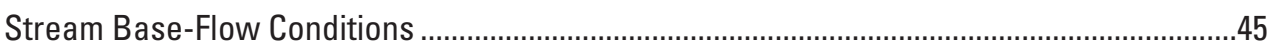

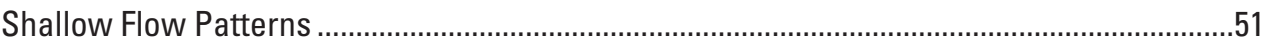

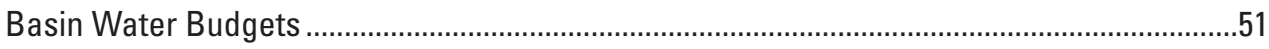

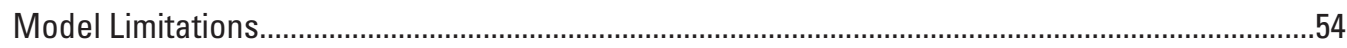

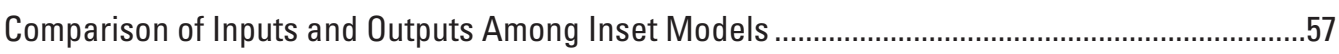

Application of Inset Models to Calculate Age Distribution in Groundwater Discharge

to Glacial Wells..........................................................................................................

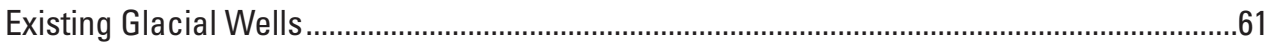

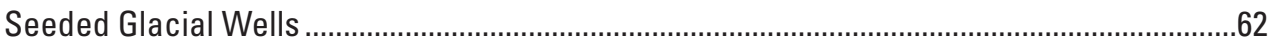

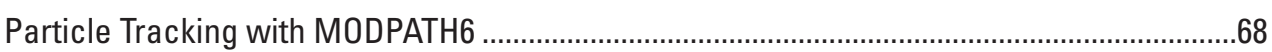

Age Metrics of Groundwater Discharge to Wells ................................................................70

Support for Statistical Modeling of Groundwater Age at Glacial Wells............................................79

Candidate Predictors Extracted from Inset Models ...............................................................

Age Metrics Simulated by MODPATH ...................................................................................

Prospective Statistical Modeling .........................................................................................92

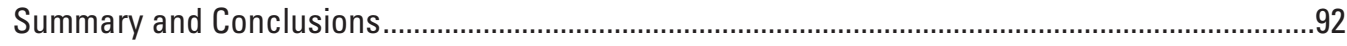

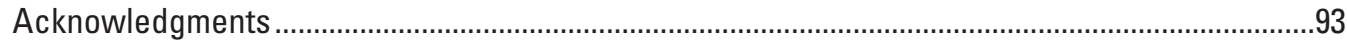

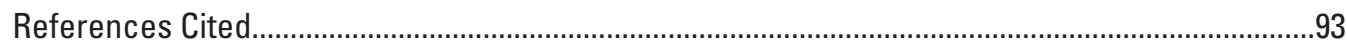




\section{Figures}

1. Map showing lake Michigan Basin MODFLOW model domain ...3

2. Map showing location of inset MODFLOW model domains superimposed on simulated 2005 water table for Lake Michigan Basin model.....

3. Maps showing boundary conditions for inset models $A, \mathrm{KALA} ; B, \mathrm{BOARD}$;

C, UPFOX; D, MANI; and E, WHITEDAM

4. Composite hydrostratigraphic section for Lake Michigan Basin model

5. Hydrostratigraphic cross sections for inset models $A, \mathrm{KALA} ; B, \mathrm{BOARD;}$

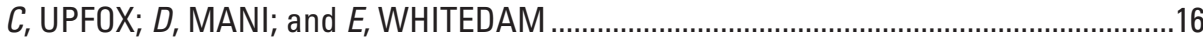

6. Maps showing locations where glacial deposits are absent .............................................20

7. Maps showing annual recharge rate.............................................................................22

8. Maps showing glacial categories in the Lake Michigan Basin model domain.

$A$, layer 1 ; $B$, layer 2 ; and $C$, layer 3 .

9. Graphs showing power-law curves for assigning horizontal hydraulic conductivity to glacial categories based on the spatial distribution of the coarse fraction in layers 1, 2, and 3 of the inset models.

10. Maps showing coarse fraction for glacial deposits at log locations. $A$, layer 1; $B$, layer 2 ; and $C$, layer 3

11. Maps showing interpolated coarse fraction of glacial deposits in layer 1 .33

12. Maps showing horizontal hydraulic conductivity distributions in layer 1 of the KALA basin. $A$, inherited from the Lake Michigan Basin model at 5,000-foot grid spacing and $B$, updated for the KALA inset model at 500-foot spacing.

13. Maps showing composite horizontal hydraulic conductivity distributions across glacial layers

14. Maps showing top of bedrock surface elevation in KALA inset model. $A$, inherited Lake Michigan Basin model surface at 5,000-foot grid spacing; $B$, adjustments to surface on the basis of log information at 5,000-foot grid spacing; and $C$, adjusted and smoothed inset model surface at 500 -foot grid spacing.

15. Maps showing top of bedrock elevation, corresponding to bottom elevation of

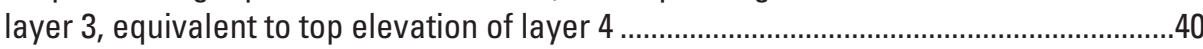

16. Maps showing total saturated glacial transmissivity ..........................................................42

17. Maps showing total saturated model transmissivity contributed by saturated glacial transmissivity.

18. Maps showing minimum distance to active surface-water feature................................46

19. Maps showing simulated water-table elevation ............................................................47

20. Maps showing simulated saturated glacial thickness .....................................................48

21. Maps showing simulated depth to water table below the land surface in top layer cells....

22. Maps showing simulated vertical gradient between the water table in the glacial units and the water level in the uppermost bedrock aquifer

23. Maps showing simulated groundwater flow velocity in model layer 1 ............................52

24. Graphs showing comparison of values or statistical distributions of key inputs and outputs across target HUC8 basins

25. Graphs showing pumping rates for existing high-capacity glacial wells and semi-log trend lines fit to the ranked distribution of pumping for $A, \operatorname{KALA}$; $B$, BOARD; $C$, UPFOX; $D$, MANI; and $E$, WHITEDAM basins 
26. Maps for each inset model showing the locations of seeded wells by layer for an example simulation, along with the locations of existing glacial wells by layer, active water body cells, and the active stream cells for $A$, KALA; $B$, BOARD; $C$, UPFOX; $D$, MANI; and $E$, WHITEDAM

27. Maps showing the locations of seeded and existing glacial wells for target HUC8 basins.

28. Map and histograms showing starting locations, ending locations, and pathlines for a single MODPATH run using 24 active, seeded wells in the KALA inset model .......71

29. Boxplots showing the distribution of the MODPATH age metrics for each inset model . .72

30. Map showing the location and young fraction simulated by MODPATH for glacial wells within the inset model target HUC8 basins.

31. Map showing the location and young fraction simulated by MODPATH for glacial wells within the inset model target HUC8 basins with open intervals below the water table.

32. Map showing the location and simulated median age of the young fraction of discharge for each well for all inset model target HUC8 basins ...

33. Map showing the location and simulated median age of the old fraction of discharge for each well for all inset model target HUC8 basins

34. Graph comparing the simulated values of young fraction of well discharge across all inset model target HUC8 basins using bedrock effective porosity values of 0.08 and 0.02

35. Graphs showing cumulative distribution plots for candidate predictors across all inset model target HUC8 basins.

36. Graphs showing cumulative distribution plots for age metrics across all inset model target HUC8 basins. 


\section{Tables}

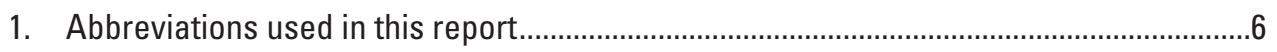

2. Summary of selected inputs for inset model domains .........................................................

3. Status of model layers and units. $A$, units associated with bedrock layers of inset models and $B$, pinched cells in glacial layers.

4. A, Formulation and $B$, inputs to power law for assigning horizontal hydraulic conductivity to glacial deposits in layers 1,2, and 3 of the inset models

5. Kriging parameters for $A$, interpolation of coarse fraction of glacial deposits for inset models using linear semi-variogram and ordinary kriging and $B$, interpolation of bedrock surface for inset models using linear semi-variogram and simple kriging

6. MODFLOW input packages for base inset models

7. Active streamflow routing package (SFR2) cells by stream order for HUC8 basins within inset models.

8. Simulated water budgets for target HUC8 basins within all inset models. $A$, source inflows and sink outflows and $B$, source percentages of total inflows and sink percentages of total outflows.

9. Comparison of budget components for target HUC8 basins—Lake Michigan Basin versus inset models.

10. Number and distribution by layer of existing and seeded glacial wells for target HUC8 basins within inset models

11. Age metrics of groundwater discharge to glacial wells, simulated by MODPATH .........70

12. Candidate predictors for use with prospective metamodel of groundwater age of glacial well discharge

13. Statistical summary of predictors and age metrics for $A$, all glacial wells; $B$, existing glacial wells; and $C$, seeded glacial wells across the target basins. 


\section{Conversion Factors}

U.S. customary units to International System of Units

\begin{tabular}{|c|c|c|}
\hline Multiply & By & To obtain \\
\hline \multicolumn{3}{|c|}{ Length } \\
\hline inch (in.) & 2.54 & centimeter $(\mathrm{cm})$ \\
\hline inch (in.) & 25.4 & millimeter (mm) \\
\hline foot $(\mathrm{ft})$ & 0.3048 & meter $(\mathrm{m})$ \\
\hline mile (mi) & 1.609 & kilometer (km) \\
\hline \multicolumn{3}{|c|}{ Area } \\
\hline acre & 4,047 & square meter $\left(\mathrm{m}^{2}\right)$ \\
\hline acre & 0.4047 & hectare (ha) \\
\hline acre & 0.4047 & square hectometer $\left(\mathrm{hm}^{2}\right)$ \\
\hline acre & 0.004047 & square kilometer $\left(\mathrm{km}^{2}\right)$ \\
\hline square foot $\left(\mathrm{ft}^{2}\right)$ & 929.0 & square centimeter $\left(\mathrm{cm}^{2}\right)$ \\
\hline square foot $\left(\mathrm{ft}^{2}\right)$ & 0.09290 & square meter $\left(\mathrm{m}^{2}\right)$ \\
\hline square inch $\left(\mathrm{in}^{2}\right)$ & 6.452 & square centimeter $\left(\mathrm{cm}^{2}\right)$ \\
\hline square mile $\left(\mathrm{mi}^{2}\right)$ & 259.0 & hectare (ha) \\
\hline square mile $\left(\mathrm{mi}^{2}\right)$ & 2.590 & square kilometer $\left(\mathrm{km}^{2}\right)$ \\
\hline \multicolumn{3}{|c|}{ Volume } \\
\hline gallon (gal) & 3.785 & liter $(\mathrm{L})$ \\
\hline gallon (gal) & 0.003785 & cubic meter $\left(\mathrm{m}^{3}\right)$ \\
\hline gallon (gal) & 3.785 & cubic decimeter $\left(\mathrm{dm}^{3}\right)$ \\
\hline million gallons (Mgal) & 3,785 & cubic meter $\left(\mathrm{m}^{3}\right)$ \\
\hline \multicolumn{3}{|c|}{ Flow rate } \\
\hline foot per second (ft/s) & 0.3048 & meter per second $(\mathrm{m} / \mathrm{s})$ \\
\hline foot per minute ( $\mathrm{ft} / \mathrm{min})$ & 0.3048 & meter per minute (m/min) \\
\hline foot per hour $(\mathrm{ft} / \mathrm{h})$ & 0.3048 & meter per hour $(\mathrm{m} / \mathrm{h})$ \\
\hline foot per day (ft/d) & 0.3048 & meter per day $(\mathrm{m} / \mathrm{d})$ \\
\hline foot per year (ft/yr) & 0.3048 & meter per year $(\mathrm{m} / \mathrm{yr})$ \\
\hline cubic foot per day $\left(\mathrm{ft}^{3} / \mathrm{d}\right)$ & 0.02832 & cubic meter per day $\left(\mathrm{m}^{3} / \mathrm{d}\right)$ \\
\hline gallon per minute (gal/min) & 0.06309 & liter per second (L/s) \\
\hline gallon per day (gal/d) & 0.003785 & cubic meter per day $\left(\mathrm{m}^{3} / \mathrm{d}\right)$ \\
\hline million gallons per day (Mgal/d) & 0.04381 & cubic meter per second $\left(\mathrm{m}^{3} / \mathrm{s}\right)$ \\
\hline $\begin{array}{l}\text { million gallons per day per square mile } \\
\left.\qquad([\mathrm{Mgal}] \mathrm{d}) / \mathrm{mi}^{2}\right)\end{array}$ & 1,461 & $\begin{array}{l}\text { cubic meter per day per square kilometer } \\
\qquad\left(\left[\mathrm{m}^{3} / \mathrm{d}\right] / \mathrm{km}^{2}\right)\end{array}$ \\
\hline \multicolumn{3}{|c|}{ Hydraulic conductivity } \\
\hline foot per day (ft/d) & 0.3048 & meter per day $(\mathrm{m} / \mathrm{d})$ \\
\hline \multicolumn{3}{|c|}{ Hydraulic gradient } \\
\hline foot per mile (ft/mi) & 0.1894 & meter per kilometer $(\mathrm{m} / \mathrm{km})$ \\
\hline \multicolumn{3}{|c|}{ Transmissivity } \\
\hline foot squared per day $\left(\mathrm{ft}^{2} / \mathrm{d}\right)$ & 0.09290 & meter squared per day $\left(\mathrm{m}^{2} / \mathrm{d}\right)$ \\
\hline
\end{tabular}




\section{Datum}

Vertical coordinate information is referenced to the National Geodetic Vertical Datum of 1929 (NGVD 29).

Horizontal coordinate information is referenced to the North American Datum of 1983 (NAD 83).

Elevation, as used in this report, refers to distance above the vertical datum.

\section{Supplemental Information}

Transmissivity: The standard unit for transmissivity is cubic foot per day per square foot times foot of aquifer thickness $\left(\left[\mathrm{ft}^{3} / \mathrm{d}\right] / \mathrm{ft}^{2}\right)$. In this report, the mathematically reduced form, foot squared per day $\left(\mathrm{ft}^{2} / \mathrm{d}\right)$, is used for convenience. 


\title{
Extraction and Development of Inset Models in Support of Ground water Age Calculations for Glacial Aquifers
}

\author{
By Daniel T. Feinstein, Leon J. Kauffman, Megan J. Haserodt, Brian R. Clark, and Paul F. Juckem
}

\section{Abstract}

The U.S. Geological Survey developed a regional model of Lake Michigan Basin (LMB). This report describes the construction of five MODFLOW inset models extracted from the LMB regional model and their application using the particle-tracking code MODPATH to simulate the groundwater age distribution of discharge to wells pumping from glacial deposits. The five study areas of the inset model correspond to 8-digit hydrologic unit code (HUC8) basins. Two of the basins are tributary to Lake Michigan from the east, two are tributary to the lake from the west, and one is just west of the western boundary of the Lake Michigan topographic basin. The inset models inherited many of the inputs to the parent LMB model, including the hydrostratigraphy and layering scheme, the hydraulic conductivity assigned to bedrock layers, recharge distribution, and water use in the form of pumping rates from glacial and bedrock wells. The construction of the inset models entailed modifying some inputs, most notably the grid spacing (reduced from cells 5,000 feet on a side in the parent LMB model to 500 feet on a side in the inset models). The refined grid spacing allowed for more precise location of pumped wells and more detailed simulation of groundwater/ surface-water interactions. The glacial hydraulic conductivity values, the top bedrock surface elevation, and the surfacewater network input to the inset models also were modified. The inset models are solved using the MODFLOW-NWT code, which allows for more robust handling of conditions in unconfined aquifers than previous versions of MODFLOW. Comparison of the MODFLOW inset models reveals that they incorporate a range of hydrogeologic conditions relative to the glacial part of the flow system, demonstrated by visualization and analysis of model inputs and outputs and reflected in the range of ages generated by MODPATH for existing and hypothetical glacial wells. Certain inputs and outputs are judged to be candidate predictors that, if treated statistically, may be capable of explaining much of the variance in the simulated age metrics. One example of a predictor that model results indicate strongly affects simulated age is the depth of the well open interval below the simulated water table. The strength of this example variable as an overall predictor of groundwater age and its relation to other predictors can be statistically tested through the metamodeling process. In this way the inset models are designed to serve as a training area for metamodels that estimate groundwater age in glacial wells, which in turn will contribute to ongoing studies, under the direction of the U.S. Geological Survey National Water Quality Assessment, of contaminant susceptibility of shallow groundwater across the glacial aquifer system.

\section{Introduction}

A study was conducted to extract and develop five inset flow models from the Lake Michigan Basin (LMB) model to be used to determine predictors of the distribution of age of groundwater withdrawn by shallow glacial wells. The inset models contribute to the larger effort undertaken by the U.S. Geological Survey National Water Quality Assessment (NAWQA) to evaluate the intrinsic susceptibility of groundwater to contamination in the principal aquifer systems across the United States, one of which is the glacial aquifer system. Because groundwater age is correlated with the contamination potential of aquifer systems, the age findings of flow models at modeled locations and the possibility of extending those findings beyond the modeled areas by means of statistical techniques are of value in mapping intrinsic susceptibility of groundwater to contamination across the United States. The specific aim of the study was to provide the simulated data needed for a prospective application of statistical modeling to controls on groundwater age.

\section{Purpose and Scope}

This report documents the construction and application of five inset models extracted and refined from a parent regional model. The main purpose of this report is show how five inset models, each derived and refined from a parent regional numerical finite-difference MODFLOW model of the LMB and centered on a target 8-digit hydrologic unit code (HUC8) basin, represent a range of hydrogeologic conditions that affect the simulated age of groundwater discharge to shallow wells. The range of conditions incorporated by the inset models allows them to serve as a training area for a prospective 
statistical model or "metamodel." The prospective metamodel (anticipated by this report and partly described in terms of its predictors and outcomes) is designed to capture the correlation structure of the inputs and outputs of the inset models in such a way as to reproduce, from a limited set of explanatory variables, findings pertinent to the contamination susceptibility of glacial aquifers. In this case, contamination susceptibility is represented by the age distribution of groundwater pumped from wells completed in glacial units (referred to as "glacial wells"). The inset models are process-based tools that detail the physics in a relatively small area, whereas a metamodel trained on the inset models is an easily implemented tool that, if properly constructed and tested, can be applied across large areas, such as the glacial aquifer system of the northern United States.

The aim of the study described in this report is different from that for many other modeling projects in that it is not intended to produce a management tool, but rather to support a statistical tool, which, in turn, will be used to support the assembly of maps and other products in the context of a multiphase project undertaken by NAWQA. The larger NAWQA study is designed to evaluate the intrinsic susceptibility to groundwater contamination in the principal aquifer systems across the United States, one of which is the glacial aquifer system. The overall project objectives are detailed in Burow and Belitz, 2014. The present study represents a contribution to this larger effort.

This report consists of four major parts with sections devoted to

- the extraction, development, and results of the five refined inset models, using the MODFLOW NewtonRaphson Solver (MODFLOW-NWT) code (Niswonger and others, 2011);

- a systematic comparison of the input and output among the inset models, detailing the range of conditions encountered;

- application of the inset models, using the MODPATH6 code (Pollock, 2012), to calculate the age distribution of groundwater discharge to existing and hypothetical (seeded) glacial wells; and

- anticipated use of the inset models as a training area for statistical modeling of groundwater age at glacial wells through the development of predictor variables and age metrics that distill the input and output of the applied inset models and whose correlation structures capture the physics inherent within the inset models.

The development of appropriate inset flow models and predictor variables is a crucial and difficult step in the metamodeling process. Because of the complexity of the effort, this entire report is devoted to work that is preliminary to future statistical modeling.

\section{Description of Study Area}

The domain of the LMB model (Feinstein and others, 2010), the parent of the inset models, extends over parts of five states in the upper Midwest (fig. 1). The five inset models fall within the nearfield portion of the LMB model where the parent cell size is square and uniformly 5,000 feet ( $\mathrm{ft}$ ) on a side. The nearfield of the LMB model domain corresponds to the principal area of interest in which the hydrogeology is well defined. The nearfield is enclosed by the farfield of the LMB model domain, which incorporates less detail and functions effectively as a boundary condition for the nearfield.

The inset models within the LMB model nearfield are each centered on a drainage basin (watershed) corresponding to HUC8 basins, that is 8-digit hydrologic units as defined in the U.S. Geological Survey Watershed Boundary Dataset (U.S. Geological Survey, 2016). A hydrologic unit is a drainage basin delineated to nest within a multi-level hierarchical drainage system. In the upper Midwest, HUC8 basins correspond to the drainage area of major rivers; they are typically between 1,000 and 2,000 square miles in total area.

The target HUC 8 basins within in the inset model domains (fig. 2) are

- the Kalamazoo basin in the Lower Peninsula of Michigan (hydrologic unit code [HUC] 04050003),

- the Boardman-Charlevoix basin in the Lower Peninsula of Michigan (HUC 04060105),

- the Upper Fox basin in northeastern Illinois (HUC 07120006),

- the Manitowoc-Sheboygan basin in eastern Wisconsin (HUC 04030101), and

- the combined Tacoosh-Whitefish and FishdamSturgeon basins in the Upper Peninsula of Michigan (HUC 04030111 and HUC 04030112, respectively).

All five of the HUC8 basins share a similar hydrostratigraphic setting as described in detail in Feinstein and others, 2010. This setting consists of unconsolidated glacial deposits (with some alluvial material) over sedimentary bedrock. The thickness of the glacial material across the basins varies from near zero (Whitedam basin) to $1,000 \mathrm{ft}$ (Board basin). The relative proportion of groundwater that circulates in the glacial as opposed to the bedrock parts of the flow system varies from basin to basin and within individual basins.

The HUC8 basins were chosen to sample areas east, west, and north of Lake Michigan. These areas correspond to a variety of climatic, land-use, and hydrogeologic conditions present in the upper Midwest (Feinstein and others, 2010, section 1). All the basins are tributary to Lake Michigan except the Upper Fox, which is in the Mississippi River Basin just west of the Lake Michigan topographic divide. Small parts of the Boardman-Charlevoix and Tacoosh-Whitefish HUC8 basins, which are only narrowly connected to their main areas, are excluded from the inset model basins for convenience in extracting the 


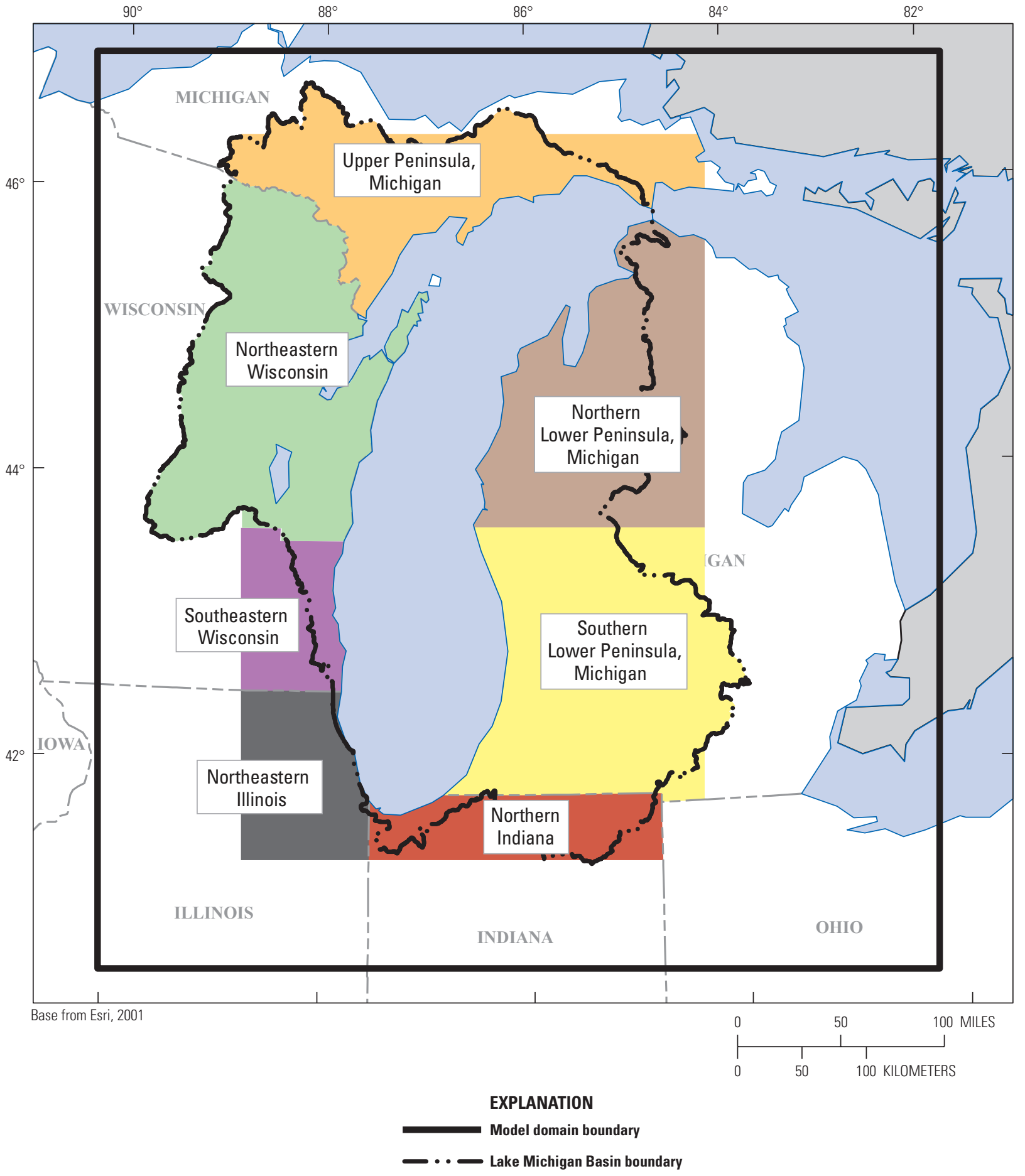

Figure 1. Lake Michigan Basin MODFLOW model domain. Modified from Feinstein and others, 2010. 


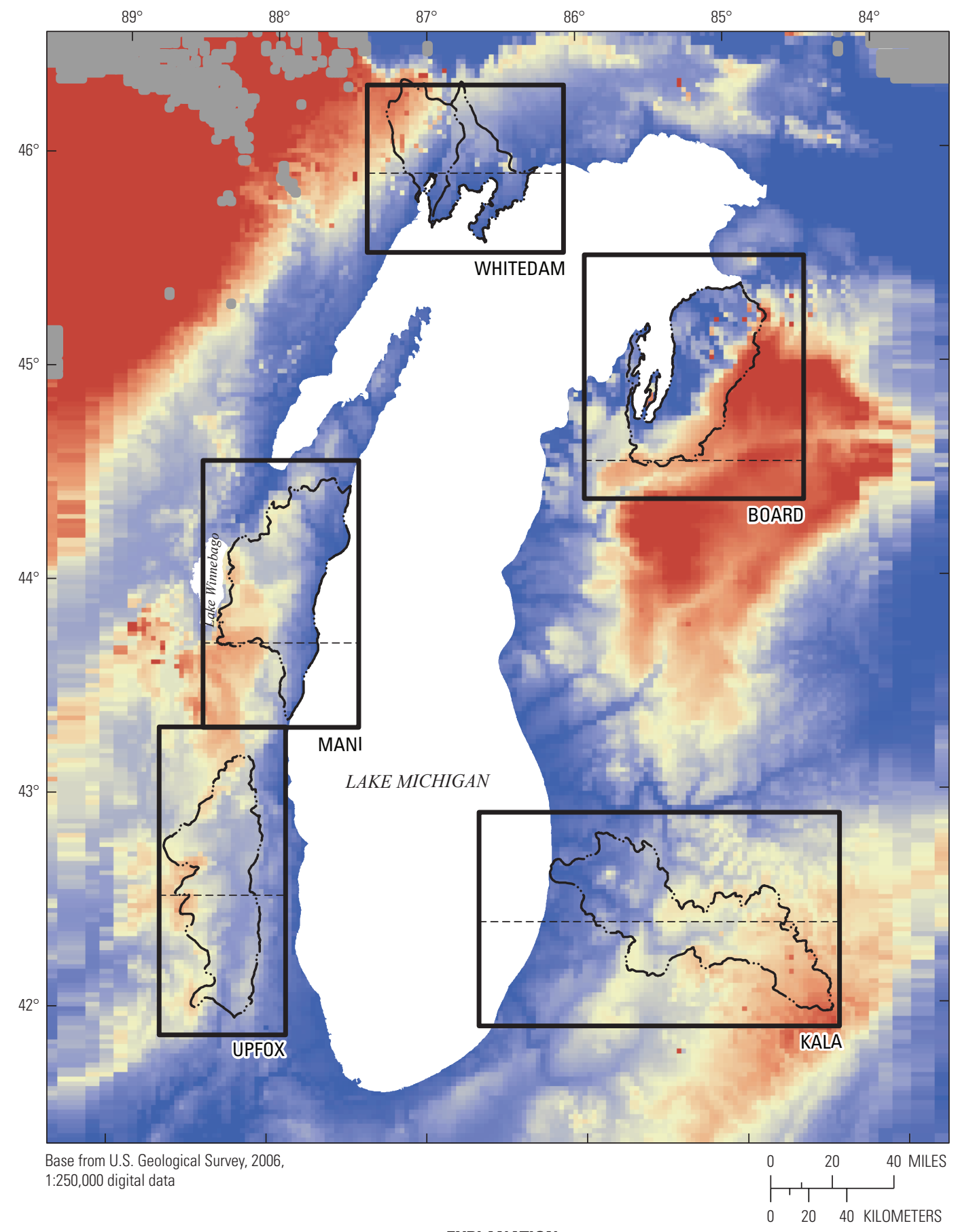

\section{EXPLANATION}

Simulated 2005 water table elevation, in feet above NGVD 29
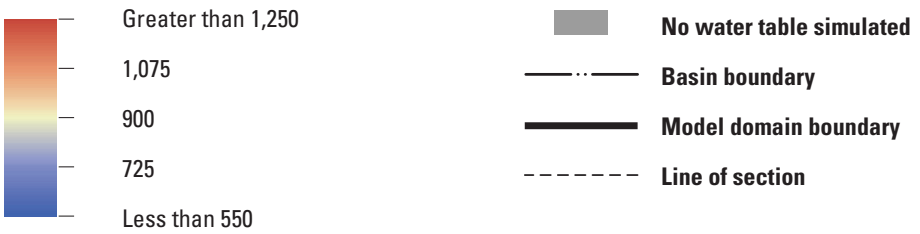

Figure 2. Location of inset MODFLOW model domains superimposed on simulated 2005 water table for Lake Michigan Basin model (unconfined version). Dotted lines show cross sections contained in figure 5. 
inset models from the parent model. The omitted areas do not affect the objectives of this study - the assembly of predictors and outcomes related to the age of shallow well discharge.

\section{Parent Lake Michigan Basin Model}

The five inset models are derived from a parent groundwater flow model centered on LMB (Feinstein and others, 2010). The LMB model (parent model) was developed to support the Great Lakes Basin Pilot project under the U.S. Geological Survey National Water Availability and Use Program. The LMB model is based on multiple databases that have been assembled from many sources to represent water use, glacial stratigraphy, bedrock stratigraphy, salinity, recharge, and the surface-water network (discussed in Feinstein and others, 2010). The transient 2-million-cell LMB model incorporates multiple aquifers and pumping centers. It simulates the exchange between a dense surface-water network and heterogeneous glacial deposits overlying stratified bedrock in the Lower and Upper Peninsulas of Michigan, eastern Wisconsin, northern Indiana, and northeastern Illinois. The model is used to quantify changes in the groundwater system in response to pumping and variations in recharge from 1864 to 2005. Model results quantify the sources of water to major pumping centers, illustrate the dynamics of the groundwater system, and yield measures of water availability useful for water-resource management in the region.

The LMB model incorporates stress conditions (recharge and pumping) that vary over time as a function of land-use, climate, and water-use changes (Feinstein and others, 2010). The inset models presented in this study were constructed using the recharge and pumping conditions for the final 2001-5 stress period of the parent unconfined version of the LMB model.

In order to better represent the configuration of the stream network and simulate local groundwater/surface-water interactions, an alternative version of the LMB model was recently produced (Feinstein and others, 2016). The alternative version imposed a refined 500-ft lateral spacing in the topmost layer of the model to better capture the stream contribution to shallow groundwater pumping and was used to support a metamodel of the source of water to shallow wells (Fienen and others, 2016). The inset models presented in this study share the same 500 -ft lateral spacing as the alternative version of the LMB model. The models also incorporate the surface-water network corresponding to its refined grid spacing. More details on the various inputs to the inset models are provided further on in this report.

\section{Abbreviations Adopted for this Report}

The model, HUC8, and stratigraphic unit abbreviations used in this report are listed in table 1. Kalamazoo, BoardmanCharlevoix, Upper Fox, Manitowoc-Sheboygan, and TacooshWhitefish/Fishdam-Sturgeon HUC8 basins are referred to as the KALA, BOARD, UPFOX, MANI and WHITEDAM basins, respectively. The GLAC or glacial units incorporate all Quaternary deposits within the inset model domains, whether they are of glacial or alluvial origin. These deposits are unlithified, in contrast to the lithified sedimentary rocks that make up the bedrock units.

\section{Extraction of Inset Models from Parent Lake Michigan Basin Model}

The LMB model incorporates a large area in the upper Midwest with diverse glacial settings (Feinstein and others, 2010). For this reason, it is a good starting point for identifying and sampling hydrogeologic conditions that affect the groundwater age of shallow well water. However, the 5,000 by $5,000-\mathrm{ft}$ grid spacing of this regional model is too coarse to reliably capture mechanisms, such as the interaction between shallow wells and nearby surface water (Feinstein and others, 2016), or the effects of glacial heterogeneity on the direction and duration of pathlines (Feinstein and others, 2012). To overcome the limits imposed by the regional grid spacing, inset models have been extracted from five areas of the LMB domain to simulate groundwater flow conditions in different glacial settings at a much refined grid spacing, thereby allowing more precise location of wells, more precise location of surface-water features, and more detailed representation of heterogeneous glacial deposits. The added precision in the inset models is intended to strengthen the functional relations controlling the simulated time of groundwater travel to shallow wells. In summary, inset model refinement has been undertaken to improve the ability of a future statistical model, emulating process-based flow models, to identify the controls on groundwater age in shallow well discharge.

A telescopic mesh refinement technique (Rumbaugh and Rumbaugh, 2011) has been applied to the parent LMB model to extract and modify five inset models for the domains shown in figure 2. The technique consists of two steps. First, the lateral grid spacing of square cells is refined from the original size of $5,000 \mathrm{ft}$ on a side to $500 \mathrm{ft}$ on a side. In the vertical direction, however, the LMB layer spacing is not refined. Consequently, each cell in the LMB model now corresponds to 100 cells in the inset models. Second, the edge boundary conditions of the inset models are set to constant head conditions derived from the LMB model. The head values corresponding to the nodes at the center of the cells of the LMB model at the 5,000-ft spacing are linearly interpolated to generate the constant head cells at the nodes of the inset models at the $500-\mathrm{ft}$ spacing.

The inset models vary by size and dimension (table 2). However, each inset model is centered on a single or, in the case of the WHITEDAM model, two HUC8 basins. In the WHITEDAM model, the northern-most part of the eastern HUC8 basin (Fishdam-Sturgeon) is excluded from the inset model domain because it was not part of the nearfield of the parent LMB model (fig. 2). 
Table 1. Abbreviations used in this report.

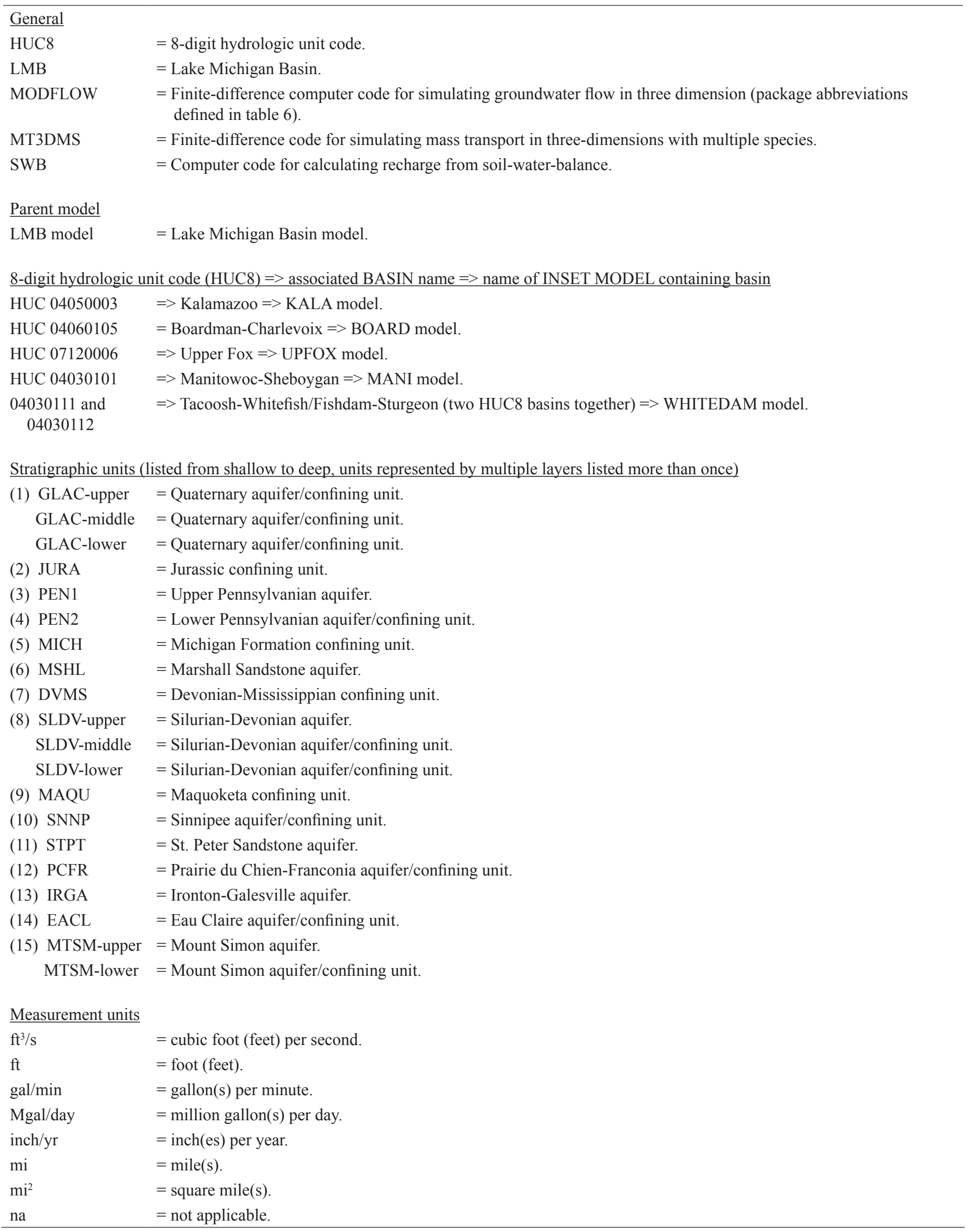




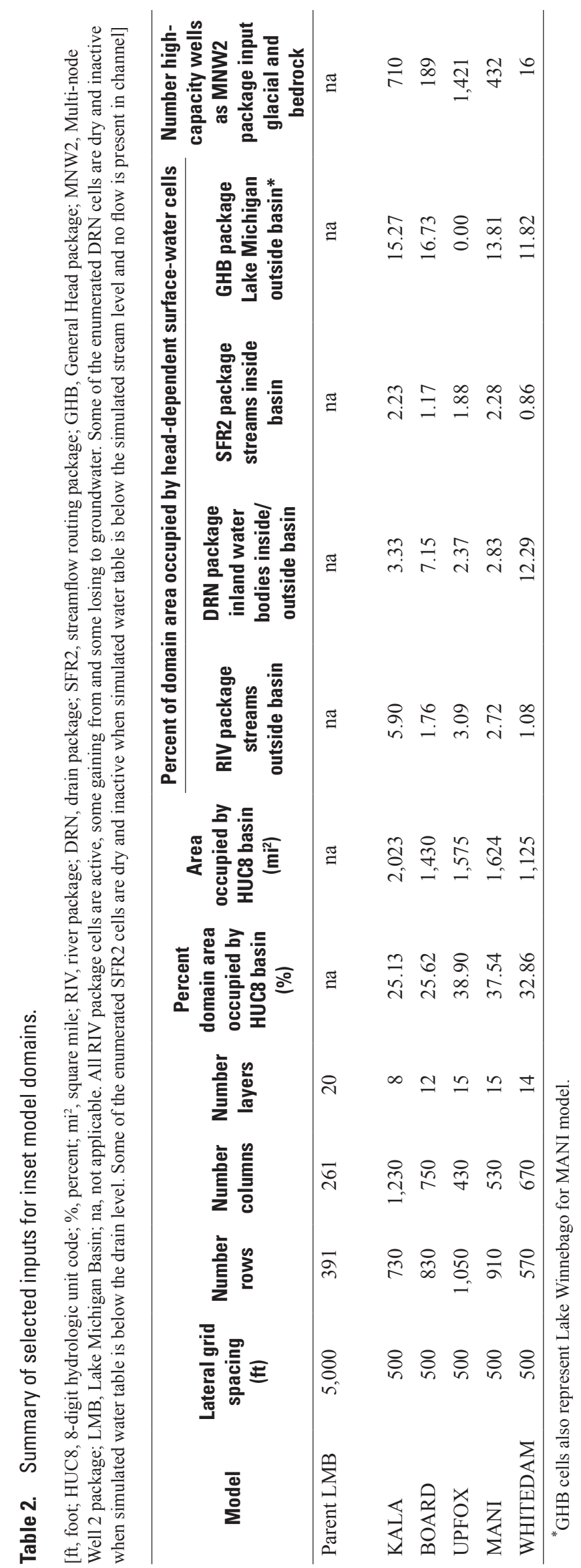


Two versions of the parent LMB model are available at the 5,000-ft spacing. The first version incorporates confined aquifer conditions everywhere, and the second allows unconfined aquifer conditions where the simulated water level is below the top of a cell volume (Feinstein and others, 2010, section 7.1). All the inset models are extracted from the unconfined version of the LMB model. In particular, the constant heads assigned to the boundary conditions of the inset models were extracted from this version of the LMB model. The 2005 water table simulated by the unconfined version of the LMB model is shown with the inset model domains in figure 2 . The constant head values for the top layer of each inset model correspond to the intersection of the inset model domain boundaries in figure 2. The same mapping process from the parent model to the inset models occurs for the deeper layers. That is, the lateral boundary conditions assigned to all layers at the edges of each inset model correspond to the coincident heads simulated by the parent model, with appropriate linear interpolation to account for the finer grid spacing in the inset models relative to the LMB model.

All constant head values for the KALA, BOARD, UPFOX, MANI, and WHITEDAM inset models are derived from the 2005 simulation using the unconfined version of the LMB model. These head values reflect the recharge and pumping conditions input to the LMB model for the 2001-5 stress period. By definition, the constant head values transferred to the inset models do not respond to new stresses added to the inset models (for example, hypothetical wells). The study area for each inset model is the HUC8 basin it encloses. In order to minimize the boundary effect of constant heads on the inset model solutions within each study area, areas outside the HUC8 basins have been added to the inset model domains. On average the HUC8 basins occupy only about one-third of the total inset model area (table 2). Typically, more than one shallow groundwater divide is present between the HUC8 basin boundary and the edge of an inset model. The distance of the basins from the inset model edges serves to insulate the head and flux solutions within the study areas from the unchanging constant head edge boundary conditions even if new stresses are applied to the shallow glacial deposits within the target HUC8 basins.

\section{Inset Model Properties Inherited from the Parent Lake Michigan Basin Model}

\section{Boundary Conditions for Edge Cells and for Lake Michigan}

The boundary conditions for the inset models include the constant head values assigned to all layers at the edge of the inset models, which allow water to pass into and out of the inset model domains, and boundary conditions internal to each domain, which act as sources and sinks for groundwater. The biggest sink is Lake Michigan, which is represented by MODFLOW general head boundaries (table 2). All Lake Michigan cells are assigned a water level (general head) of $577.5 \mathrm{ft}$ (all elevations are referenced to the National Geodetic Vertical Datum of 1929), corresponding to the lake's low-water level. The lakebed conductance inherited from the parent model was set to 250,000 square feet per day $\left(\mathrm{ft}^{2} / \mathrm{d}\right)$ for all KALA, BOARD, MANI, and WHITEDAM lake cells, corresponding to a vertical hydraulic conductivity value of 1 foot per day ( $\mathrm{ft} / \mathrm{d}$ ) for a nominal bed thickness of $1 \mathrm{ft}$ and for a uniform cell area of 250,000 square feet $\left(\mathrm{ft}^{2}\right)$. These values reflect the assumed silty texture of the lakebed. The lake cells generally are assigned to layer 1 but sometimes to deeper layers when the lakebed is in bedrock. In the MANI model a general head boundary condition is also assigned to a large inland water body, Lake Winnebago (fig. 2). All Lake Winnebago cells share a conductance value of $500,000 \mathrm{ft}^{2} / \mathrm{d}$ and a lake water level equal to $747 \mathrm{ft}$. Because the eastern boundary of the UPFOX model is set just west of the Lake Michigan shoreline, it does not include any general head cells.

The locations of the constant head and general head boundaries are shown for each inset in figures $3 A-E$. Both of these boundary conditions can act as either sources or sinks for groundwater. However, given that Lake Michigan is the sink for the regional flow system, its cells typically accept groundwater discharge along the shoreline.

\section{Water Use}

Shallow and deep pumping in the Lake Michigan Basin and surrounding areas is a major stress on the groundwater system over much of the domain, causing cones of depression to form around pumping centers and groundwater divides to migrate from natural conditions. The construction of the LMB model required the assembly of a large database devoted to groundwater pumping between 1864 and 2005 from high-capacity public-supply, irrigation, and industrial wells (Buchwald and others, 2010; Feinstein and others, 2010, section 4.7). High-capacity wells are defined as those that are permitted to extract more than 70 gallons per minute (gal/min; 100,000 gallons/day); domestic wells typically extract less.

The inset models inherited the locations and pumping rates of high-capacity wells from the final 2001-5 stress period of the LMB model. The water budget from the base simulation of each inset model incorporates the withdrawals from these existing wells, some of which are from the glacial deposits and some of which are from bedrock aquifers. The distribution of glacial pumping rates for the existing glacial wells is shown, by inset model, in figures $3 A-E$. The numbers of glacial and bedrock existing wells, by inset model, are listed in table 2. All existing wells act as sinks for groundwater, except for a few glacial injection wells within the KALA model domain. 


\section{A. KALA}

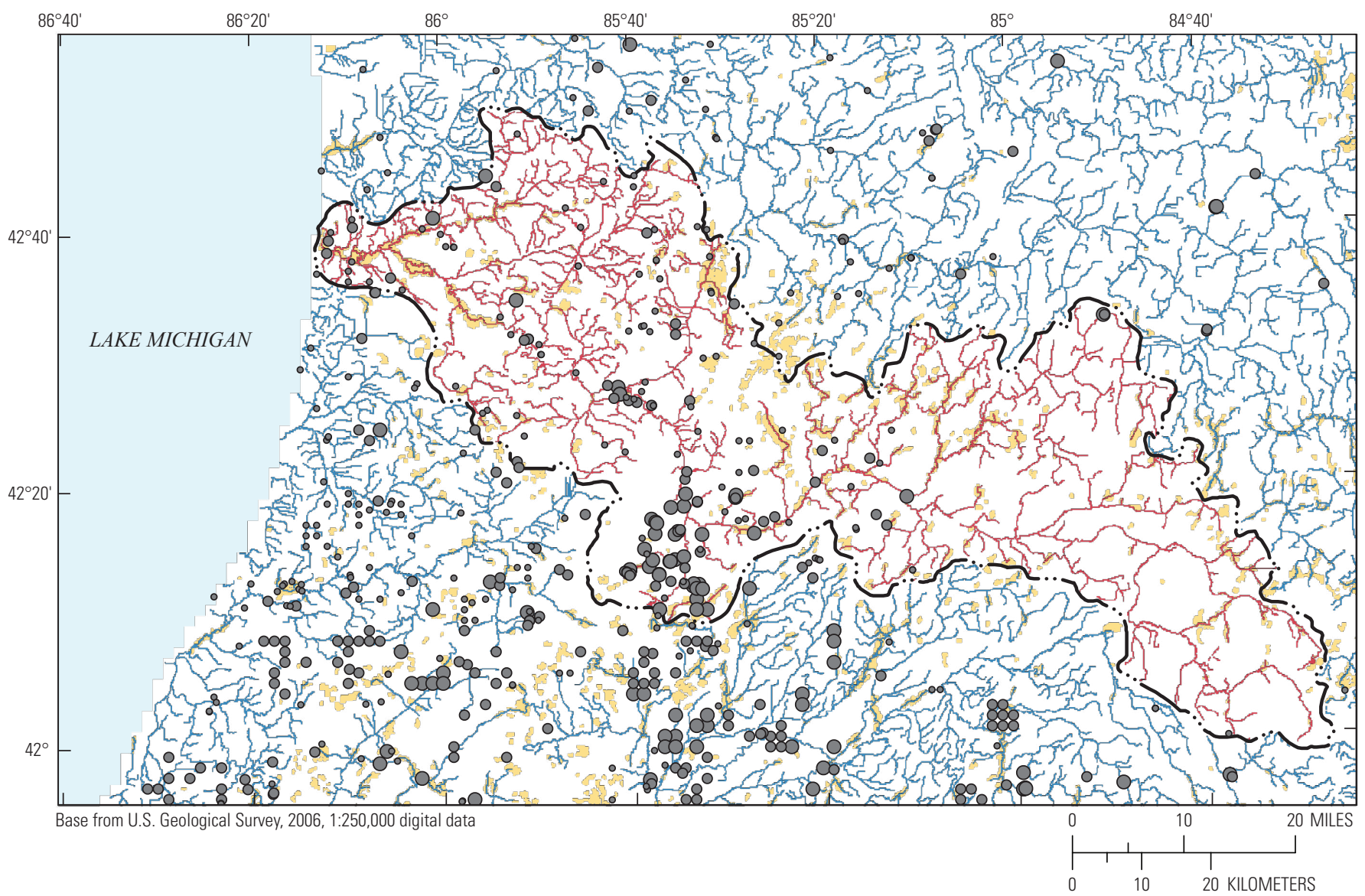

\section{EXPLANATION}

Stream (SFR2 package) cells representing active and inactive streams in the KALA basin

Drain (DRN package) cells representing active and inactive water bodies in the model

Constant head cells representing water levels at the edge of the model grid

General Head Boundary (GHB package) cells representing Lake Michigan

River (RIV package) cells representing streams outside the KALA basin

-... KALA basin boundary

Glacial wells with pumping rate, in gallons per minute

- $\quad 0-50$

○ 51-250

Greater than 250

Figure 3. Boundary conditions for inset models $A$, KALA; $B, \mathrm{BOARD}$; $C$, UPFOX; $D$, MANI; and $E$, WHITEDAM. 
B. BOARD

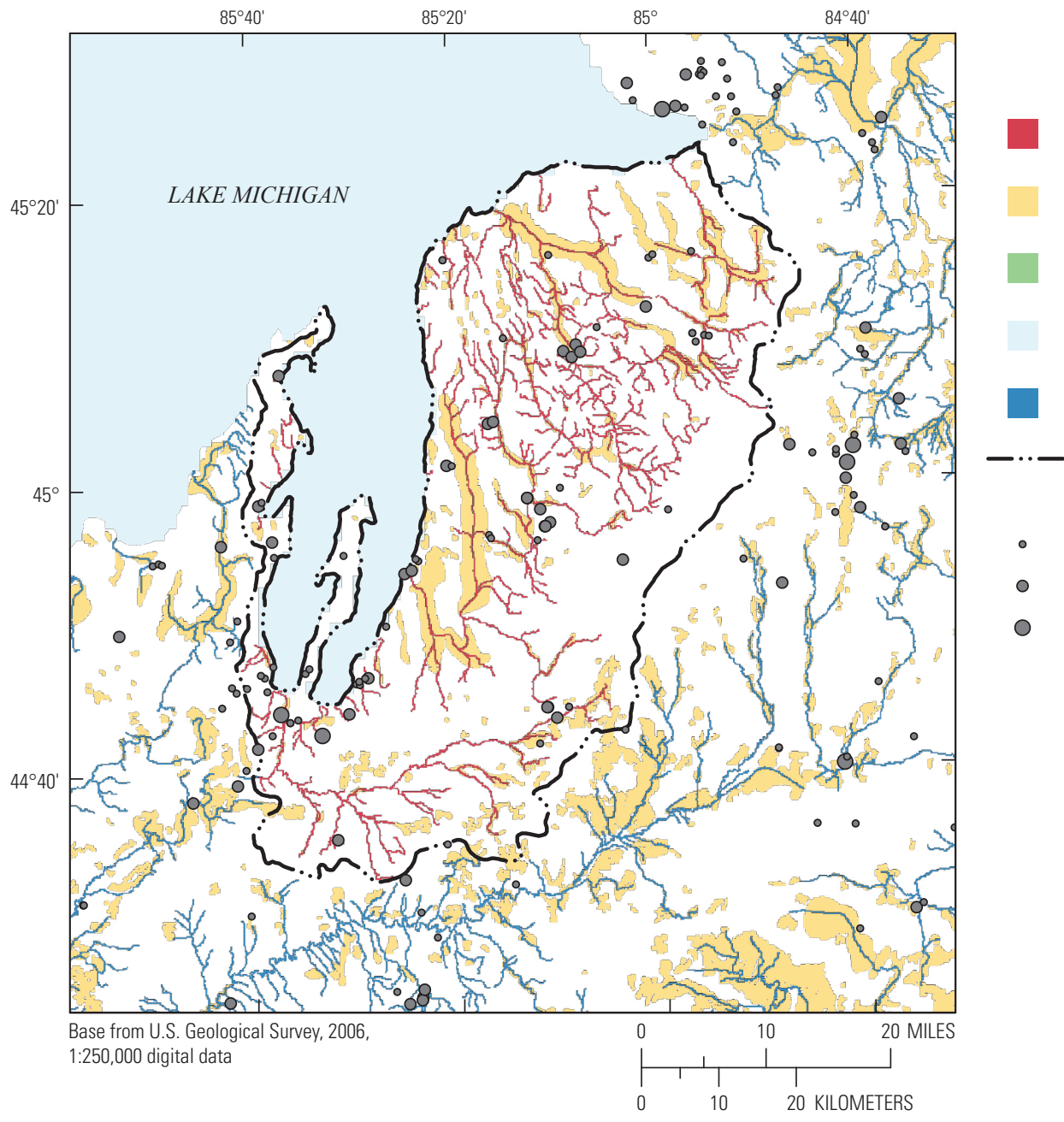

\section{EXPLANATION}

Stream (SFR2 package) cells representing active and inactive streams in the BOARD basin

Drain (DRN package) cells representing active and inactive water bodies in the model

Constant head cells representing water levels at the edge of the model grid

General Head Boundary (GHB package) cells representing Lake Michigan

River (RIV package) cells representing streams outside the BOARD basin

BOARD basin boundary

Glacial wells with pumping rate, in gallons per minute $0-50$

$51-250$

Greater than 250

Figure 3. Boundary conditions for inset models $A, \mathrm{KALA} ; B$, BOARD; $C$, UPFOX; $D$, MANI; and E, WHITEDAM. - Continued 
C. UPFOX

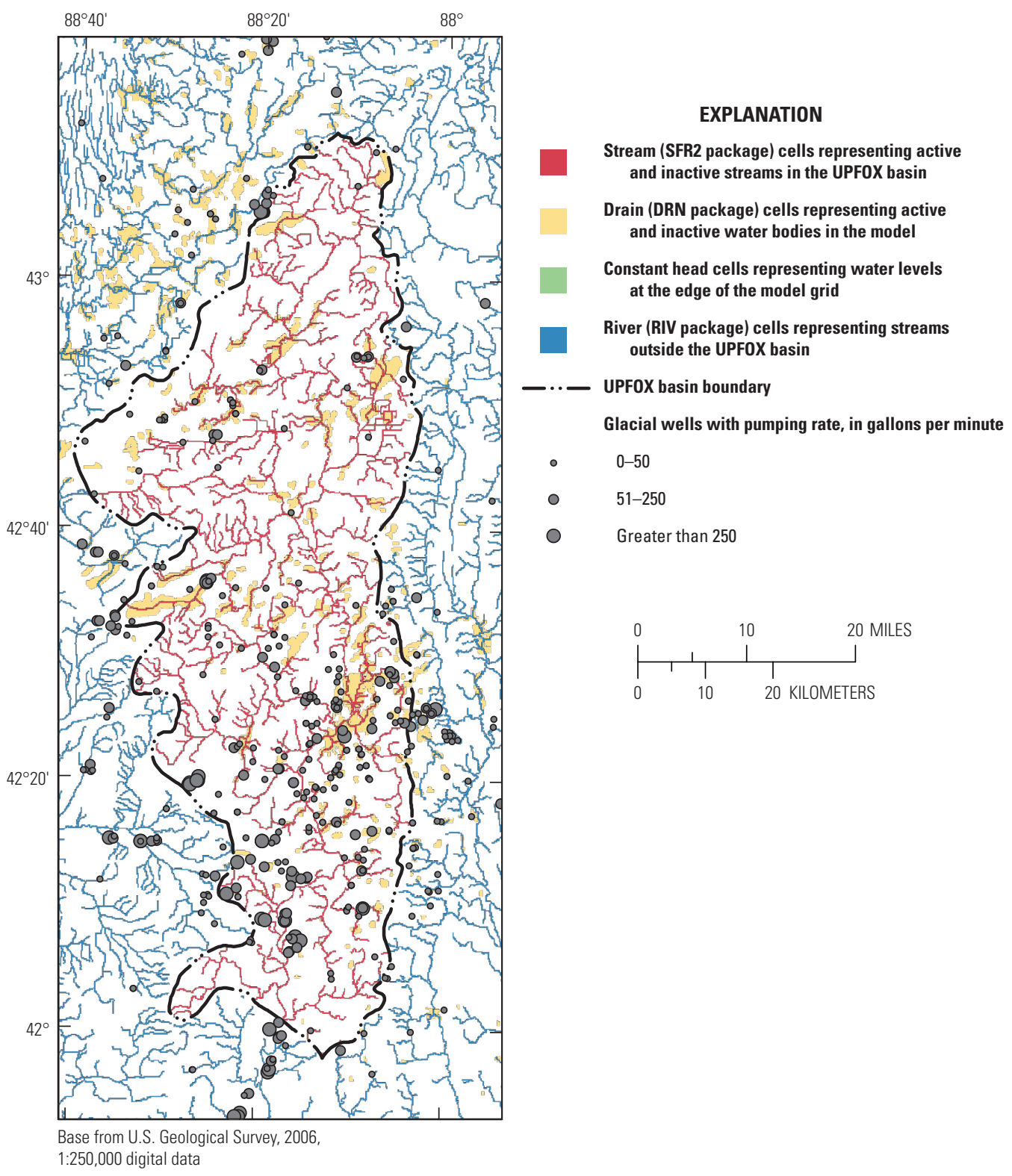

Figure 3. Boundary conditions for inset models $A, \mathrm{KALA} ; B, \mathrm{BOARD} ; C$, UPFOX; $D, \mathrm{MANl}$; and E, WHITEDAM.-Continued 


\section{MANI}

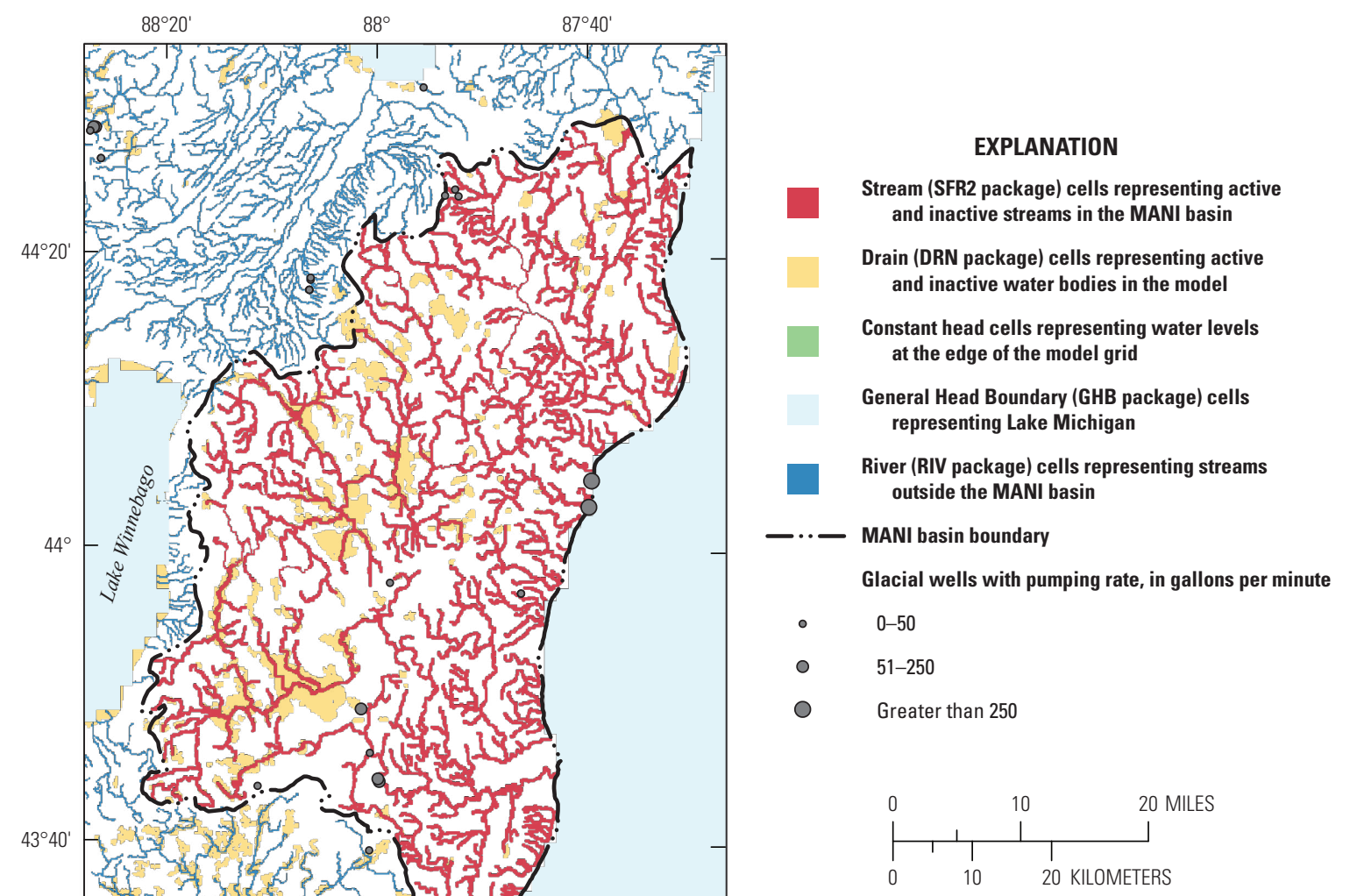

Figure 3. Boundary conditions for inset models $A, K A L A$; $B$, BOARD; $C$, UPFOX; $D$, MANI; and E, WHITEDAM.-Continued

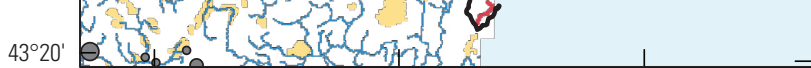

Base from U.S. Geological Survey, 2006,

1:250,000 digital data
LAKE MICHIGAN

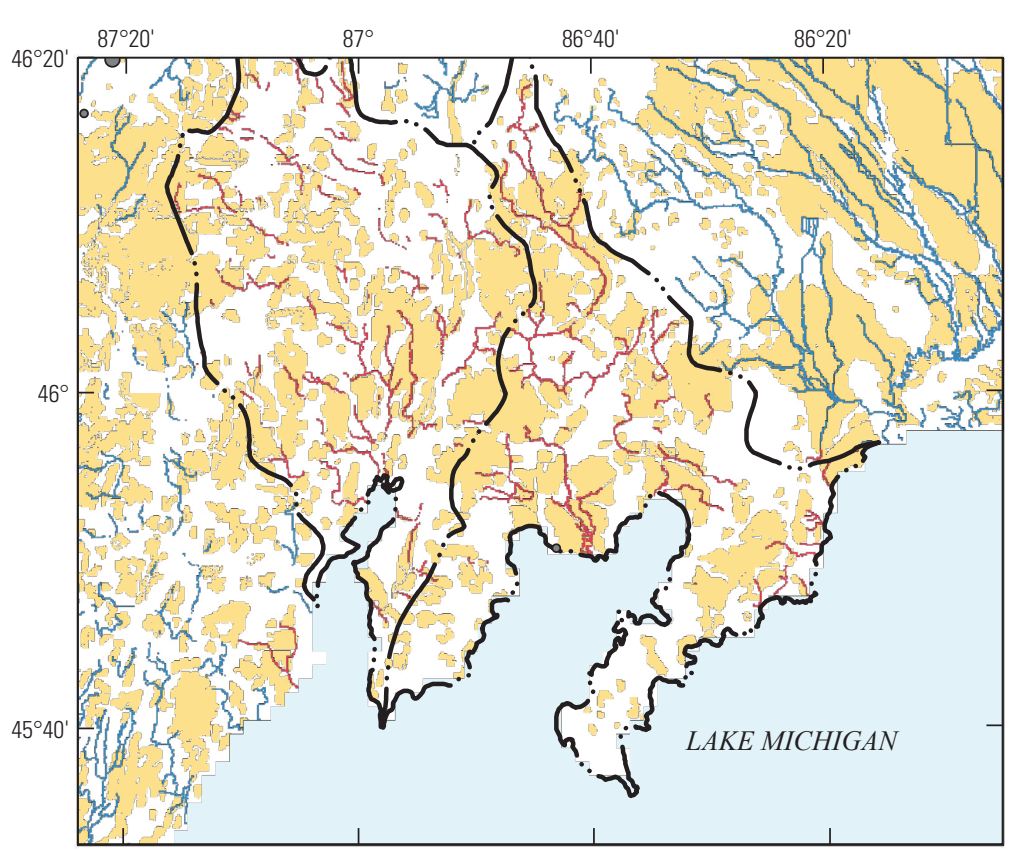

Base from U.S. Geological Survey, 2006,

1:250,000 digital data

\section{EXPLANATION}

Stream (SFR2 package) cells representing active and inactive streams in the WHITEDAM basin

Drain (DRN package) cells representing active and inactive water bodies in the model

Constant head cells representing water levels at the edge of the model grid

General Head Boundary (GHB package) cells representing Lake Michigan

River (RIV package) cells representing streams outside the WHITEDAM basin

—..- WHITEDAM basin boundary

Glacial wells with pumping rate, in gallons per minute

- $\quad 0-50$

○ $\quad 51-250$

- Greater than 250

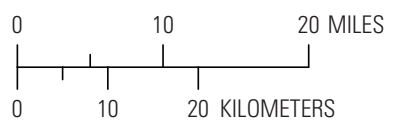




\section{Hydrostratigraphy, Layering, and Bedrock Transmissivity}

The scheme for mapping hydrostratigraphic units in the upper Midwest in the LMB model layers is laid out in detail in Feinstein and others (2010, section 2.2) and is presented graphically in figure 4 . The 20 layers of the parent model correspond to 15 hydrostratigraphic units. A listing of units with abbreviations is given in table 1 . The top three layers correspond to the youngest unit of Quaternary age. The Quaternary unit incorporates all unlithified deposits and is associated with deposits mainly of glacial origin, along with some alluvium mostly in stream valleys. The remaining 14 units are all sedimentary rocks, spanning geologic periods from the Jurassic (youngest) to Cambrian (oldest). Each bedrock unit corresponds to one model layer, except for the Silurian-Devonian aquifer (3 layers) and the Mount Simon aquifer at the bottom of the sedimentary sequence (2 layers). The Precambrian rocks that underlie the Mount Simon are largely crystalline in composition and generally exhibit low permeability. The top of the Precambrian rocks is taken as a bottom no-flow boundary for the LMB model.

The LMB model layering scheme was transferred to the derived inset models. This scheme extends from the glacial deposits to the boundary between the Cambrian-Ordovician and underlying Precambrian rocks. However, in each inset model certain layers were omitted. In the case of the inset domains east of Lake Michigan, some lower bedrock layers were omitted because their groundwater flux simulated by the parent LMB model was very small relative to the flux in overlying layers. For the KALA model domain, the upward flow from layers below the Marshall Sandstone (that is, below layer 8 in the parent LMB model) represents only 0.040 percent of the inflow simulated by the LMB model to the shallower layers; therefore, a no-flow boundary was imposed at the bottom of the Marshall Sandstone. For the BOARD model domain, the upward flow from below the Silurian-Devonian aquifer (that is, below layer 12 in the parent LMB model) represents only 0.015 percent of the inflow simulated by the LMB model to the shallower layers; therefore, a no-flow boundary was imposed at the bottom of the Silurian-Devonian aquifer. In the case of inset models for domains west or north of Lake Michigan, the deep bedrock units participate more actively in overall groundwater circulation; therefore, the bottoms of these inset models are the same as in the parent LMB model, equivalent to the top of the Precambrian rocks. However, some of the shallower units are absent from the hydrostratigraphic section within the inset model domains, although they form part of the stratigraphic section elsewhere in the LMB model domain. In the LMB model, the units that are present in only part of the domain are given a "pinched" thickness of $0.2 \mathrm{ft}$ where stratigraphically absent. However, if the unit is entirely absent from the domain of an inset model, there is no point in maintaining it as part of the layer sequence. For the UPFOX and MANI models, the absent and omitted shallow bedrock layers are of Jurassic through Mississippian age, corresponding to layers 4 through 8 in the LMB model. For the WHITEDAM model, the absent and omitted shallow bedrock layers extend from the Jurassic through the Devonian in age, corresponding to layers 4 through 9 in the LMB model. The configuration of included and omitted bedrock units for all the inset models is summarized in table $3 \mathrm{~A}$.

The vertical cross sections in figures $5 A-E$ show the thickness of units for each inset model along a selected eastwest cross section (the lines of section are shown in fig. 2). Two plots are presented for each inset model —one without and one with vertical exaggeration. The former shows the actual ratio of the horizontal and vertical dimensions of the modeled flow system along the cross section (demonstrating how much the horizontal dimension dominates in these groundwater systems). The latter renders more evident the elevation and thickness trends of the various units. In particular, the sections in figure 5 show the representative thickness of the unlithified Quaternary (glacial) deposits in the top three model layers relative to the thickness of the underlying bedrock layers. The unlithified deposits are thickest in the BOARD model and thinnest in the WHITEDAM model.

For the purposes of this study, the stratigraphic scheme that the inset models inherited from the parent LMB model is particularly important for the layers containing the unlithified deposits, hereinafter referred to as the "glacial" layers. The layering logic for the glacial layers is explained in three statements.

- Layer 1 extends from land surface to a maximum depth of $100 \mathrm{ft}$; if the bottom of the glacial deposits is at a depth less than $100 \mathrm{ft}$ below land surface, then the bottom of layer 1 is at that depth.

- If the glacial thickness is greater than $100 \mathrm{ft}$, then layer 2 extends from the $100-\mathrm{ft}$ depth to a maximum depth of $300 \mathrm{ft}$; otherwise layer 2 is pinched.

- If the glacial thickness is greater than $300 \mathrm{ft}$, then layer 3 extends from the $300-\mathrm{ft}$ depth to top of bedrock; otherwise layer 3 is pinched.

Pinched cells were assigned a thickness of $0.2 \mathrm{ft}$ and given the properties of the overlying layers. The number and percentage of pinched cells in glacial layers for the entire inset model domains are compiled in table $3 B$. Pinched glacial cells were assigned the horizontal and vertical hydraulic conductivity of the unpinched cells above them. If all three layers are pinched (that is, glacial deposits are absent in a cell), then the aquifer properties are derived from the underlying bedrock. Given the negligible thickness of the pinched cells, they have virtually no effect on the inset model results.

In some areas of the LMB model domain, sedimentary rocks are at or very near the land surface. In those parts of the inset models (see fig. 6), the three glacial layers are treated as no-flow cells and are rendered inactive during the simulations. 


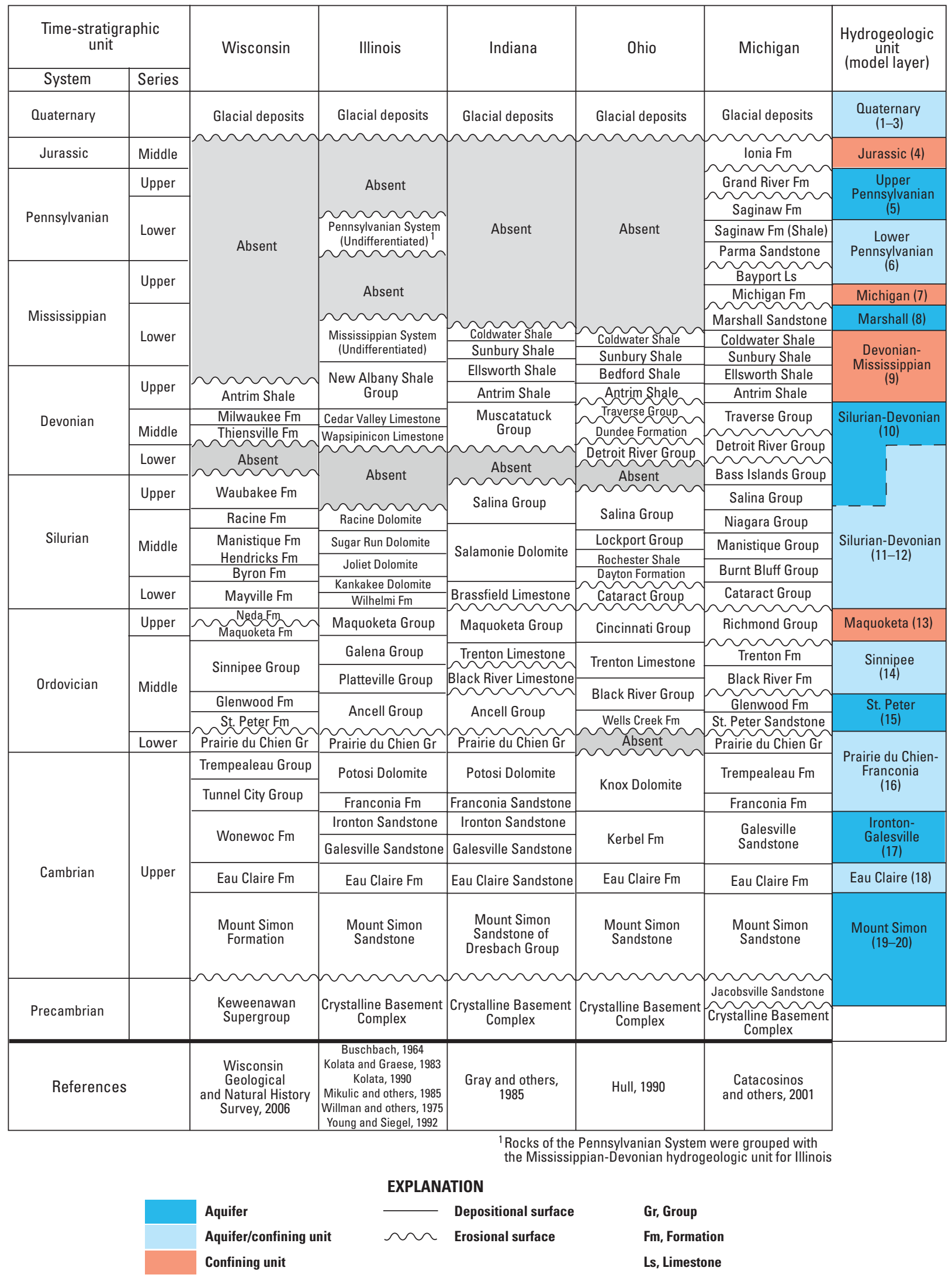

Figure 4. Composite hydrostratigraphic section for Lake Michigan Basin model. Modified from Feinstein and others, 2010. 
Table 3. Status of model layers and units. $A$, units associated with bedrock layers of inset models and $B$, pinched cells in glacial layers.

\section{A. Units associated with bedrock layers of inset models}

[Absent, signifies that the unit is not present and, therefore, omitted from inset model domain; $\mathrm{X}$, signifies that bedrock unit is present and included in inset model domain; Little exchange, signifies that the unit is omitted from inset model domain because there is little groundwater exchange with overlying layers. See table 1 for unit abbreviations. Model columns arranged from west to east]

\begin{tabular}{|c|c|c|c|c|c|c|}
\hline Bedrock unit & Number layers & UPFOX & MANI & WHITEDAM & BOARD & KALA \\
\hline JURA confining unit & 1 & Absent & Absent & Absent & $\mathrm{X}$ & $\mathrm{X}$ \\
\hline PEN1 aquifer & 1 & Absent & Absent & Absent & $\mathrm{X}$ & $\mathrm{X}$ \\
\hline MICH confining unit & 1 & Absent & Absent & Absent & $\mathrm{X}$ & $\mathrm{X}$ \\
\hline MSHL aquifer & 1 & Absent & Absent & Absent & $X$ & $\mathrm{X}$ \\
\hline SLDV aquifer/confining unit & 3 & $\mathrm{X}$ & $\mathrm{X}$ & $\mathrm{X}$ & $\mathrm{X}$ & Little exchange \\
\hline MAQU confining unit & 1 & $\mathrm{X}$ & $\mathrm{X}$ & $\mathrm{X}$ & Little exchange & Little exchange \\
\hline SNNP aquifer confining unit & 1 & $\mathrm{X}$ & $\mathrm{X}$ & $\mathrm{X}$ & Little exchange & Little exchange \\
\hline STPT aquifer & 1 & $\mathrm{X}$ & $\mathrm{X}$ & $\mathrm{X}$ & Little exchange & Little exchange \\
\hline PCFR aquifer/confining unit & 1 & $X$ & $\mathrm{X}$ & $X$ & Little exchange & Little exchange \\
\hline
\end{tabular}

\section{B. Pinched cells in glacial layers}

[A pinched cell is less than $0.2 \mathrm{ft}$ thick. Thickness is full thickness, not saturated thickness. In each model layer 1 represents up to the top $100 \mathrm{ft}$ thickness of glacial deposits from land surface; layer 2 represents 100 to $300 \mathrm{ft}$ depth of glacial deposits (if glacial thickness not greater than $100 \mathrm{ft}$, layer 2 is pinched); layer 3 represents depths of glacial deposits greater than $300 \mathrm{ft}$ (if glacial thickness not greater than $300 \mathrm{ft}$, layer 3 is pinched)]

\begin{tabular}{|c|c|c|c|c|}
\hline Inset model & Layer & Number cells & Number pinched & Percent pinched \\
\hline \multirow[t]{2}{*}{ KALA } & 1 & 897,900 & 40 & 0.0045 \\
\hline & 2 & 897,900 & 321,573 & 35.81 \\
\hline \multirow[t]{2}{*}{ BOARD } & 1 & 622,500 & 400 & 0.0643 \\
\hline & 3 & 622,500 & 271,790 & 43.66 \\
\hline \multirow[t]{3}{*}{ UPFOX } & 1 & 451,500 & 498 & 0.1103 \\
\hline & 2 & 451,500 & 108,232 & 23.97 \\
\hline & 3 & 451,500 & 426,329 & 94.43 \\
\hline \multicolumn{5}{|l|}{ MANI } \\
\hline & 2 & 482,300 & 242,807 & 50.34 \\
\hline & 3 & 482,300 & 467,283 & 96.89 \\
\hline \multicolumn{5}{|l|}{ WHITEDAM } \\
\hline & 1 & 381,900 & 15,756 & 4.126 \\
\hline & 2 & 381,900 & 339,833 & 88.98 \\
\hline & 3 & 381,900 & 372,499 & 97.54 \\
\hline
\end{tabular}




\section{A. KALA, row 370}
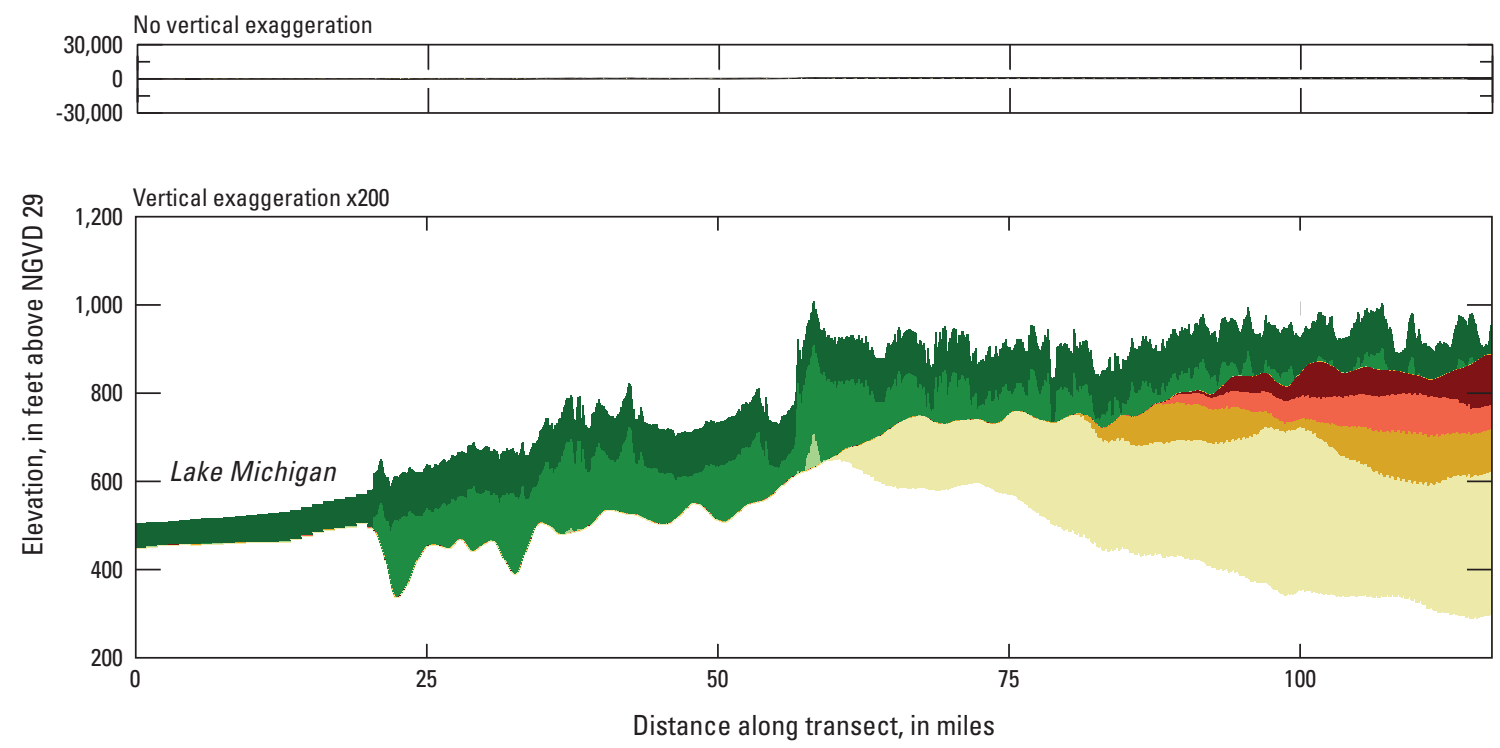

\section{EXPLANATION}

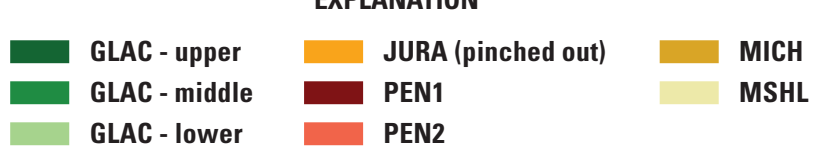

B. BOARD, row 700
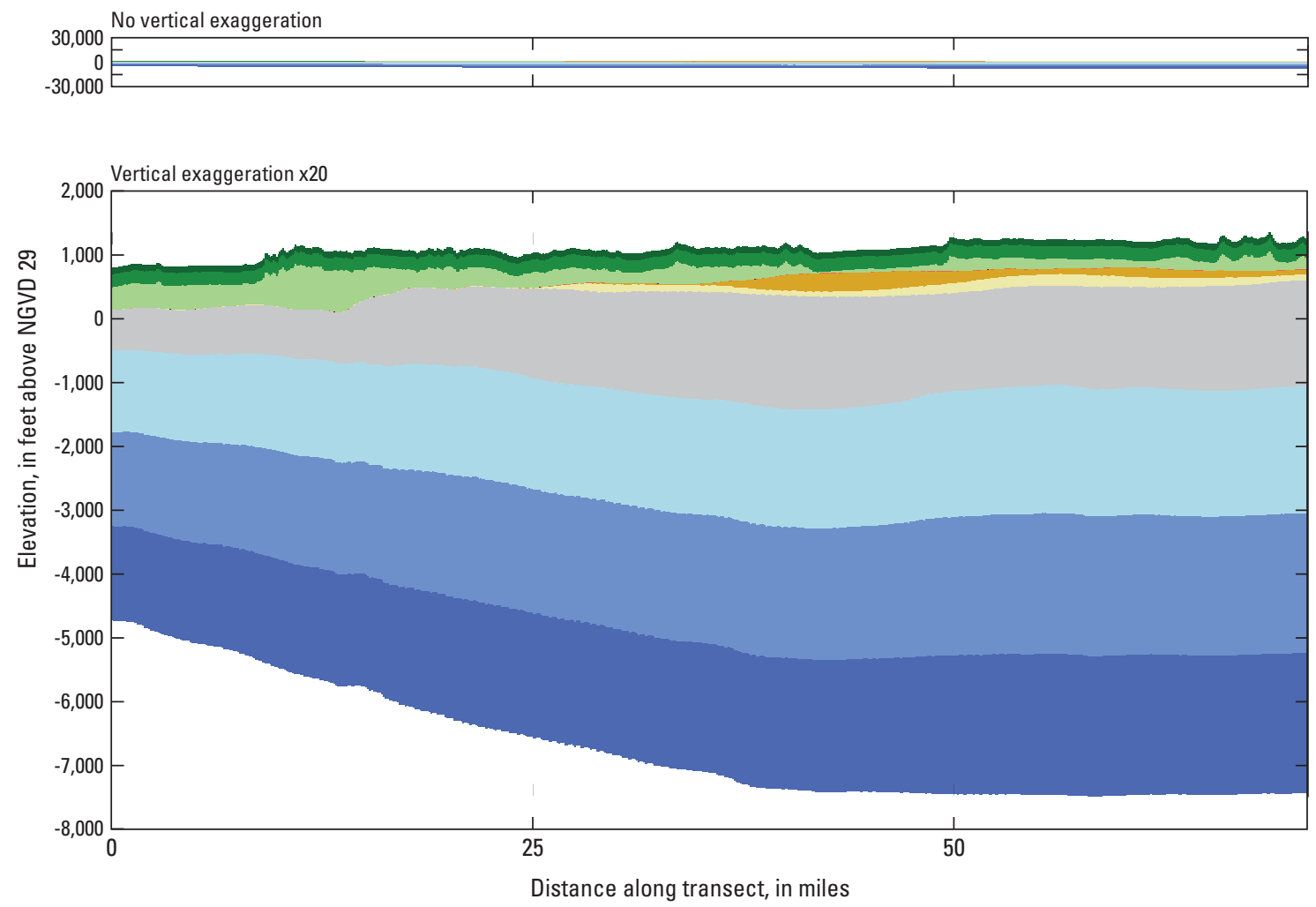

Figure 5. Hydrostratigraphic cross sections for inset models $A$, KALA; $B$, BOARD; $C$, UPFOX; $D$, MANI; and $E$, WHITEDAM. The smaller plot for each inset model shows the cross section without vertical exaggeration; the larger plot shows the cross section

GLAC - upper GLAC - middle GLAC - Iower JURA (pinched out)

\section{EXPLANATION}

PEN1 (pinched out)
PEN2 (pinched out)
MICH
MSHL

DVMS

SLDV - upper SLDV - middle SLDV - lower with indicated vertical exaggeration. Cross section locations correspond to dotted lines in figure 2. 
C. UPFOX, row 575
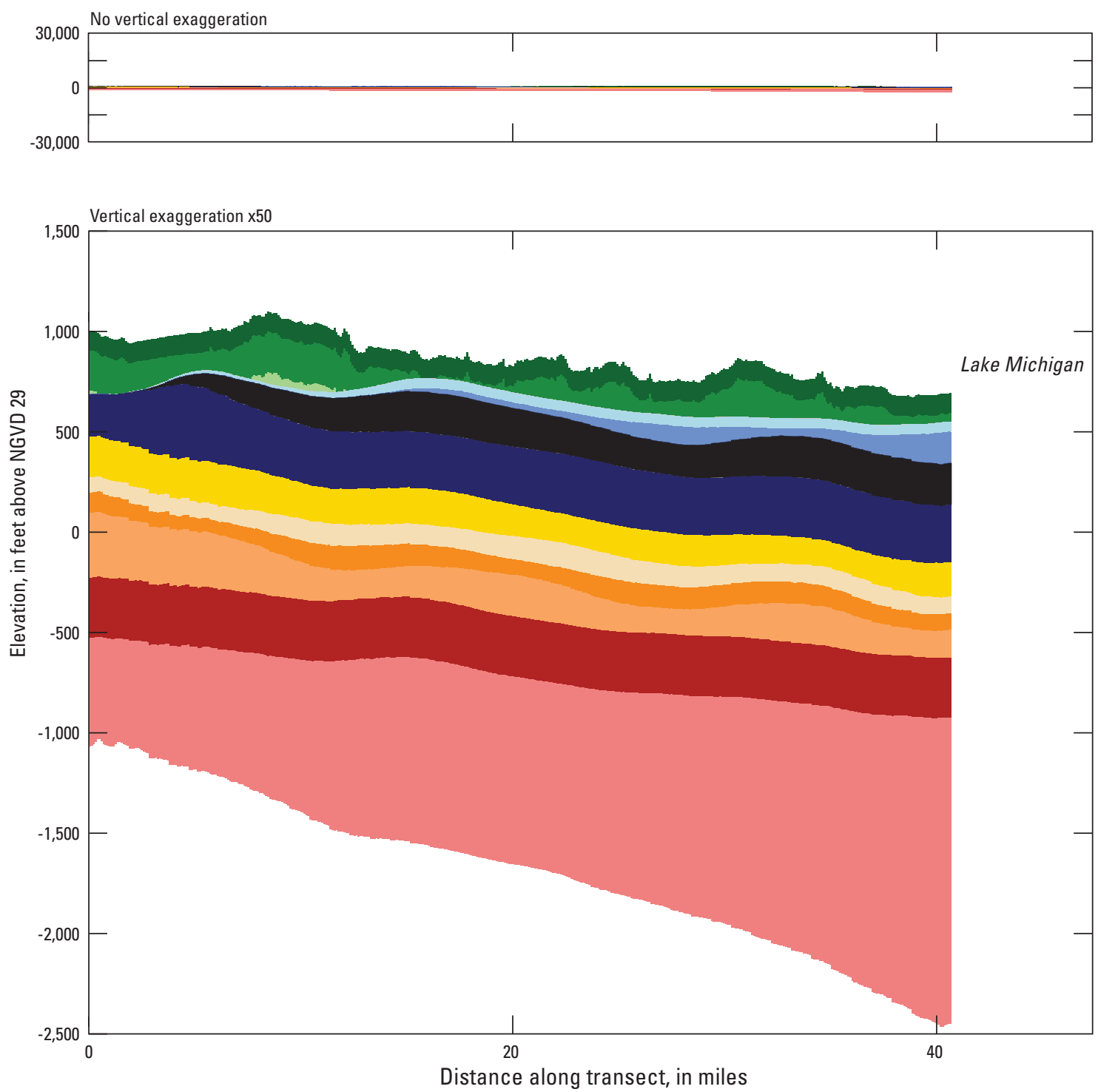

\section{EXPLANATION}

GLAC - upper

GLAC - middle

GLAC - lower

DVMS (pinched out)

SLDV - upper
SLDV - middle

SLDV - lower (pinched out)

MAQU

SNNP

STPT
PCFR

IRGA

EACL

MTSM - upper

MTSM - lower

Figure 5. Hydrostratigraphic cross sections for inset models $A$, KALA; $B, B O A R D ; C$, UPFOX; $D$, MANI; and $E$, WHITEDAM. The smaller plot for each inset model shows the cross section without vertical exaggeration; the larger plot shows the cross section with indicated vertical exaggeration. Cross section locations correspond to dotted lines in figure 2. - Continued 
D. MANI, row 624
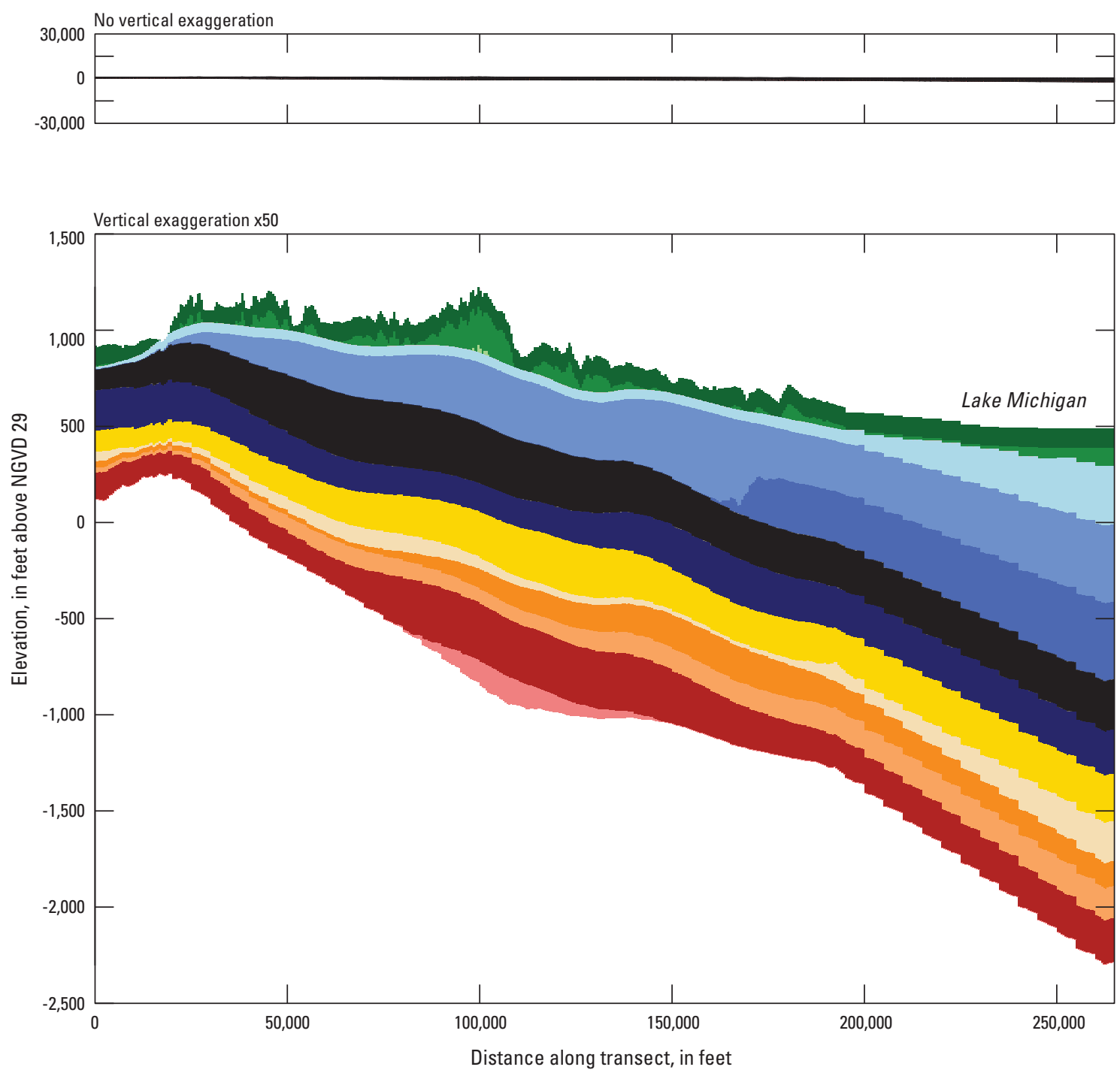

\section{EXPLANATION}

GLAC - upper

GLAC - middle

GLAC - lower

DVMS (pinched out)

SLDV - middle
SLDV - lower
MAQU
SNNP
STPT

PCFR

IRGA

EACL

SLDV - upper

STPT

MTSM - upper

MTSM - lower

Figure 5. Hydrostratigraphic cross sections for inset models $A$, KALA; $B$, BOARD; $C$, UPFOX; $D$, MANI; and $E$, WHITEDAM. The smaller plot for each inset model shows the cross section without vertical exaggeration; the larger plot shows the cross section with indicated vertical exaggeration. Cross section locations correspond to dotted lines in figure 2. - Continued 
E. WHITEDAM, row 300
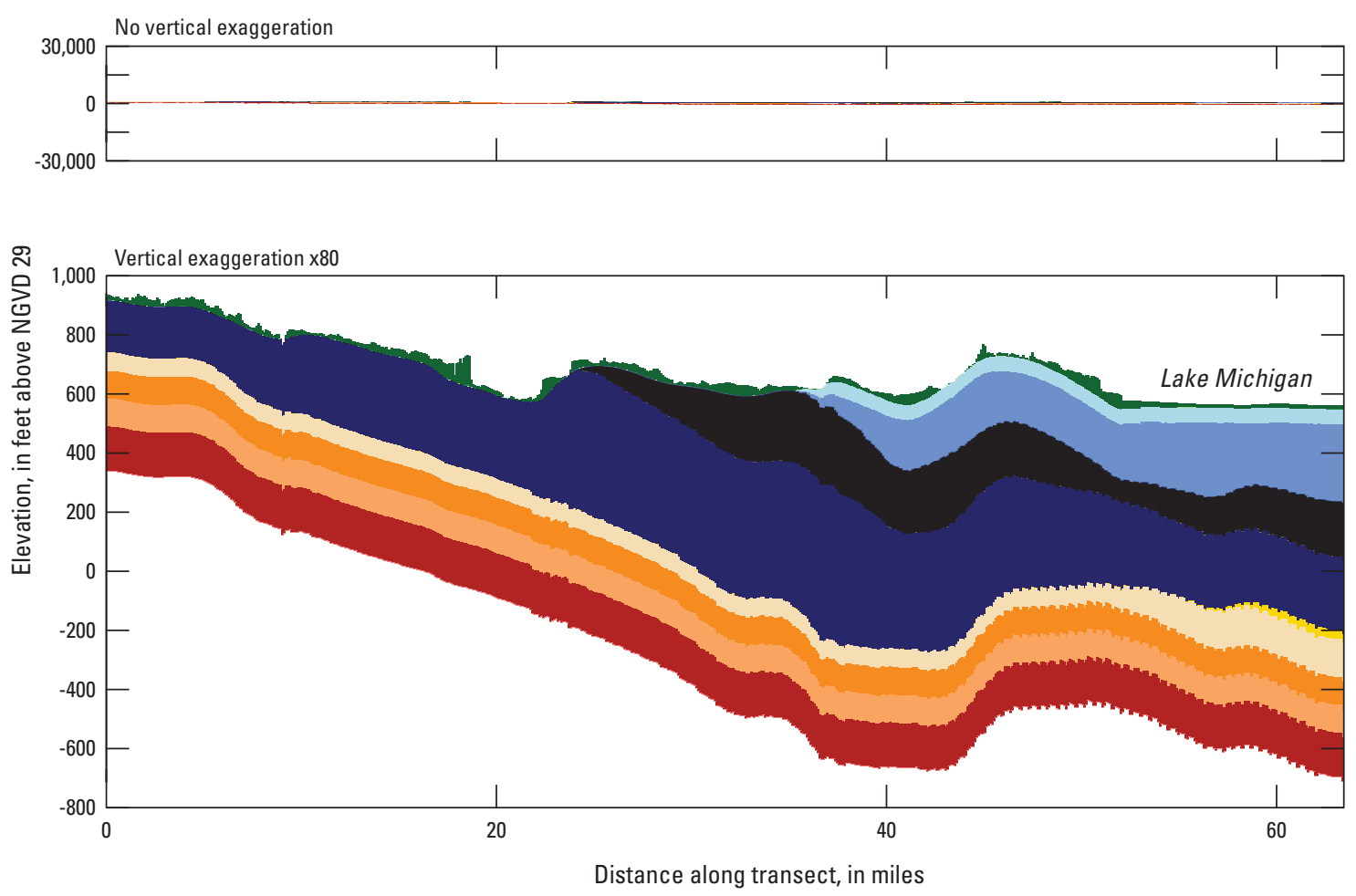

GLAC - upper

GLAC - middle (pinched out)

GLAC - lower (pinched out)

SLDV - upper

SLDV - middle

\section{EXPLANATION}

SLDV - lower (pinched out)

MAOU

SNNP

STPT

PCFR

Figure 5. Hydrostratigraphic cross sections for inset models $A$, KALA; $B, B O A R D ; C$, UPFOX; $D$, MANI; and $E$, WHITEDAM. The smaller plot for each inset model shows the cross section without vertical exaggeration; the larger plot shows the cross section with indicated vertical exaggeration. Cross section locations correspond to dotted lines in figure 2.-Continued 


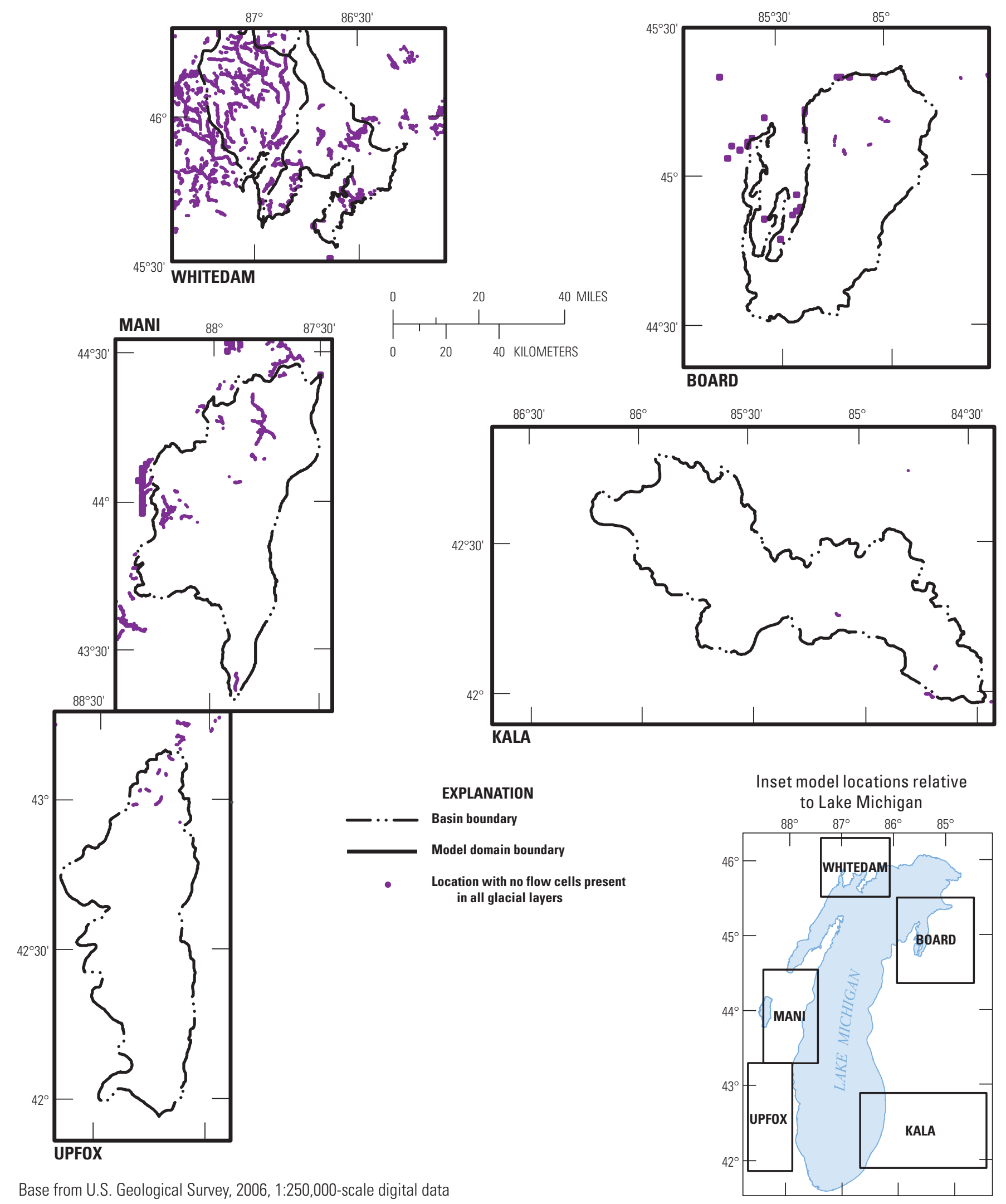

Figure 6. Locations where glacial deposits are absent (all inset models, input). In these areas all three glacial layers were assigned no-flow conditions. 
The geometry and aquifer properties of the bedrock layers in the inset models reproduce conditions in the parent LMB model. The zonation of horizontal and vertical hydraulic conductivity assigned to the bedrock units and layers in the inset models is identical to that in the parent model (Feinstein and others, 2010, section 4.8.3 and appendix 6). The distribution of bedrock layer thicknesses in the LMB model was inherited by the inset models, subject to smoothing along rows and columns to accommodate the refined grid spacing (see section "Reconfiguration of Land Surface and Top Bedrock Surface" for modification of the top bedrock surface elevation). Given the match of horizontal hydraulic conductivity and layer thickness between the LMB and inset models, it follows that the bedrock layer transmissivity is also duplicated everywhere.

\section{Recharge}

The primary source of groundwater in the LMB and derived inset models is recharge. Many studies that combined data collection and some method of estimation linked to the data were used to represent the spatial distribution of recharge in the LMB model (Feinstein and others, 2010, section 4.6).

The studies used topography, climate variables, land use, and soil variables to estimate recharge. The data were incorporated in a recently (2009) developed soil-water-balance (SWB) model used to provide recharge estimates for the LMB model (Westenbroek and others, 2009).

The SWB model generated recharge values through time for the entire LMB model domain, assigning a unique recharge value for each stress period to cells $5,000 \mathrm{ft}$ on a side. The SWB values were subject to a multiplier dictated by the PEST (automated parameter estimation) calibration process (Feinstein and others, 2010; Doherty and Hunt, 2010). The calibrated recharge rates corresponding to the 2001-5 stress period were transferred to the inset model domains. Accordingly, the inset model recharge rates are piece-wise constant over 5,000 -ft by $5,000-\mathrm{ft}$ blocks. Given that the inset model grids consist of uniform $500-\mathrm{ft}$ by $500-\mathrm{ft}$ cells, each recharge block contains 100 inset model cells. The inherited annual recharge distributions for the inset models are shown in figure 7 .

\section{Inset Model Properties Modified from Parent Lake Michigan Basin Model}

Several key inputs to the inset models are not directly inherited from the LMB model, but have been modified in some way. They include the grid spacing, the simulation scheme, the glacial hydraulic conductivity distribution, the elevations (above the North American Vertical Datum of 1929) of the land and bedrock surfaces, and the surface-water network.

\section{Refined Grid Spacing}

The most important difference between the LMB model and the inset models is the refined grid spacing applied to the inset models. As previously mentioned, the 5,000-ft lateral nearfield spacing in the LMB model was refined to a $500-\mathrm{ft}$ lateral spacing in the inset models. The more detailed grid in the inset models allows for more accurate placement of pumped wells (whose stress is automatically assigned to the center of model cells by MODFLOW) than the LMB grid. It also allows for considerably more precise representation of the surface-water network. In addition, the refined grid spacing allows more detailed mapping of the distribution of hydraulic conductivity in the glacial layers and more accurate representation of the land-surface elevation.

Also important is the relation between the density of the surface-water network and the grid. In the upper Midwest the average distance between flowing streams under low-flow conditions is less than 5,000 ft (Feinstein and others, 2016). If all streams had been input to the parent LMB model, almost all water-table cells would have contained a stream as a head-dependent boundary condition, effectively "stapling" the water-table elevation to the prescribed surface-water levels. To avoid predetermining the water-table elevation, many of the lower-order streams, representing about one-half of the combined stream length in the nearfield LMB domain, were omitted. The absence of these sinks introduced some bias into the LMB model results by causing excessive mounding and artificially long pathlines (Feinstein and others, 2016). In the inset models, the grid spacing is fine enough that all first and higher order streams can be included without predetermining the overall water-table elevation. Between 7 and 14 percent of the inland cells of the inset models are occupied by headdependent cells (see table 2; the percentage of inland cells with surface water is equal to the sum of the percentages in the columns for cells representing inland surface-water features inside and outside the HUC8 basins). As a result of the finer grid spacing, the inset model simulated water-level elevations in the shallow part of the flow system are more realistic than those from a coarser grid, partly because all appropriate surface-water sinks are included and partly because gradients that determine groundwater/surface-water interactions are simulated more precisely (Feinstein and others, 2016).

\section{Newton-Raphson Solver and Uniform Density}

The LMB model was run with the U.S. Geological Survey SEAWAT-2000 code for variable-density flow (Langevin and others, 2003, 2007). SEAWAT-2000 combines the features of MODFLOW-2000 (Harbaugh and others, 2000) developed for groundwater flow problems under freshwater conditions and the features of the Mass Transport in Three-Dimensions Multiple Species (MT3DMS) transport code (Zheng and Wang, 1999) developed for simulating the advection, retardation, and decay of dissolved constituents 


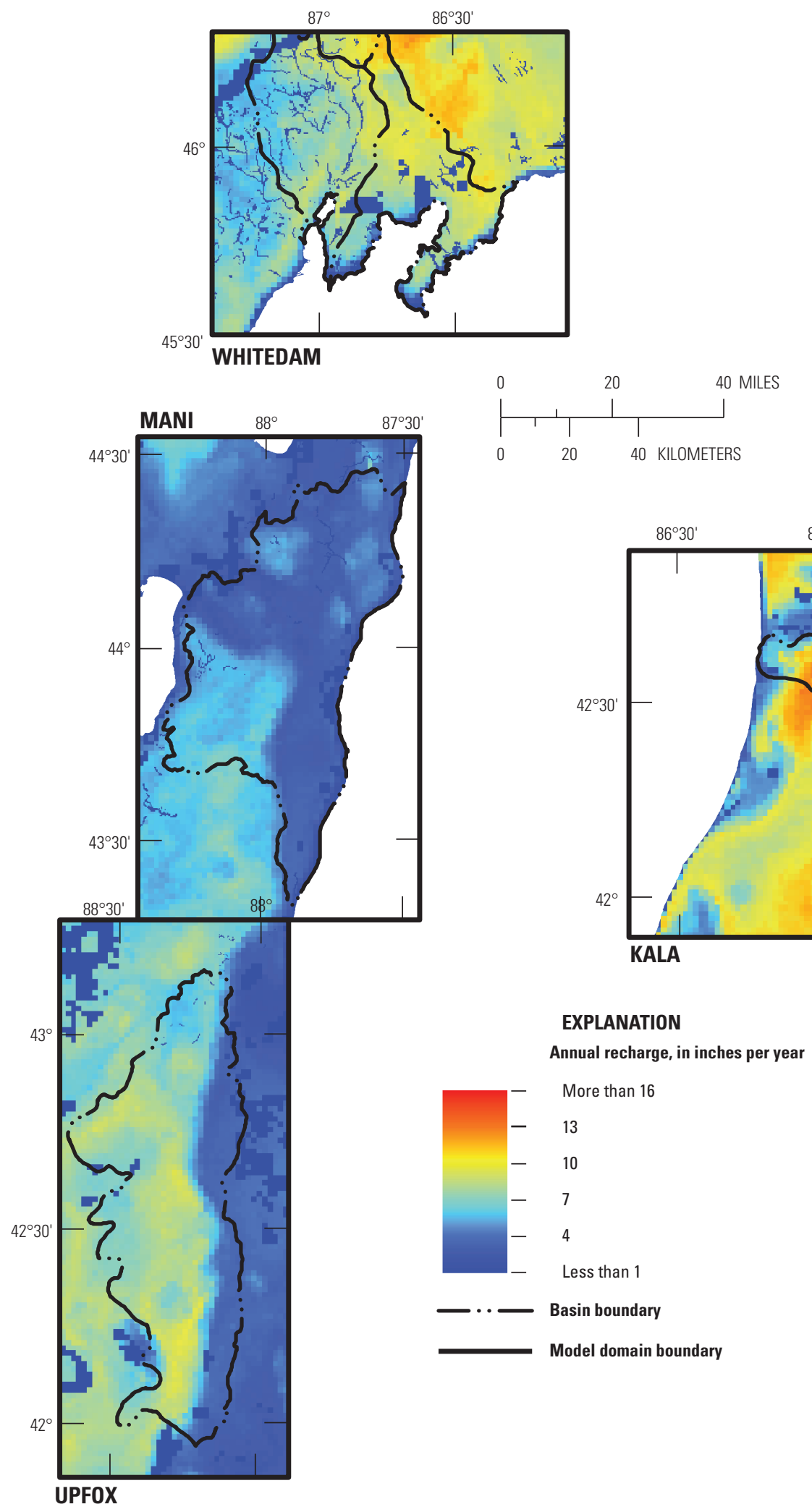

Base from U.S. Geological Survey, 2006, 1:250,000-scale digital data

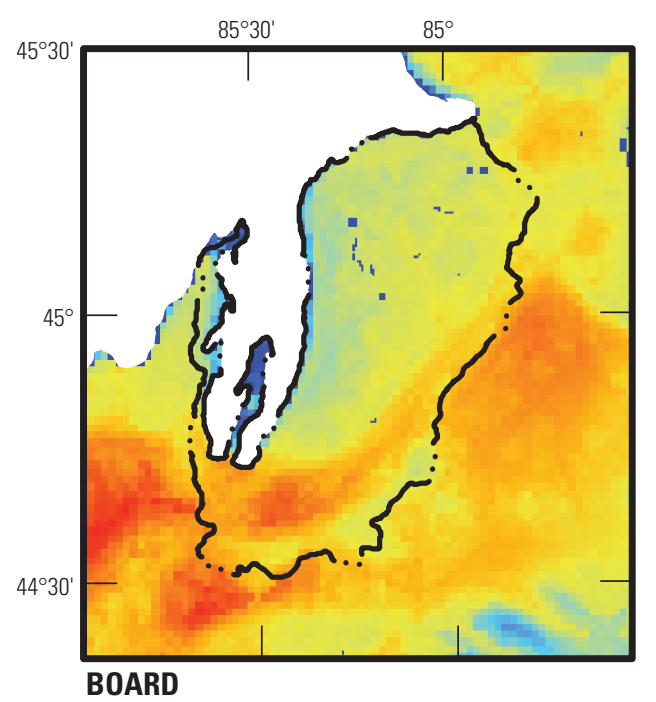

$86^{\circ}-85^{\circ} 30^{\prime}$

$85^{\circ} \quad 84^{\circ} 30^{\prime}$ 
in groundwater. The Preconditioned Conjugate-Gradient 2 method using Picard iterations was applied to the groundwater flow equations (Hill, 1990).

The inset models were run with the MODFLOW-NWT code for uniform density flow (Niswonger and others, 2011). MODFLOW-NWT incorporates a Newton-Raphson code in place of the Picard method that was previously standard to MODFLOW. MODFLOW-NWT overcomes difficulties involving drying and rewetting nonlinearities of the unconfined groundwater flow equation and yields robust values for water-table elevations that may not converge with the Picard method (Feinstein and others, 2012). The focus of the inset models is on the shallow, unconfined part of the groundwater flow system, particularly the interaction of wells with the glacial aquifer system. The MODFLOW-NWT code is well suited for reliably addressing this type of problem.

The focus on the shallow groundwater flow system in the inset models is also a justification for substituting a uniformdensity approach for the variable density approach used in the parent LMB model. Saline conditions in parts of the LMB model domain affect the flow of groundwater, particularly in the deeper parts of the LMB centered in the middle of the Lower Peninsula of Michigan (Feinstein and others, 2010, section 4.10; Lampe, 2009). As mentioned previously, the layers representing the deeper parts of the LMB were omitted from the KALA and BOARD inset models because there was almost no interaction between the deep layers and the upper model layers of interest. West and north of Lake Michigan, saline conditions are more contained than elsewhere in the basin and have little effect on groundwater flow in the deep layers present in the UPFOX, MANI, and WHITEDAM inset models. Consequently, the use of constant head conditions from the unconfined version of the LMB model to establish the edge boundaries of the inset models is assumed to introduce little numerical error at the boundaries, despite the shift from a non-uniform to uniform density formulation. Virtually no error was introduced in the shallow glacial layers where freshwater conditions are predominant and the non-uniform and uniform density solutions converge.

\section{Updating of Glacial Hydraulic Conductivity}

The hydraulic conductivity distribution in the LMB model was computed on the basis of two databases. The first assigns glacial categories, which reflect the depositional history of the shallow deposits across the regional model; the second translates drillers' log records into estimates of the coarse fraction (the proportion of sands and gravels as opposed to the proportion of silts and clays) over the layer intervals. These two sources of information were combined by means of a set of empirical relations to generate estimates of horizontal hydraulic conductivity at cell centers for all three glacial layers (Feinstein and others, 2010, section 4.8).

The Quaternary deposits in the LMB model were divided into the following six categories: clayey till, loamy till, sandy till, fine stratified deposits (often derived from lake sediments), medium/coarse stratified deposits (associated with outwash sediments), and organic deposits). For purposes of hydraulic conductivity mapping, the organic deposits re grouped with loamy till (table 4). The distribution of glacial categories is based on surficial mapping by Fullerton and others (2003) and Soller and Packard (1998). The distribution in some areas also is based on unpublished mapping in support of the LMB model performed in 2006 by the Wisconsin Geological and Natural History Survey and by David Mickelson, emeritus professor of glacial geology at the University of WisconsinMadison. The distribution of glacial categories in the top layer (extending to a maximum depth of $100 \mathrm{ft}$ from land surface) is complex (fig. 8A) and reflects the movements of different lobes of the Laurentide ice sheet. The glacial categories of the layer 2 (from 100 to $300 \mathrm{ft}$ below land surface; fig. $8 \mathrm{~B}$ ) and layer 3 (more than $300 \mathrm{ft}$ below land surface; fig. $8 C$ ) reflect bedrock valleys in Wisconsin and are often filled with fine-grained deposits (Batten and Conlon, 1993). Outside Wisconsin, the types of glacial material at depths below $100 \mathrm{ft}$ have not been mapped at the LMB model regional scale and are considered "undifferentiated" from the overlying glacial material.

The distribution of the coarse fraction in glacial deposits was mapped for the depth intervals associated with each of the top three model layers using hundreds of thousands of well logs assembled in support of the LMB model. The method used to convert the drillers' log descriptions into estimates of coarse fraction for layer intervals is described in Arihood (2009) and Juckem and others (2017). The resulting pattern of the coarse fraction in layer 1 correlates with the map of glacial categories, except in outwash areas where drillers encountered predominantly fine-grained deposits and in areas of clayey till or fine stratified deposits where drillers encountered predominantly coarse-grained deposits. The pattern of the coarse fraction in layer 2 and especially layer 3 is more approximate than in layer 1 , owing to the relative scarcity of boreholes in the deeper glacial layers (Arihood, 2009).

The initial hydraulic-conductivity assignment to the inland Quaternary deposits in the LMB model was a function of both the glacial category and the coarse fraction attributed to inland model cells in layers 1,2 , and 3 . The two variables were combined by means of an empirical "power law" that uses an expected horizontal hydraulic conductivity value and an allowable range that is based on the glacial category, then computes horizontal hydraulic conductivity values within the allowable range that is based on the coarse fraction (Feinstein and others, 2010, appendix 3). The power law yields horizontal hydraulic conductivity values with assumed expected ranking by glacial category: clayey till $<$ fine stratified $<$ loamy till and organic $<$ sandy till $<$ medium and coarse stratified. Where coarse-fraction information is missing, the expected value of horizontal hydraulic conductivity for the mapped glacial categories is assigned directly to all cells. Where the glacial category is unknown (parts of layer 2 and most of layer 3), 
Table 4. $A$, Formulation and $B$, inputs to power law for assigning horizontal hydraulic conductivity to glacial deposits in layers 1,2 , and 3 of the inset models.

$\left[\mathrm{K}_{\mathrm{h}}\right.$, horizontal hydraulic conductivity; LMB, Lake Michigan Basin; \%, percent; $\mathrm{ft} / \mathrm{day}$, foot per day; $\mathrm{K}_{v}$, vertical hydraulic conductivity. Values correspond to calibrated input to unconfined LMB model. $\mathrm{K}_{\mathrm{h}} / \mathrm{K}_{\mathrm{v}}$ is the vertical anisotropy ratio between horizontal and vertical hydraulic conductivity]

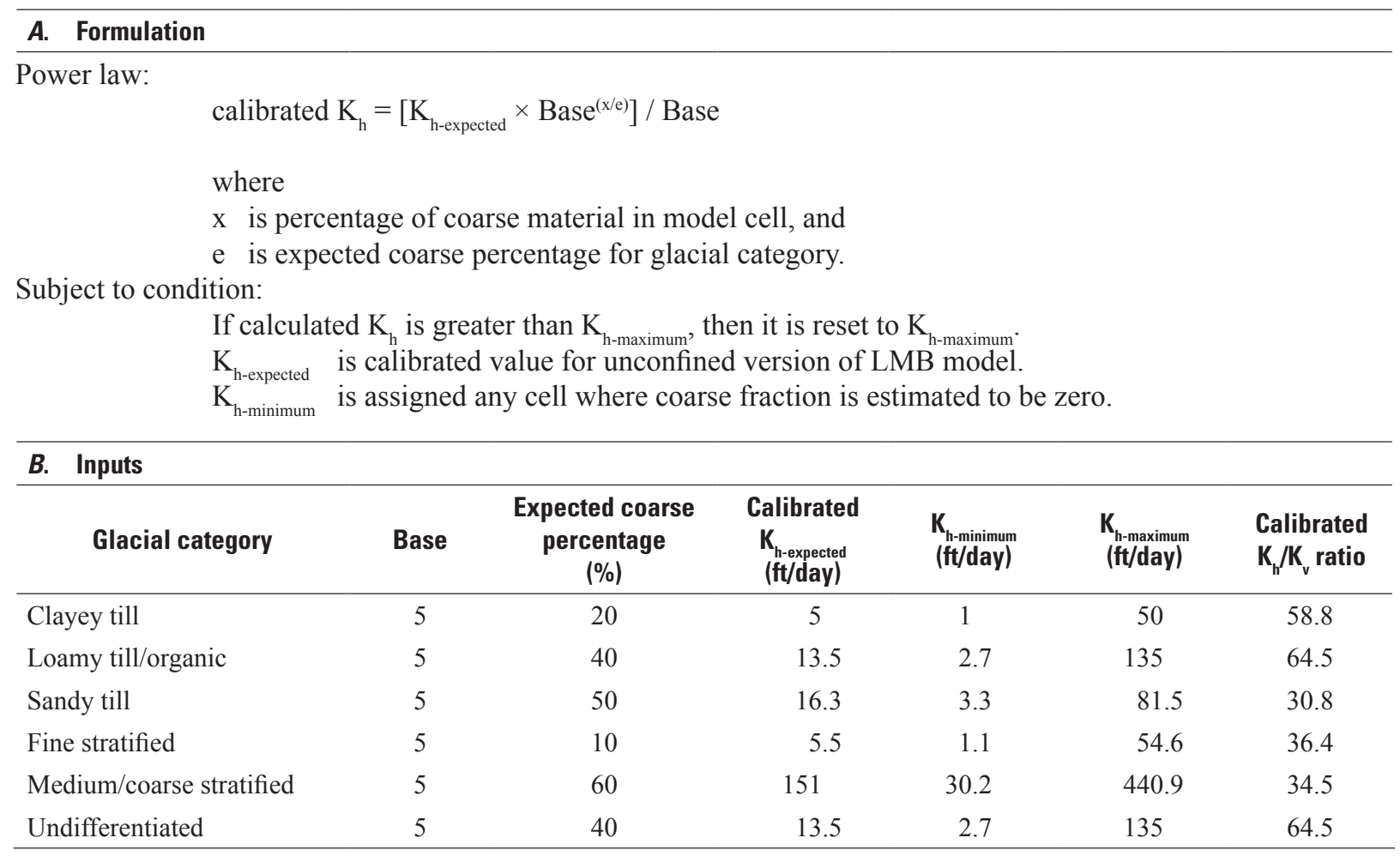

"undifferentiated" parameters corresponding to loamy till are assumed.

The expected value of the horizontal hydraulic conductivity for each glacial category was updated as part of the calibration process of the LMB model. The form of the empirical power law and its calibrated inputs for the unconfined version of the LMB model are presented in table 4. These exact same relations were applied to the inset models. Plots of the power-law relations between the coarse fraction and the assigned horizontal hydraulic conductivity for each glacial category (figs. $9 A-C$ ) show the possible range of horizontal hydraulic values. For example, the value that corresponds to the expected coarse fraction for clayey till is $5 \mathrm{ft} / \mathrm{d}$, but the allowable range is from 1 to $50 \mathrm{ft} / \mathrm{d}$.

The calibrated value for vertical hydraulic conductivity for any given inland glacial cell was derived from the computed horizontal hydraulic conductivity by means of a single vertical anisotropy factor, which is the ratio of horizontal to vertical hydraulic conductivity. That factor was initially set to 20:1 everywhere, then updated during the calibration of the LMB model. The calibrated ratios for distinct glacial categories, ranging from about 30:1 to 64:1, are listed in table 4 . Accordingly, a horizontal hydraulic conductivity value of $3 \mathrm{ft} / \mathrm{d}$ in a cell associated with clayey till, given the calibrated vertical anisotropy value of 58.8 for that glacial category, automatically yields a vertical hydraulic conductivity value of $0.051 \mathrm{ft} / \mathrm{d}$ for the cell.

The same computational process used to generate horizontal and vertical hydraulic conductivity for the unconfined version of the LMB model has been applied to each of the inset models. In addition, the original mapping of glacial categories (figs. $8 A-C$ ) is maintained. However, the database of water-well drillers' logs assembled for the LMB model (Arihood, 2009) has been updated to a more recent standardized database of records published by the U.S. Geological Survey (Bayless and others, 2017). The location of the wells with drillers' logs, by layer, is shown in figures $10 A-C$; clearly there are more logs available for shallow depths in the glacial deposits than for other depths. The coarse fractions at the log locations, formerly interpolated to the $5,000-\mathrm{ft}$ spacing of the LMB model, were interpolated to the finer $500-\mathrm{ft}$ grid spacing. The interpolation was performed using ordinary kriging with a linear semi-variogram. The kriging parameters are presented for each inset model in table $5 \mathrm{~A}$. The resulting interpolated coarse fraction distribution for layer 1 across the inset model domains is shown in figure 11. The power-law formulation (table 4) is then applied to generate the horizontal and vertical hydraulic conductivity distribution across inland cells of the inset model domains. 
A. Layer 1

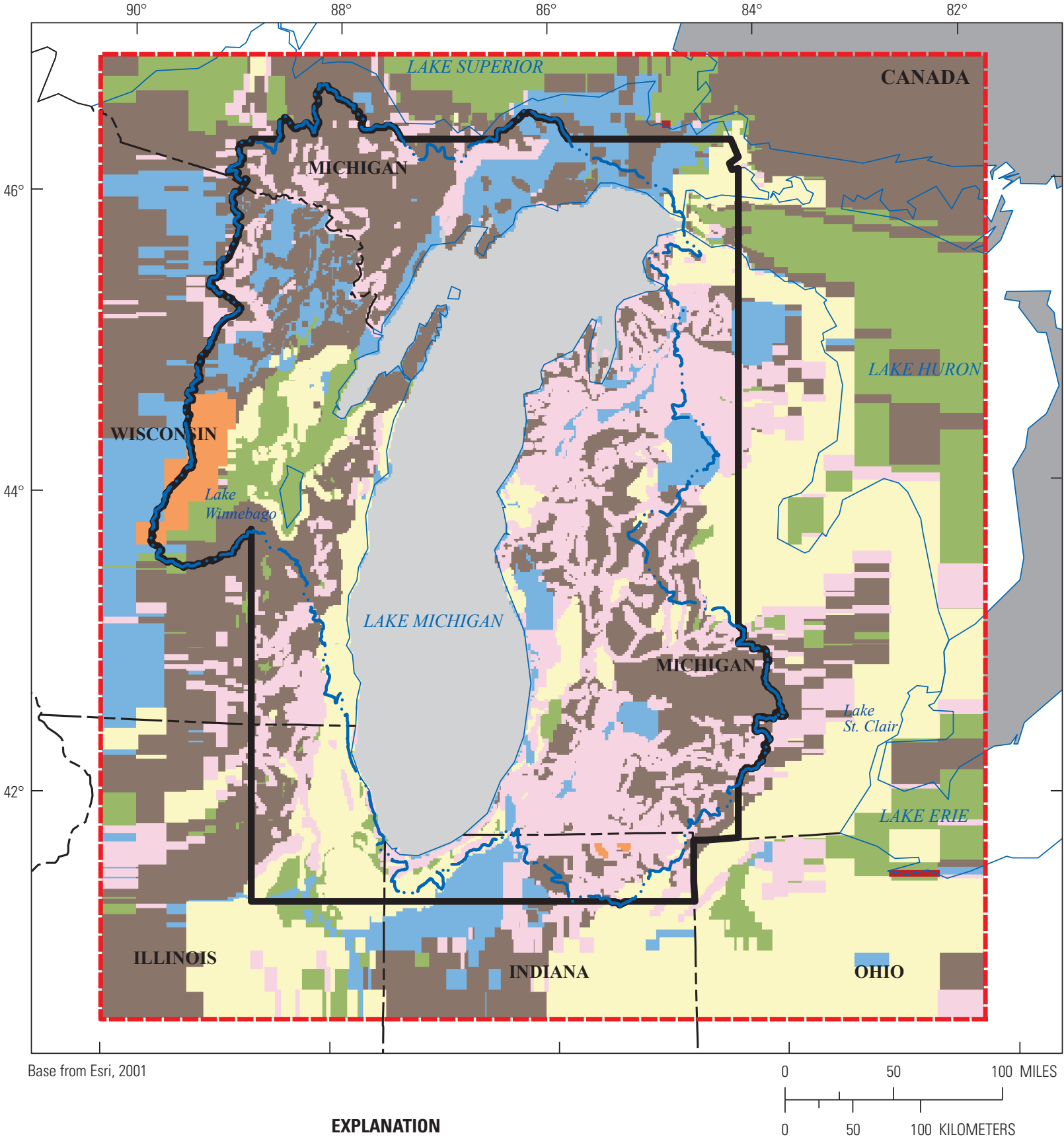

Glacial categories in layer 1 (Fullerton and others, 2003; Soller and Packard, 1998)

\begin{tabular}{|l|l|}
\hline Clayey till & Fine stratified \\
\hline Loamy till & Medium stratified \\
\hline Sandy till & Coarse stratified \\
\hline Organic & Quaternary absent \\
\hline
\end{tabular}

Model domain boundary

- -. - Lake Michigan Basin boundary

Model nearfield boundary

Figure 8. Glacial categories in the Lake Michigan Basin model domain. $A$, layer $1 ; B$, layer 2 ; and $C$, layer 3 . 


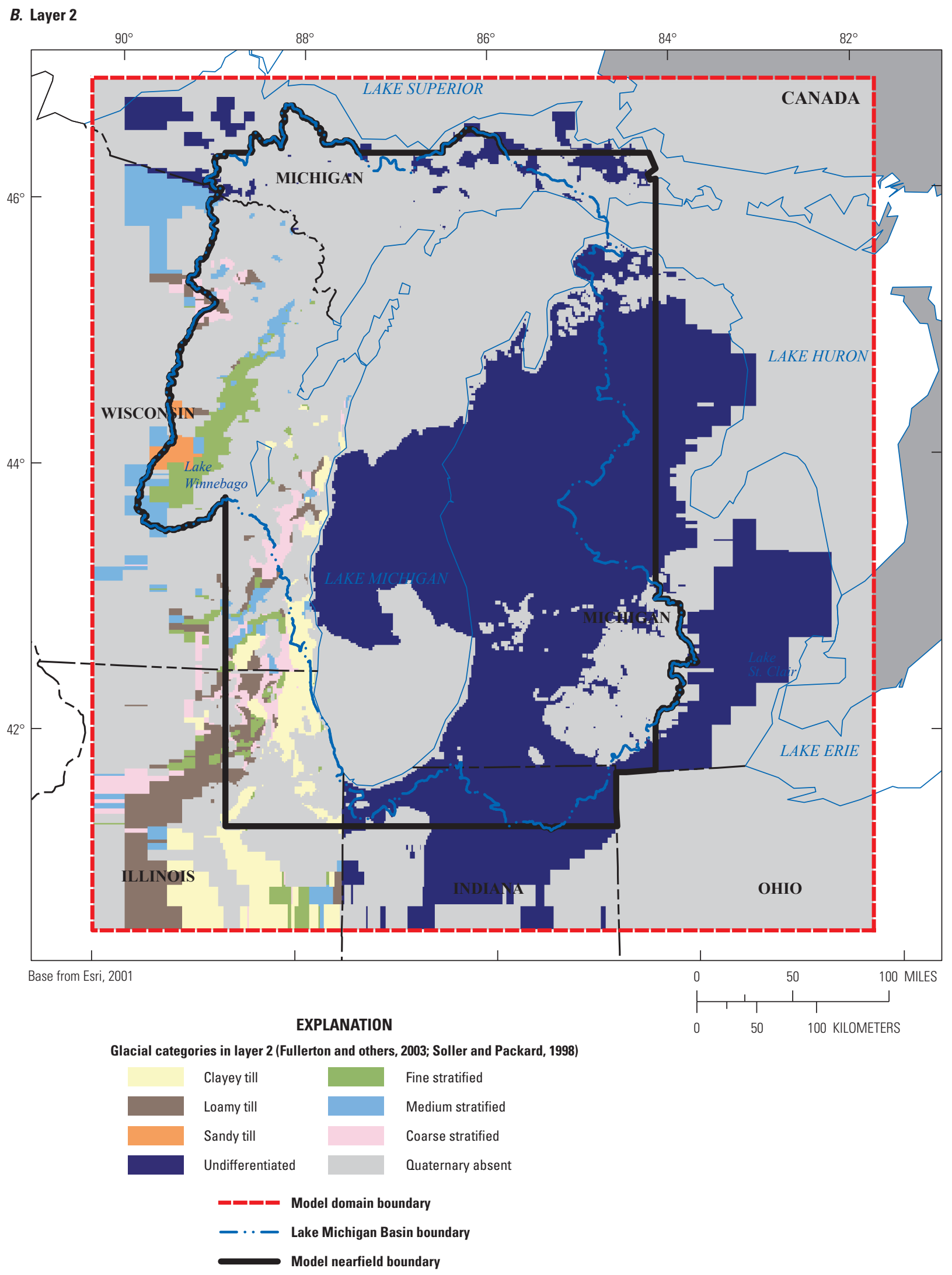

Figure 8. Glacial categories in the Lake Michigan Basin model domain. $A$, layer $1 ; B$, layer 2; and $C$, layer 3.-Continued 
C. Layer 3

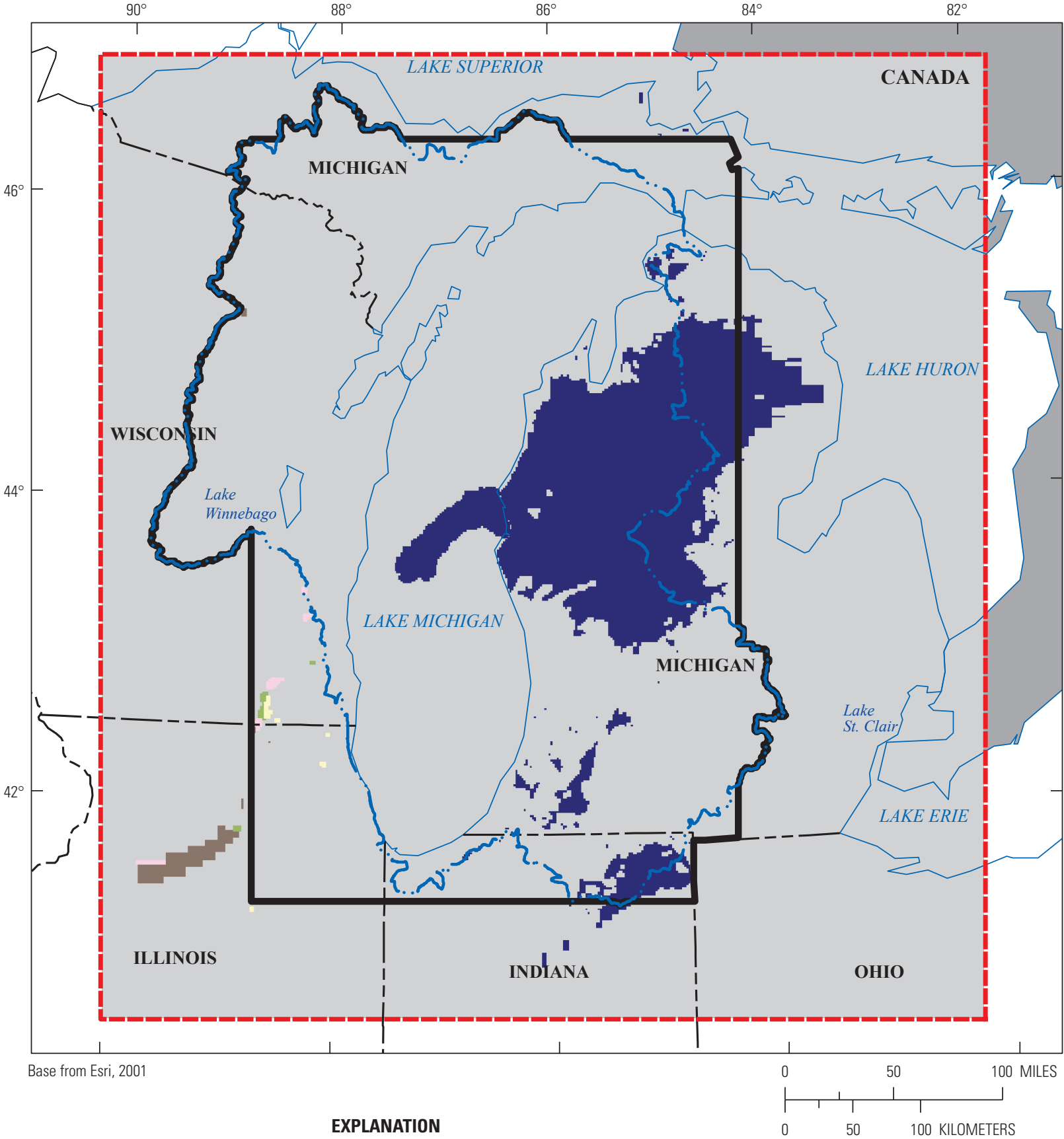

Glacial categories in layer 3 (Fullerton and others, 2003; Soller and Packard, 1998)

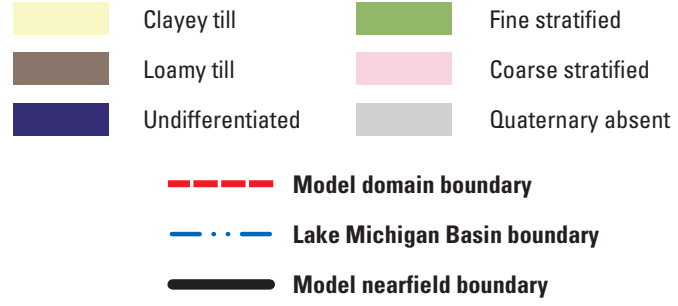

Figure 8. Glacial categories in the Lake Michigan Basin model domain. $A$, layer $1 ; B$, layer 2; and $C$, layer 3.-Continued 
A. Clayey till and fine stratified deposits

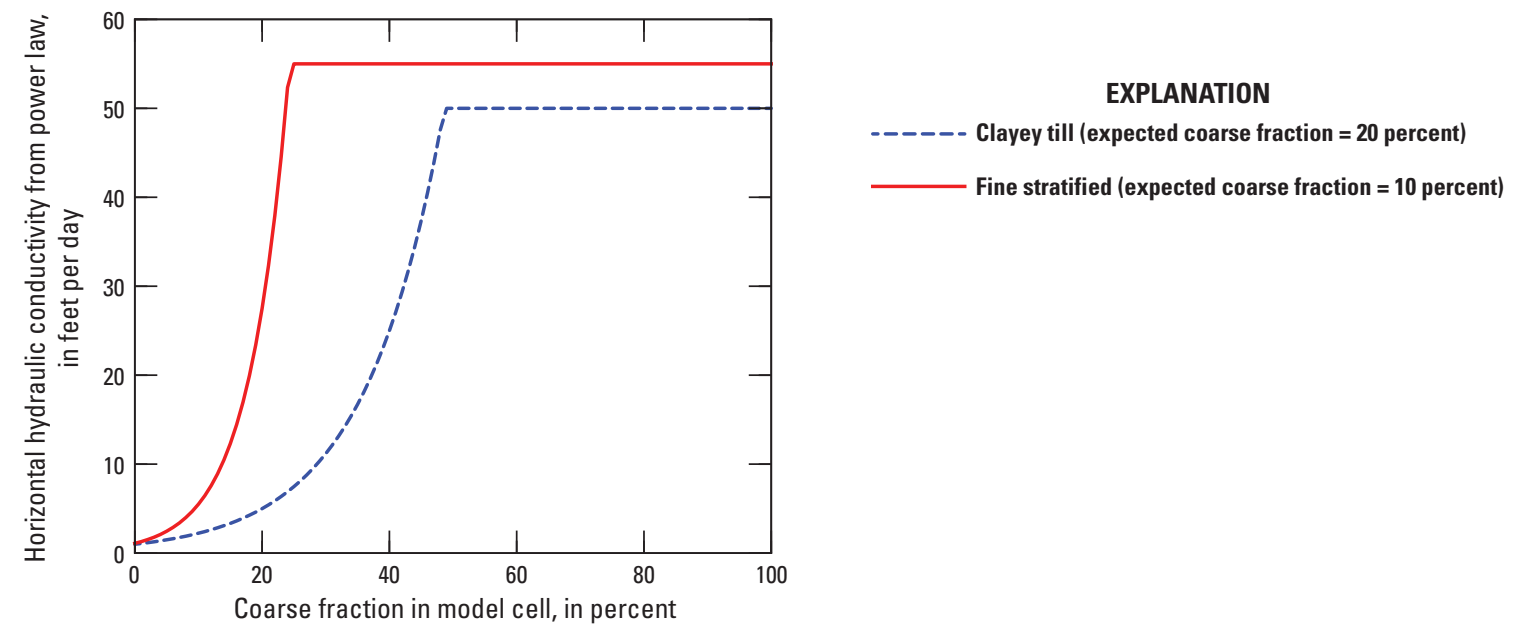

B. Loamy till/organic and sandy till deposits

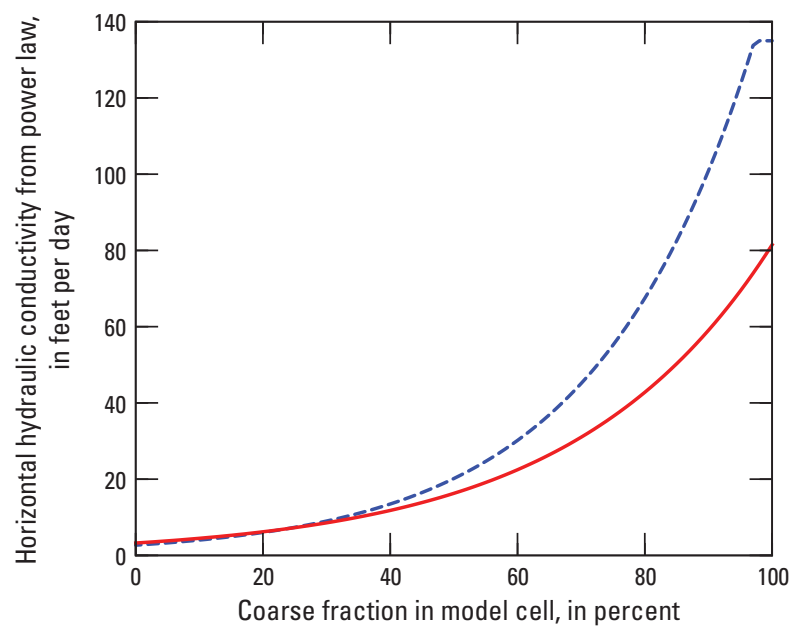

EXPLANATION

- - - - - Loamy till/organic (expected coarse fraction $=40$ percent)

Sandy till (expected coarse fraction $=50$ percent)

C. Medium/coarse stratified and undifferentiated deposits

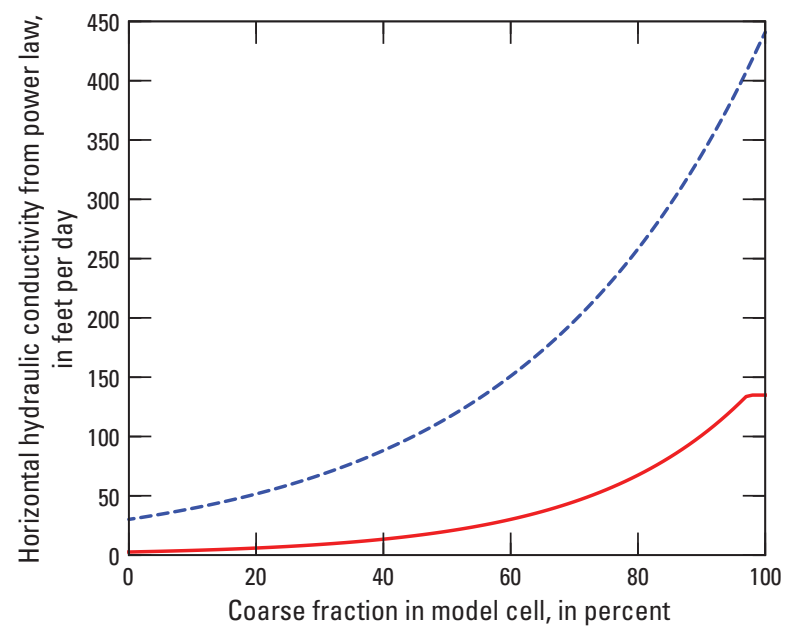

EXPLANATION

- - - - - Medium/coarse stratified (expected coarse fraction $=60$ percent)

- Undifferentiated (expected coarse fraction $=40$ percent)

Figure 9. Power-law curves for assigning horizontal hydraulic conductivity to glacial categories based on the spatial distribution of the coarse fraction in layers 1, 2, and 3 of the inset models. $A$, clayey till and fine stratified deposits; $B$, loamy till/ organic and sandy till deposits; and $C$, medium/coarse stratified and undifferentiated deposits. 
A. Layer 1
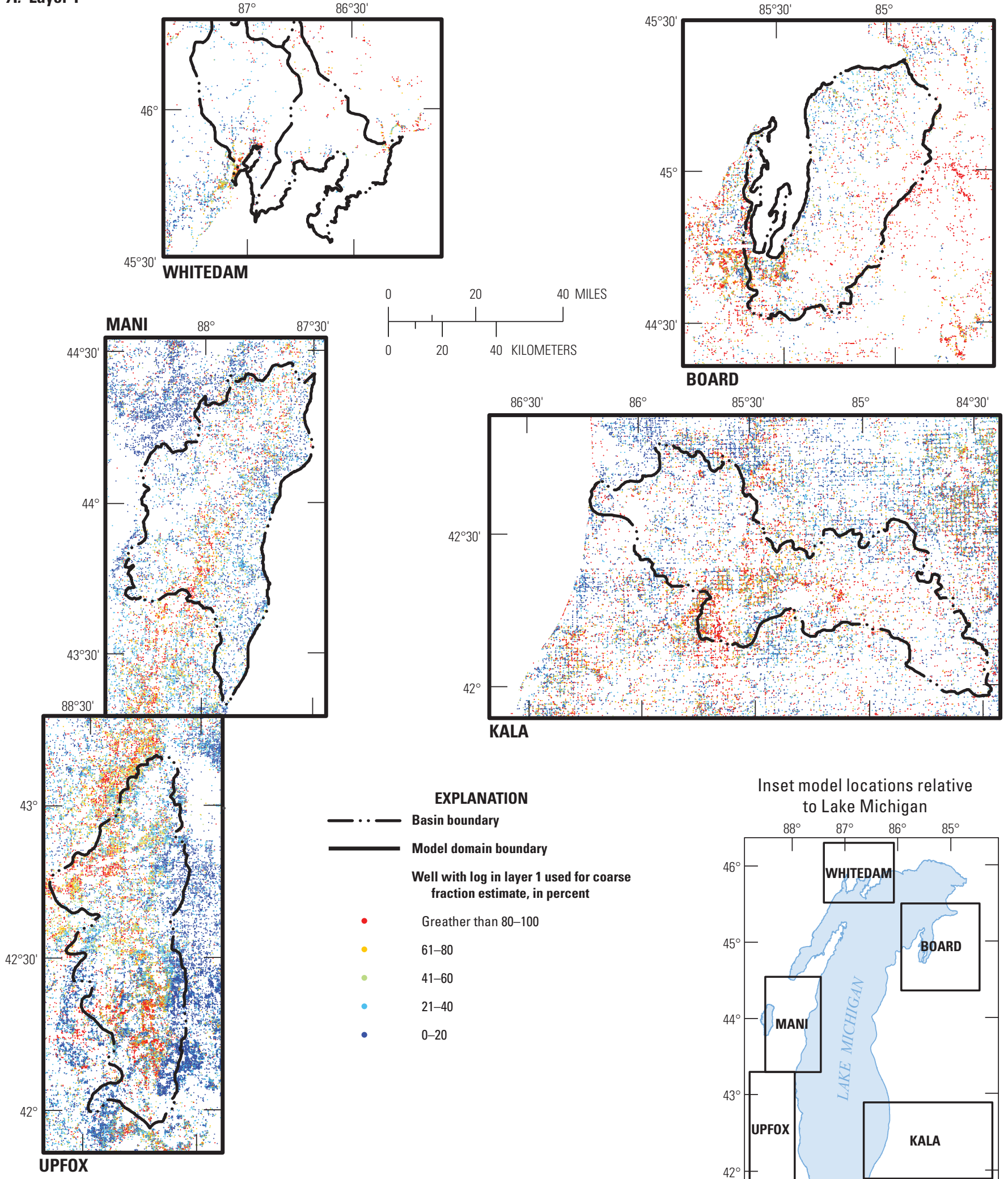
B. Layer 2
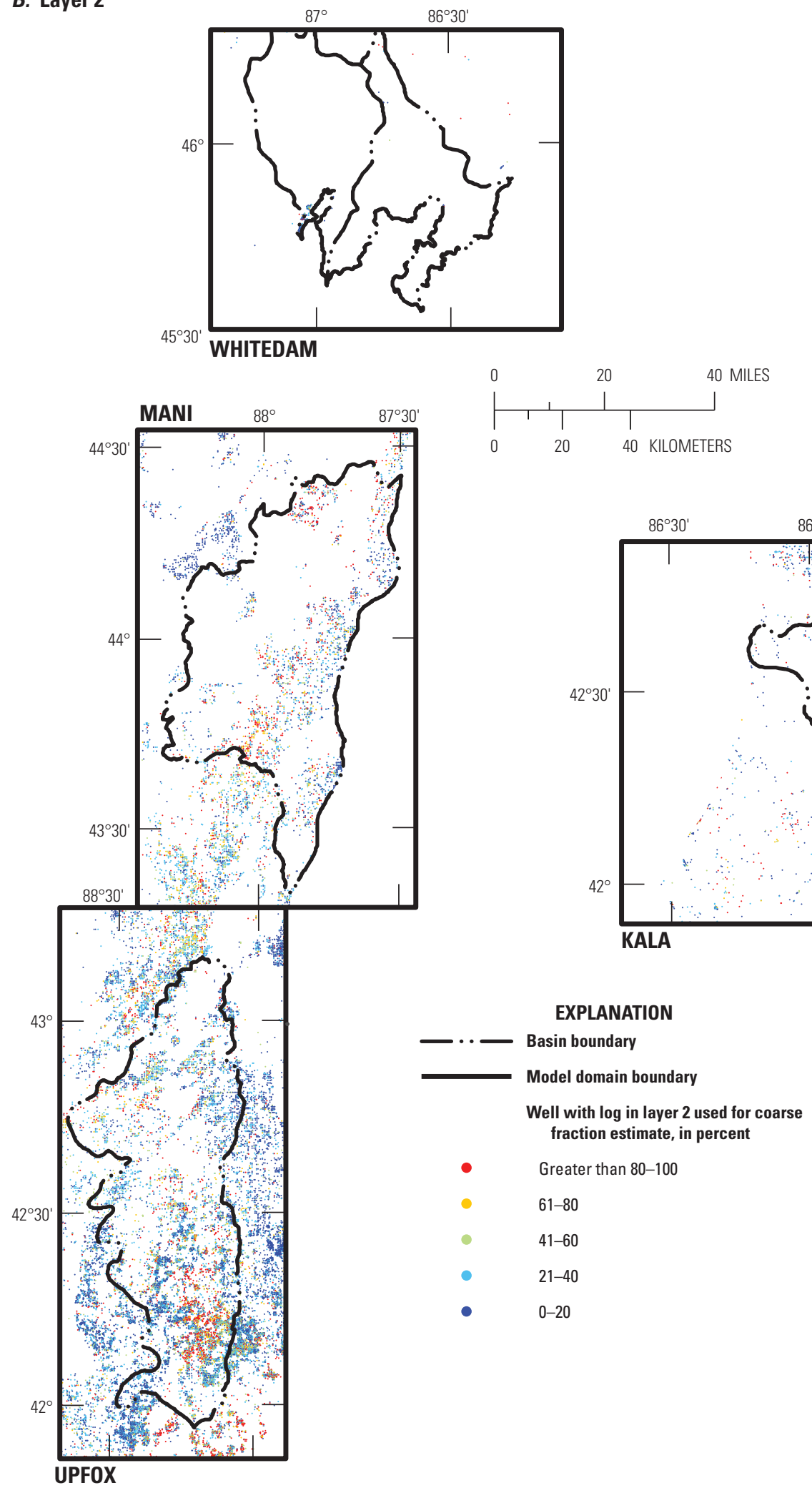

Base from U.S. Geological Survey, 2006, 1:250,000-scale digital data

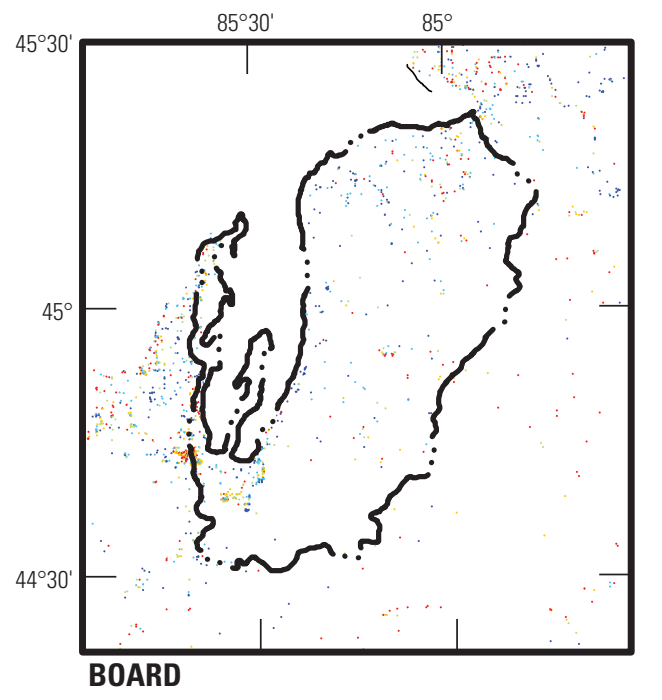


C. Layer 3
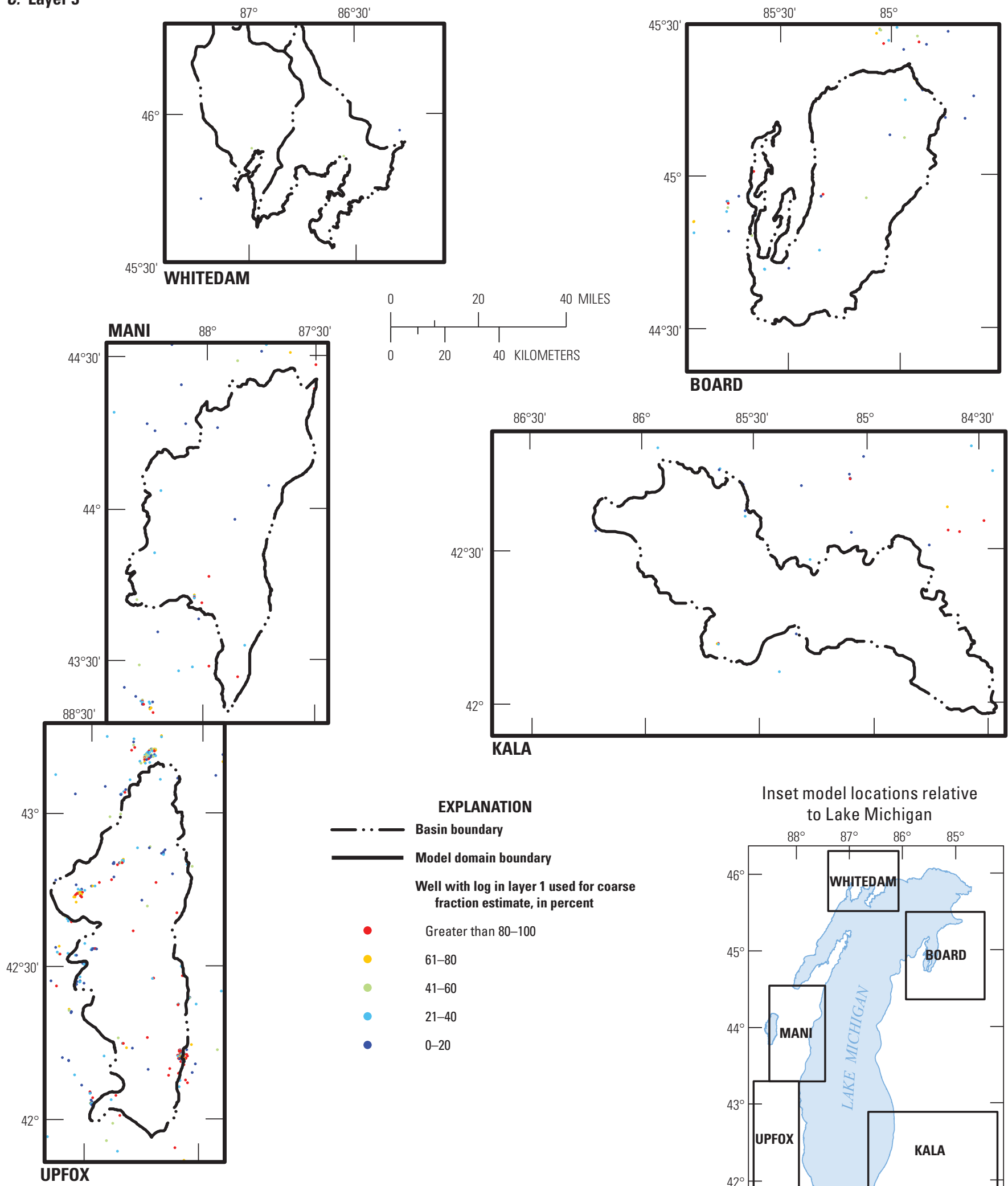

Base from U.S. Geological Survey, 2006, 1:250,000-scale digital data

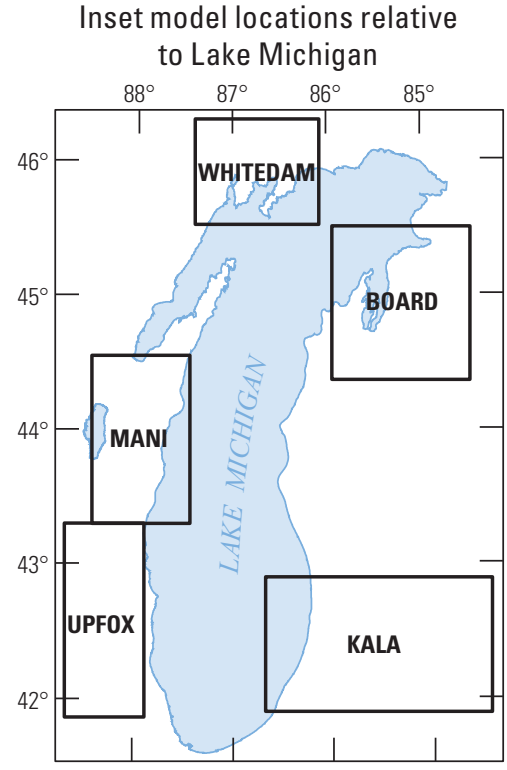

Figure 10. Coarse fraction for glacial deposits at log locations (all inset models). $A$, layer 1 ; $B$, layer 2; and $C$, layer $3 .-$ Continued 
Table 5. Kriging parameters for $A$, interpolation of coarse fraction of glacial deposits for inset models using linear semivariogram and ordinary kriging and $B$, interpolation of bedrock surface for inset models using linear semi-variogram and simple kriging.

[The linear kriging model relates lag distance [h], range [a], partial sill [c], and nugget [c0] to the semivariance [ $\mathrm{\gamma}(\mathrm{h})]$ according to the following formula: $\mathrm{y}(\mathrm{h})=\mathrm{c} 0+\mathrm{c} *(\mathrm{~h} / \mathrm{a})$ for $\mathrm{h}<\mathrm{a} ; \mathrm{y}(\mathrm{h})=\mathrm{c} 0+\mathrm{c}$ for $\mathrm{h} \geq \mathrm{a}$. ---, dimensionless; $\mathrm{ft}$, foot]

\section{A. Kriging parameters for interpolation of coarse fraction of glacial deposits for inset models using linear semi-variogram and ordinary kriging}

[Coarse fraction interpolated in model layers 1,2, and 3]

\begin{tabular}{|c|c|c|c|c|c|c|}
\hline Inset model & Layer & $\begin{array}{c}\text { Number model } \\
\text { cells with logs } \\
(---)\end{array}$ & $\begin{array}{c}\text { Lag size } \\
\text { increment } \\
\text { (ft) }\end{array}$ & $\begin{array}{c}\text { Range } \\
\text { (ft) }\end{array}$ & $\begin{array}{c}\text { Partial sill* } \\
\text { (semi-variance) }\end{array}$ & $\begin{array}{c}\text { Nugget } \\
\text { (semi-variance) }\end{array}$ \\
\hline KALA & 1 & 30,360 & 1,499 & 686,515 & 41 & 1,242 \\
\hline KALA & 2 & 3,708 & 1,499 & 1,499 & 46 & 1,123 \\
\hline KALA & 3 & 31 & 1,499 & 1,499 & 0 & 1,477 \\
\hline BOARD & 1 & 9,652 & 1,499 & 523,132 & 294 & 1,042 \\
\hline BOARD & 2 & 1,634 & 1,499 & 533,624 & 350 & 937 \\
\hline BOARD & 3 & 45 & 1,499 & 1,499 & 44 & 866 \\
\hline UPFOX & 1 & 37,157 & 1,499 & 563,603 & 140 & 986 \\
\hline UPFOX & 2 & 20,937 & 1,499 & 1,499 & 155 & 680 \\
\hline UPFOX & 3 & 342 & 1,499 & 1,499 & 0 & 1,220 \\
\hline MANI & 1 & 13,204 & 1,499 & 255,441 & 204 & 936 \\
\hline MANI & 2 & 4,488 & 1,499 & 96,720 & 335 & 812 \\
\hline MANI & 3 & 50 & 1,499 & 188,867 & 490 & 1,036 \\
\hline WHITEDAM & 1 & 2,449 & 1,499 & 370,239 & 656 & 931 \\
\hline WHITEDAM & 2 & 194 & 1,499 & 295,292 & 1,580 & 396 \\
\hline WHITEDAM & 3 & 4 & 1,499 & 73,448 & 1,302 & 0 \\
\hline
\end{tabular}

*Partial sill is the difference between the sill and the nugget.

\section{B. Kriging parameters for interpolation of bedrock surface for inset models using linear semi-variogram and simple kriging}

[The bedrock surface corresponds to the elevation of the bottom of layer $3=$ top of layer 4 for all inset models]

\begin{tabular}{lccccc}
\hline \multicolumn{1}{c}{ Inset model } & $\begin{array}{c}\text { Number model } \\
\text { cells with logs } \\
(---)\end{array}$ & $\begin{array}{c}\text { Lag size } \\
\text { increment } \\
\text { (ft) }\end{array}$ & $\begin{array}{c}\text { Range } \\
\text { (ft) }\end{array}$ & $\begin{array}{c}\text { Partial sill* } \\
\text { (semi-variance) }\end{array}$ & $\begin{array}{c}\text { Nugget } \\
\text { (semi-variance) }\end{array}$ \\
\hline KALA & 3,558 & 57,545 & 362,307 & 281 & 191 \\
BOARD & 1,289 & 39,110 & 338,111 & 750 & 2,781 \\
UPFOX & 24,784 & 47,222 & 288,313 & 636 & 1,358 \\
MANI & 14,734 & 43,738 & 524,859 & 419 & 2,260 \\
WHITEDAM & 3,083 & 36,567 & 181,617 & 172 & 439 \\
\hline
\end{tabular}

\footnotetext{
*Partial sill is the difference between the sill and the nugget.
} 


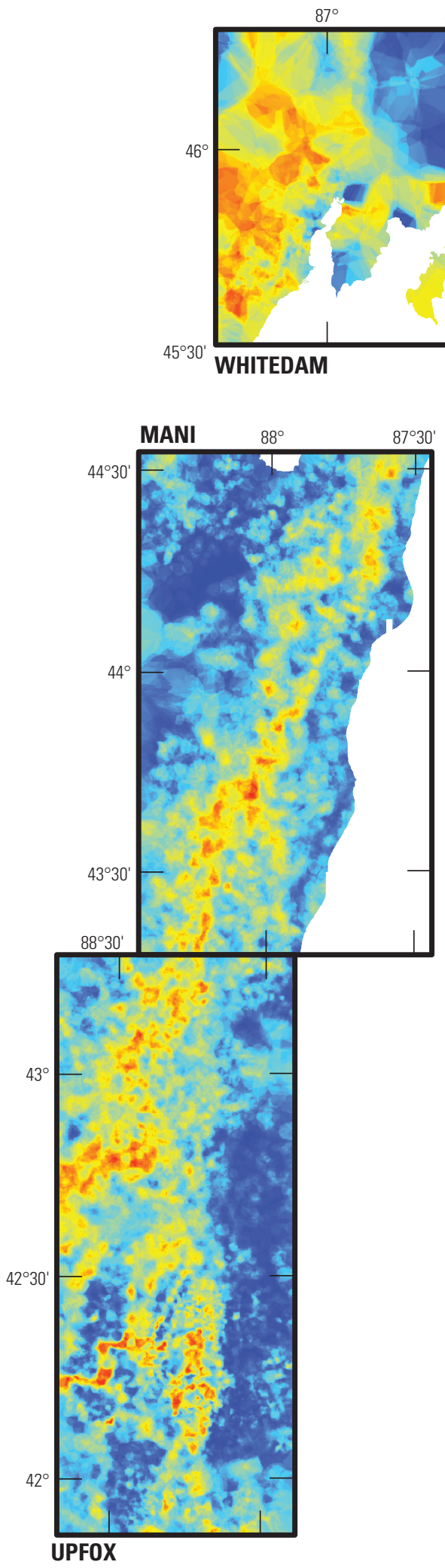

$86^{\circ} 30^{\prime}$
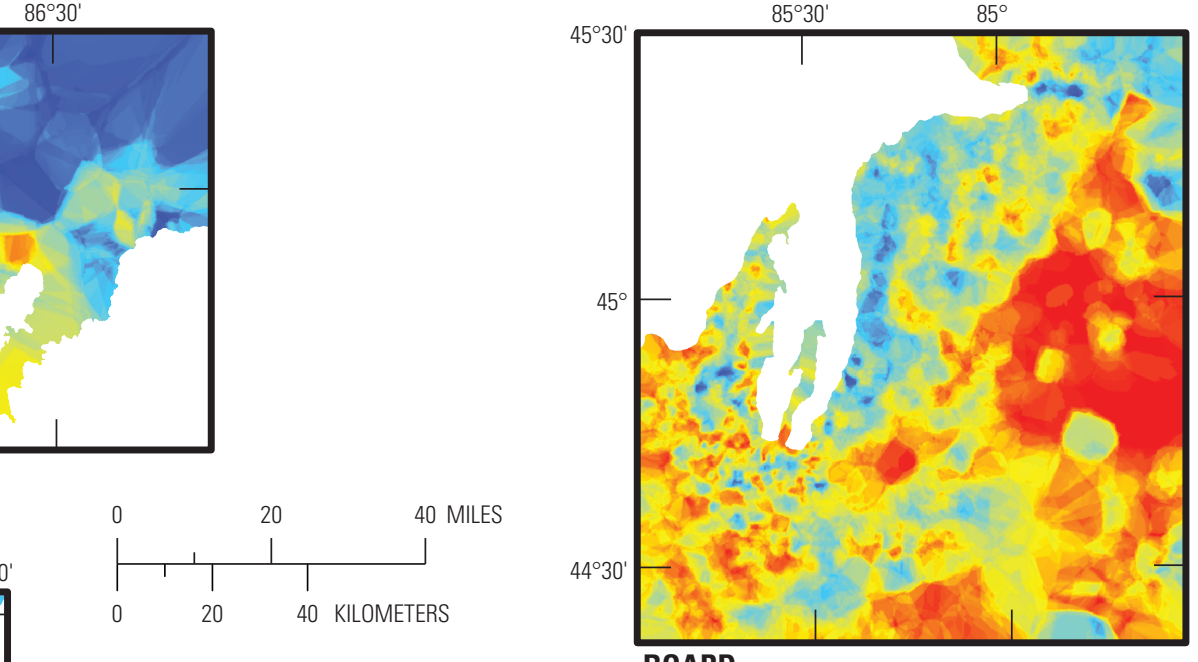

BOARD

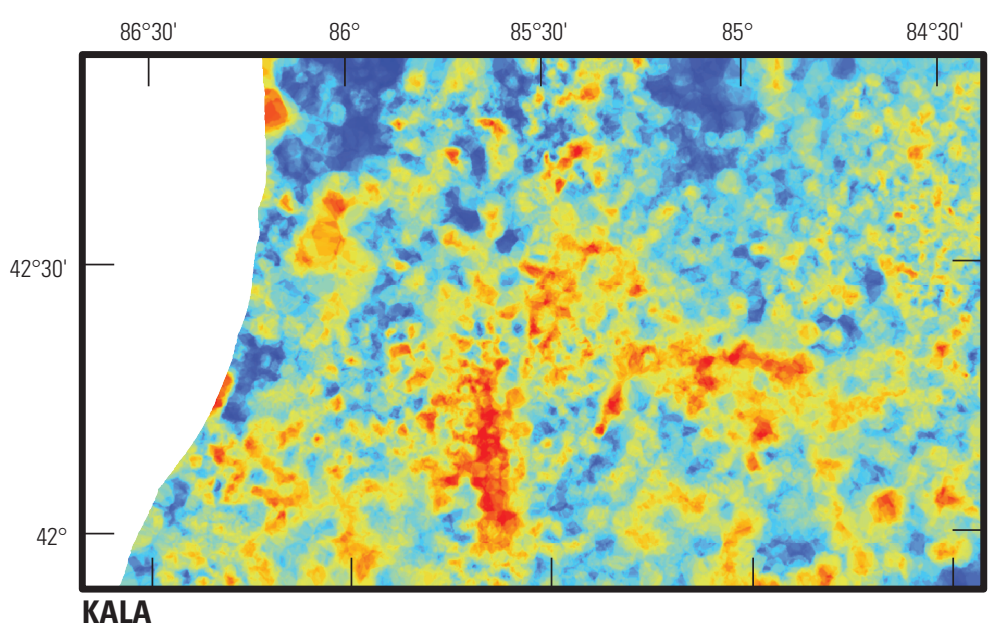

\section{EXPLANATION}

Layer 1 interpolated coarse fraction, in percent

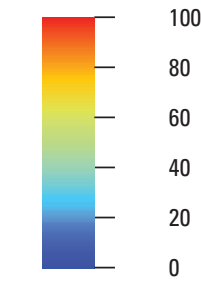

Model domain boundary

Base from U.S. Geological Survey, 2006, 1:250,000-scale digital data

Inset model locations relative to Lake Michigan

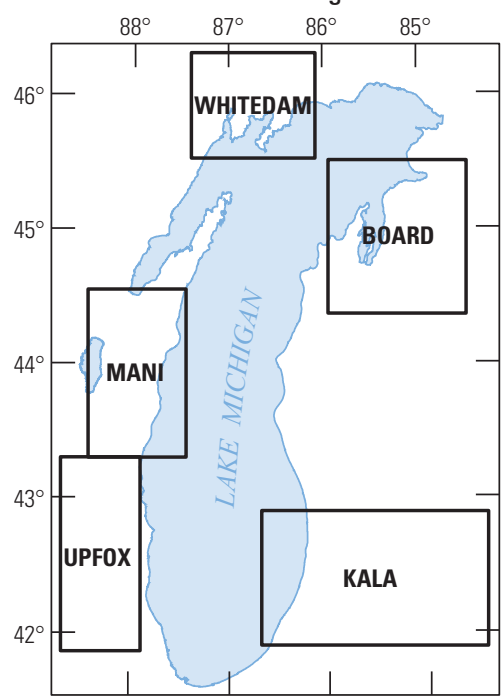

Figure 11. Interpolated coarse fraction of glacial deposits in layer 1 (all inset models). 
The contrast for horizontal hydraulic conductivity distribution from the parent LMB model to the inset model for the KALA domain for model layer 1 is shown in figures $12 A-B$. Figure $12 A$ shows the original (inherited) distribution from the LMB model; figure $12 B$ shows the updated distribution, which is based on the revised coarse fraction data. A degree of blockiness evident in both plots; blockiness is an effect of the underlying methodology, which produces the smoothly varying coarse fraction distribution as overlying the more discrete pattern of glacial categories displayed in figure $8 \mathrm{~A}$.

The updated horizontal hydraulic conductivity for all the inset models is shown in figure 13. It presents the "composite" glacial value, that is, the averages across all three glacial layers with the value in each layer weighted by its saturated thickness. The variability within inset model domains and between inset model domains is evident. The patterns are influenced in part by the distribution of glacial categories and in part by the trends in coarse fraction. It is noteworthy that the composite horizontal hydraulic conductivity for the BOARD model is not greater than those for the other models despite the abundance of the coarse fraction in the top layer (fig. 10A). The reason for the discrepancy is that the simulated water table in the BOARD model is often at the bottom of layer 1 or in layer 2. The thick glacial deposits in layers 2 and 3 of the model (fig. $5 B$ ) fall into the "undifferentiated" glacial category (figs. $8 B-C$ ) and, therefore, were assigned a moderate horizontal hydraulic conductivity.

The hydraulic conductivity values of the bedrock units in the inset models (layer 4 and below) were not updated; they are identical to the values input to the parent LMB model. As a result, the values for each bedrock layer are piece-wise uniform over 5,000-ft by 5,000-ft blocks corresponding to the LMB model grid spacing. Descriptions, tables, and maps of the hydraulic conductivity values spanning the inset model domains for the various bedrock units are given in Feinstein and others (2010; see section 4.8.3 and appendixes 4 and 6).

\section{Reconfiguration of Land Surface and Top Bedrock Surface}

The land-surface elevations for each of the inset models correspond to the top of layer 1 . This surface does not play a direct role in the MODFLOW calculations, but it is useful for computing model results, such as the depth to the water table. It is also important to implement the layering algorithm for dividing up the glacial thickness because that algorithm depends on depth from land surface.

The inset model land-surface elevation values at the $500-\mathrm{ft}$ grid spacing were derived from the National Elevation Dataset (U.S. Geological Survey, 2014). The average elevation at 10-meter grid spacing was computed for the area of each inland row/column location and assigned to the top of layer 1 . Given the relief within a model cell, the average value can often be $20 \mathrm{ft}$ above or below the minimum and maximum land-surface elevation in a layer 1 cell.
The depth from the top of layer 1 to the bedrock surface defines the total glacial thickness for the inset models. For all the inset models, this surface corresponds to the bottom elevation of layer 3, equivalent to the top elevation of layer 4 . The inset models start with the top bedrock surface mapped for the parent LMB model at the 5,000-ft grid spacing (Feinstein and others, 2010, section 4.2). However, this inherited surface is subject to two modifications. First, the same standardized dataset of well drillers' logs used to map the coarse fraction of the glacial material (Bayless and others, 2017) was employed to refine the inherited surface according to an algorithm presented in Juckem and others (2017). In brief, this method is used to compare the depth from land surface to the inherited top bedrock surface with the bedrock depth recorded in the pertinent logs in the standardized database. The top bedrock surface was adjusted at the log location and in the vicinity of the log location according to the Simple Kriging method (Kitanidis, 1997) that incorporates a nugget (to dampen the effect of the log at the node) and a set of weights that decrease with distance. Simple Kriging, as opposed to Ordinary or Universal Kriging, was used to ensure that where data from logs are sparse or lacking, the bedrock surface from the LMB model was left unchanged. The parameters for each inset model are presented in table $5 B$.

The adjustment of the bedrock surface was conducted at the 5,000-ft grid spacing. The top and bottom elevations of the underlying bedrock layers in each inset model were then further adjusted to preserve their inherited thickness from the parent model, again at the 5,000-ft grid spacing. A final modification was needed to overcome the blockiness when the adjusted bedrock surface was transferred to the inset models refined lateral grid spacing. A Gaussian filter (Jones and others, 2001-16) was applied to smooth the bottom of layer 3 in the row and column directions to conform to the $500-\mathrm{ft}$ grid spacing.

The three-step modification of the top bedrock surface is illustrated for the KALA inset model in figures $14 A-C$. The updated surfaces corresponding to the top of layer 4 (equivalent to the bottom of layer 3 ) for all the inset models are shown in figure 15. For the top and bottom surfaces of the underlying bedrock layer below the top of layer 4 , smoothness was enforced by kriging the elevations at the 5,000-ft grid spacing with a linear semi-variogram to fill in the intermediate elevations at the $500-\mathrm{ft}$ grid spacing. The smoothing of the top and bottom bedrock surfaces also smooths the cell thickness of the bedrock layers to accommodate the 500 -ft grid spacing.

As discussed previously, the algorithm for determining the top and bottom elevations of the three glacial layers depends on the land surface and the top bedrock surface. The updating of these surfaces generated relatively minor adjustments to the glacial layering inherited from the parent LMB model while smoothing the elevation of the glacial layers to prevent abrupt transitions between cells. One consistent effect of the more detailed bedrock surface in the inset models is that low areas in the bedrock are better captured in the inset models than in the parent LMB model. As a result, the maximum 
A. KALA, layer 1, based on inherited Lake Michigan Basin model distribution (5,000-foot grid spacing)

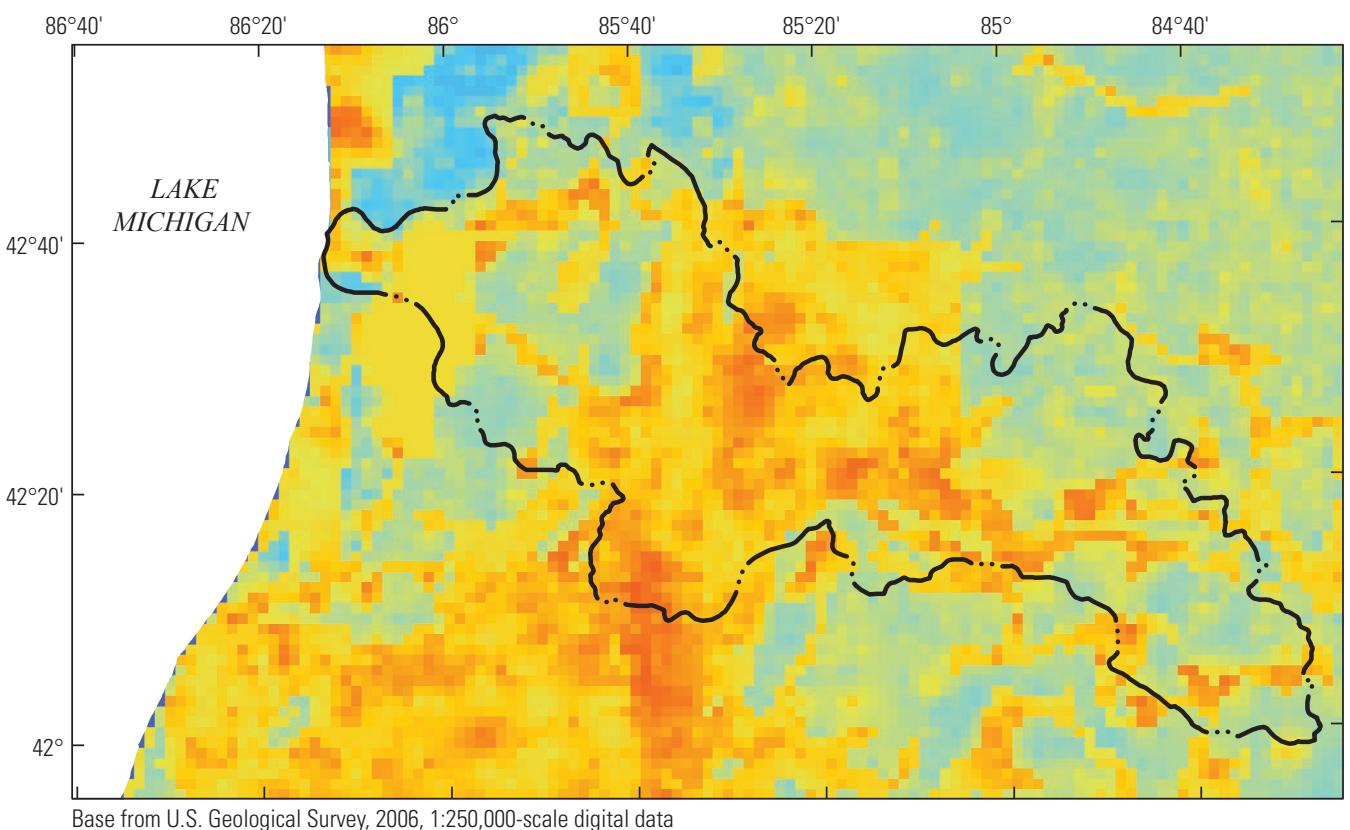

B. KALA, layer 1, based on coarse fraction distribution and glacial categories (500-foot grid spacing)

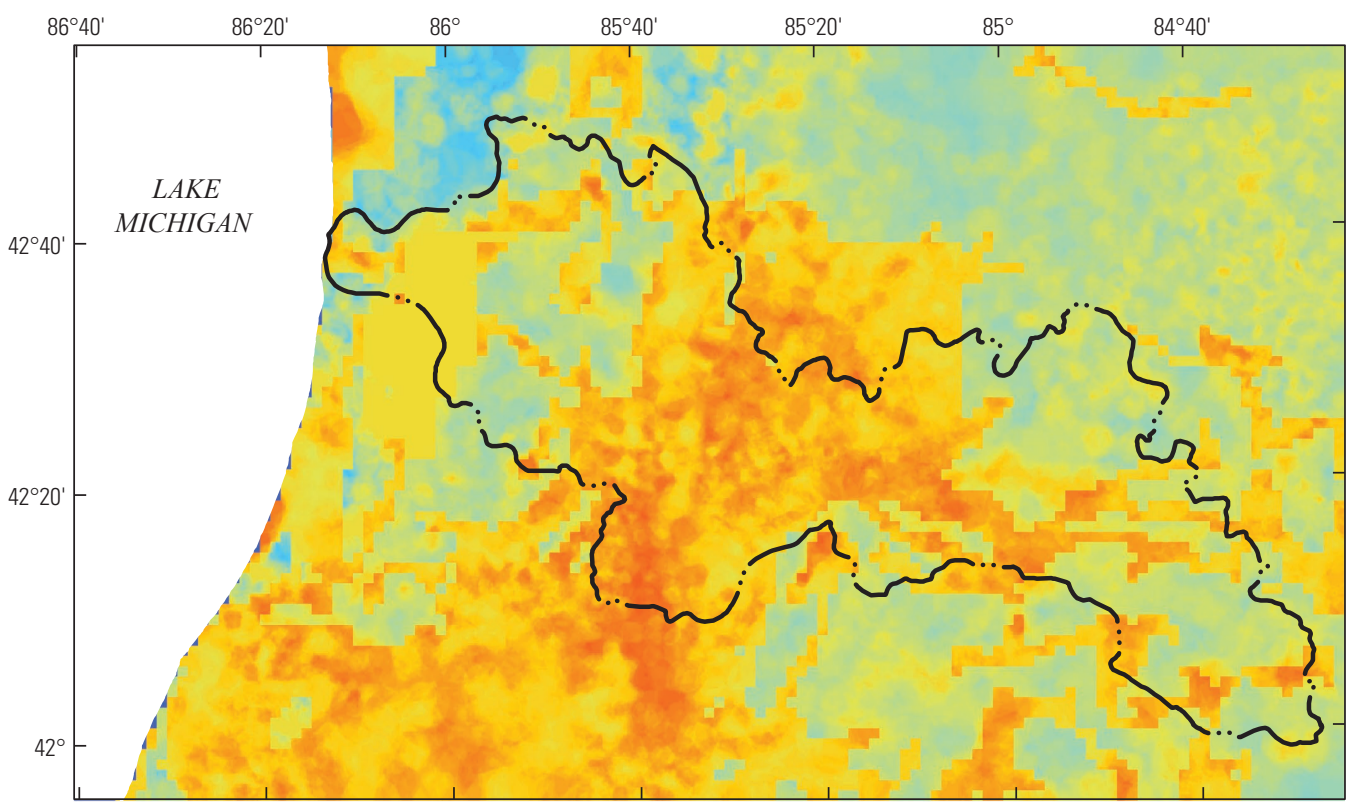

Base from U.S. Geological Survey, 2006, 1:250,000-scale digital data

\section{EXPLANATION}

Horizontal hydraulic conductivity, in feet per day
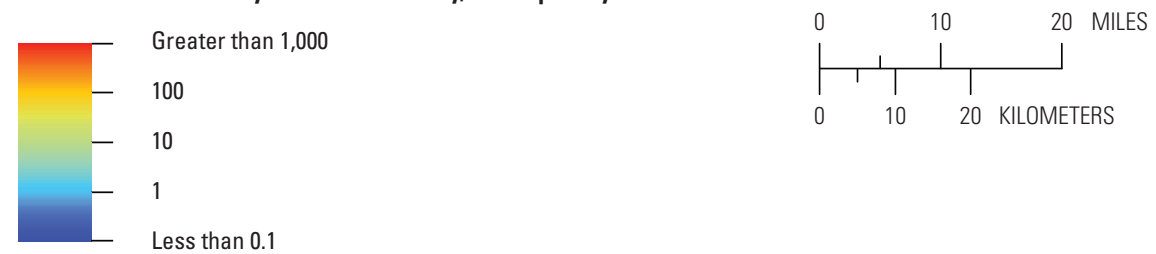

Less than 0.1

Figure 12. Horizontal hydraulic conductivity distributions in layer 1 of the KALA basin. $A$, inherited from the Lake Michigan Basin model at 5,000-foot grid spacing and $B$, updated for the KALA inset model at 500 -foot spacing. 


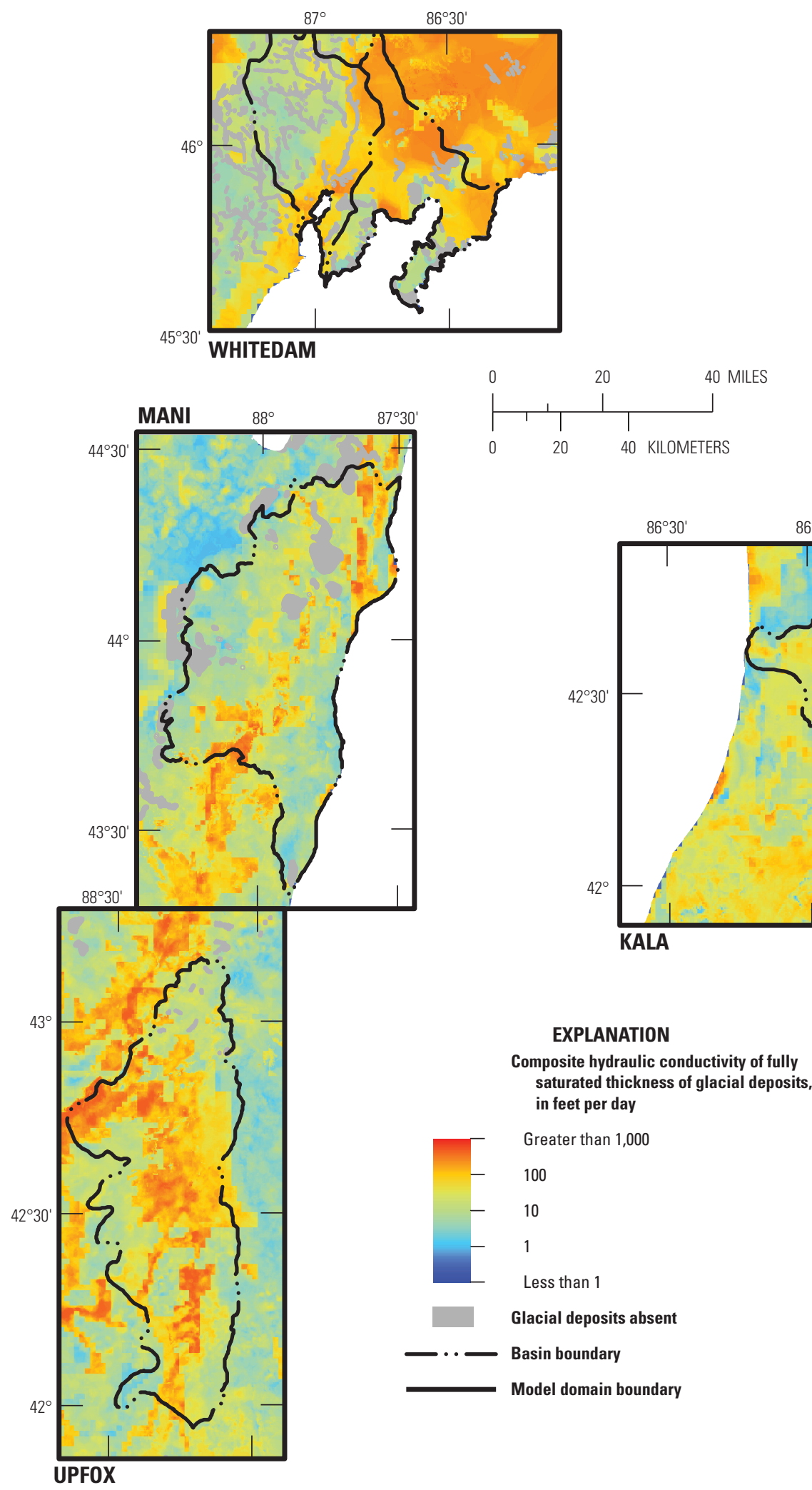

Base from U.S. Geological Survey, 2006, 1:250,000-scale digital data
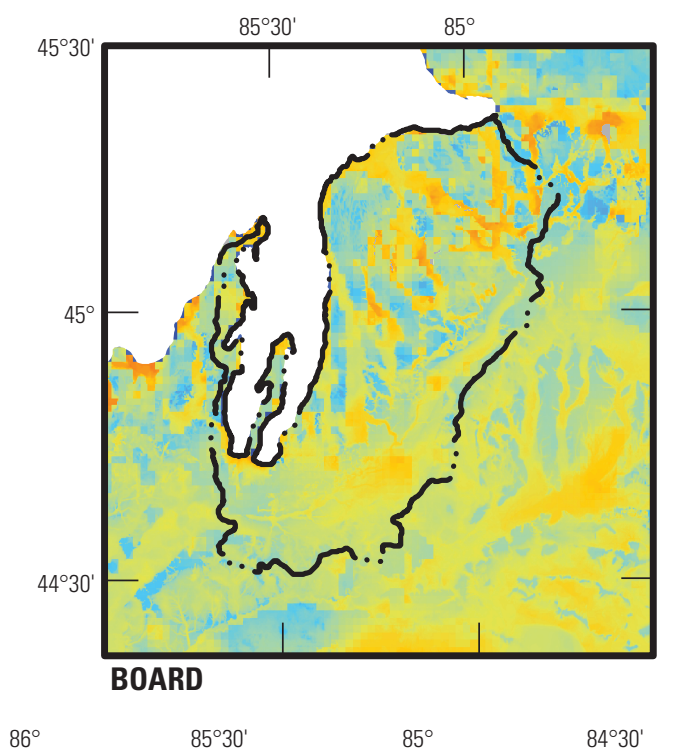
A. Inherited Lake Michigan Basin model surface

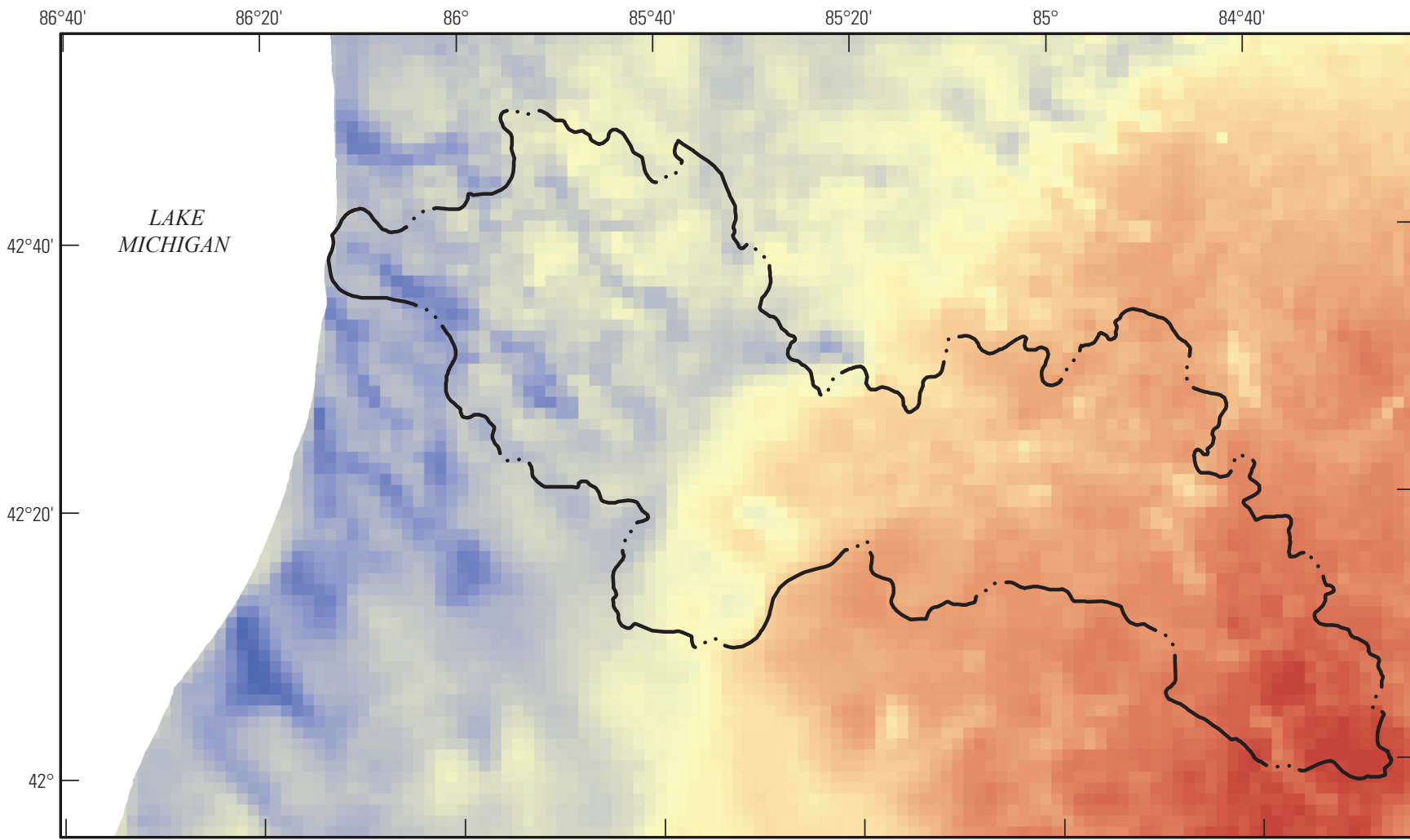

Base from U.S. Geological Survey, 2006, 1:250,000-scale digital data

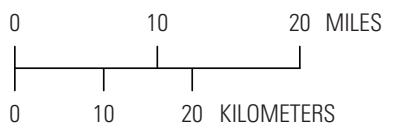

\section{EXPLANATION}

Inherited top of bedrock surface elevation at 5,000-foot grid spacing, in feet above NGVD 29

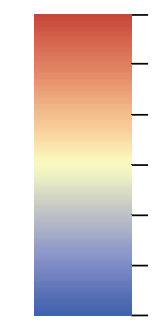

Greater than 1,000

950

800

650

500

350

Less than 200

KALA basin boundary

Figure 14. Top of bedrock surface elevation in KALA inset model. $A$, inherited Lake Michigan Basin model surface at 5,000-foot grid spacing; $B$, adjustments to surface on the basis of log information at 5,000-foot grid spacing; and $C$, adjusted and smoothed inset model surface at 500-foot grid spacing. Surface corresponds to bottom elevation of layer 3 , equivalent to top elevation of layer 4. 
B. Adjustments to KALA model surface

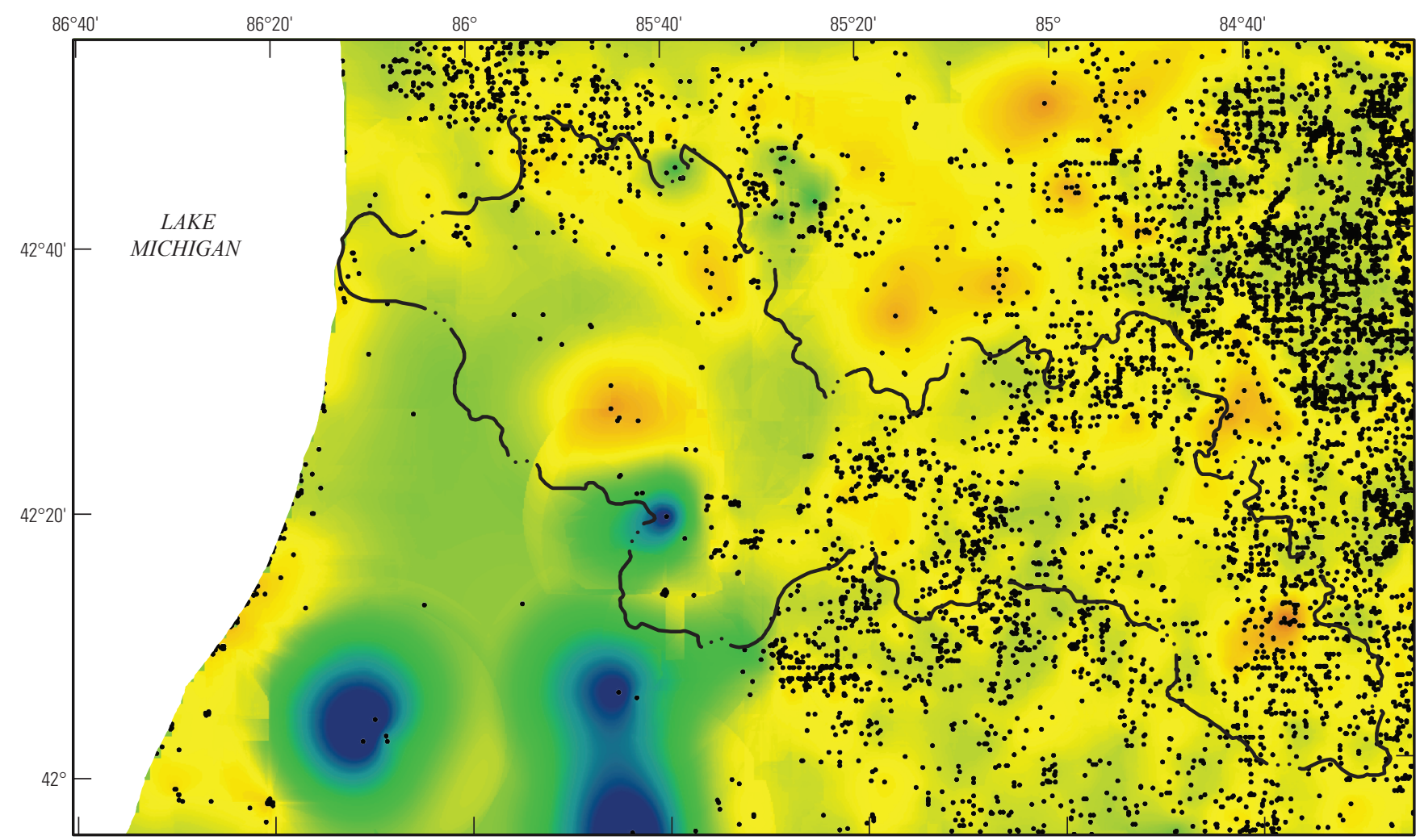

Base from U.S. Geological Survey, 2006, 1:250,000-scale digital data

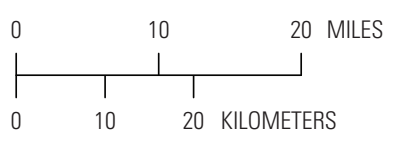

\section{EXPLANATION}

Adjustments to top of bedrock surface elevation at 5,000-foot grid spacing, in feet above NGVD 29

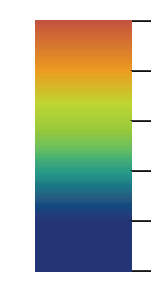

Greater than 100

60

20

$-20$

$-60$

Less than -100

—.. KALA basin boundary

Well with log used to adjust bedrock surface

Figure 14. Top of bedrock surface elevation in KALA inset model. $A$, inherited Lake Michigan Basin model surface at 5,000-foot grid spacing; $B$, adjustments to surface on the basis of log information at 5,000-foot grid spacing; and $C$, adjusted and smoothed inset model surface at 500-foot grid spacing. Surface corresponds to bottom elevation of layer 3 , equivalent to top elevation of layer 4.-Continued 
C. Adjusted and smoothed KALA model surface

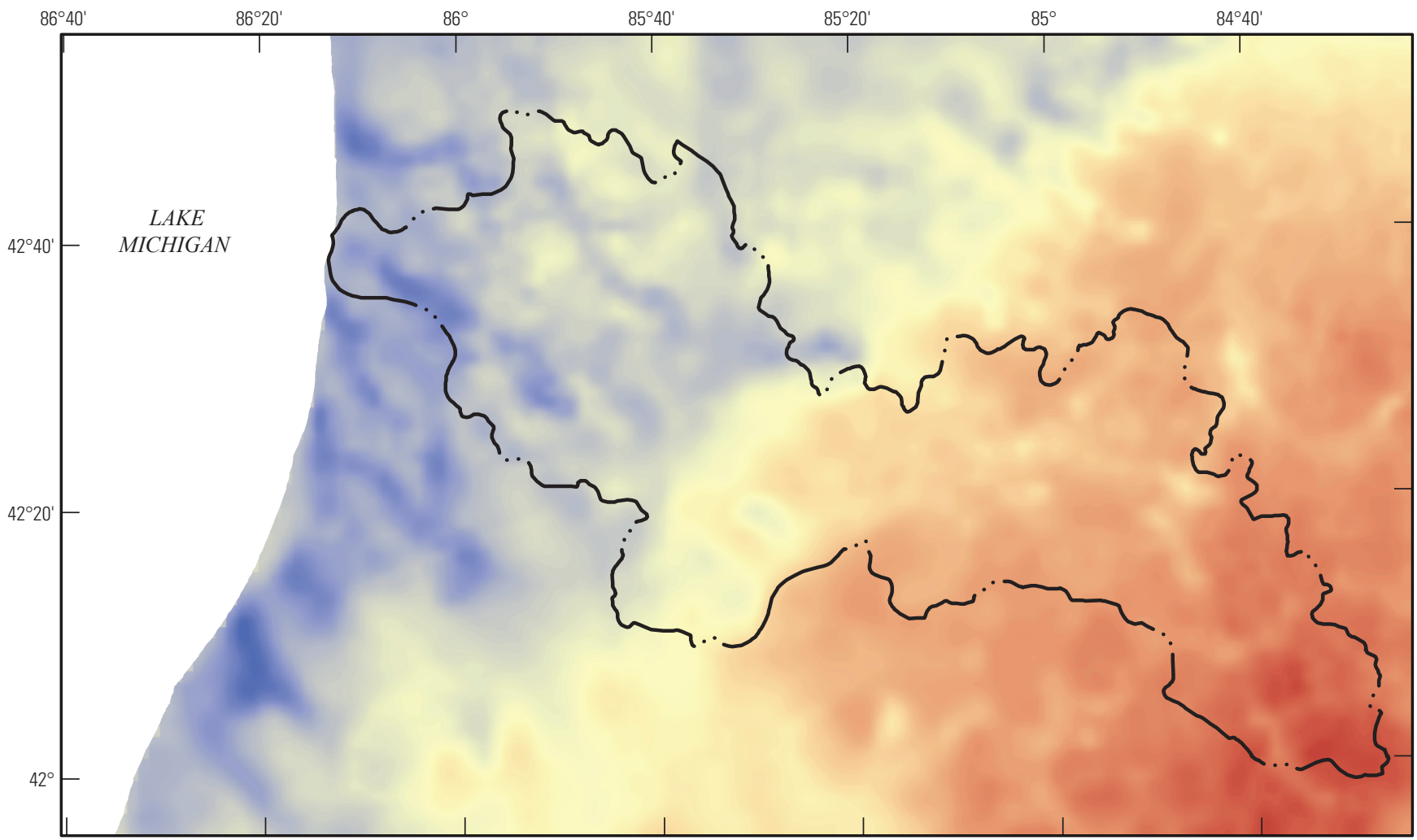

Base from U.S. Geological Survey, 2006, 1:250,000-scale digital data

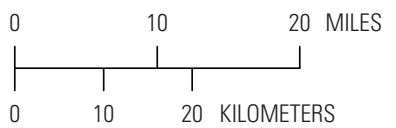

EXPLANATION

Adjusted and smoothed top of bedrock surface elevation at 500-foot grid spacing, in feet above NGVD 29

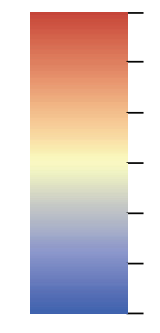

Greater than 1,000

950

800

650

500

350

Less than 200

KALA basin boundary

Figure 14. Top of bedrock surface elevation in KALA inset model. $A$, inherited Lake Michigan Basin model surface at 5,000-foot grid spacing; $B$, adjustments to surface on the basis of log information at 5,000-foot grid spacing; and $C$, adjusted and smoothed inset model surface at 500 -foot grid spacing. Surface corresponds to bottom elevation of layer 3, equivalent to top elevation of layer 4.-Continued 


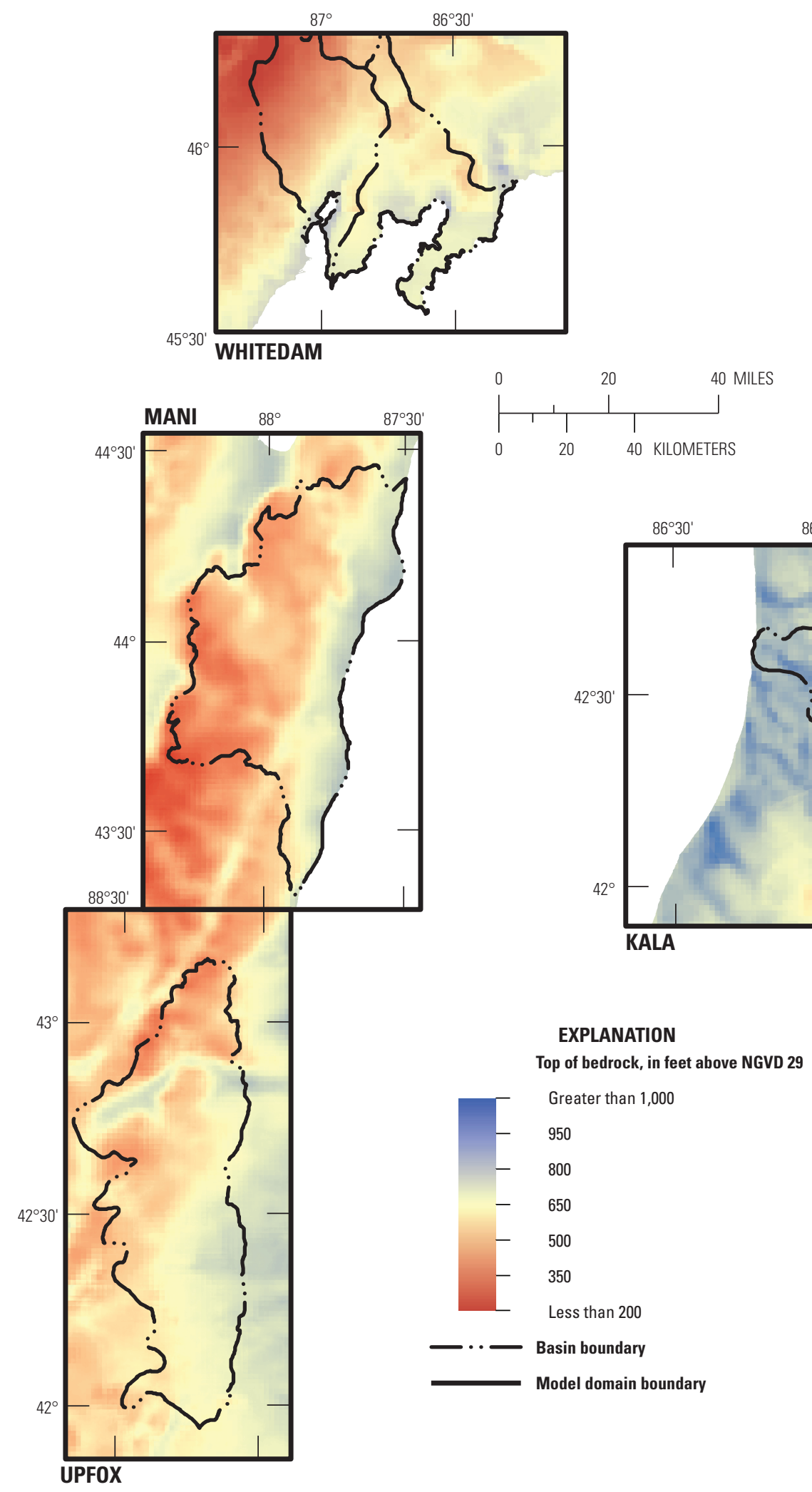

Base from U.S. Geological Survey, 2006, 1:250,000-scale digital data
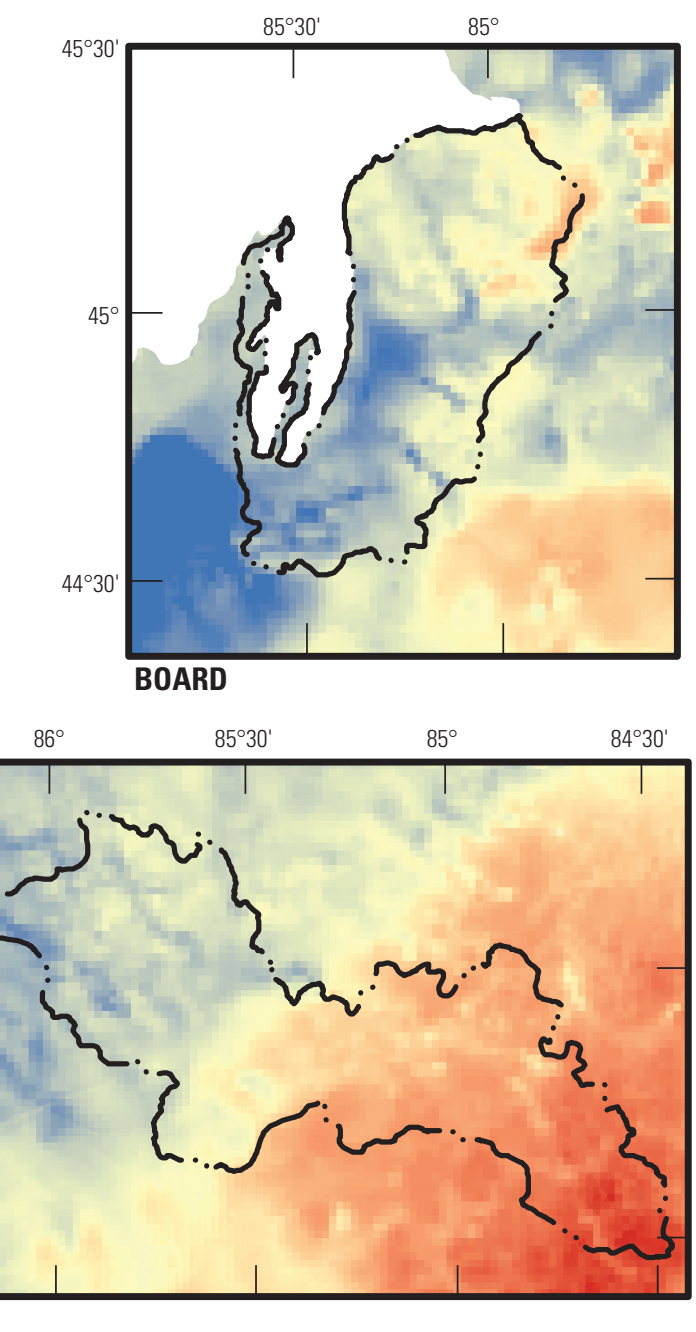

Inset model locations relative to Lake Michigan

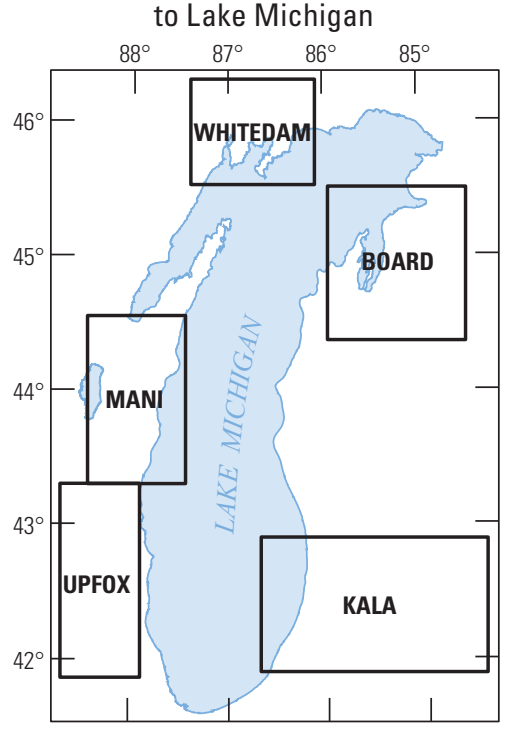

Figure 15. Top of bedrock elevation, corresponding to bottom elevation of layer 3, equivalent to top elevation of layer 4 (all inset models, input). 
total glacial thickness (from land surface to bedrock surface) in the inset models is always greater than that in the LMB model: $569 \mathrm{ft}$ in the KALA model as opposed to $529 \mathrm{ft}$ in the corresponding domain area of the LMB model. The respective maximum glacial thickness value for the BOARD model is $1,089 \mathrm{ft}$ rather than $979 \mathrm{ft}$, for the UPFOX model $441 \mathrm{ft}$ rather than $402 \mathrm{ft}$, for the MANI model $376 \mathrm{ft}$ rather than $321 \mathrm{ft}$, and for the WHITEDAM model $260 \mathrm{ft}$ rather than $207 \mathrm{ft}$. Average total glacial thickness values for the inset model domains and the corresponding area in the LMB parent model are fairly similar: KALA, average is $155 \mathrm{ft}$ as opposed to the corresponding area, $149 \mathrm{ft}$; BOARD, $356 \mathrm{ft}$ as opposed to $335 \mathrm{ft}$; UPFOX, $151 \mathrm{ft}$ as opposed to $155 \mathrm{ft}$; MANI, $103 \mathrm{ft}$ as opposed to $102 \mathrm{ft}$; and WHITEDAM, $40 \mathrm{ft}$ as opposed to $36 \mathrm{ft}$.

Like the LMB model, the inset models are fully threedimensional without gaps between layers (figs. $5 A-E$ ). The refined land surface is the top of the model, but the water-table elevation defines the top of the saturated groundwater system. In figures 16, 17, and 20, model properties are reported relative to saturated aquifer thickness and in terms of the simulated water-table elevation (as in the case of figure 13 where the horizontal hydraulic conductivity in each glacial layer is calculated in terms of saturated rather than total layer thickness).

\section{Refinement of Surface-Water Network}

The parent LMB model employed the MODFLOW RIV (river) package to represent streams and the MODFLOW DRN (drain) package to represent water bodies such as inland lakes and wetlands. The MODFLOW RIV package tends to overestimate the contribution of surface water to shallow wells because the RIV cells always remain active, even if the simulated flow value indicates that there is not sufficient groundwater discharge upstream from a location to yield streamflow in the channel under low-flow conditions. A dry channel, in reality, cannot supply water to wells. The MODFLOW streamflow-routing packages (STR and SFR2) overcome this limitation because they route streamwater downstream on the basis of base-flow accumulation and overland flow added to the channel, accounting for dry reaches.

Streams within the HUC8 basins were simulated with the SFR2 package developed by Niswonger and Prudic (2005). Because each HUC8 basin incorporates an entire basin, the package input includes all the headwater streams in the basin. The KALA model includes streams from 1st to 6th order, the BOARD model from 1st to 5th order, the UPFOX model from 1st to 6th order, the MANI model from 1st to 5th order, and the WHITEDAM model from 1st to 4th order.

The SFR2 package routes water from upstream reaches to downstream reaches to accumulate flow and solve for water level in the stream. Only groundwater discharge to the streams (base flow) is considered in the model simulations. The contribution of overland flow is excluded. In this sense, the result of the simulation corresponds to low-flow conditions in streams, generally during August and September.

Every cell in the MODFLOW model that represents a stream in the SFR2 package is assigned a segment number and a reach number. Reaches represent individual SFR2 cells, which are grouped together into SFR2 segments to facilitate downstream routing of water. The SFR2 package for the inset models was developed from the National Hydrography Plus (NHDPlus) dataset (Bondelid and others, 2010), which guided the locations of stream segments and their downstream connections. Each polyline in the NHDPlus dataset contributed to a separate SFR2 segment containing one or more SFR2 reaches.

The streambed in each cell was assumed to be $1-\mathrm{ft}$ thick, with assumed vertical hydraulic conductivity equal everywhere to $5 \mathrm{ft} / \mathrm{d}$. No effort was made to define areas of relatively high or low bed hydraulic conductivity given the difficulty of assembling the supporting data. For cells with overlapping SFR2 reaches, a hydraulic conductivity of zero was assigned to all reaches except for the one dominant reach that is associated with the highest order stream. The stream length for each SFR2 reach was determined from the length of the associated NHDPlus polyline fragment crossing the model cell. Stream width was calculated as an arbolate sum (Bartošová and others, 2004) on the basis of a relation between measured stream widths and the downstream distance from the headwater origin, as originally developed by Feinstein and others (2010). Elevations of the streambed in each SFR2 reach were derived from the lowest elevation of all values from a 10-meter resolution Digital Elevation Model (U.S. Geological Survey, 2014) that overlapped with the MODFLOW cell containing the associated SFR2 reach. Streambed elevations were subsequently refined, such that all streambed elevations decreased from headwater reaches to the most downstream reach of the stream network. The stream slope and channel roughness, specified as 0.037 for all reaches to correspond to a moderately rough channel (Barnes, 1967), were combined with the stream width and total simulated flow to compute stream stage using Manning's equation for each SFR2 reach (Prudic and others, 2004).

The top of the streambed for most SFR2 cells falls into layer 1 , in the glacial material. However, a proportion of the stream channels are cut into bedrock cells-less than 1 percent of the SFR2 cells for KALA, BOARD, and UPFOX; about 4 percent for MANI; and about 38 percent for WHITEDAM. The streambed hydraulic conductivity assigned to the bedrockincised channels is the same as the value assumed for the channels in unconsolidated material, $5 \mathrm{ft} / \mathrm{d}$.

Outside the HUC8 basins, streams are represented by RIV cells. Their elevations are derived from the 2005 NHDplus dataset, as reported in Bondelid and others (2010), and interpolated to fit the 500-ft grid spacing. The conductance term is calculated in the same way as for the SFR2 cells-a product of assumed bed vertical hydraulic conductivity of $5 \mathrm{ft} / \mathrm{d}$, mapped length from the NHDplus dataset, and estimated width derived from the arbolate sum, then divided by an 


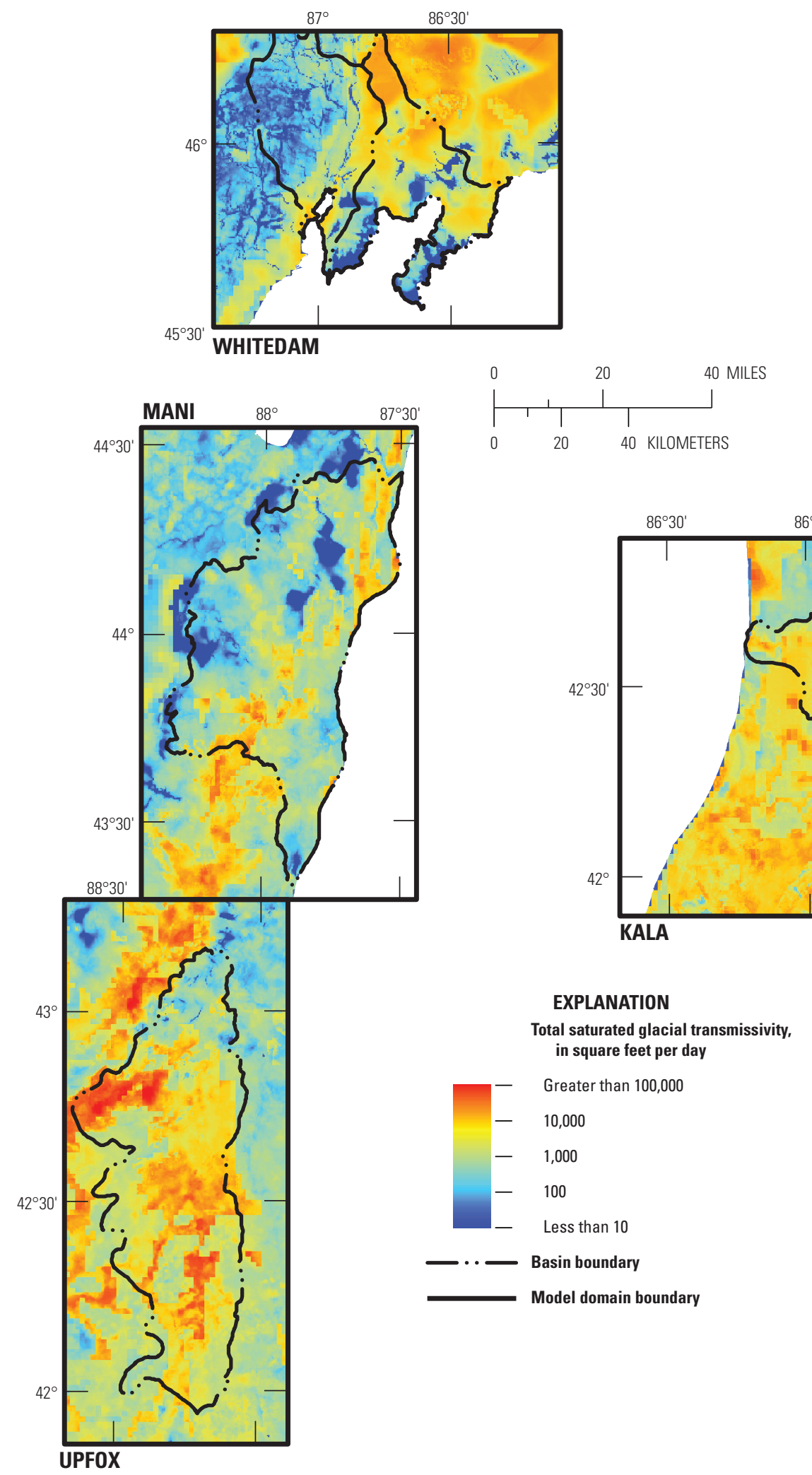

Base from U.S. Geological Survey, 2006, 1:250,000-scale digital data
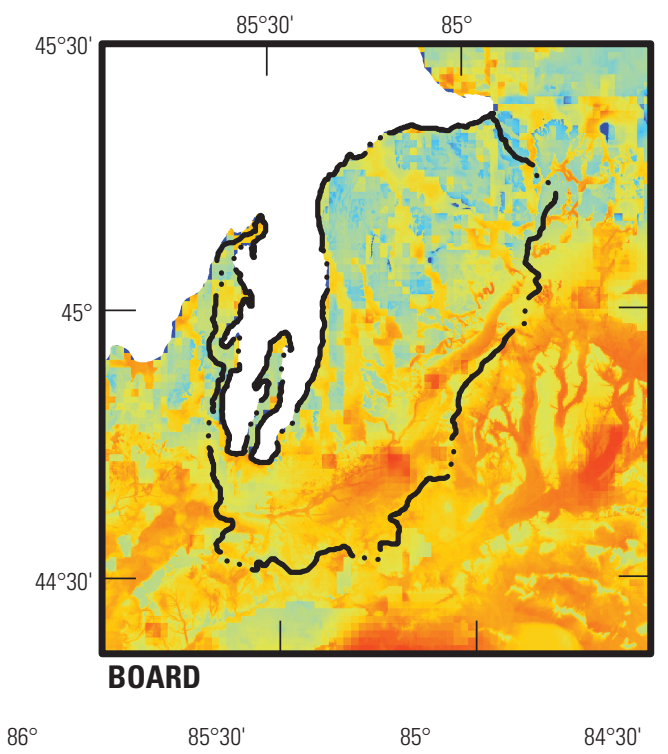


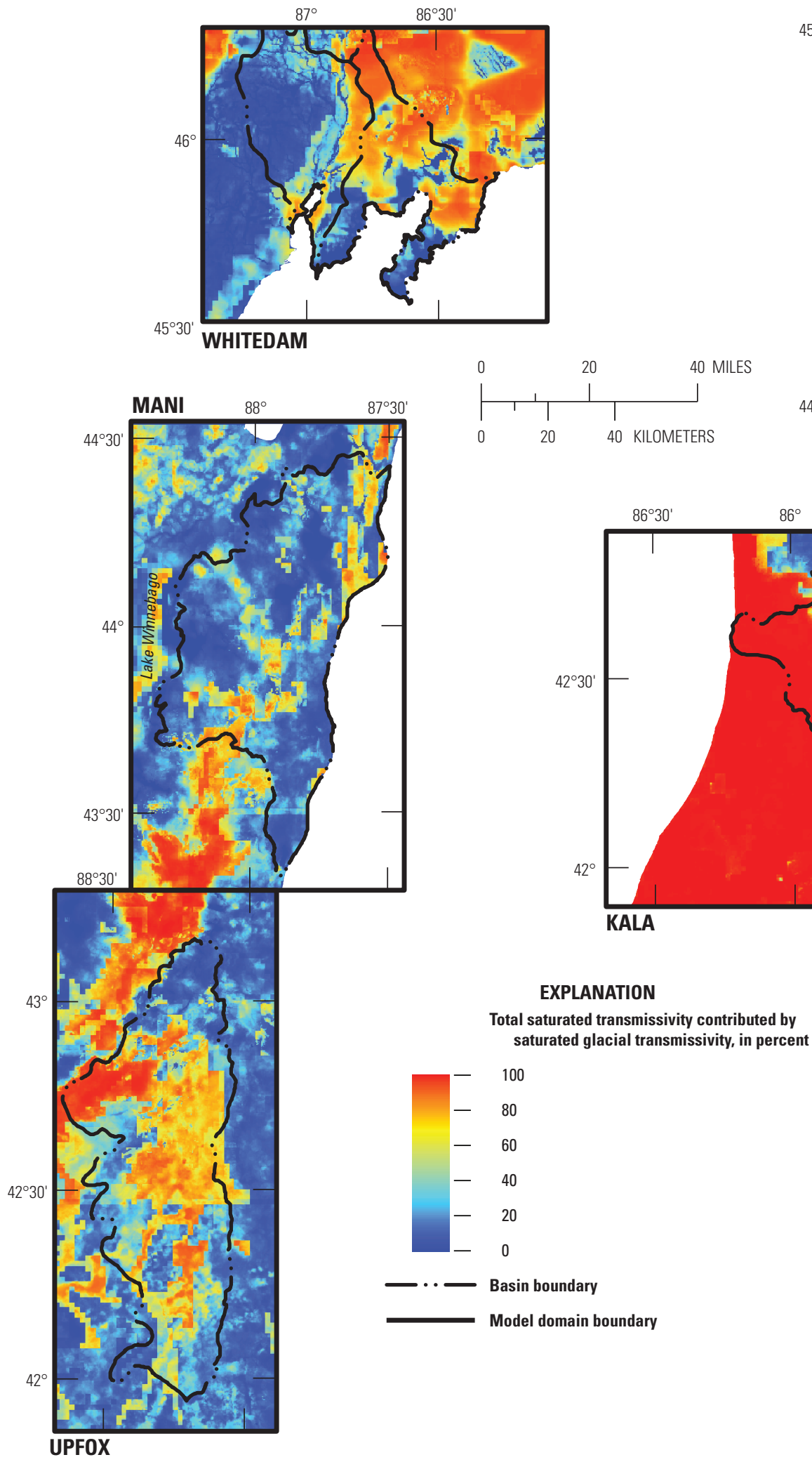

Base from U.S. Geological Survey, 2006, 1:250,000-scale digital data

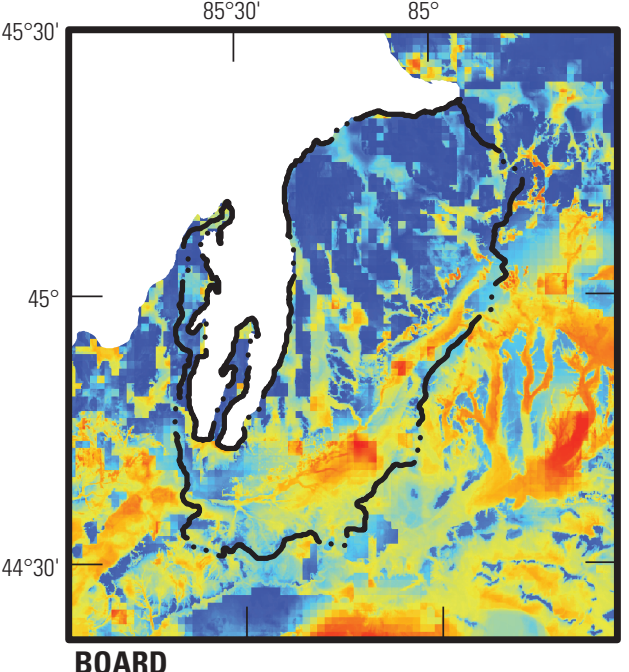
BOARD

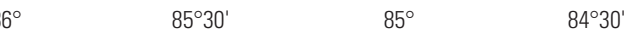


assumed bed thickness of $1 \mathrm{ft}$. RIV cells, particularly in headwater reaches, can supply water to wells even if the simulation indicates they should be considered dry. However, because the RIV cells are present only outside the HUC8 basins, for the purposes of this study, this error is inconsequential.

As in the LMB model (Feinstein and others, 2010, section 4.5), surface-water bodies larger than 20 acres are included in the inset models (both within and outside the target basins) by means of DRN cells with elevations corresponding to the 2005 NHDplus dataset (Bondelid and others, 2010). DRN cells receive only groundwater discharge, they do not lose water to the aquifer system. It is convenient to use the DRN package to represent surface-water bodies in order to avoid perched lakes and wetlands acting as spurious sources of water. The conductance for all drains is set equal to the occupied cell size $\left(250,000 \mathrm{ft}^{2}\right)$ multiplied by an assumed vertical hydraulic conductivity equal to $1 \mathrm{ft} / \mathrm{d}$ divided by an assumed bed thickness of $1 \mathrm{ft}$. No effort was made to distinguish areas with relatively high or low bed conductance, given the difficulty of assembling the supporting data.

In many areas of the inset models, the NHDplus dataset routes streams through surface-water bodies. In other areas, streams are contiguous to surface-water bodies. The spatial juxtaposition of SFR2 and DRN cells can produce spurious circulation to the aquifer when the computed SFR2 water level is different from the DRN elevation, both of which are imprinted by the MODFLOW solution on the simulated water tables in the occupied cells. In particular, the juxtaposition of SFR and DRN cells can produce exaggerated loss from SFR2 cells in one part of the domain and exaggerated gain in another. To avoid such boundary condition artifacts, the bed hydraulic conductivity of SFR2 cells was set to near zero $(1 \mathrm{e}-6 \mathrm{ft} / \mathrm{d})$ when the cells were contiguous laterally or diagonally to a DRN cell. In this way the "sealed" SFR2 cell exchanges very little water with the groundwater system but still serves to route base flow downstream.

The inset models differ in the density of the surfacewater network they contain. Table 2 lists the percentage of targeted HUC 8 basins hosted by SFR2 cells, the percentage of the domain outside the basins hosted by RIV cells, and the percentage of the entire domain hosted by DRN cells. The WHITEDAM inset model is an extreme case; it contains relatively few streams but many surface-water bodies (mostly wetlands).

Figures $3 A-E$ presents spatial representations of the surface-water boundary conditions for each inset model. All RIV cells remain active in the model simulations, but some of the SFR and DRN cells shown in figure 3 are rendered inactive when there is no simulated base flow in a stream or when the water level in a surface-water body is above the simulated water table.

\section{Summary of Input to Inset Models}

The inset models share the 11 MODFLOW input packages listed in table 6. The Basic 6 (BAS) package initializes model settings (including the distribution of inactive cells), and the Discretization (DIS) package contains the grid spacing and layer information. The Upstream Weighted Flow (UPW) package assembles the hydraulic conductivity arrays (there are no storage arrays because the models are steady state). The inland surface-water features are represented by the SFR2, DRN, and RIV packages, as described previously. Lake Michigan (as well as Lake Winnebago in the MANI model) is represented by the GHB package. All existing glacial and bedrock high-capacity wells are represented by the Multi-Node Well 2 (MNW2) package (Konikow and others, 2009) which allows for multi-layer wells in the glacial and bedrock layers. The borehole radius, skin radius, and skin hydraulic conductivity for all existing wells are set at $0.5 \mathrm{ft}, 1.0 \mathrm{ft}$, and $50 \mathrm{ft} / \mathrm{d}$, respectively. These settings assume small well-head loss at the borehole face. Recharge to the water table is input through the Recharge ( $\mathrm{RCH})$ package. Output options are selected using the Output Control (OC) file. Finally, the NWT package defines the parameters for the Newton-Raphson Solver inner and outer iterations. The outer iteration head and flux solver tolerances are uniformly set to $0.01 \mathrm{ft}$ and 10 cubic feet per day, respectively. The inner linear simulation method selected for MODFLOW-NWT (Niswonger and others, 2011) is the XMD solver with CGSTAB acceleration, and inner iteration head closure is set to $0.001 \mathrm{ft}$. Among the general solver settings, the learning rate reduction factor is set to 0.7 , the learning rate increment to 0.1 , the memory term factor to 0.2 , and the momentum term to 0.001 . Backtracking for residual control is active.

The inset model domains, boundary conditions, hydrostratigraphy, glacial no-flow cells, recharge, composite glacial hydraulic conductivity, and top of bedrock elevation are

Table 6. MODFLOW input packages for base inset models.

\begin{tabular}{ll}
\hline \multicolumn{1}{c}{ Description } & File extension \\
\hline Basic 6 & BAS \\
Discretization & DIS \\
Upstream Weighted Flow & UPW \\
Multi-Node Well 2 & MNW2 \\
Streamflow Routing 2 & SFR \\
Drain & DRN \\
River & RIV \\
General Head Boundary & GHB* \\
Recharge & RCH \\
Output Control & OC \\
Newton-Raphson Solver & NWT \\
\hline
\end{tabular}

\footnotetext{
*The GHB package is empty for the UPFOX inset model.
} 
shown in figures $2,3,5,6,7,13$, and 15 , respectively. For the ensemble of inset models, the saturated glacial thickness and hydraulic conductivity inputs together indicate the saturated glacial transmissivity (fig. 16) and the percent of total saturated transmissivity contributed by saturated glacial transmissivity (fig. 17). It is noteworthy that the magnitude of the saturated glacial transmissivity and its contribution to total saturated transmissivity vary widely within inset model domains as well as across them. It is an open question, one which can possibly be addressed with statistical modeling, how this variability affects traveltimes of groundwater flow to shallow wells.

Stream density may also be a factor that affects the groundwater age of shallow well water. In general, higher active stream density yields shorter shallow pathlines. The minimum distance to an active surface-water feature for all inset models is shown in figure 18. Active streams are those with water in the channel from groundwater discharge, according to the model result.

\section{Inset Model Results}

The inset models were solved with the groundwater flow code MODFLOW-NWT (Niswonger and others, 2011), version 1.0.9.0, released July 7, 2014. MODFLOW-NWT is designed, in part, to address challenges caused by modeling sometimes thin unconfined aquifers (common in glaciated regions) that are susceptible to oscillatory dry-cell problems. All models were run under steady-state conditions with stress inputs (recharge and pumping), corresponding to the 2001-5 conditions in the parent LMB model. The inset models were run as constructed without an intervening calibration step. The justification for omitting calibration is presented in the "Model Limitations" section.

The active surface-water networks resolved by the inset models reflect streams that are flowing and water bodies that are in connection with the water table under steady-state conditions. Steady-state conditions effectively represent low-flow conditions where base flow from groundwater is the dominant input to the surface-water network. The active streams (flowing SFR2 cells) and active water bodies (discharging DRN cells) can be interpreted as "perennial" surface-water features, whereas the inactive features can be interpreted as "intermittent" features.

\section{Water Levels}

The water table defines the top of the groundwater system for each inset model. The gradients present at the water table are a major driver for flow conditions in the glacial part of the system. The simulated water-table elevations for all inset models are shown in figure 19. The trends from higher to lower hydraulic head determine the lateral component of flow at the water table (given that the horizontal hydraulic conductivity is assumed to be the same in all lateral directions). Comparison of these simulated water levels (fig. 19) to those from the LMB model (fig. 2) reveals that the LMB model and inset models produce similar flow conditions at the top of the groundwater system. However, the refinement of the inset model grid and input allow for a more precise simulation of conditions around discharge elements such as glacial wells and routed streams. Consider, for example, a shallow well within a 0.5 mile (mi) of a surface-water feature. At the 500 -ft grid spacing, the cone of depression around the well can be approximated with some definition, whereas at the 5,000-ft grid spacing that well falls in the same cell as the stream or water body; therefore, its drawdown is not well simulated (see Feinstein and others, 2016.)

The simulated water levels in the glacial and shallow bedrock units can be viewed from several angles. The saturated glacial thickness is a function of the water-table elevation and the elevation of the top bedrock surface (fig. 20). The depth to the water table is a function of the water-table elevation (fig. 21) and the land-surface elevation. The direction and magnitude of the vertical flow between the glacial deposits and bedrock can be expressed as a function of the head difference between the water table and the water level in the top bedrock aquifer. Areas of upward head difference are evident around major streams; areas of downward head difference are most pronounced in parts of the WHITEDAM, MANI, and northern parts of the UPFOX models. Where vertical flow is prominent, the time of flow can be increased, potentially affecting the age of water converging on shallow wells. Elsewhere, flow in the glacial deposits is predominantly horizontal (fig. 22). Collectively, figures 19-22 show the range of water-level conditions for the glaciated terrain represented by the five inset models in response to the steady-state recharge, boundary conditions, and pumping conditions derived from the 2001-5 stress period of the LMB model. The range in head conditions affects the range of ages reported in section "Application of Inset Models to Calculate Age Distribution in Groundwater Discharge to Glacial Wells."

\section{Stream Base-Flow Conditions}

The MODFLOW-NWT simulation determines the SFR2 reaches that transmit base flow and are, therefore, considered active. Recall that the SFR2 reaches are restricted to the target HUC8 basins for each model. The percentages of each stream order that is active are listed in table 7 . In all the inset model basins, the ratio of active to total first-order (headwater) reaches is appreciably smaller than the ratio for higher orders. It is expected that headwater reaches are much more likely to be intermittent than higher order reaches. Active first-order streams, which are also those most vulnerable to depletion by increased shallow pumping, represent 40 percent of all active SFR2 cells for the KALA basin, 37 percent for the BOARD and UPFOX basins, 33 percent for the MANI basin, and 57 percent for the WHITEDAM basin (this last model has 


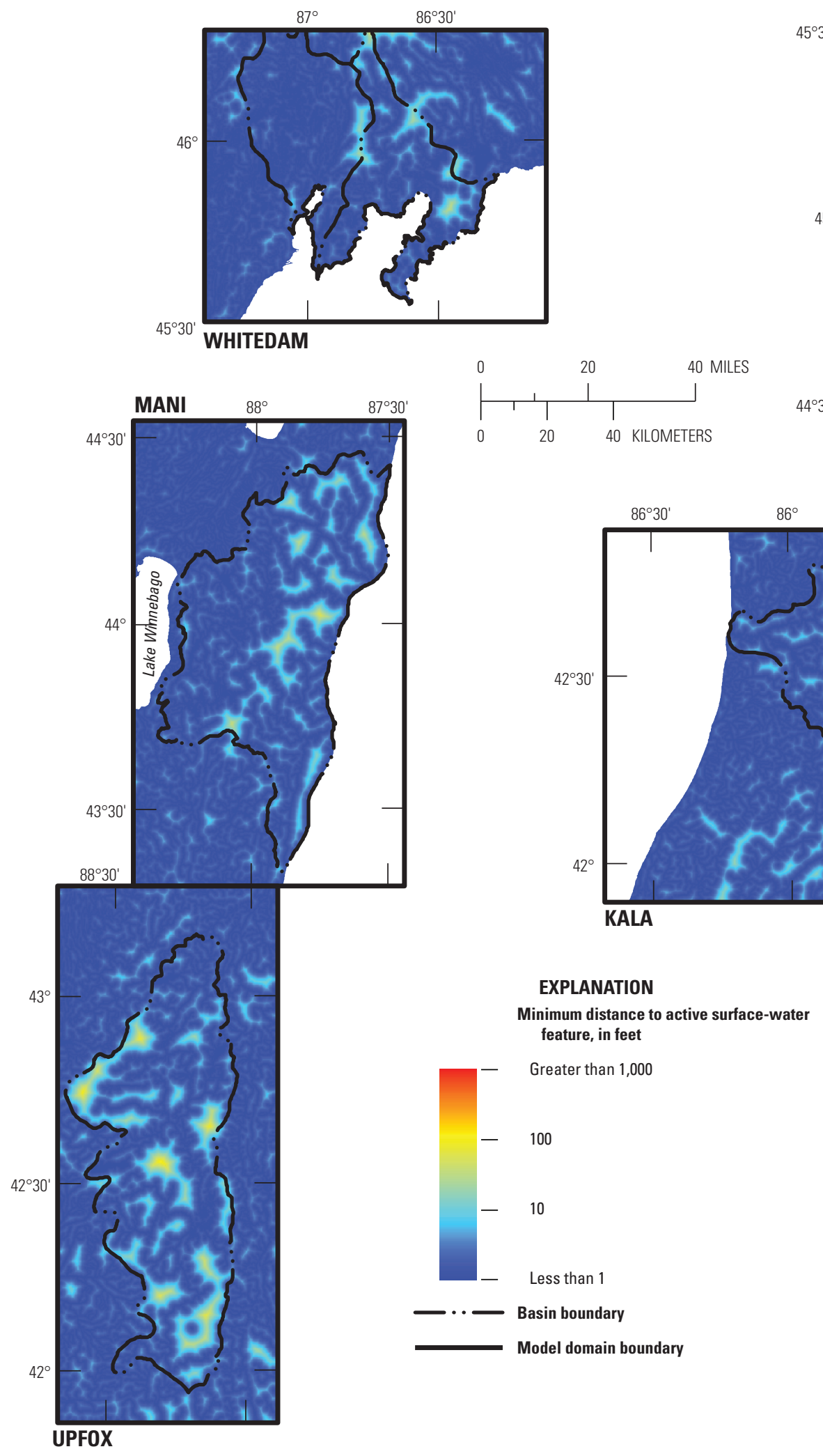

Base from U.S. Geological Survey, 2006, 1:250,000-scale digital data

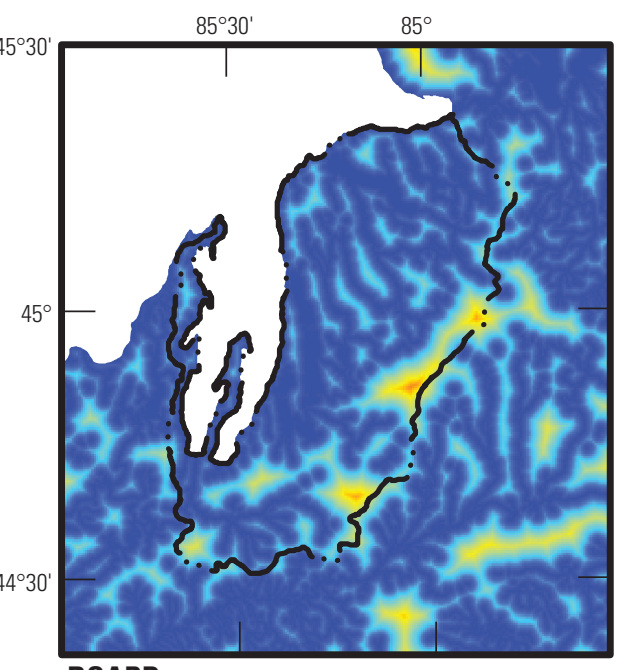

BOARD

$84^{\circ} 30^{\prime}$ 

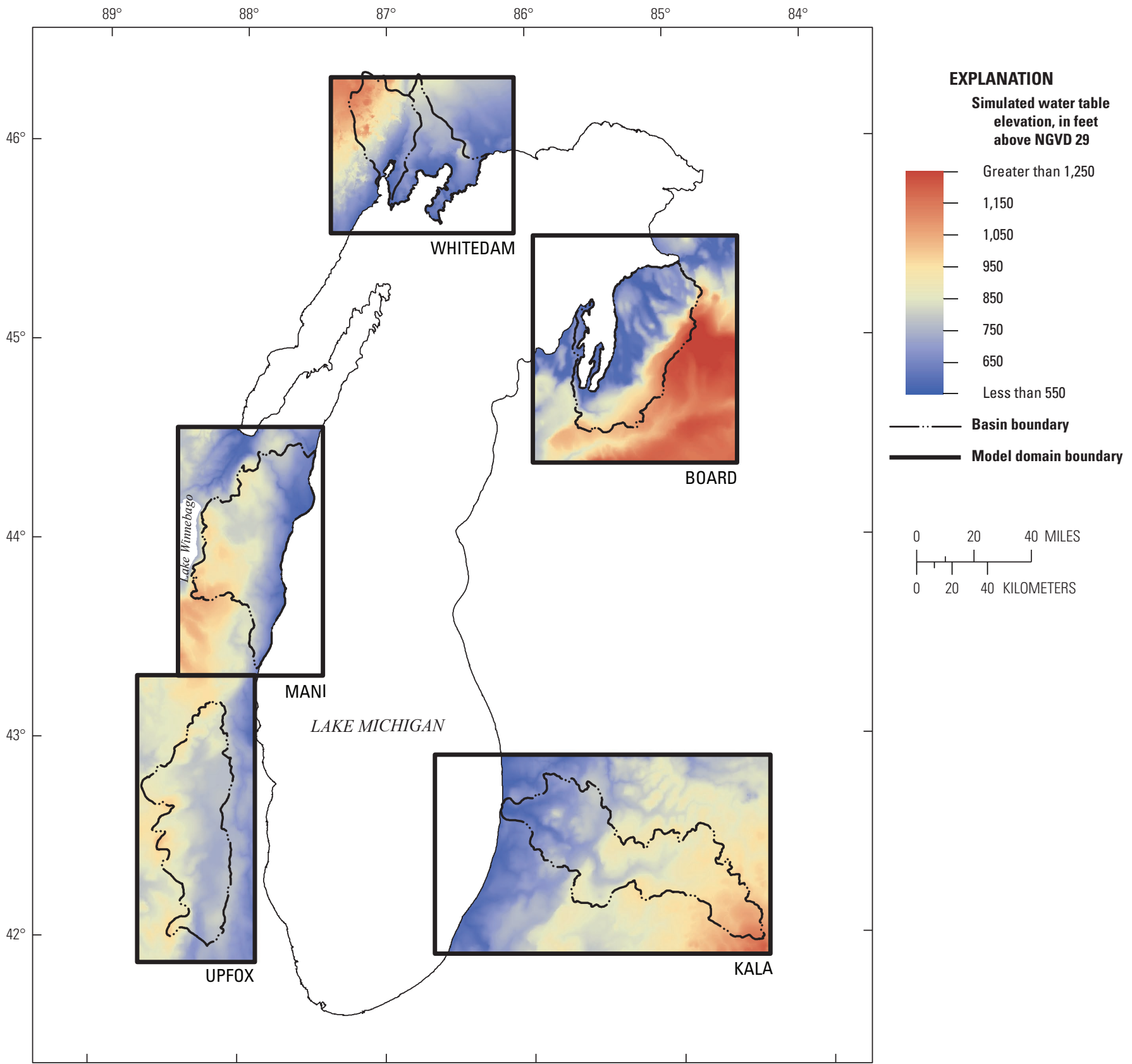

Base from U.S. Geological Survey, 2006,

1:250,000-scale digital data

Figure 19. Simulated water-table elevation (all inset models, output). 


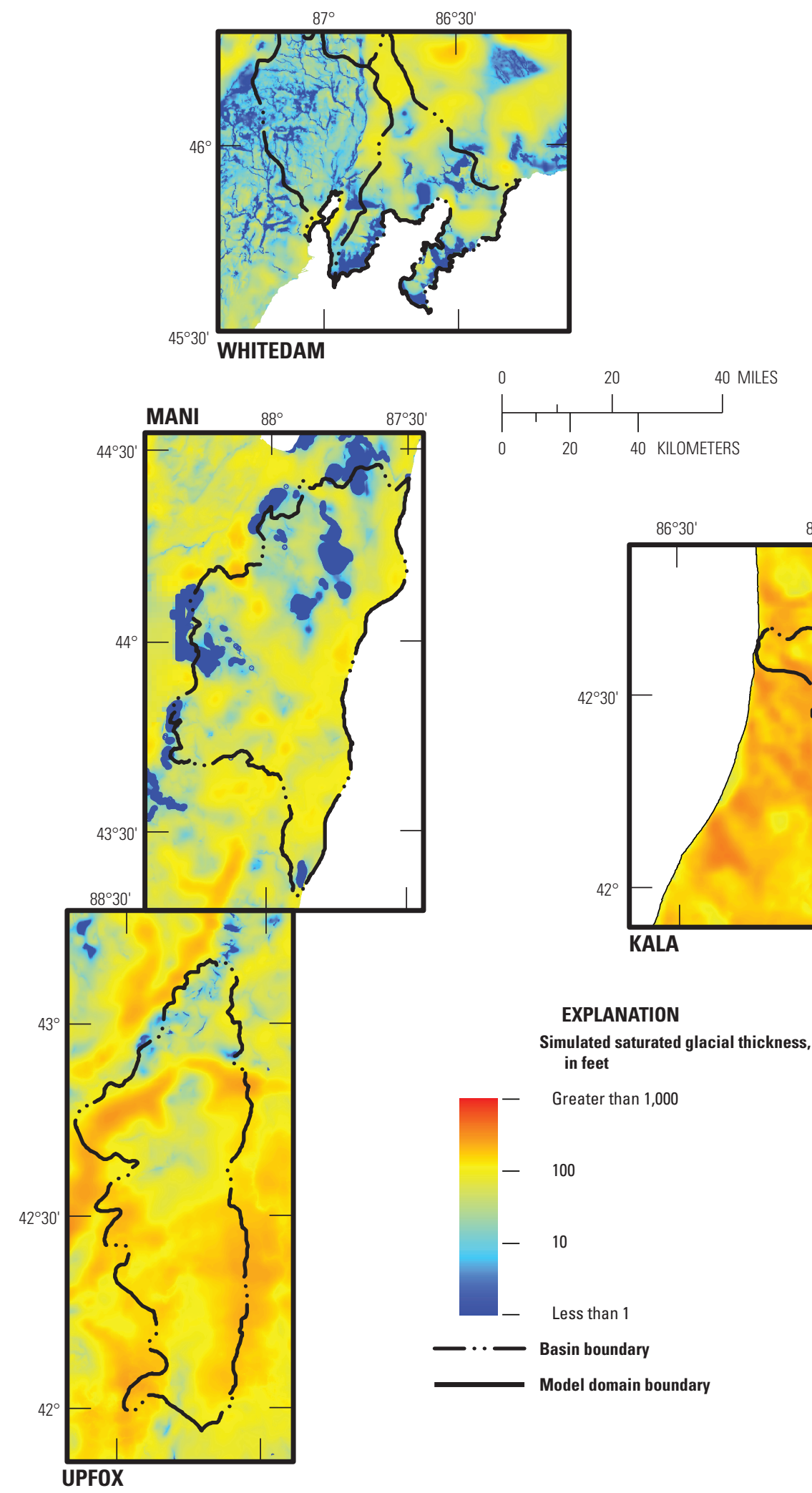

Base from U.S. Geological Survey, 2006, 1:250,000-scale digital data

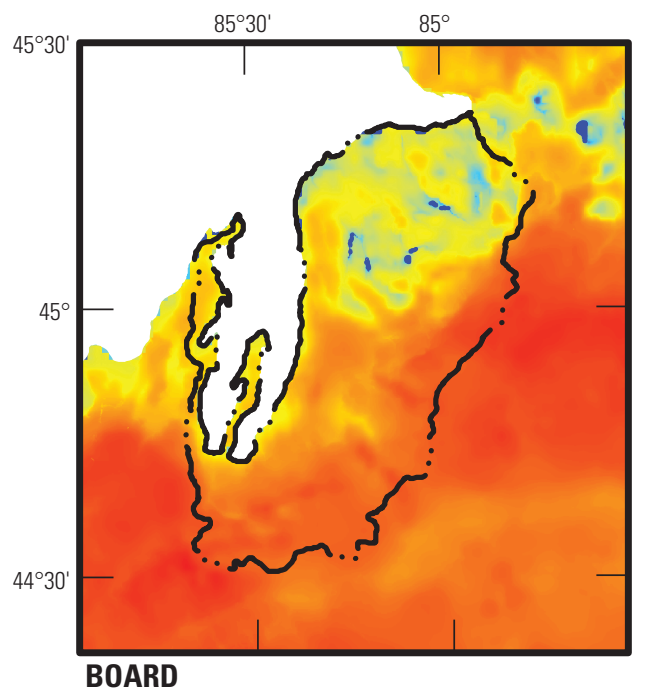

$\begin{array}{llll}86^{\circ} & 85^{\circ} 30^{\circ} & 85^{\circ} & 84^{\circ} 30^{\prime}\end{array}$

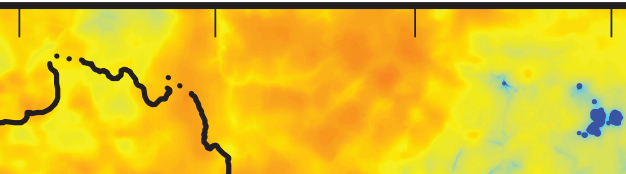



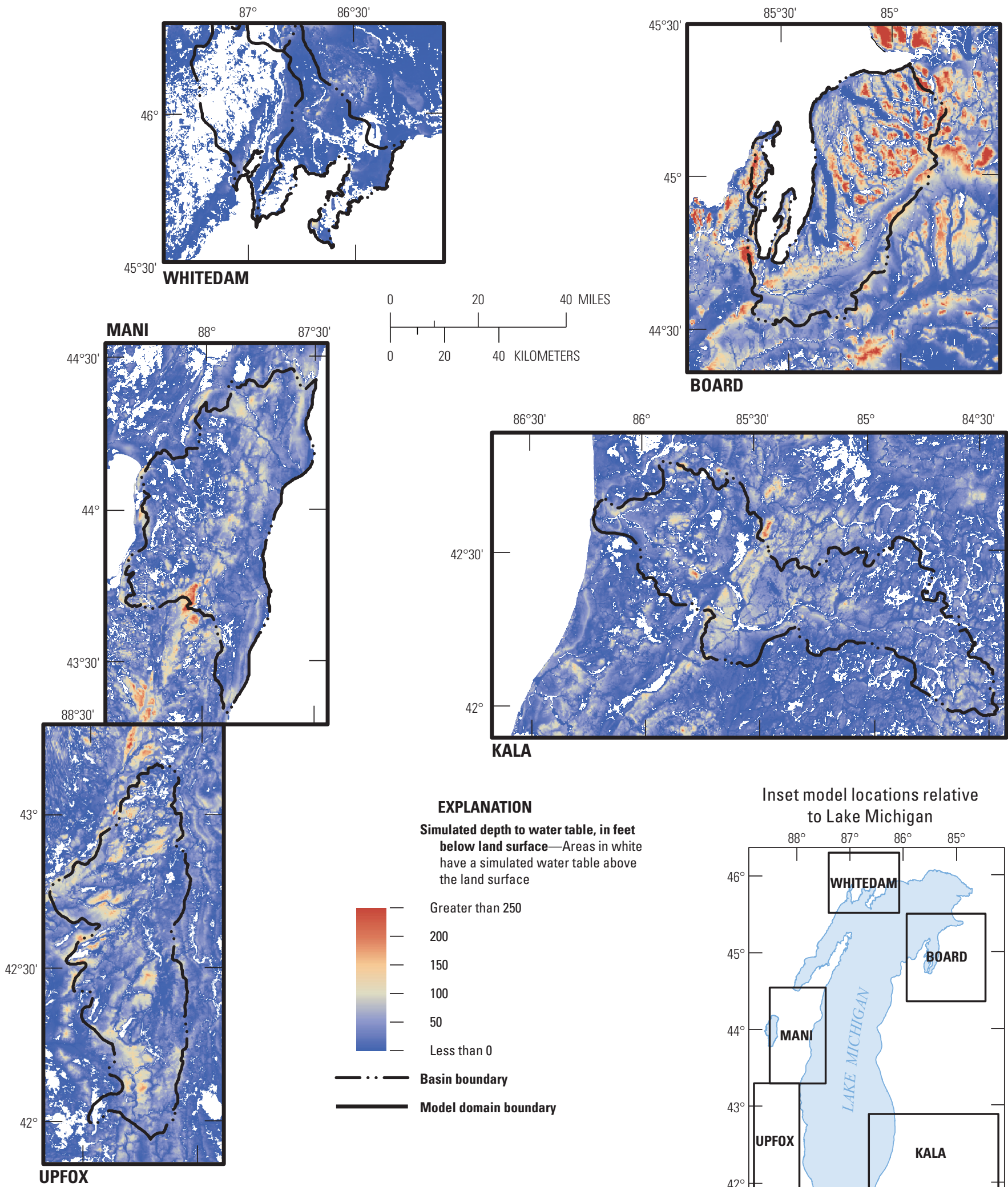

Base from U.S. Geological Survey, 2006, 1:250,000-scale digital data

Inset model locations relative to Lake Michigan

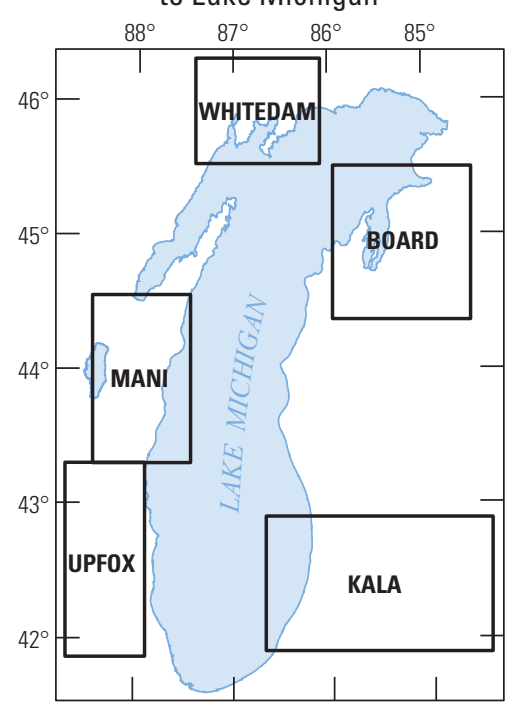

Figure 21. Simulated depth to water table below the land surface in top layer cells (all inset models, output). 


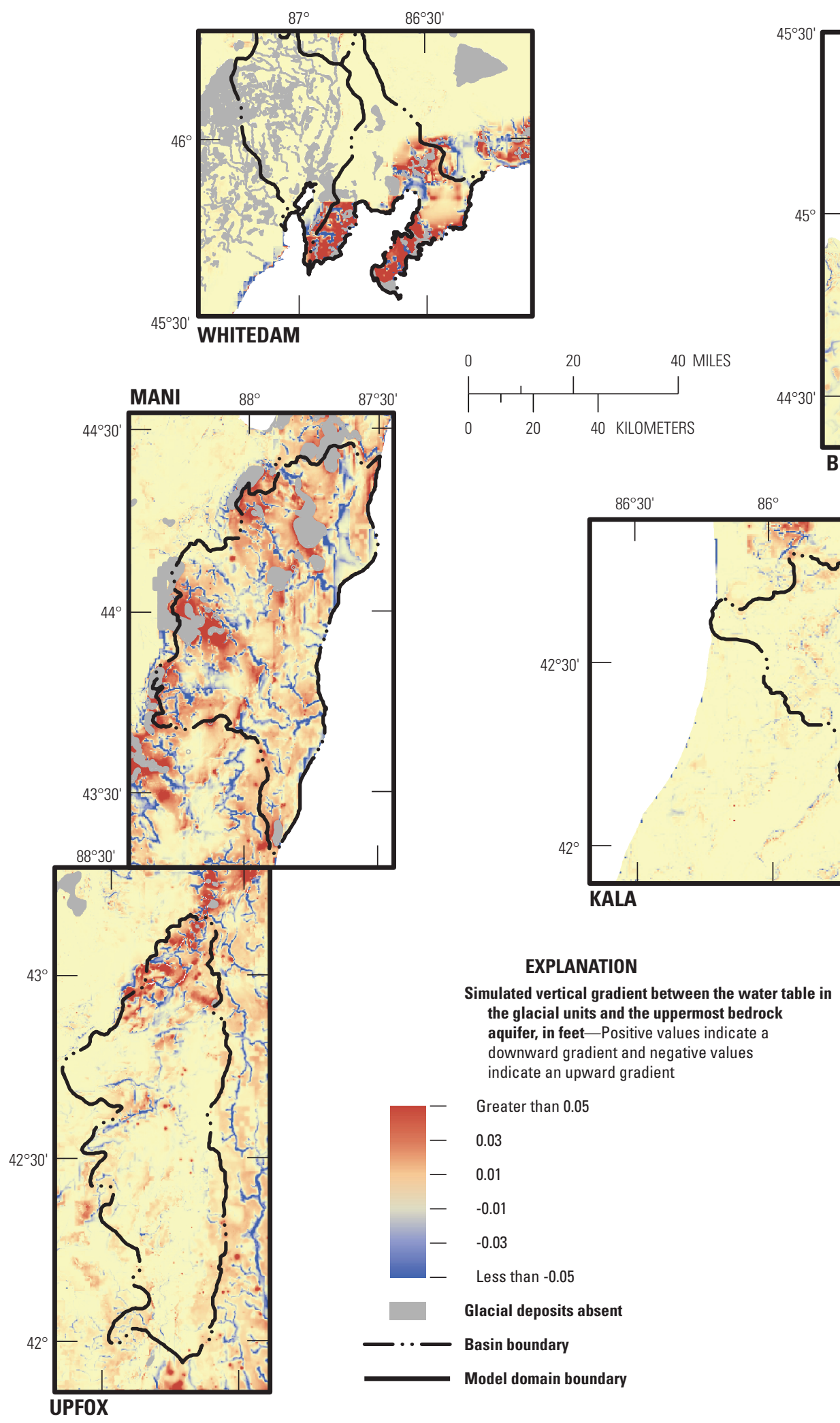

Base from U.S. Geological Survey, 2006, 1:250,000-scale digital data

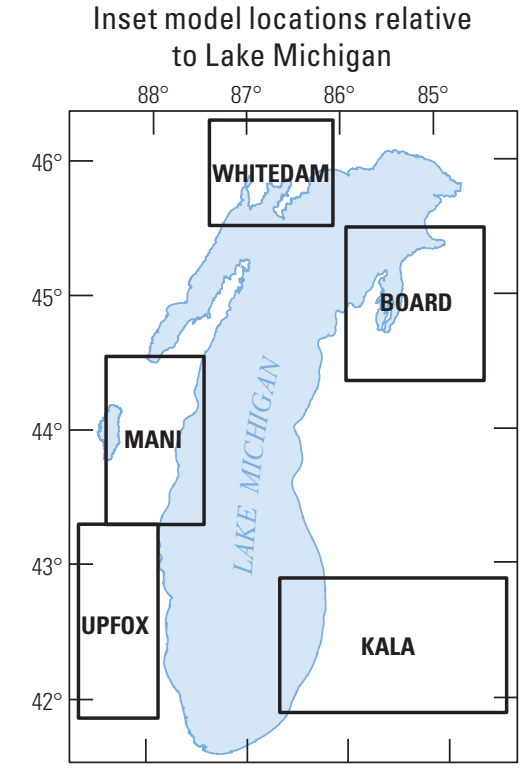

Figure 22. Simulated vertical gradient between the water table in the glacial units and the water level in the uppermost bedrock aquifer (all inset models, output). 
Table 7. Active streamflow routing package (SFR2) cells by stream order for HUC8 basins within inset models.

[Total percent active are calculated for each basin by summing the product of total number of SFR2 cells for each stream order with its percent active, then dividing by total number of SFR2 cells in basin. HUC8, 8-digit hydrologic unit code; $\%$, percent]

\begin{tabular}{|c|c|c|c|}
\hline Inset model & Stream order & $\begin{array}{l}\text { Total number } \\
\text { SFR2 cells }\end{array}$ & $\begin{array}{c}\text { Percent active } \\
(\%)\end{array}$ \\
\hline \multirow[t]{7}{*}{ KALA } & 1 & 9,960 & 48.6 \\
\hline & 2 & 3,246 & 87.6 \\
\hline & 3 & 2,056 & 97.6 \\
\hline & 4 & 1,090 & 100.0 \\
\hline & 5 & 1,243 & 100.0 \\
\hline & 6 & 147 & 100.0 \\
\hline & Total & 17,742 & 68.6 \\
\hline \multirow[t]{6}{*}{ BOARD } & 1 & 6,029 & 31.5 \\
\hline & 2 & 1,720 & 85.4 \\
\hline & 3 & 1,367 & 88.8 \\
\hline & 4 & 478 & 100.0 \\
\hline & 5 & 54 & 100.0 \\
\hline & Total & 9,648 & $\mathbf{5 3 . 0}$ \\
\hline \multirow[t]{7}{*}{ UPFOX } & 1 & 8,974 & 31.5 \\
\hline & 2 & 2,707 & 64.5 \\
\hline & 3 & 1,446 & 93.4 \\
\hline & 4 & 826 & 100.0 \\
\hline & 5 & 185 & 100.0 \\
\hline & 6 & 720 & 100.0 \\
\hline & Total & 14,858 & 51.5 \\
\hline \multirow[t]{6}{*}{ MANI } & 1 & 10,807 & 28.2 \\
\hline & 2 & 3,554 & 68.3 \\
\hline & 3 & 2,267 & 90.1 \\
\hline & 4 & 1,351 & 100.0 \\
\hline & 5 & 407 & 100.0 \\
\hline & Total & 18,386 & 50.5 \\
\hline \multirow[t]{5}{*}{ WHITEDAM } & 1 & 4,388 & 80.2 \\
\hline & 2 & 1,430 & 98.3 \\
\hline & 3 & 1,154 & 99.7 \\
\hline & 4 & 108 & 100.0 \\
\hline & Total & 7,080 & 87.30 \\
\hline
\end{tabular}

the least developed stream network). These percentages are computed from table 7 by multiplying the percent first-order SFR2 cells that are active by their total number and dividing the result by the percent of all SFR2 cells that are active multiplied by their total number.

In part of the network, streams lose flow to the groundwater system because slope and other natural considerations cause an outward gradient from the channel and (or) because pumping from existing wells induces stream loss. Within the KALA basin, 18.5 percent of the active stream cells are simulated to lose flow to groundwater. The corresponding simulated values for the other target basins range fairly widely-BOARD, 32.7 percent; UPFOX, 22.9 percent; MANI, 15.4 percent; and WHITEDAM, 7.5 percent.

\section{Shallow Flow Patterns}

The simulated shallow horizontal and vertical gradients combine with the hydraulic conductivity distribution to produce simulated flow vectors across the various cell faces according to Darcy's law. The face components can be averaged to a single Darcy velocity vector at the cell center which, when divided by an assumed effective porosity, yields the cell advective velocity vector. An assumed effective porosity value of 0.20 for all the glacial deposits generates the velocity field at the water table shown in figure 23 . The variation in the magnitude of the velocity vectors within and among the inset models is evident, ranging over several orders of magnitude.

\section{Basin Water Budgets}

The water budgets for the inset models consist of source components and sink components. The model solutions determine the strength of sources that add water to the saturated system (recharge, losing streams, and constant-head edge boundaries that have higher heads than neighboring cells) and sinks that subtract water from the saturated system (gaining streams, active water bodies, almost all the Lake Michigan shoreline, pumped wells, and constant-head edge boundaries that have lower heads than neighboring cells). In the context of this study, the water budget of interest is for the glacial part of the flow system within the target HUC8 basins. For this part of the flow system, the source components are basin recharge, lateral flow from surrounding basins into the target basin, inflow from losing SFR2 stream cells, upward groundwater flow from the bedrock below the target basin, and any subsurface inflow from Lake Michigan to the target basin. The sink components are discharge to SFR2 stream cells, discharge to the target basin water bodies represented by active DRN cells, lateral flow out of the target basin to surrounding basins, downward flow from glacial deposits to the bedrock below the target basin, groundwater discharge from the target basin to Lake Michigan, and sustained discharge to pumping wells. The sum of the source components is equal to the sum of the sink components, except for a small error dictated by the simulation iteration tolerances.

The fluxes associated with each sink and source components for the target basins, along with the water-budget percent errors, are compiled in table $8 \mathrm{~A}$. To facilitate comparison among the basins, the percent contribution of each source to the total basin inflow and the percent contribution of each sink to the total basin outflow are compiled in table $8 B$. In all basins, recharge is the dominant source. In four of the five models, discharge to SFR2 streams is the dominant sink; 


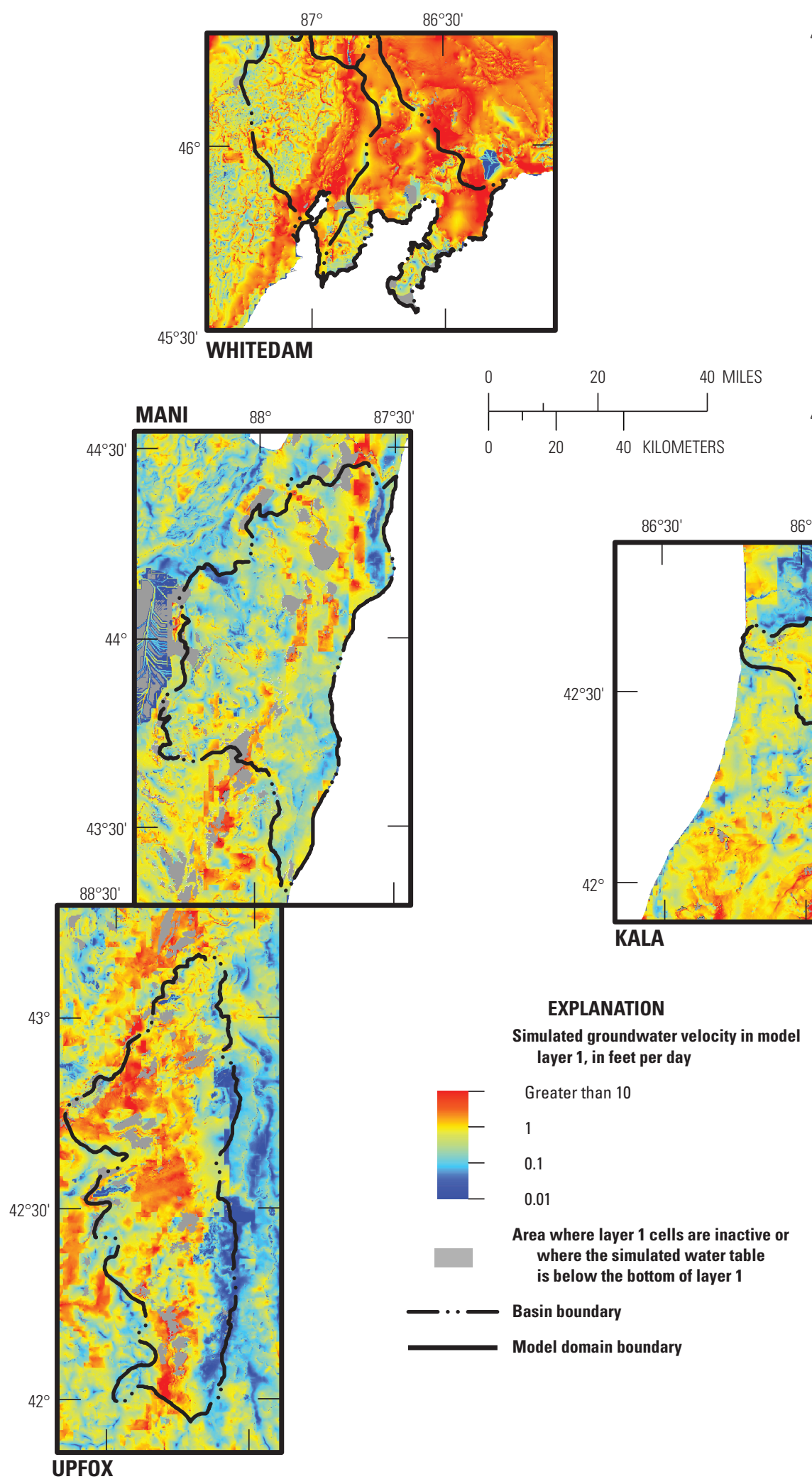

Base from U.S. Geological Survey, 2006, 1:250,000-scale digital data

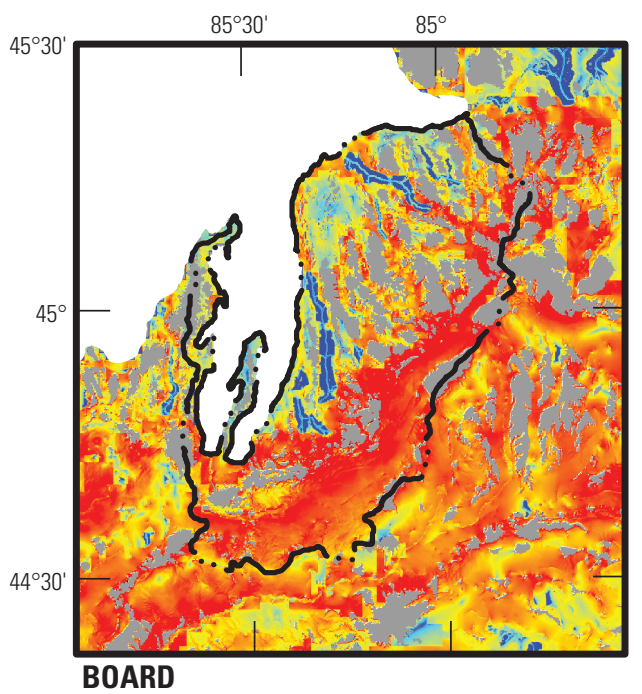

BOARD

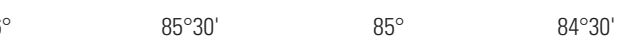


Table 8. Simulated water budgets for target HUC8 basins within all inset models. $A$, source inflows and sink outflows and $B$, source percentages of total inflows and sink percentages of total outflows.

\section{A. Source inflows and sink outflows}

[HUC8, 8-digit hydrologic unit code; $\mathrm{ft}^{3} / \mathrm{s}$, cubic foot per second]

\begin{tabular}{|c|c|c|c|c|c|}
\hline & \multicolumn{5}{|c|}{ Inflows (ft $/ \mathbf{s})$} \\
\hline & KALA & BOARD & UPFOX & MANI & WHITEDAM \\
\hline Recharge to basin & $1,455.5$ & $1,067.1$ & 735.9 & 394.3 & 598.9 \\
\hline Stream loss to groundwater in basin & 157.5 & 93.8 & 125.7 & 37.2 & 4.9 \\
\hline Upward flow from bedrock to glacial deposits in basin & 228.8 & 29.4 & 28.2 & 88.1 & 35.4 \\
\hline \multirow{2}{*}{ Total IN } & \multicolumn{5}{|c|}{ Outflows (ft/s) } \\
\hline & KALA & BOARD & UPFOX & MANI & WHITEDAM \\
\hline Discharge to streams in basin & $1,108.1$ & 596.0 & 536.6 & 258.2 & 154.0 \\
\hline Discharge to water bodies in basin & 397.0 & 569.4 & 255.1 & 81.4 & 341.3 \\
\hline High-capacity glacial well discharge in basin & 74.1 & 7.5 & 37.3 & 2.0 & 0.0 \\
\hline Total OUT & $1,908.2$ & $1,348.4$ & 938.8 & 542.4 & 659.5 \\
\hline $\begin{array}{l}\text { Percent error [equal to } 100 *(\text { INFLOW-OUTFLOW }) / \\
\text { OUTFLOW] }\end{array}$ & -0.000521 & -0.000048 & 0.000028 & -0.000219 & 0.002328 \\
\hline
\end{tabular}

B. Source percentages of total inflows and sink percentages of total outflows

[Total may not sum to 100 percent because of rounding]

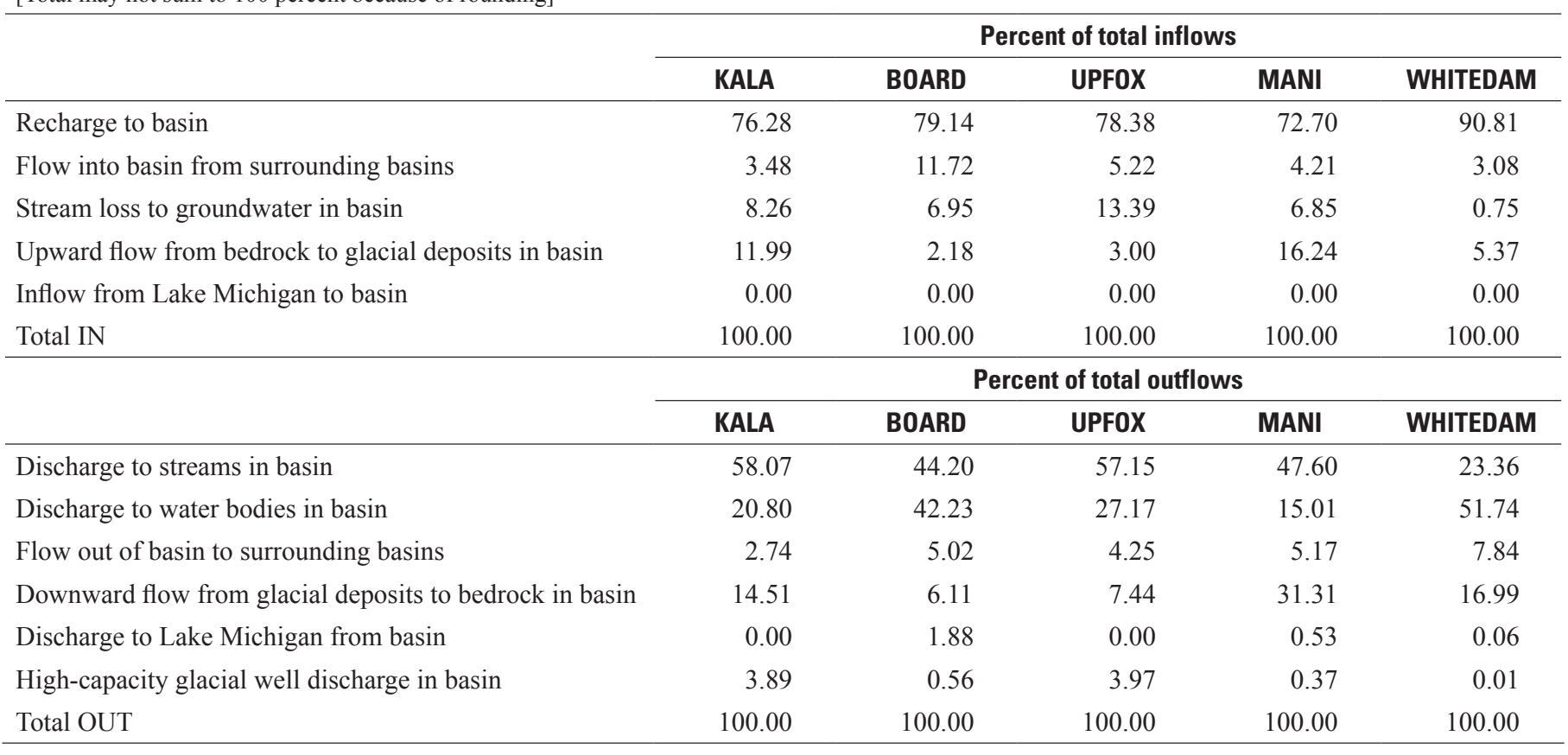


the exception is the WHITEDAM basin where water bodies (largely wetlands) are the dominant sink. The relative importance of sustained pumping from existing glacial high-capacity wells is variable among the basins; it is comparatively high for KALA and UPFOX and low for MANI and WHITEDAM. There is some difference in the relative importance of crossboundary flows among the inset models. The amount of vertical flow between the glacial and bedrock parts of the flow system is highly variable. The relative importance of vertical exchange is greatest for the MANI basin and least for the BOARD basin. Collectively, these water budgets show the range of conditions simulated by the five inset models in response to the steady-state recharge, boundary conditions, and pumping conditions derived from the 2001-5 stress period of the parent LMB model.

Certain budget terms from the inset models are directly compared to the corresponding terms from the parent LMB model in table 9. The comparison shows good agreement between the LMB and inset model simulated values. For example, the values for net downward flow from the glacial deposits to bedrock deposits are quite similar. One difference between the LMB and inset models is that the LMB model was run in transient, rather than steady-state mode and, therefore, includes storage transfers as sources and sinks of groundwater.

It is worth noting that the basin-scale budgets cannot reveal differences between the parent and child models at the local scale where, for example, wells interact with surface water. The finer grid spacing of the inset models is expected to allow a more realistic simulation of groundwater/surface-water interactions than the parent LMB model (Feinstein and others, 2016) and, by extension, a more realistic simulation of times of travel to shallow wells under the influence of surface water.

\section{Model Limitations}

The limitations of a groundwater flow model are best considered in relation to the objectives of the modeling project. The inset models are intended as tools for simulating groundwater age at shallow wells in support of statistical modeling to quantify the strength of predictor variables in explaining age results. From this vantage point, four limitations are considered to be the most important—glacial layering, lateral grid spacing, preferential flow, and no recalibration.

1. Glacial layering.-The algorithm for discretizing the glacial layer was inherited from the parent LMB model. It depends on "hanging" the layer bottoms down from the land surface. Where the depth to bedrock (that is, glacial thickness from land surface) is less than $100 \mathrm{ft}$, the thicknesses of model layers 2 and 3 are considered pinched and set to $0.2 \mathrm{ft}$. These layers, which are assigned the aquifer properties of the overlying layers, have negligible effect on the head and flow results. Where the depth to bedrock is less than $300 \mathrm{ft}$, model layer 3 is assigned a thickness of $0.2 \mathrm{ft}$ and has negligible effect on the results. In the basin cells of the KALA model, layers 2 and 3 are both pinched in 25 percent of the area, layer 3 alone is pinched in 66 percent of the area, and no glacial layers are pinched in 9 percent of the area; the percentages adding to 100 percent. The corresponding values are 12,35 , and 53 percent for the BOARD basin area; 18, 79, and 3 percent for the UPFOX basin area; 58, 42, less than 0.1 percent for the MANI basin area; and 91, 9, and 0 percent for the WHITEDAM basin area. These statistics indicate that the vertical gradient within the basin glacial deposits can at least potentially be simulated for most of the KALA, BOARD, and UPFOX models, but that the glacial deposits are simulated as a one-layer flow system in most of the MANI and WHITEDAM models. If the layering algorithm had been different, for example, equal division of the glacial thickness into three layers, then (depending on the depth to the water table) there would have been more potential to resolve the vertical gradients within the glacial layers, especially in the MANI and WHITEDAM models. This capability could in principle have improved the precision of the simulation of flow conditions and, by extension, age estimates around partially penetrating sinks such as glacial wells.

Another implication of the glacial layering scheme for the inset models involves the relation of the water table to the open interval of the pumped wells. If the water table is in layer 1 at a given cell location, then any well assigned to layer 1 fully penetrates the layer and automatically draws water from its entire saturated thickness. That is, for this application of MODFLOW, there is no distance between the open interval of the well and the water table. The same is true if the water table is in layer 2 (or 3) and the well is assigned to layer 2 (or 3). Only in the case when the glacial well is open to a cell below a water-table layer is there a distance between the water table and the open interval. The depth of the open interval then depends on the simulated elevation of the water table and the elevation of the top of the layer occupied by the well. This depth is potentially an important explanatory variable for the age of groundwater discharge. It is expected that, everything else being equal, the deeper the open interval with respect to the water table, the longer the time required for particles to flow from the water table vertically downward to the well interval. The results of these traveltime calculations are to some degree a function of the layering imposed on the model. With more unpinched glacial layers than the 1,2 , or 3 present (depending on location) in the inset models, it would be possible to simulate a greater range of partially penetrating conditions and, therefore, a greater range of depths of the open interval below the water table. To mitigate this limitation, nearly one-half the hypothetical wells discussed farther on are inserted 
Table 9. Comparison of budget components for target HUC8 basins—-Lake Michigan Basin versus inset models.

[HUC8, 8-digit hydrologic unit code; $\mathrm{ft}^{3} / \mathrm{s}$, cubic foot per second; LMB, Lake Michigan Basin; na, not applicable]

\begin{tabular}{|c|c|c|}
\hline Budget components - fluxes (ft $\left.\mathrm{ft}^{3} \mathrm{~s}\right)$ & LMB & KALA \\
\hline Recharge to basin & 1,410 & 1,456 \\
\hline Net inflow into basin from surrounding basins & 14 & 14 \\
\hline Net discharge to surface water in basin & 1,296 & 1,348 \\
\hline Net downward flow from glacial deposits to bedrock in basin & 40 & 48 \\
\hline Net discharge to Lake Michigan from basin & 0 & 0 \\
\hline Net storage gain & 1 & na \\
\hline Budget components - fluxes $\left(\mathrm{ft}^{3} / \mathrm{s}\right)$ & LMB & BOARD \\
\hline Recharge to basin & 1,063 & 1,067 \\
\hline Net inflow into basin from surrounding basins & 119 & 90 \\
\hline Net discharge to surface water in basin & 1,123 & 1,072 \\
\hline Net downward flow from glacial deposits to bedrock in basin & 52 & 53 \\
\hline Net discharge to Lake Michigan from basin & 3 & 25 \\
\hline Net storage gain & 4 & na \\
\hline Budget components - fluxes ( $\left.\mathrm{ft}^{3} / \mathrm{s}\right)$ & LMB & UPFOX \\
\hline Recharge to basin & 727 & 736 \\
\hline Net inflow into basin from surrounding basins & 10 & 9 \\
\hline Net discharge to surface water in basin & 650 & 666 \\
\hline Net downward flow from glacial deposits to bedrock in basin & 48 & 42 \\
\hline Net discharge to Lake Michigan from basin & 0 & 0 \\
\hline Net storage gain & 0 & na \\
\hline Budget components - fluxes $\left(\mathrm{ft}^{3} / \mathrm{s}\right)$ & LMB & MANI \\
\hline Recharge to basin & 384 & 394 \\
\hline Net inflow into basin from surrounding basins & 10 & -5 \\
\hline Net discharge to surface water in basin & 312 & 302 \\
\hline Net downward flow from glacial deposits to bedrock in basin & 82 & 82 \\
\hline Net discharge to Lake Michigan from basin & 2 & 3 \\
\hline Net storage gain & 4 & na \\
\hline Budget components - fluxes $\left(\mathrm{ft}^{3} / \mathrm{s}\right)$ & LMB & WHITEDAM \\
\hline Recharge to basin & 629 & 599 \\
\hline Net inflow into basin from surrounding basins & -17 & -31 \\
\hline Net discharge to surface water in basin & 417 & 490 \\
\hline Net downward flow from glacial deposits to bedrock in basin & 60 & 77 \\
\hline Net discharge to Lake Michigan from basin & 1 & 0 \\
\hline Net storage gain & 0 & na \\
\hline
\end{tabular}


into layers 2 or 3 of the inset models (the details of the algorithm are given in subsection titled "Seeded Glacial Wells") in order to increase the probability that they will be open below the water table and to ensure that the effect of partial penetration on groundwater discharge age can be evaluated as part of a prospective statistical modeling process.

2. Lateral grid spacing.--In terms of locating sinks, simulating groundwater/surface-water interactions, and predicting the age of shallow well discharge, the refinement of the inset models to a 500-ft row and column resolution is a great improvement over the parent LMB model's 5,000-ft resolution. However, there are some areas in the model where multiple existing glacial wells are collocated in a single model cell. In such cases, the drawdown patterns around the individual wells are not as well resolved as elsewhere.

3. Preferential flow.-Glacial deposits in the LMB study area tend to be more heterogeneous than bedrock units. The sequence of depositional and erosional glacial processes can produce large changes in hydraulic conductivity values over short horizontal and vertical distances (Feinstein and others, 2012). Alluvial deposition can further complicate the hydraulic conductivity pattern. For example, the unlithified sequence in the inset model areas can contain surficial or buried gravel-dominated channel deposits in outwash or modern alluvial settings that are continuous or local in spatial extent. It is very difficult to map the thin linear geometry of these coarse deposits because of the grid spacing and the spacing of available logs, but the coarse deposits can dominate the flow field by providing paths of preferential flow (Zheng and others, 2010). It is possible that the volume of preferential flow paths is underestimated in some areas of the inset models, and, therefore, in such areas the simulated groundwater age of well discharge could be biased high.

4. No recalibration.- The inputs to the inset models were not subject to a separate calibration process using either the types of calibration targets assembled for the LMB model or a new set of targets. Many of the boundary conditions and aquifer properties input to the inset models are inherited from the LMB model. To the extent that the calibration of the LMB unconfined model (Feinstein and others, 2010, sections 5 and 7.1) serves to tie the model inputs to observations, the inset models benefit from the original history-matching process. Some of the updated input values for the inset models changed only slightly from the LMB model inputs (for example, the elevation of the top bedrock surface, glacial hydraulic conductivity distribution) and probably had a limited effect on output. However, other modifications have the potential to yield larger differences in output in local areas, especially with respect to groundwater/surfacewater interactions. For example, the refinement of the grid spacing around sinks and the insertion of a dense network of routed SFR2 cells to replace the original sparser network of RIV cells could have a local effect on head and flux output. Certain results might be especially sensitive to a re-calibration process. It is possible, for instance, that a re-calibration of the inset models would have reduced the number of cells where the simulated water table is above the land surface. (The white areas in fig. 21 correspond to "flooded" cells with simulated groundwater head above the average assigned land surface equal to $8,4,8,9$, and 25 percent of the inland areas of the KALA, BOARD, UPFOX, MANI and WHITEDAM model domains, respectively. The median simulated height of flooding was equal to about 3, 5, 4, 4 , and $11 \mathrm{ft}$ in the inland areas of the KALA, BOARD, UPFOX, MANI and WHITEDAM model domains, respectively.) Many of these flooded cells occur in riparian zones along steam channels and reflect the simplification of the models by omitting small seasonably variable wetland features that occupy terraces adjacent to streams (Hunt and others, 2008). This sort of "structural error" is not readily eliminated through history matching (Hunt and others, 2007, Doherty and Welter, 2010). In some areas, however, it is possible that a recalibration of the inset models would have reduced flooding in upland areas, where it is probably spurious unless a large amount of topographic relief within the cell area is a factor. More generally, an updating of the hydraulic conductivity or recharge fields could have resulted in a better fit to the database of calibration head targets assembled for the parent LMB model or to an extended version of the calibration target database. However, it is important to emphasize that the aim of this study was not to produce models that are suitable for addressing management questions at particular locations. Rather, the goal was to provide a method to distill the physical processes simulated in the MODFLOW model into the correlation and sensitivity structures of a statistical model to assess groundwater age in different geologic environments. It is the correlation and sensitivity structures that are most important, not the specific results for specific locations. These structures are expected to be largely captured by the models even if the simulated head and flow conditions are not optimal with respect to available calibration targets. For this reason, the re-calibration of the inset models against available targets was not deemed a necessary step in the overall metamodeling project.

In addition to the limitations discussed here and specific to the development of the inset models, the inset models also inherit limitations present in the parent LMB model. The inherited limitations include gaps in available hydrogeologic data such as elevations of deep bedrock layers and unrepresented processes such as pumping from domestic wells. For more discussion of these background limitations, see Feinstein and others, 2010. 


\section{Comparison of Inputs and Outputs Among Inset Models}

In preparation for the application of the inset models to the statistical modeling of the age distribution of groundwater discharge to glacial wells, it is useful to compare and contrast the inputs and outputs of the inset models. More specifically, it is useful to explore the range of conditions in the glacial aquifer system captured by the inset models. This range is conditioned, on the one hand, by the geographic restriction of the inset models to a domain in one part (the upper Midwest) of the U.S. glacial aquifer system and, on the other hand, by the variety of glacial settings encountered within this Lake Michigan-centered domain.

Statistical modeling connects the behavior of potential predictors (that is, selected inputs and outputs of the processbased model) to outcomes of interest (the outputs of concern from the process-based model). Before any statistical models are formally constructed, it is informative to evaluate the behavior of potential predictors of groundwater age by evaluating their expected values and their distributions around the expected value over a specified domain. To perform this exploratory analysis, the expected value for each of the selected inputs and outputs of the inset models is equated to its median value. The distribution of values is represented by the spread between the 5 th percentile and the 95 th percentile of the distribution, incorporating 90 percent of the ranked values. The graphs and boxplots in figure 24 show the distributions for the conditions pertaining, not to the whole domain, but to the HUC8 basins only within each inset model. Each graph or boxplot contains the distribution statistics for a single variable for all five inset models (fig. 2). The input and output variables selected were judged to have the potential to be predictors of the simulated groundwater ages that are discussed in the next section.

In figure 24, graphs $A-D$ and $J$ show inputs to the inset models. Graphs $E-I$ also show inputs but depend on the simulated position of the water table to yield saturated thickness terms. Graphs $K-R$ show model outputs associated with simulated water levels and fluxes. Items $O-R$ are associated with surface-water features simulated as perennial under steadystate conditions (that is SFR cells representing stream reaches with active base flow and DRN cells representing water bodies that are actively discharging groundwater).

In examining the 18 boxplots in figure 24, it is evident that some degree of variation among inset models is present for all the selected inputs and outputs. The distributions showing the most relative variability include the number of glacial wells inside the basins (fig. 24B), the saturated glacial thickness (fig. 24E), the simulated depth to the water table (fig. $24 K$ ), and the contribution of simulated upward flow from the bedrock (fig. 24N). Also showing appreciable variability among basins are the distributions for recharge (fig. 24D), saturated bedrock thickness (fig. 24F), composite saturated glacial horizontal hydraulic conductivity (fig. 24G), saturated glacial transmissivity (fig. $24 H$ ), and the stream density (fig. 24O). It is notable that the part of the basin area with upward hydraulic gradient from the top of bedrock (fig. 24M) varies between 16 percent for WHITEDAM and 42 percent for BOARD. It is possible that the groundwater age of shallow well discharge is sensitive to the amount of water captured from the bedrock if groundwater passing through the bedrock tends on average to move more slowly and over longer pathlines than circulation restricted to the glacial deposits. This particular hypothesis is tested in the section "Age Metrics of Groundwater Discharge to Wells." The overall point of this graphing exercise was to show that the inset model domains, although they are near Lake Michigan, represent different regimes with respect to glacial geology and hydrogeology. What relation these regimes have to the simulated distributions of groundwater age in well discharge can be partly explored using the inset models themselves, but ultimately the relation will be tested through the distilling by statistical means of the correlation structures binding predictor distributions to appropriate groundwater age metrics. In general, the behavior shown in these graphs is potentially useful in the context of interpreting prospective metamodeling results (for example, explaining why certain predictors are most important as explanatory variables).

The candidate predictors to be considered in the prospective metamodeling will not only draw from the inputs and outputs featured in figure 24, but will also reflect characteristics of the glacial wells that could influence the age of discharge such as depth of open interval below the water table. The next section includes discussion of some of these characteristics.

\section{Application of Inset Models to Calculate Age Distribution in Groundwater Discharge to Glacial Wells}

One of the goals of NAWQA is to map the intrinsic susceptibility of groundwater across the glacial aquifer of the conterminous United States to contamination. Eberts and others (2013) define intrinsic susceptibility as "a measure of the ease with which a contaminant in water can enter and move through an aquifer. It is a characteristic of the aquifer and overlying material, and it is independent of the contaminant characteristics or source." An important indicator of intrinsic susceptibility to contamination is groundwater age, with younger ages indicating either recent recharge or rapid movement and, therefore, potential susceptibility to contamination from anthropogenic activities at the land surface, such as leaching of nitrates from fertilizer. Older water is typically more susceptible to mobilization of natural contaminants because of geochemical processes, such as mobilization of arsenic in reduced water (Ebert and others, 2013). The expected age of shallow well discharge is thus a possible 

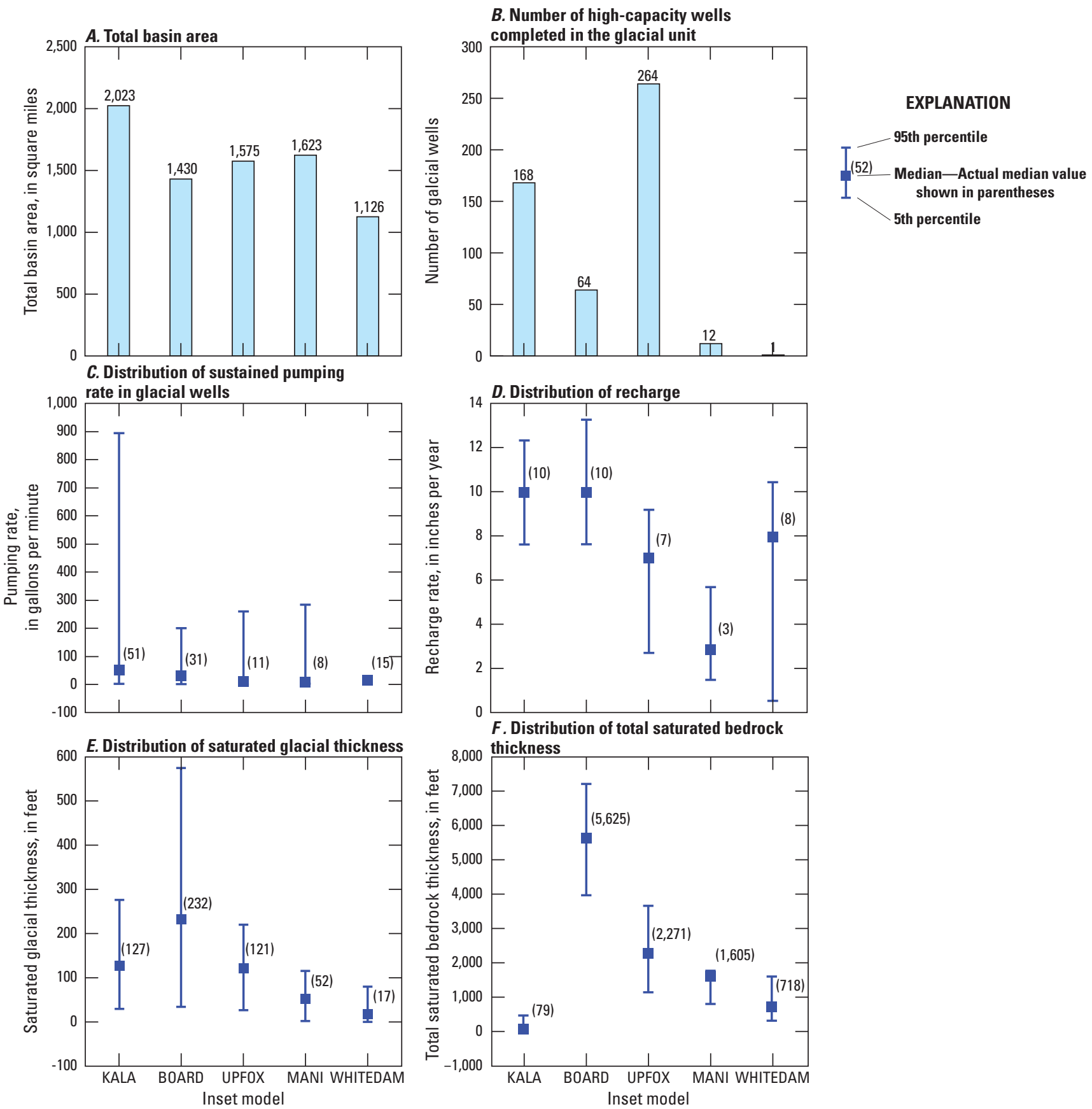

Figure 24. Comparison of values or statistical distributions of key inputs and outputs across target 8-digit hydrologic unit code (HUC8) basins. Statistical distributions defined by median, 5th percentile, and 95th percentile of values in boxplots. The median value is labelled on plots; the 5th and 95th percentiles are indicted by the lower and upper extents of the bars. $A$, total basin area; $B$, number of high-capacity wells completed in the glacial unit; $C$, distribution of sustained pumping rate in glacial wells; $D$, distribution of recharge; $E$, distribution of saturated glacial thickness; $F$, distribution of total saturated bedrock thickness; $G$, distribution of composite saturated glacial horizontal hydraulic conductivity; $H$, distribution of saturated glacial transmissivity; $I$, distribution of the percent contribution of saturated glacial transmissivity to total saturated transmissivity; $J$, distribution of vertical anisotropy-ratio of horizontal to vertical hydraulic conductivity - in glacial deposits (value in each model layer weighted by saturated thickness); $K$, distribution of simulated depth to water table; $L$, distribution of simulated vertical gradient between water table and top of bedrock aquifer; $M$, distribution of simulated upward hydraulic gradient from top bedrock aquifer to water table; $N$, percentage of inflow to glacial deposits simulated as upward bedrock flow; 0 , distribution of minimum distance from center of cell with glacial well to center of cell with active surfacewater body; $P$, percentage of first-order streams simulated as dry; $Q$, percentage of second-order and higher streams simulated as dry; and $R$, percentage of basin area with surface-water bodies simulated in connection with groundwater. 

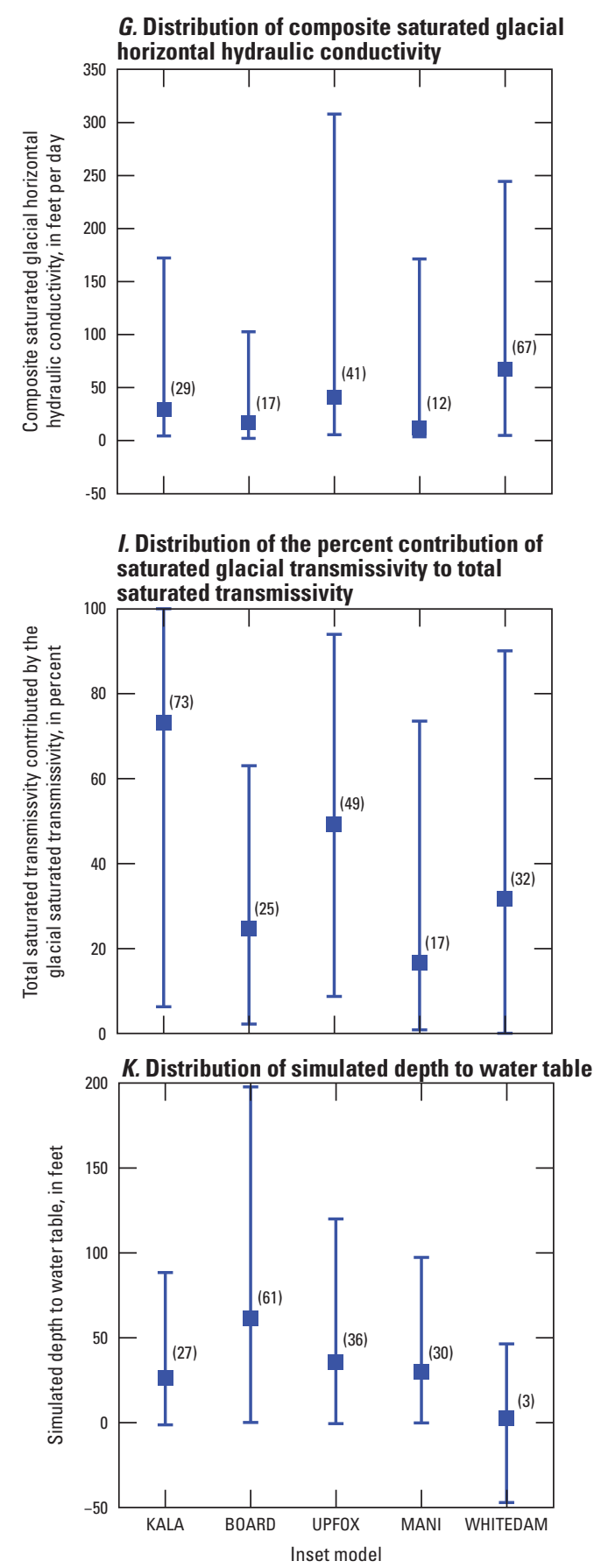

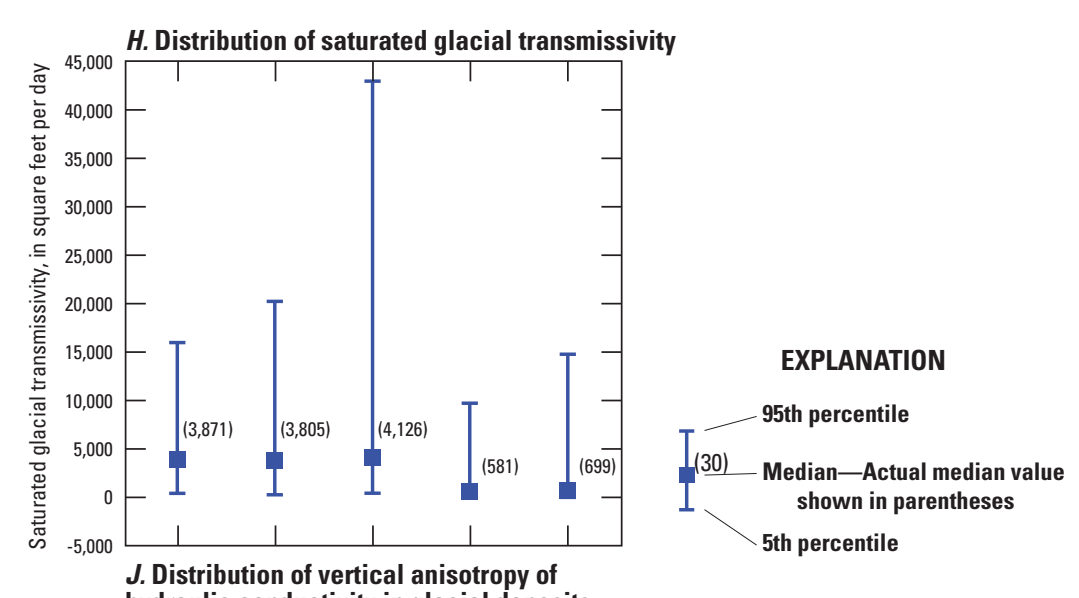

J. Distribution of vertical anisotropy of hydraulic conductivity in glacial deposits (value in each layer weighted by
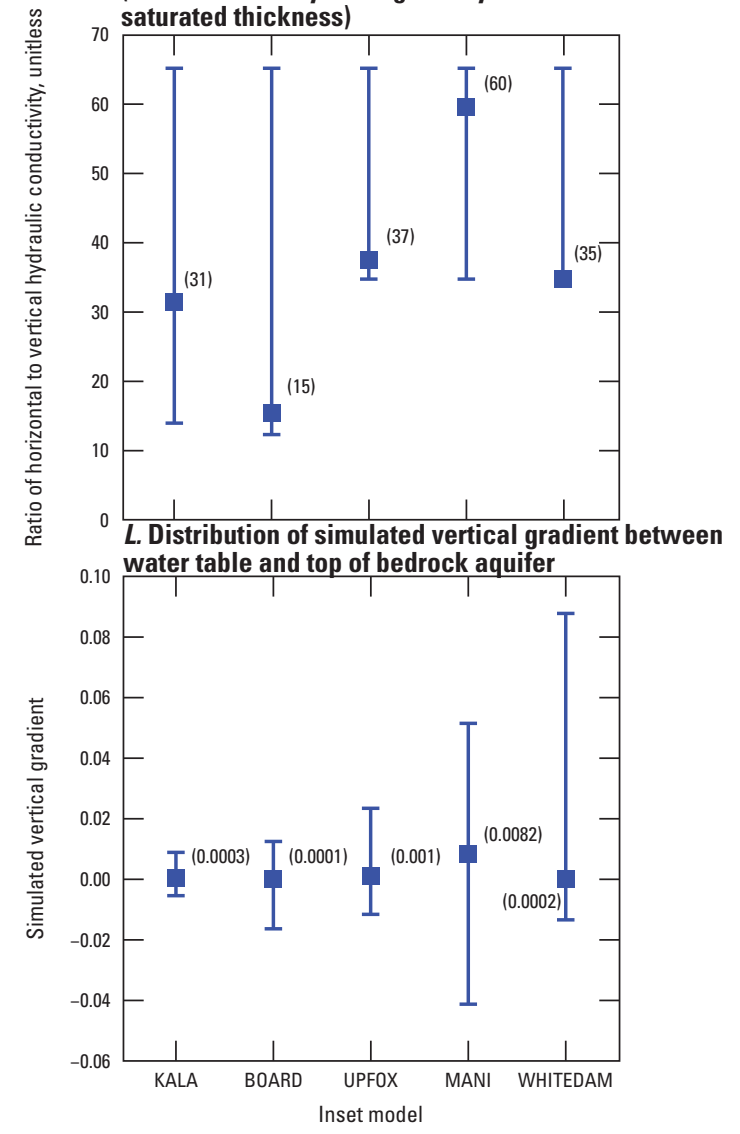

Figure 24. Comparison of values or statistical distributions of key inputs and outputs across target 8-digit hydrologic unit code (HUC8) basins. Statistical distributions defined by median, 5th percentile, and 95th percentile of values in boxplots. The median value is labelled on plots; the 5th and 95th percentiles are indicted by the lower and upper extents of the bars. $A$, total basin area; $B$, number of high-capacity wells completed in the glacial unit; $C$, distribution of sustained pumping rate in glacial wells; $D$, distribution of recharge; $E$, distribution of saturated glacial thickness; $F$, distribution of total saturated bedrock thickness; $G$, distribution of composite saturated glacial horizontal hydraulic conductivity; $H$, distribution of saturated glacial transmissivity; $I$, distribution of the percent contribution of saturated glacial transmissivity to total saturated transmissivity; $J$, distribution of vertical anisotropy — ratio of horizontal to vertical hydraulic conductivity - in glacial deposits (value in each model layer weighted by saturated thickness); $K$, distribution of simulated depth to water table; $L$, distribution of simulated vertical gradient between water table and top of bedrock aquifer; $M$, distribution of simulated upward hydraulic gradient from top bedrock aquifer to water table; $N$, percentage of inflow to glacial deposits simulated as upward bedrock flow; 0 , distribution of minimum distance from center of cell with glacial well to center of cell with active surfacewater body; $P$, percentage of first-order streams simulated as dry; $Q$, percentage of second-order and higher streams simulated as dry; and $R$, percentage of basin area with surface-water bodies simulated in connection with groundwater.-Continued 


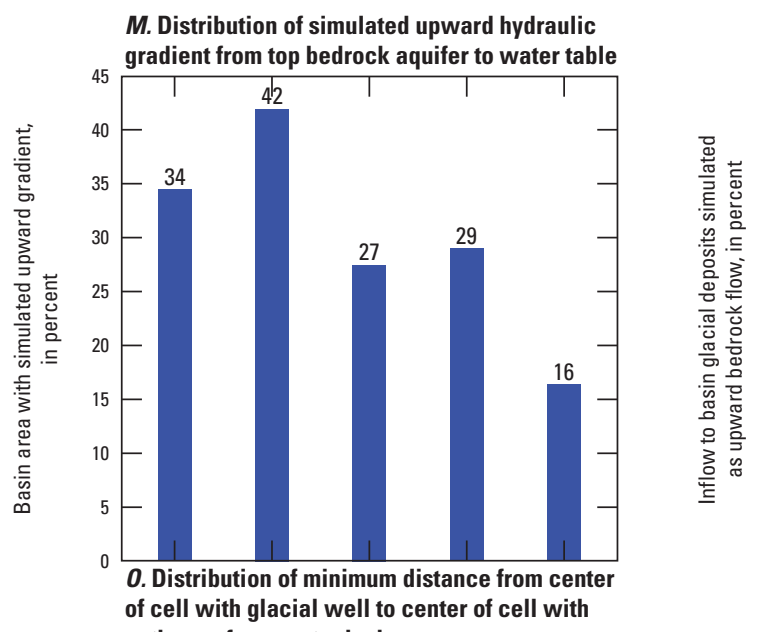

N. Percentage of inflow to glacial deposits simulated as upward bedrock flow
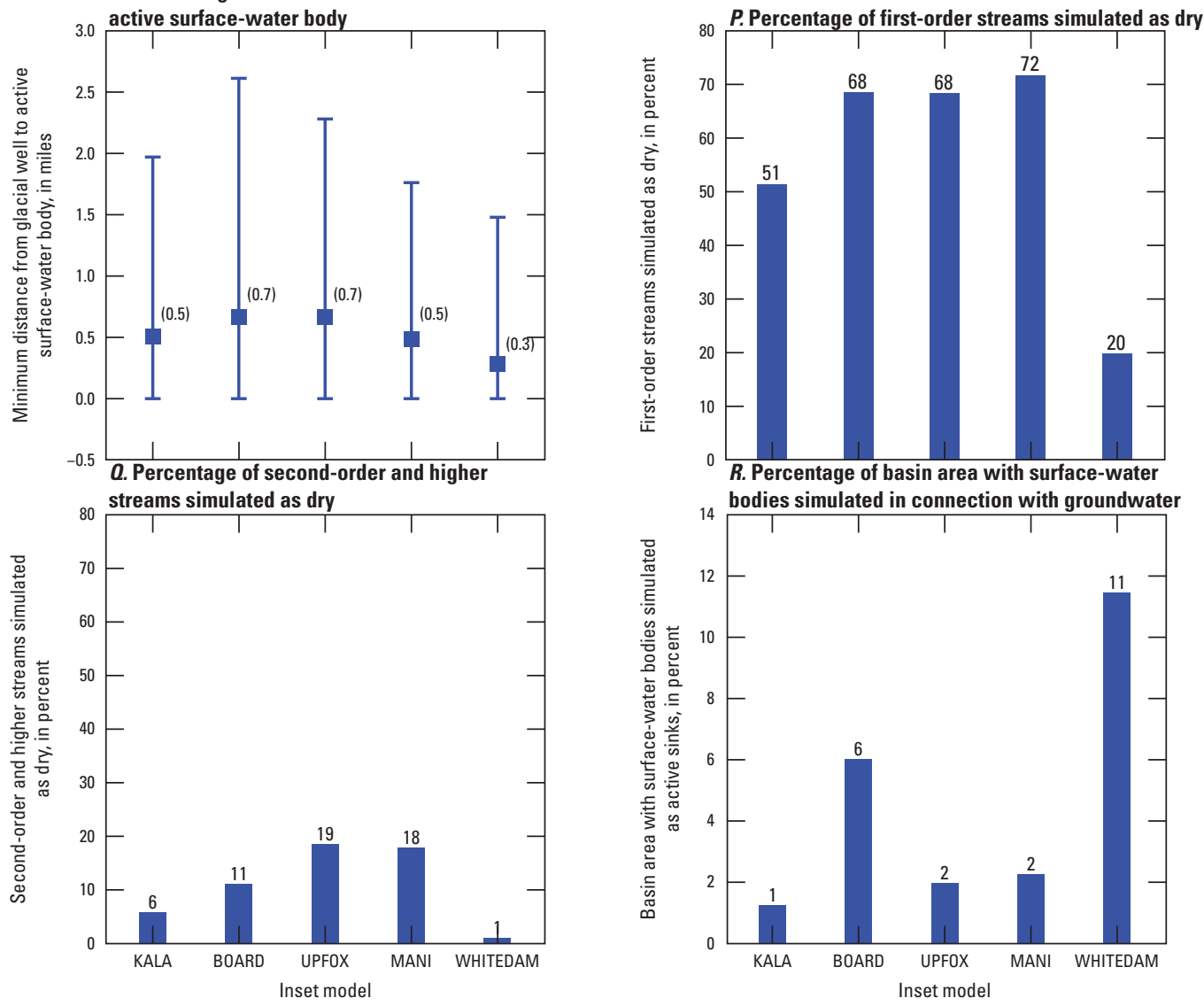

Figure 24. Comparison of values or statistical distributions of key inputs and outputs across target 8-digit hydrologic unit code (HUC8) basins. Statistical distributions defined by median, 5th percentile, and 95th percentile of values in boxplots. The median value is labelled on plots; the 5th and 95th percentiles are indicted by the lower and upper extents of the bars. $A$, total basin area; $B$, number of high-capacity wells completed in the glacial unit; $C$, distribution of sustained pumping rate in glacial wells; $D$, distribution of recharge; $E$, distribution of saturated glacial thickness; $F$, distribution of total saturated bedrock thickness; $G$, distribution of composite saturated glacial horizontal hydraulic conductivity; $H$, distribution of saturated glacial transmissivity; $I$, distribution of the percent contribution of saturated glacial transmissivity to total saturated transmissivity; $J$, distribution of vertical anisotropy-ratio of horizontal to vertical hydraulic conductivity —in glacial deposits (value in each model layer weighted by saturated thickness); $K$, distribution of simulated depth to water table; $L$, distribution of simulated vertical gradient between water table and top of bedrock aquifer; $M$, distribution of simulated upward hydraulic gradient from top bedrock aquifer to water table; $N$, percentage of inflow to glacial deposits simulated as upward bedrock flow; 0 , distribution of minimum distance from center of cell with glacial well to center of cell with active surfacewater body; $P$, percentage of first-order streams simulated as dry; $Q$, percentage of second-order and higher streams simulated as dry; and $R$, percentage of basin area with surface-water bodies simulated in connection with groundwater.-Continued 
indicator of the types of contamination to which an area of the glacial aquifer system is most susceptible.

The central objective guiding the construction of the inset models was their application to the problem of simulating and predicting groundwater age in glacial well discharge. To this end the flow to the existing glacial wells can be analyzed (by means of particle tracking) to determine the relation between model properties and the distribution of the simulated age of groundwater discharging to the wells. However, in order to more fully exploit the inset models, the base simulations with the existing glacial wells were supplemented by a series of simulations with hypothetical "seeded" wells. The analysis of the flow to the seeded wells greatly increased the number of instances available for exploring the relation between model properties and groundwater age.

\section{Existing Glacial Wells}

Data on the existing glacial wells in the inset models were obtained from the databases of state water-use records assembled for the parent LMB model. The existing wells are represented by the MODFLOW Multi-Node Well package. The KALA inset model contained 172 high-capacity glacial wells within the target HUC8 basin (33 are multi-layer) with expected total well discharge equal to 57.8 million gallons per day (Mgal/d). The BOARD HUC8 basin contained 64 glacial wells (20 multi-layer) pumping $5.2 \mathrm{Mgal} / \mathrm{d}$; the UPFOX HUC8 basin, 264 glacial wells (41 multi-layer) pumping $25.4 \mathrm{Mgal} / \mathrm{d}$; the MANI HUC8 basin, 12 glacial wells (3 multi-layer) pumping $1.3 \mathrm{Mgal} / \mathrm{d}$; and the WHITEDAM HUC8 basin, 1 glacial well (0 multi-layer) pumping $0.02 \mathrm{Mgal} / \mathrm{d}$. The total number of glacial wells entered for the inset model HUC8 basins is 513. The model layer or layers intersected by the open interval of each well and assigned the MNW2 package were derived from the parent LMB model; the elevation changes in the tops and bottoms of model layers in the inset models were small enough that little error is introduced by using the parent LMB model layer assignments.

Most of the existing glacial wells in the inset basins were used in the groundwater age analysis. However, some were excluded from the analysis either because there were multiple MNW2 wells in a single cell (in that case all these wells are excluded from the analysis given the difficulty in determining the groundwater age distribution in any of the wells) or because the well was simulated as dry. The final tally for existing glacial wells subject to analysis is 398 (table 10). About one-third of these wells penetrate only layer 1; the

Table 10. Number and distribution by layer of existing and seeded glacial wells for target HUC8 basins within inset models.

[Only glacial wells used for age calculations included. Average percent in each layer calculated by summing the product of the number of glacial wells by basin with the percent in layer, then dividing by sum of existing or seeded glacial wells. HUC8, 8-digit hydrologic unit code; MNW2, multi-node well; WEL, well]

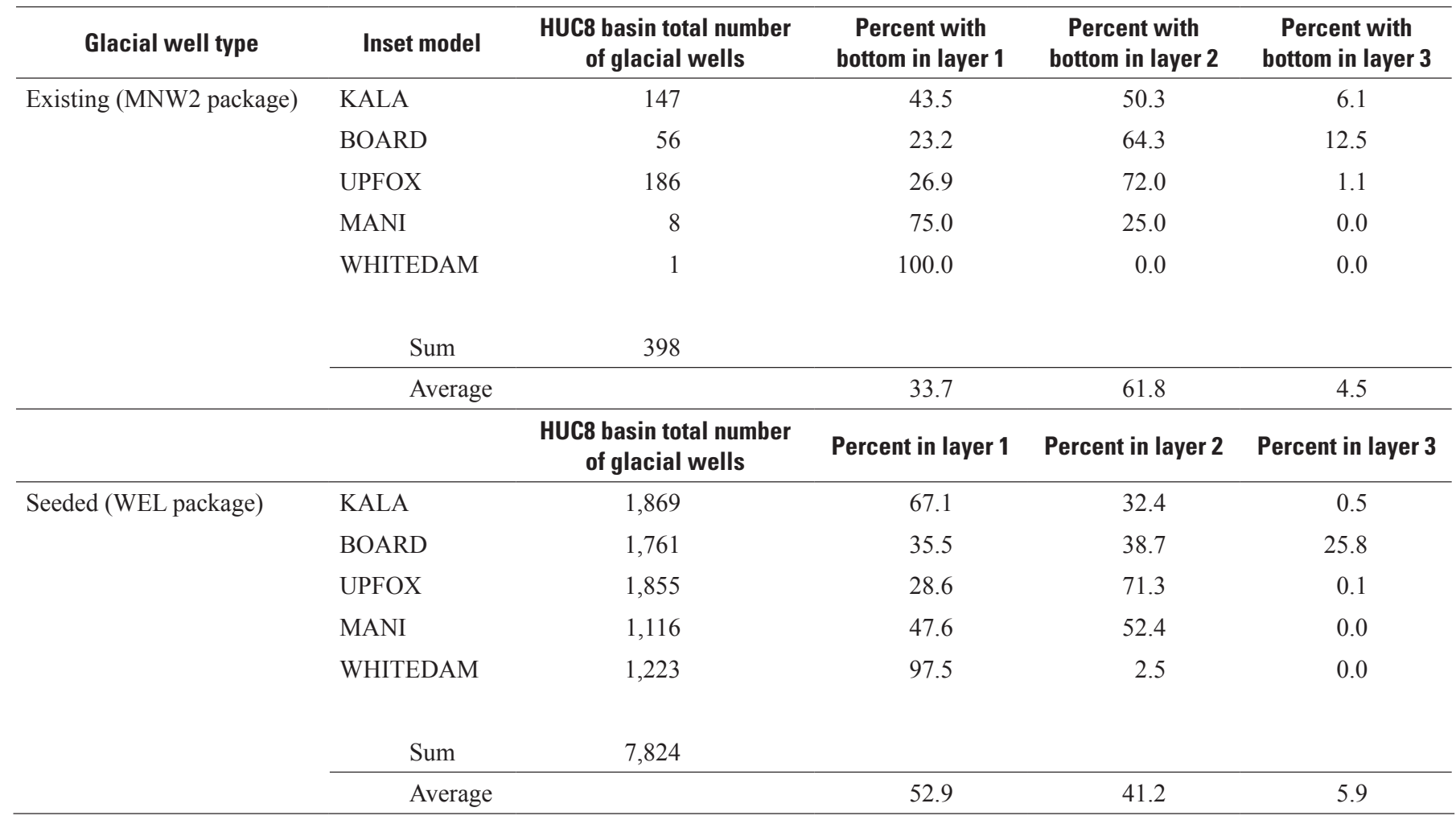


remaining two-thirds penetrate deeper into the glacial system (table 10). The distribution of the wells, by layer, is important because wells in layers 2 and 3 can be open to depths below the water table, a condition which is potentially an important control on the age of the well discharge. The spatial distributions of recorded glacial well pumping rates are shown in figures $3 A-E$.

\section{Seeded Glacial Wells}

The seeded glacial wells in the inset models are represented by the MODFLOW WEL package. They are limited to one layer and to the target basin area. The methods for selecting well location, layer designation, and pumping rate are detailed in the following paragraphs.

The row/column locations in each target basin for each inset model were arranged in random order. A cell was chosen in sequence and selected if it did not contain an existing well input through the MNW2 package. Locations containing surface-water features (using the SFR2 or DRN package) were allowed; they represent 6.8 percent of the selected seeded well locations across the target basins.

The layer assigned a seeded well was a function of saturated glacial transmissivity in the base model. The seeded well was assigned to model layer 3 at the selected row/column location if it contained at least 20 percent of the total saturated glacial transmissivity. Failing this, the well was assigned to layer 2 if it contained at least 20 percent of the total saturated glacial transmissivity. Otherwise, the well was assigned to layer 1 . This procedure across the five target basins resulted in about 53 percent of the seeded wells assigned to layer 1, about 41 percent to layer 2, and 6 percent to layer 3 (table 10).

The pumping rate assigned to a seeded glacial well was obtained from a distribution that approximates the range of pumping from existing high-capacity wells in the target basins. For the KALA basin, the range of existing rates for the high-capacity wells was between about 1.5 and $1,500 \mathrm{gal} / \mathrm{min}$, for the BOARD basin between about 1 and $400 \mathrm{gal} / \mathrm{min}$, and for the UPFOX basin between about 0.2 and $600 \mathrm{gal} / \mathrm{min}$ (fig. 25). It is noteworthy that even though the existing wells are categorized as high-capacity wells, most of their estimated average pumping rates recorded in the LMB model database are much lower than the $70 \mathrm{gal} / \mathrm{min}$ threshold, possibly because they are pumped only part of the year. A semi-log trend line was fitted to the ranked distribution of pumping from the KALA, BOARD, and UPFOX basins (fig. 25). Points along this best-fit line was sampled randomly for each of the selected seeded well locations. The ensemble of seeded well pumping rates, therefore, is statistically similar to the ensemble of high-capacity pumping rates. The ensemble of high-capacity wells in the MANI and WHITEDAM basins was too small to perform the semi-log fit. The pumping rates for these basins were randomly drawn from a representative semi-log distribution with rates varying between 2 and $200 \mathrm{gal} / \mathrm{min}$.
The selection process was used to generate 2,000 wells for each target basin (table 10). However, as a result of interference between wells, it was not practical to create a single inset simulation with all the seeded wells active. Instead sets of as many as 25 seeded wells input through the WEL package were added to the existing high-capacity wells input through the MNW2 to generate new simulations. All told, each inset model was subjected to 80 simulations, each of which contained all the existing wells and a maximum of 25 seeded glacial wells selected randomly from the 2,000 seeded well locations identified for testing for each inset model. Further filtering was performed to avoid seeded wells going dry. Locations were assigned zero discharge in the WEL package if the total saturated glacial transmissivity for the three glacial layers resolved by the base model (that is, using existing wells) amounted to less than $500 \mathrm{ft}^{2} / \mathrm{d}$. This restriction effectively eliminated about 21 percent of the candidate seeded wells. The MANI and WHITEDAM basins suffered the highest rates of removal because of extensive areas of fine-textured and (or) thin glacial deposits. The candidate seeded well locations that met the transmissivity restriction and were subject to the particle tracking analysis are shown for an example simulation for each inset model in figures $26 A-E$. This figure also delineates the existing glacial wells and the simulated active surface-water network consisting of flowing SFR and discharging DRN cells, by layer, for each inset model. The full set of seeded well locations subject to particle tracking across all inset model simulations is shown in figures $27 A-E$.

An "assigned" pumping rate was input to the existing and seeded wells that can be different from the "sustained" pumping rate yielded by the solution. In the case of the existing wells modeled using the MNW2 package (Konikow and others, 2009), the assigned rate, based on estimates in well records, is reduced if certain seepage face conditions hold around the well. For the baseline simulation for the inset models, the percent losses of assigned discharge to existing high-capacity glacial wells are 10.7 percent for KALA, 4.4 percent for BOARD, 9.0 percent for UPFOX, 6.9 percent for MANI, and 39.5 percent for WHITEDAM (where the glacial thickness is generally very thin); collectively, the overall loss rate is 9.4 percent of assigned discharge. In the case of the seeded wells modeled using the WEL package and the Newton-Raphson Solver (Niswonger and others, 2011), the assigned rate is reduced if the saturated thickness of the layer occupied by the well falls below a threshold (in this study always set to 20 percent of the total layer thickness). Across all the simulations for each inset model, the percent loss of assigned discharge to seeded wells is 8.6 percent for KALA, 2.3 percent for BOARD, 2.0 percent for UPFOX, 4.1 percent for MANI, and 7.5 percent for WHITEDAM; collectively the overall loss rate is 6.0 percent of assigned discharge. It is possible that the seeded wells on average sustain more of their assigned pumping rate than do the existing wells because of the $500-\mathrm{ft}^{2} / \mathrm{d}$ glacial saturated transmissivity minimum used to screen seeded well locations. In any event, the predictors that involve the pumping rate at a glacial well (existing or 

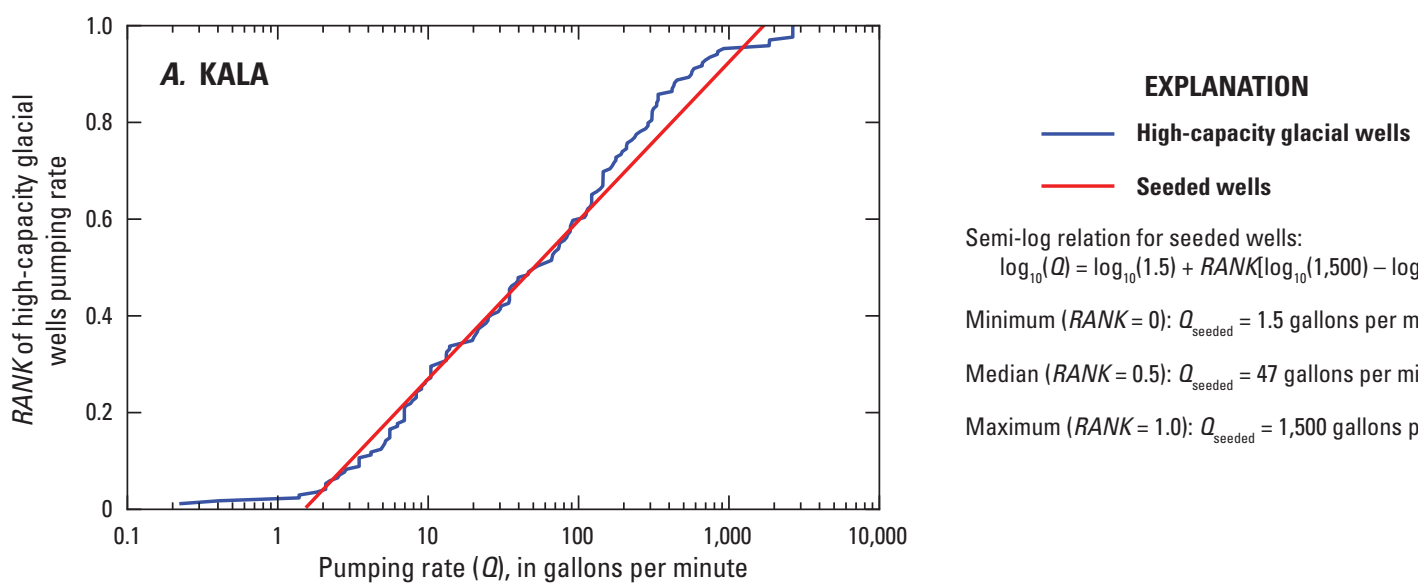

Semi-log relation for seeded wells:

$\log _{10}(Q)=\log _{10}(1.5)+R A N K\left[\log _{10}(1,500)-\log _{10}(1.5)\right]$

Minimum $(R A N K=0): Q_{\text {seeded }}=1.5$ gallons per minute

Median $(R A N K=0.5): Q_{\text {seeded }}=47$ gallons per minute

Maximum $(R A N K=1.0): Q_{\text {seeded }}=1,500$ gallons per minute

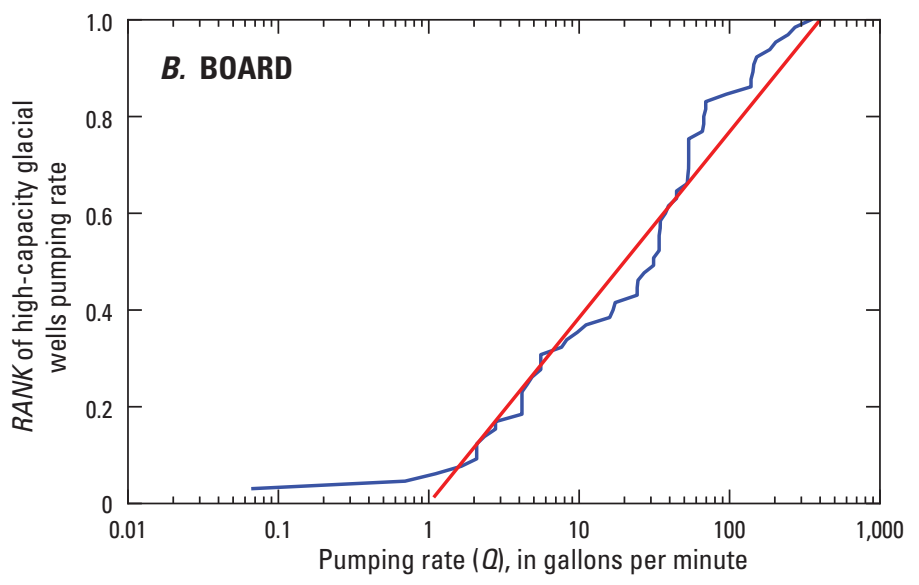

\section{EXPLANATION}

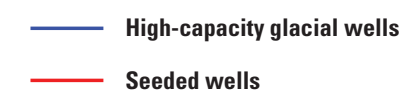

Semi-log relation for seeded wells:

$\log _{10}(Q)=\log _{10}(1.0)+R A N K\left[\log _{10}(400)-\log _{10}(1.0)\right]$

Minimum $(R A N K=0): Q_{\text {seeded }}=1.0$ gallons per minute

Median $(R A N K=0.5): Q_{\text {seeded }}=20$ gallons per minute

Maximum $(R A N K=1.0): Q_{\text {seeded }}=400$ gallons per minute

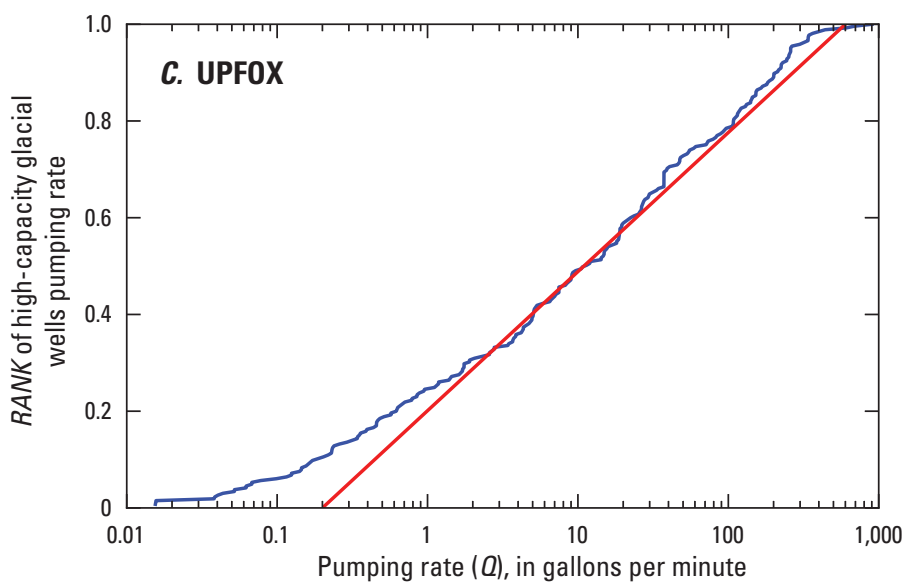

\section{EXPLANATION}

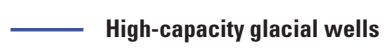

Seeded wells

Semi-log relation for seeded wells:

$\log _{10}(Q)=\log _{10}(0.2)+R A N K\left[\log _{10}(600)-\log _{10}(0.2)\right]$

Minimum $(R A N K=0): Q_{\text {seeded }}=0.2$ gallons per minute

Median $(R A N K=0.5): Q_{\text {seeded }}=11$ gallons per minute

Maximum $(R A N K=1.0): Q_{\text {seeded }}=600$ gallons per minute

Note: There are too few high-capacity glacial wells in the MANI and WHITEDAM
basins to construct a semi-log relation for seeded wells. The seeded well pumping
rate distribution is imposed in these two basins using the following semi-log relation:
\[ \begin{array}{l}\log _{10}(Q)=\log _{10}(2)+R A N K\left(\log _{10}(200)-\log _{10}(2)\right] \\ \text { Minimum }(R A N K=0): Q_{\text {seded }}=2 \text { gallons per minute } \\ \text { Median (RANK=0.5): } Q_{\text {seded }}=20 \text { gallons per minute } \\ \text { Maximum (RANK }=1.0): Q_{\text {seded }}=200 \text { gallons per minute }\end{array} \]

Figure 25. Pumping rates for existing high-capacity glacial wells and semi-log trend lines fit to the ranked distribution of pumping for $A$, KALA; $B, \mathrm{BOARD} ; C$, UPFOX; $D$, MANI; and $E$, WHITEDAM basins. (RANK refers to the fractional place order of the existing pumping rate arranged by size.) 


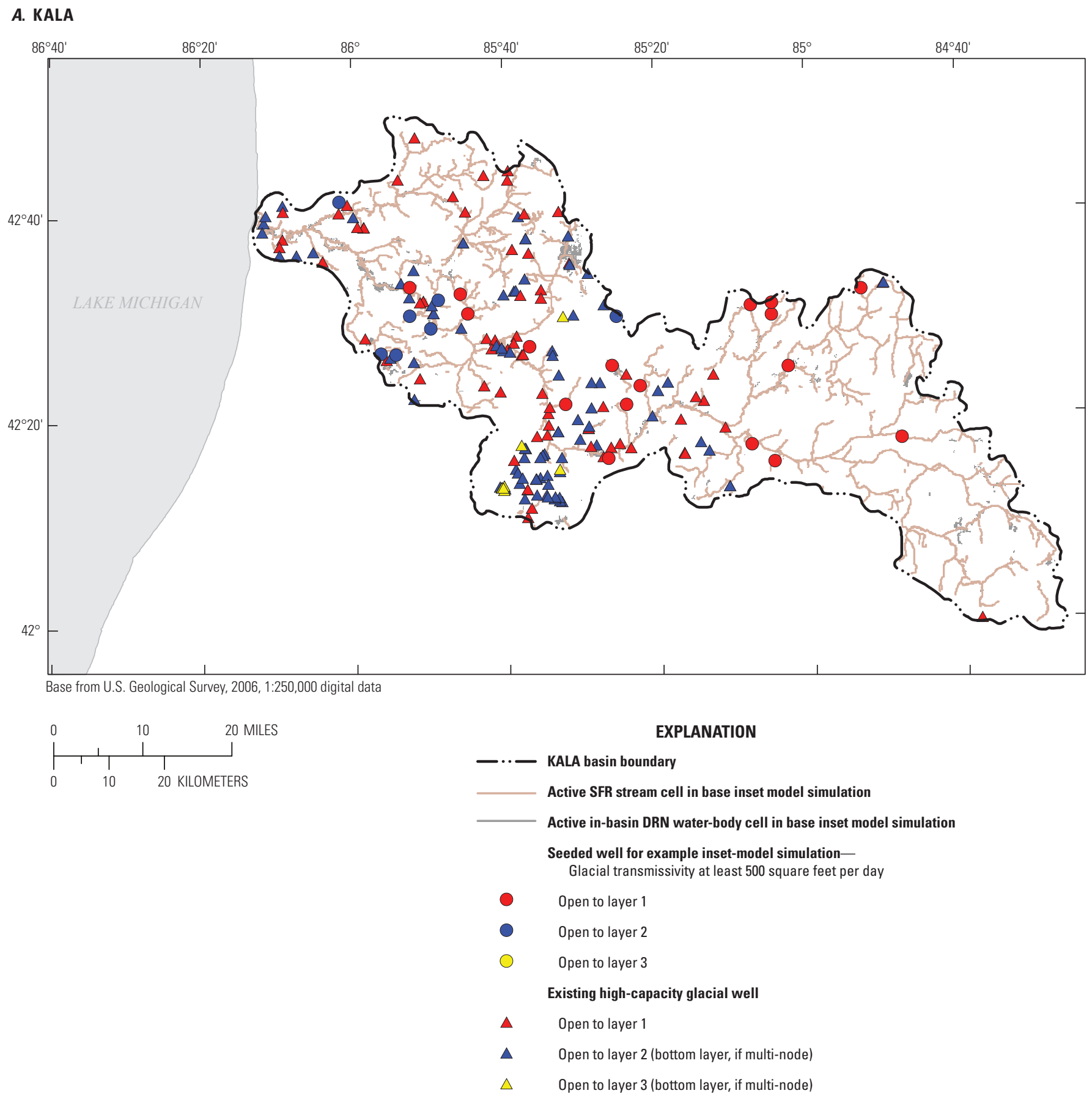

Figure 26. Maps for each inset model showing the locations of seeded wells by layer for an example simulation, along with the locations of existing glacial wells by layer, active water body cells, and the active stream cells for $A, \mathrm{KALA} ; B, \mathrm{BOARD;} C, \mathrm{UPFOX}$; $D, \mathrm{MANI}$; and E, WHITEDAM. (SFR, streamflow routing package; DRN, drain package.) 
B. BOARD

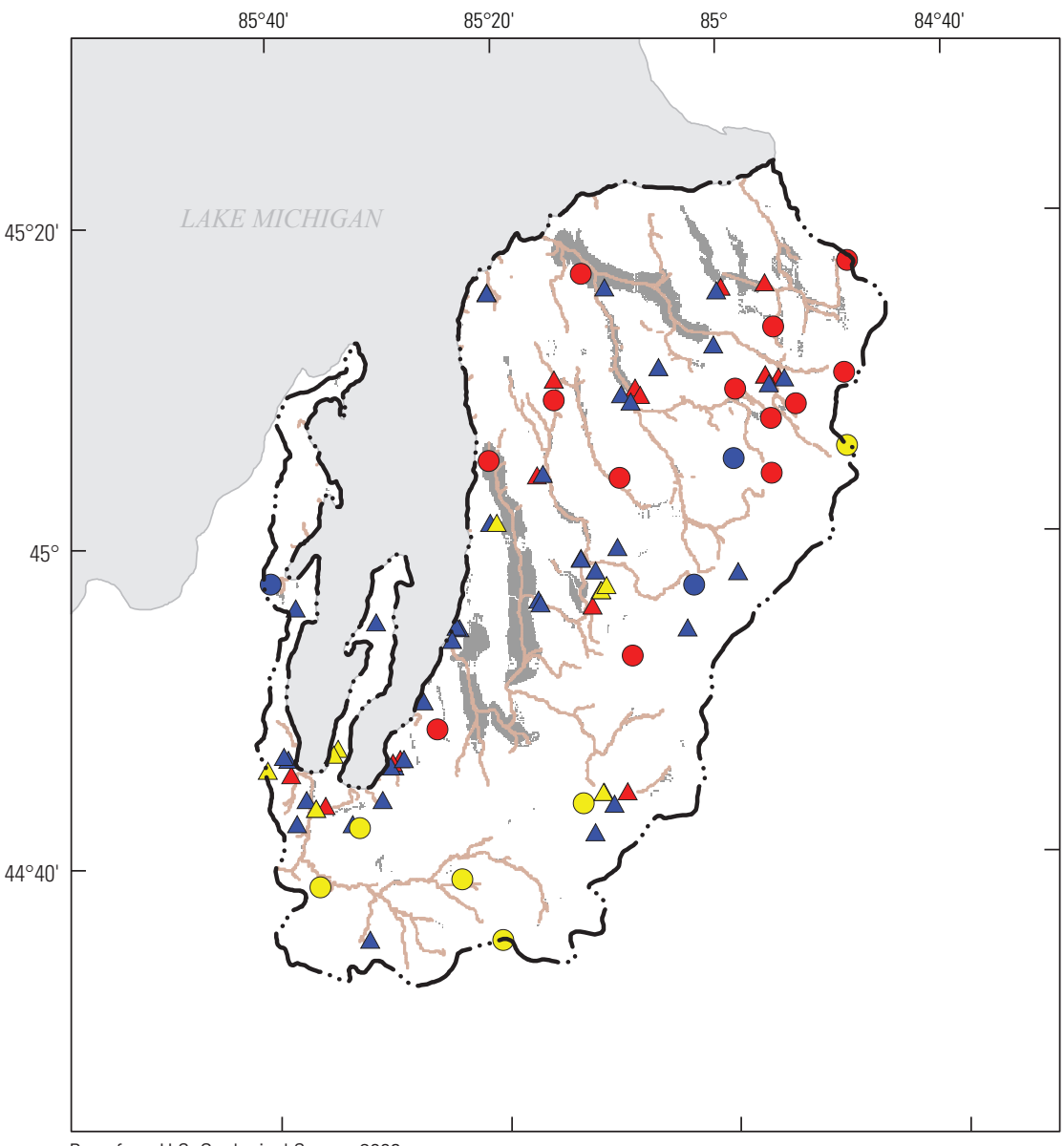

EXPLANATION

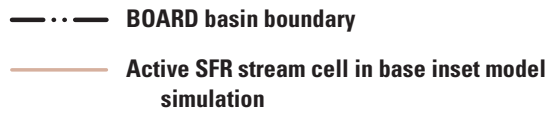
simulation

Active in-basin DRN water-body cell in base inset model simulation

Seeded well for example inset-model simulationGlacial transmissivity at least 500 square feet per day

Open to layer 1

Open to layer 2

Open to layer 3

Existing high-capacity glacial well

$\Delta \quad$ Open to layer 1

- Open to layer 2 (bottom layer, if multi-node)

$\triangle \quad$ Open to layer 3 (bottom layer, if multi-node)

Base from U.S. Geological Survey, 2006

$1: 250,000$ digital data

Figure 26. Maps for each inset model showing the locations of seeded wells by layer for an example simulation, along with the locations of existing glacial wells by layer, active water body cells, and the active stream cells for $A, \mathrm{KALA} ; B, \mathrm{BOARD}, C, \mathrm{UPFOX}$; $D$, MANI; and E, WHITEDAM. (SFR, streamflow routing package; DRN, drain package.)—Continued 
C. UPFOX

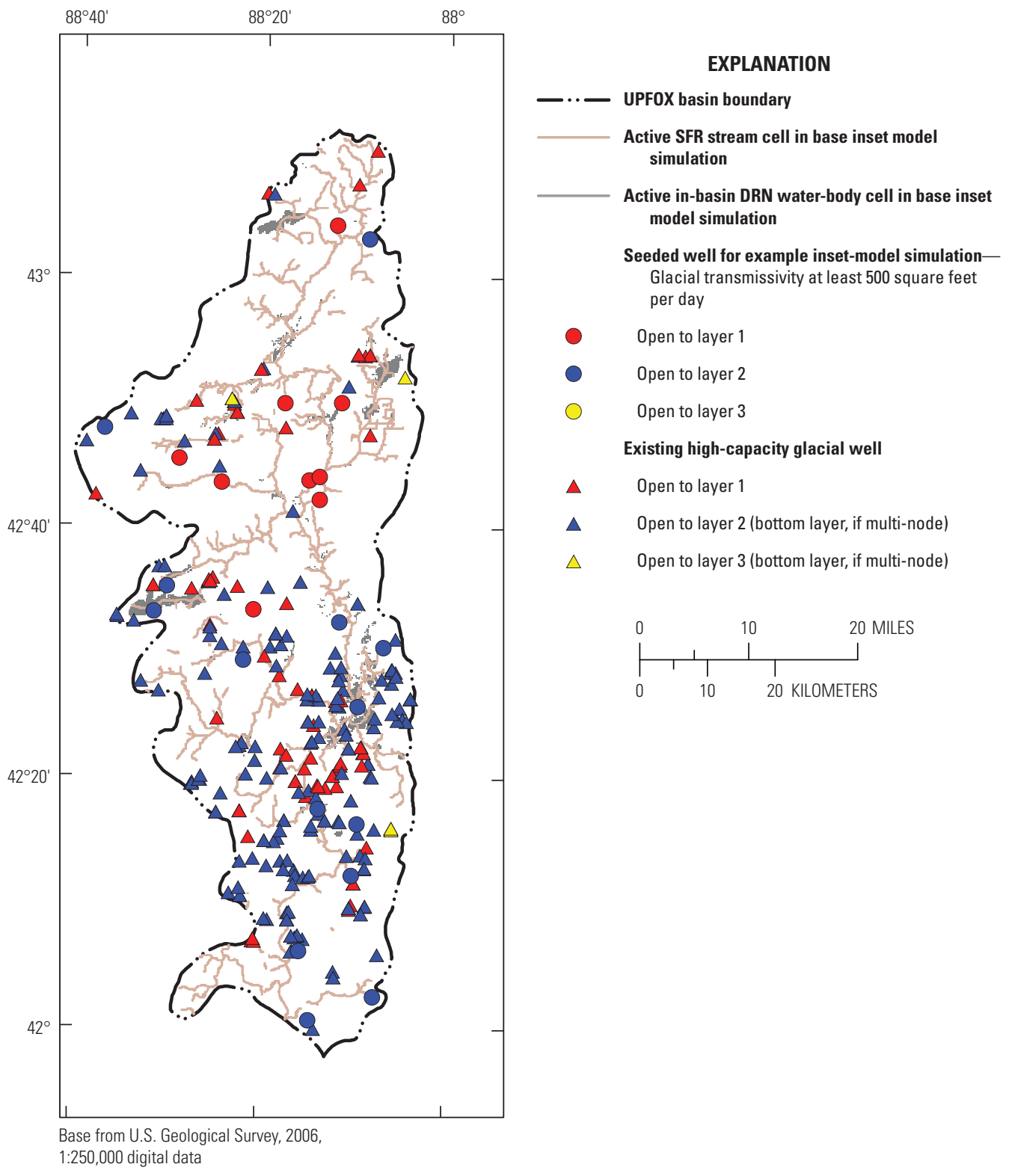

Figure 26. Maps for each inset model showing the locations of seeded wells by layer for an example simulation, along with the locations of existing glacial wells by layer, active water body cells, and the active stream cells for $A, \mathrm{KALA} ; B, \mathrm{BOARD}$; $C$, UPFOX; $D$, MANI; and $E$, WHITEDAM. (SFR, streamflow routing package; DRN, drain package.)—Continued 


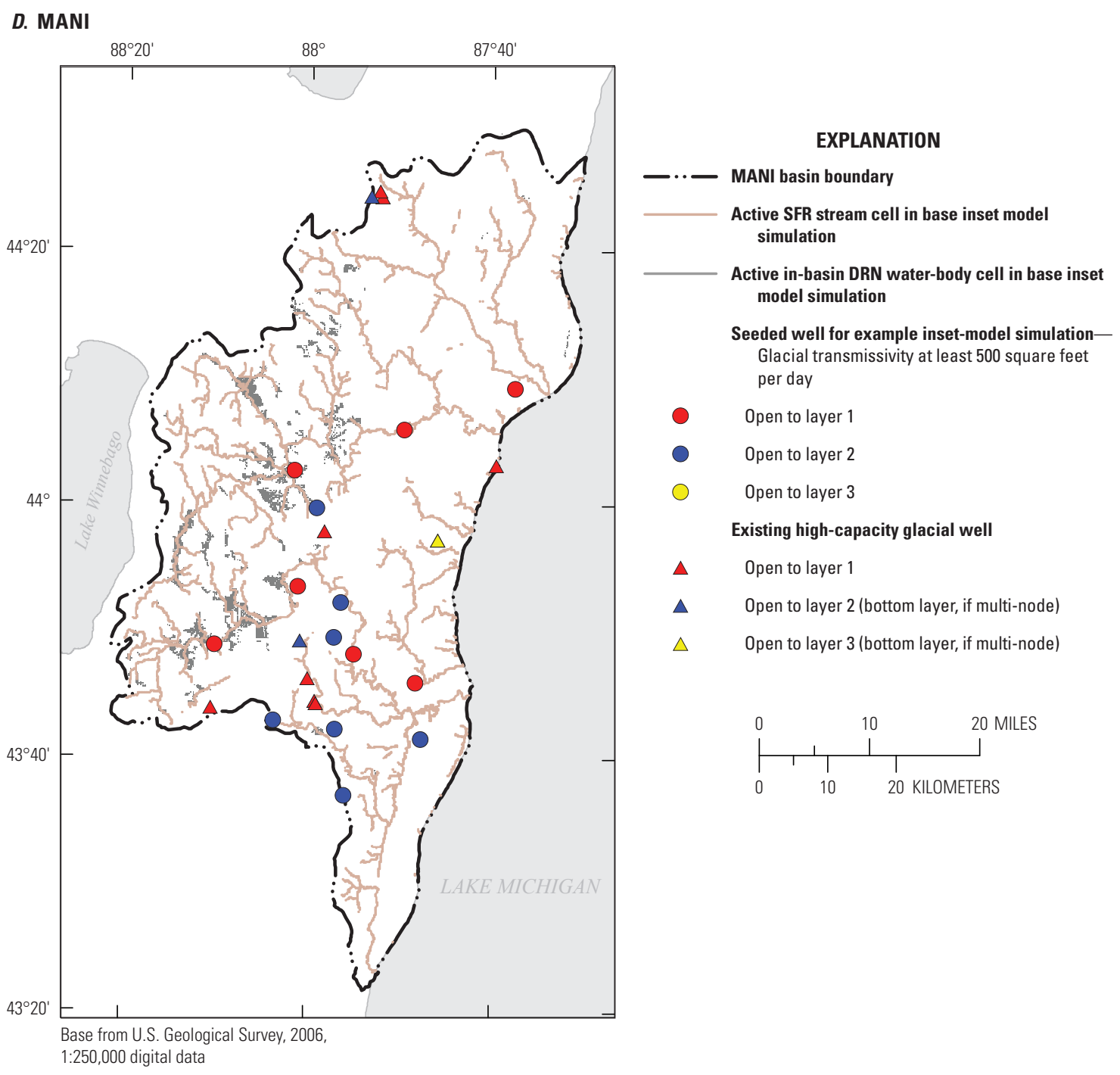

Figure 26. Maps for each inset model showing the locations of seeded wells by layer for an example simulation, along with the locations of existing glacial wells by layer, active water body cells, and the active stream cells for $A$, KALA; $B, B O A R D ; C$, UPFOX; $D$, MANI; and E, WHITEDAM. (SFR, streamflow routing package; DRN, drain package.)—Continued 


\section{E. WHITEDAM}
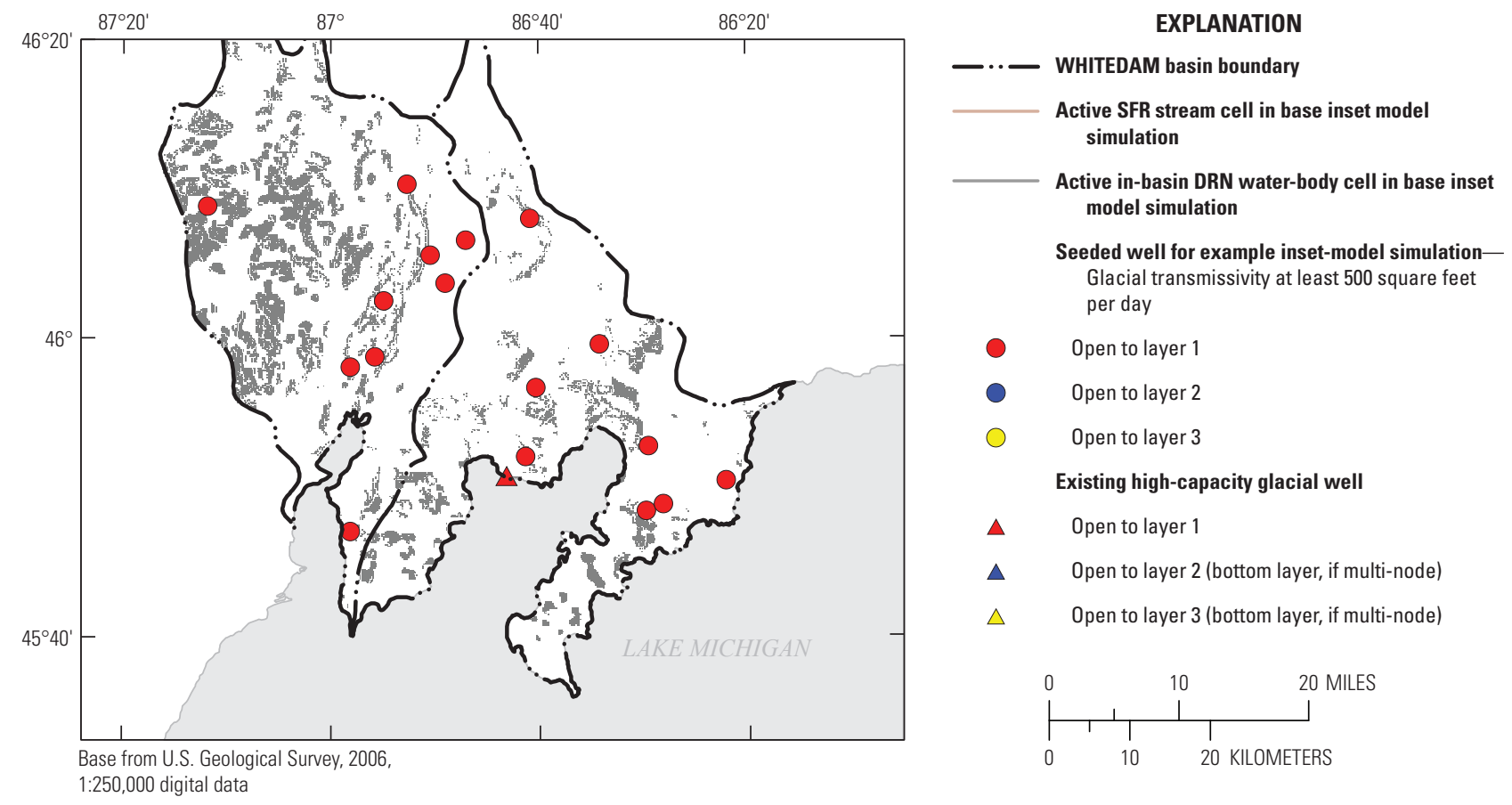

Figure 26. Maps for each inset model showing the locations of seeded wells by layer for an example simulation, along with the locations of existing glacial wells by layer, active water body cells, and the active stream cells for $A, K A L A ; B, B O A R D$; $C$, UPFOX; $D$, MANI; and E, WHITEDAM. (SFR, streamflow routing package; DRN, drain package.)—Continued

seeded) always depend on the rate sustained by the simulation rather than the assigned rate input to MODFLOW. Given the objective of this modeling effort - to support metamodeling of controls on groundwater age - it is not a problem if the assigned rate is not achieved at a given well. It is important that the simulated age results are correlated correctly with conditions arising from the actual pumping rates sustained by the model simulations.

\section{Particle Tracking with MODPATH6}

The program MODPATH6 (Pollock, 2012) was used to track particles through the MODFLOW models to quantify the traveltimes, or groundwater age (hereafter generally referred to as "age"), of water through the saturated sediments. The purpose of the particle tracking was to simulate age distribution for both the existing and seeded wells for each of the inset model basins. An understanding of age distributions of groundwater discharged to wells can help in understanding and predicting possible changes in water quality in wells.

The only additional parameter needed for the MODPATH simulation that was not input to the MODFLOW simulations is the effective porosity of the hydrostratigraphic units. The values for effective porosity were set to a single representative value for the unlithified (glacial) layers equal to 0.20 and a single value for all the bedrock layers equal to 0.08 . The bedrock value is typical of porosity values estimated using geophysical methods for bedrock units in southeastern Wisconsin (Carlson, 2001). The glacial value is typical of porosity values estimated for unconsolidated material (Kresic, 2007). Note that since the MODFLOW simulations are steady state, the age computed by MODPATH is directly proportional to the value used for effective porosity.

Across the target basins, the age distribution was estimated using MODPATH for 8,222 well locations. In order to simulate the age distribution for a single well, 1,000 particles were randomly positioned on the outside of a cylinder representing a well screen. Each well was assumed to be in the center of the cells with a radius of $0.5 \mathrm{ft}$ screened across the entire thickness of the saturated sediments in the model layer or layers designated for the well. The particles were then moved to the edge of the cell using the technique described in Starn and others (2012). The technique is used to minimize the effect of wells, which act as weak sink cells. A weak sink occurs when a sink does not capture all the flow entering the cell, which can lead to anomalous results.

Particles were backtracked through the cell containing the well on the basis of the approximate analytical solution presented by Zheng (1994). The positions of the particles on the cell boundary were translated into the starting locations 


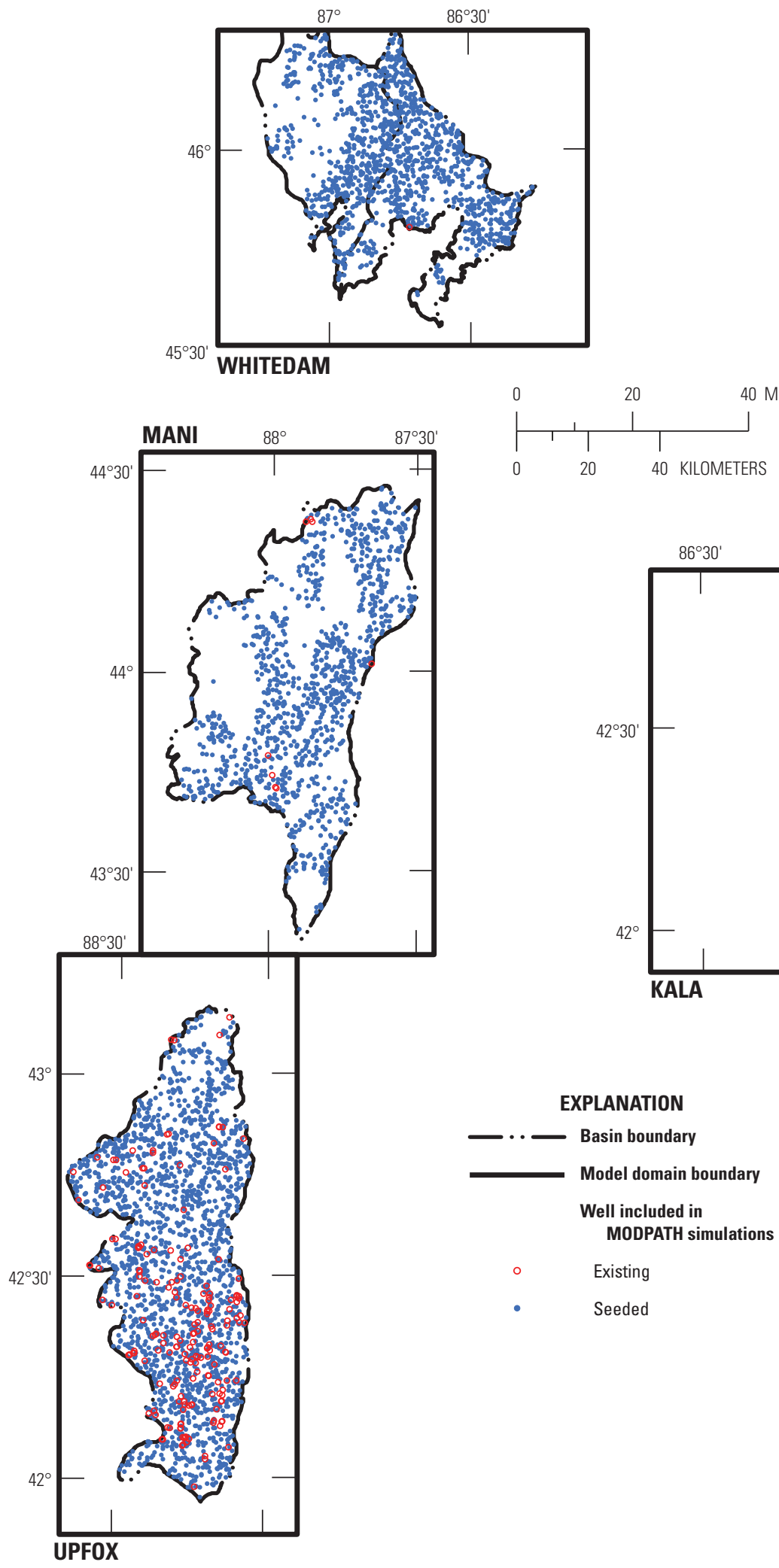

Base from U.S. Geological Survey, 2006, 1:250,000-scale digital data

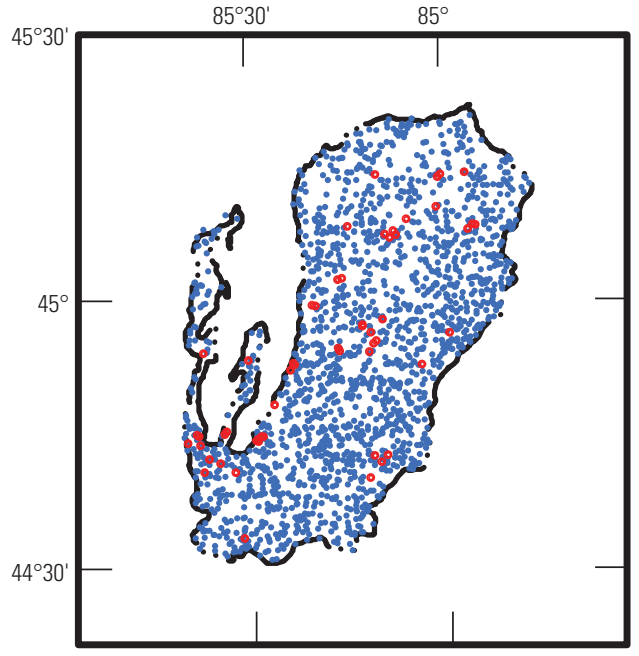
BOARD

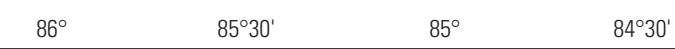


file used by MODPATH. The particles were then backtracked through the MODFLOW domain until they reached a recharge boundary, such as the water table or a losing stream. The reported traveltimes were adjusted to add the time required to move the particle from the well screen to the boundary of the cell containing the well.

\section{Age Metrics of Groundwater Discharge to Wells}

The traveltimes for each of the individual particles were grouped to create an age distribution for the well. Four metrics were used to characterize the age distributions for each well (table 11). The median age of all the discharge is computed; the median was used here rather than the mean because the age distributions can have long tailed distributions where only a few particles can greatly influence the mean value whereas the median better represents the central tendency of all the particles. An age threshold of 65 years was used to divide the age distribution into old and young fractions. This value is somewhat arbitrary but represents the time at the beginning of the 1950s when anthropogenic contaminants started becoming more of a groundwater problem. This time frame also corresponds to the period when atmospheric levels of tritium first increased owing to nuclear testing then decreased; tritium is a common tracer used to estimate groundwater age. The fraction of ages less than the threshold of 65 years (young faction) was recorded as one of the metrics of age. The other two age metrics are the median age of the young fraction of the water and the median age of the old fraction of the water. If the water in a well was either all younger than 65 years or all equal to or older than 65 years, the median age was assigned 65 years for the fraction that did not contain any particles. The young age is probably more relevant for anthropogenic contaminant issues, whereas the old age is more relevant for natural contaminant issues.

Particle tracking was done, and the age metrics were computed, for the existing and seeded wells for each of the five inset models. Well locations of seeded and existing wells, as well as their position relative to the active streams in the

Table 11. Age metrics of groundwater discharge to glacial wells, simulated by MODPATH.

[Young water is less than 65 years old; old water is equal to or more than 65 years old]

\begin{tabular}{cll}
\hline $\begin{array}{c}\text { Age } \\
\text { metric }\end{array}$ & \multicolumn{1}{c}{ Name } & \multicolumn{1}{c}{ Definition } \\
\hline a & FracYoung & Young fraction of well discharge. \\
b & MedianYoungAge & $\begin{array}{c}\text { Median age of young fraction of well } \\
\text { discharge. }\end{array}$ \\
c & MedianOldAge & $\begin{array}{c}\text { Median age of old fraction of well } \\
\text { discharge. }\end{array}$ \\
d & MedianAge & Median age of all well discharge. \\
\hline
\end{tabular}

model, are shown in figure 26. In the KALA inset model, the existing wells appear more often in the western part of the HUC 8 basin, seem to occur more often near streams, and are often concentrated in pumping centers. The seeded wells are much more dispersed across the landscape. Figure 27 shows the well locations for all five insets Similar to the KALA inset model, the UPFOX and BOARD inset models show the existing wells more clustered than the seeded wells within their respective HUC8 basins. The WHITEDAM inset model has only one and MANI inset has only eight existing wells within their HUC8 basins. The MANI and WHITEDAM basins have some sizeable areas with no seeded wells. This is because the unconsolidated sediments in these areas do not have the transmissivity to readily support pumped wells; the rules used to assign the seeded wells, as described in the "Seeded Glacial Wells" section, serve to avoid placing wells in low-transmissivity areas. The two populations of wells yield a picture of what the aquifer has supported and presumably could support. Note that some of the locations of the seeded wells coincide with surface-water features such as lakes and wetlands and likely would be difficult locations to actually drill a well, but they are nevertheless included to allow for consideration of the full range of conditions which contribute to the factors important for predicting the age metrics for wells.

Figure 28 presents an example of what the MODPATH results look like spatially for one run with seeded wells in the KALA basin. The example run has 24 seeded wells modeled in MODFLOW. The most common configuration for the area contributing recharge (the ending locations for the particles tracked backward to the water table) and the zone of contribution (the projection of the pathlines in the horizontal plane) is a fairly narrow band extending back toward the surface-water basin divides. The area contributing recharge and the zone of contribution delineated by the pathlines generally overlap when viewed from above. This overlap indicates that the pumping amounts are not sufficient to significantly alter the regional groundwater gradients that result from the topography and recharge. There are a few wells with relatively more dispersed areas contributing recharge, a configuration that likely results when the well is located close to basin divides or is subject to high pumping rates.

Two of the wells in figure 28 are accompanied by histograms of the age associated with the MODPATH particles tracked backward from the wells to the water table. These histograms are examples of the detailed output from MODPATH - in one case (fig. 28B) showing the age of discharge at a seeded well, which is mostly older than 65 years, and in another case (fig. 28C), showing the age of discharge at a seeded well, which is mostly younger than 65 years. The western location of well 13980 with the older water has a contributing area that is somewhat removed from the well, whereas the eastern location of well 13981 with the younger water has a contributing area that abuts the well.

The distributions of the age metric values for each of the inset model basins are shown in boxplots in figures $29 A-D$. 


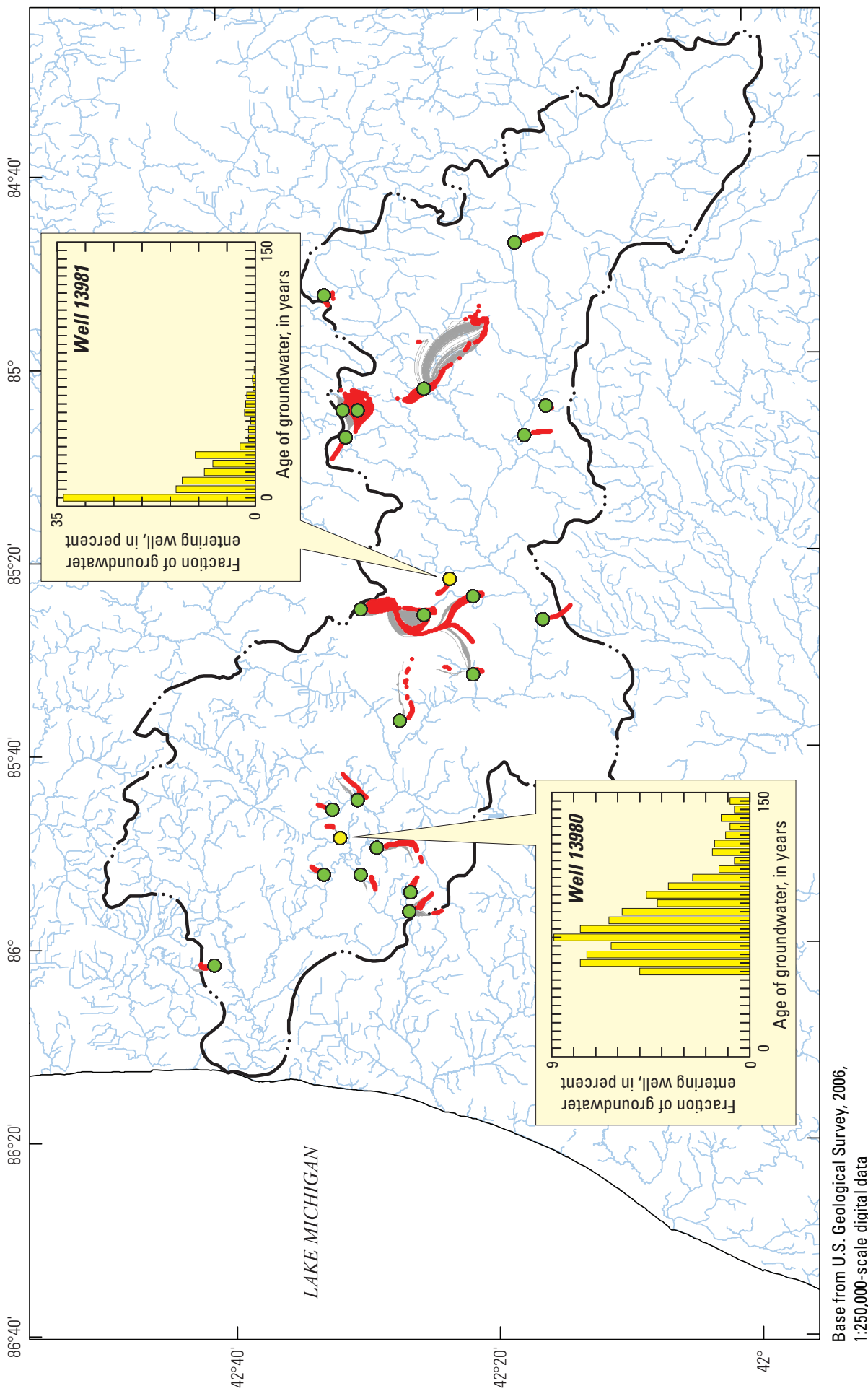

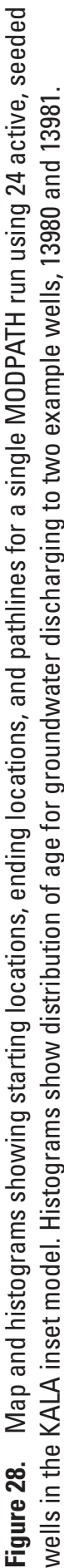



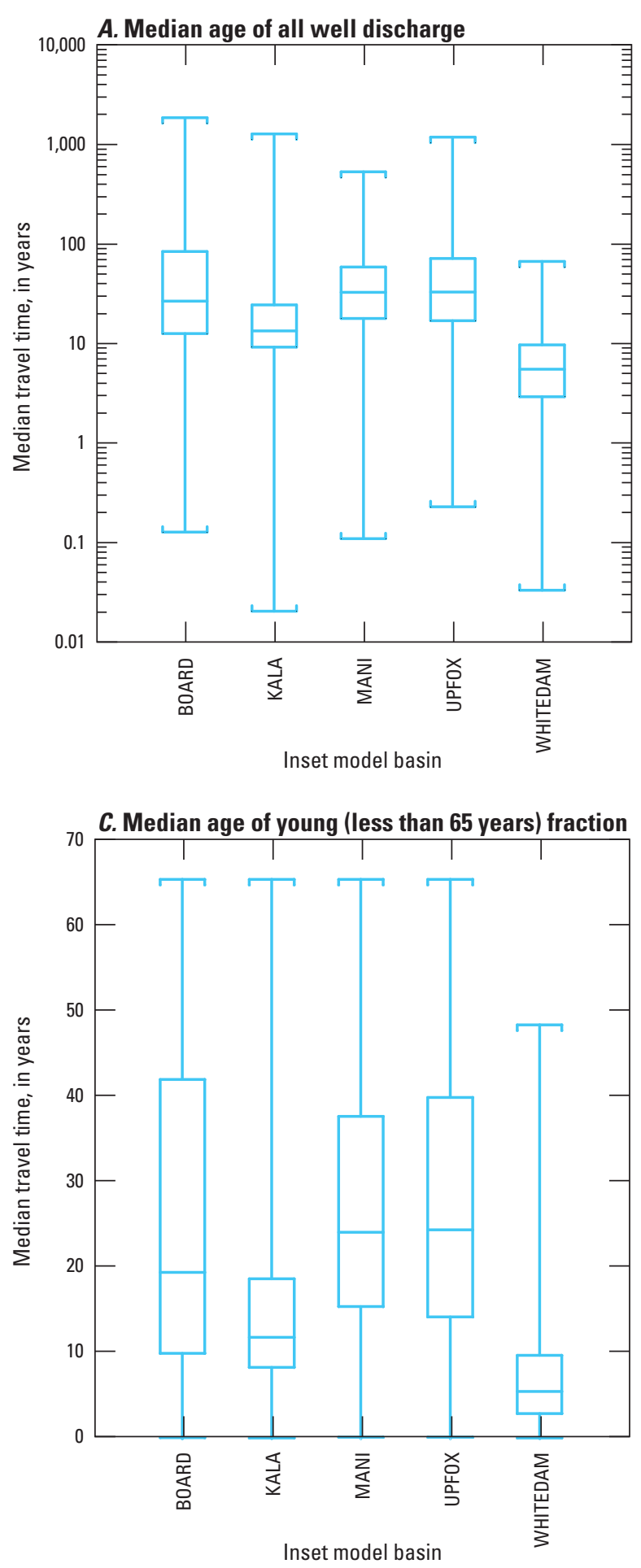

B. Young (less than 65 years) fraction of well discharge

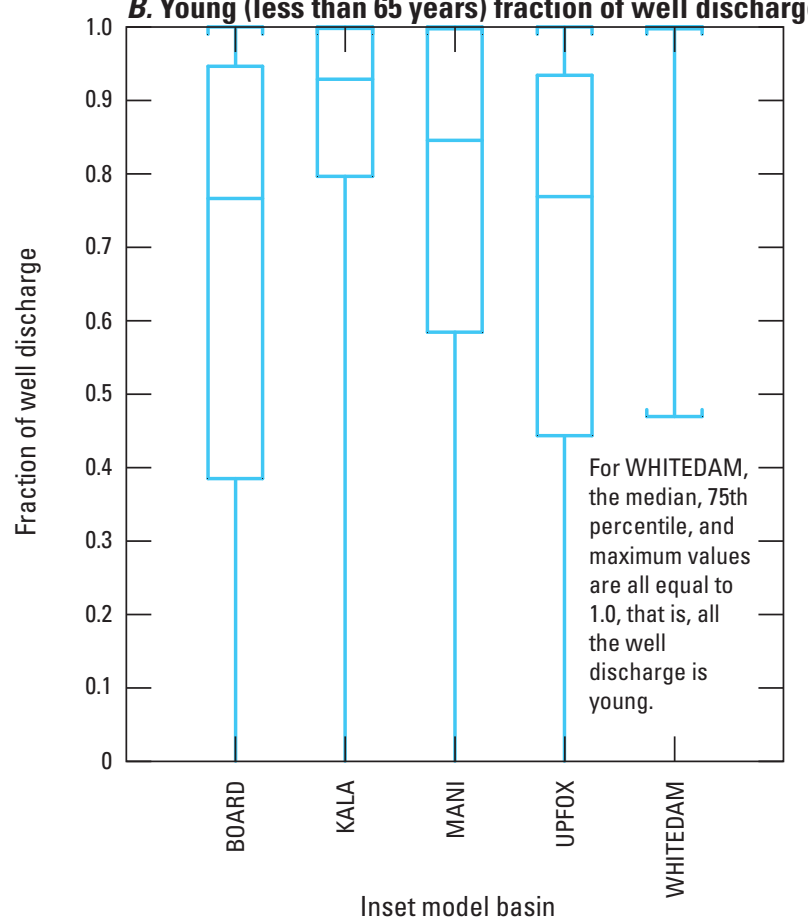

$D$. Median age of old (greater than or equal to

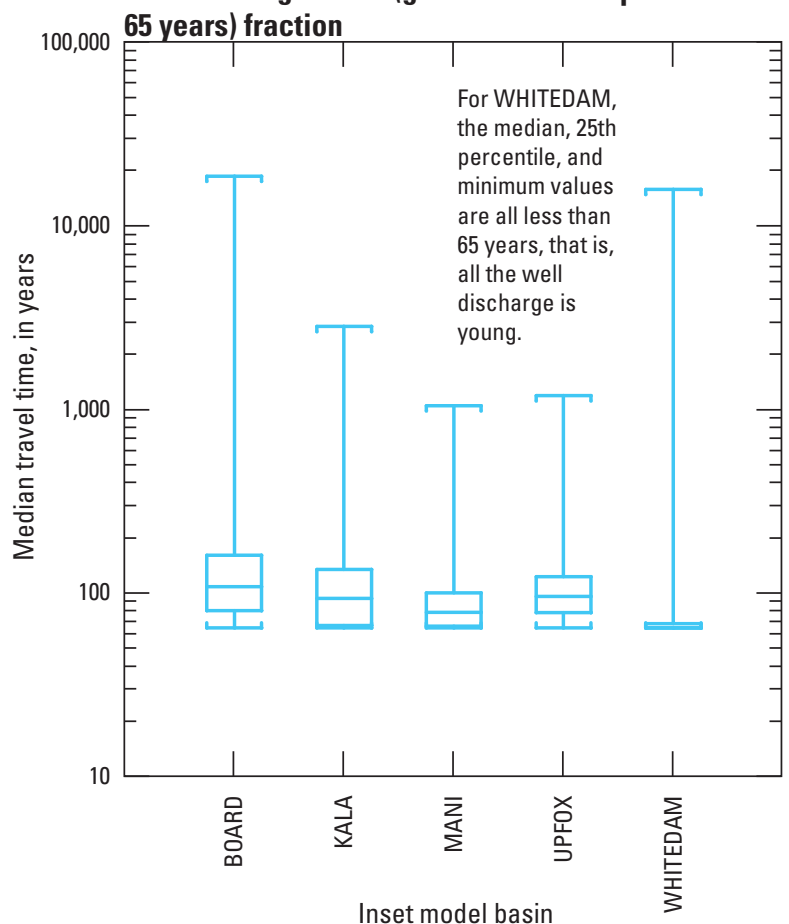

EXPLANATION

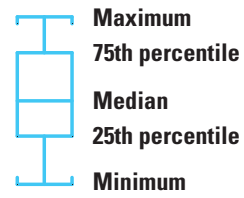

Figure 29. The distribution of the MODPATH age metrics for each inset model. Boxes encompass the entire distribution with the whiskers and caps. The boxes show the 25th and 75th percentiles with the median value shown as a line in the box. $A$, median age of all well discharge; $B$, young (less than 65 years) fraction of well discharge; $C$, median age of young (less than 65 years) fraction; and $D$, median age of old (greater than or equal to 65 years) fraction. 
The boxplots show the full range, the range of the middle 50 percent of the data, and the median values for each metric.

The distributions of the median age of all glacial well discharge are shown in figure $29 \mathrm{~A}$. Note that this distribution is made of the median values from each well; the range of ages across all particles entering the wells is larger than this boxplot shows. The medians of these median ages (that is the expected age value), by target basin, are KALA, 13.3 years; BOARD, 26.7 years; UPFOX, 33.0 years; MANI, 32.6 years; and WHITEDAM, 5.5 years. Wells in the WHITEDAM basin generally discharge the youngest water because most of them penetrate thin glacial deposits, discharging shallow groundwater that mostly moves laterally just below the water table. Elsewhere the contributing water to the wells in the target basins display traveltimes that range over many orders of magnitude. Wells in the BOARD inset model have perhaps the greatest spread with median age values for individual wells ranging from around 1 week to more than 1,000 years.

The distributions of the young fractions for each of the inset models are shown in figure 29B. The WHITEDAM basin again has the youngest water; nearly 75 percent of its existing and seeded wells discharging entirely young water. The other target basins have at least some wells with all young water and others with all old water, although the middle quartiles of the distribution correspond to mixtures of young and old water.

The median ages of the young and old fractions are shown in figures $29 C-D$. The WHITEDAM basin again is distinctive owing to the young age of its young fraction; however, the mean old fraction is very old in at least one well. The KALA and BOARD basins tend to have younger young fractions and older old fractions than the MANI and UPFOX basins.

The spatial distribution of the young fraction for all 8,222 glacial wells simulated in the target basins is shown in figure 30. Figure 31 shows the spatial distribution of the young fraction but only for the wells where the open interval does not cross the simulated water table at the top of the saturated system. The relation of the open interval of the well to the water table is a more physically based predictor than the absolute depth of the well (that is, the assigned model layer) because the saturated depth to the top of the well open interval controls the vertical distance recharge must travel from the water table to the well screen. About 40 percent of the existing and seeded wells are open below the simulated water table elevation (sometimes open just below the water table and sometimes open as much as $300 \mathrm{ft}$ below the top of the saturated system). All 3,268 wells open below the water table are in layers 2 and 3. (Another set of 685 wells are open to layers 2 and 3 but cross the water table because it is sufficiently deep at those locations.) The expectation that the age of the well water will tend to be greater for wells open below the water table is borne out by the MODPATH results. The median age of the discharge to wells open to the water table (not shown in fig. 31 ) is 11 years, whereas the median age of the discharge to wells open below the water table is 52 years. This large discrepancy is consistent with the finding that most of the wells discharging older water are the deeper wells open below the water table, shown in figure 31 as red dots. It is also true that some deeper wells discharge young water; those wells are shown as blue dots in figure 31 .

Figures 30 and 31 confirm the findings, shown in boxplots, that glacial wells in the WHITEDAM basin discharge water that is almost exclusively young. The figures show that most of the wells in the WHITEDAM basin are in the watertable layer (layer 1), so it follows that they discharge mostly young water. The figures also indicate that the UPFOX and MANI basins contain many wells with smaller fractions of young water in their eastern extent close to Lake Michigan. These areas typically are marked by fine-grained, lower transmissivity sediments in the upper part of the glacial sequence; as a result, the open intervals of wells are generally set deeper, leading to older ages of water. It is also possible that upward vertical gradients from the bedrock in the eastern areas of the UPFOX and MANI basins (fig. 22) are associated with longer, more regional pathlines carrying older water to shallow wells.

Most of the wells in the KALA basin discharge young water, but there is a subset of wells distributed throughout the basin that pump older water. The southern part of BOARD basin has many glacial wells associated with older water. Most of these wells are open below the simulated water table. The BOARD inset area has some of the thickest, most transmissive sediments in the LMB area, especially in the southern part of the basin. The rules for placement of the seeded wells favored placement of wells deeper in the system when high enough transmissivity is present. Because that is the case with the southern part of the BOARD basin, most of the seeded wells in that area are in the deeper glacial layers, which results in older water in these wells because they tend to be open below the water table. Although the algorithm for locating the seeded wells did not place shallower wells in much of the BOARD basin, the aquifer would nevertheless support pumping in much of the basin from layer 1 and layer 2 wells that cross the water table.

Similar overall patterns for the median ages of the young and old age fractions are shown in figures 32 and 33, respectively. For the median age of the young fractions, there is less contrast in the older versus younger areas especially in the UPFOX and MANI basins. For the median age of the old fraction, the KALA basin is marked by the oldest age of the old fraction in its western part.

Recall that all the MODPATH calculations were conducted with an effective porosity of 0.20 assigned to glacial layers and 0.08 assigned to bedrock layers. Across all five inset model basins, 77.3 percent of the glacial wells draw groundwater that circulated entirely in the glacial layers and did not cross into the bedrock. Because of the steady-state nature of the simulations, raising or lowering the effective porosity of the glacial layers would automatically have a linear effect on the traveltime for the groundwater discharge to these wells (that is, halving the glacial effective porosity to 0.10 would halve the traveltimes and halve the age of groundwater discharge). 


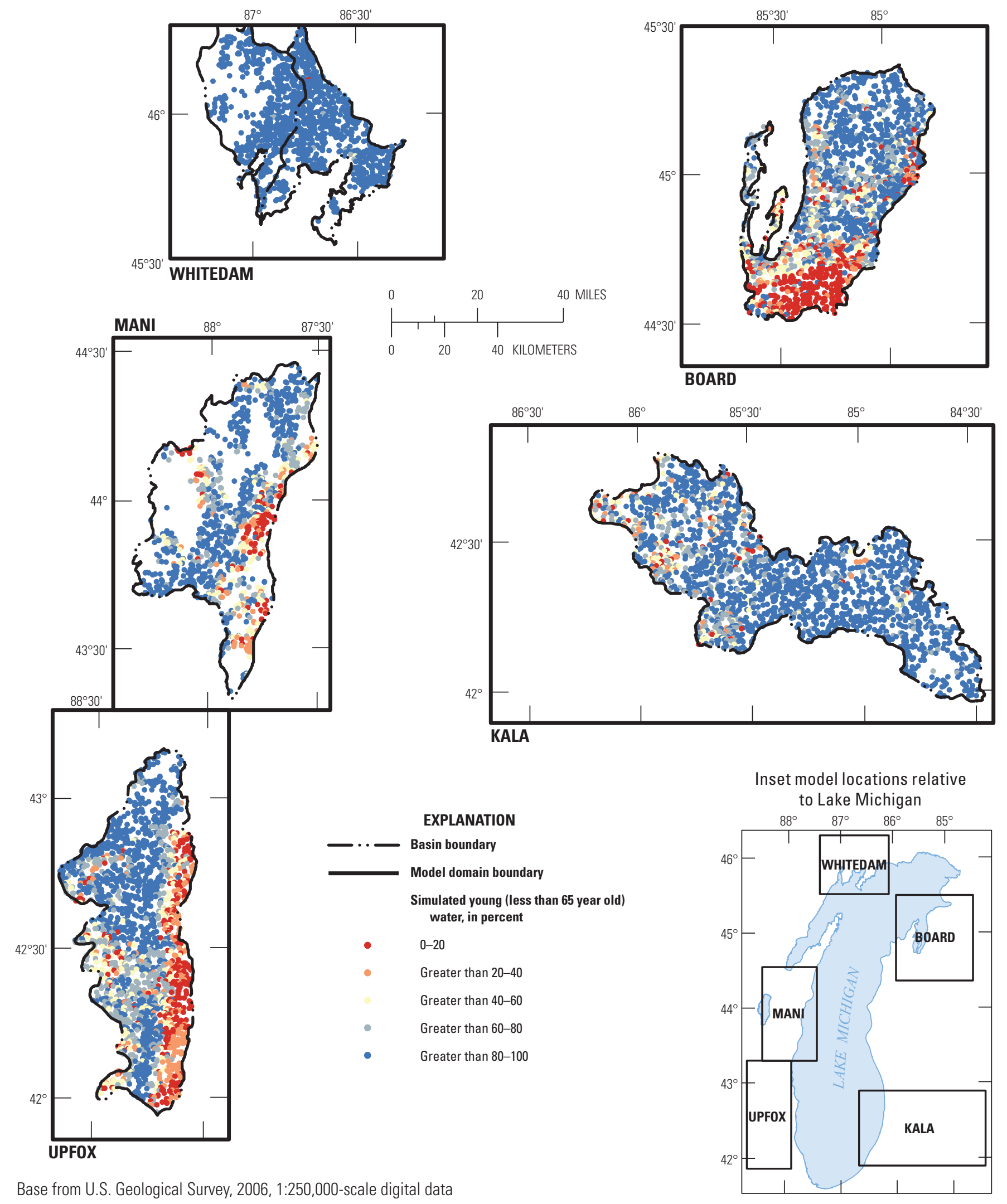

Figure 30. The location and young (less than 65 years) fraction simulated by MODPATH for glacial wells within the inset model target 8-digit hydrologic unit code (HUC8) basins. 


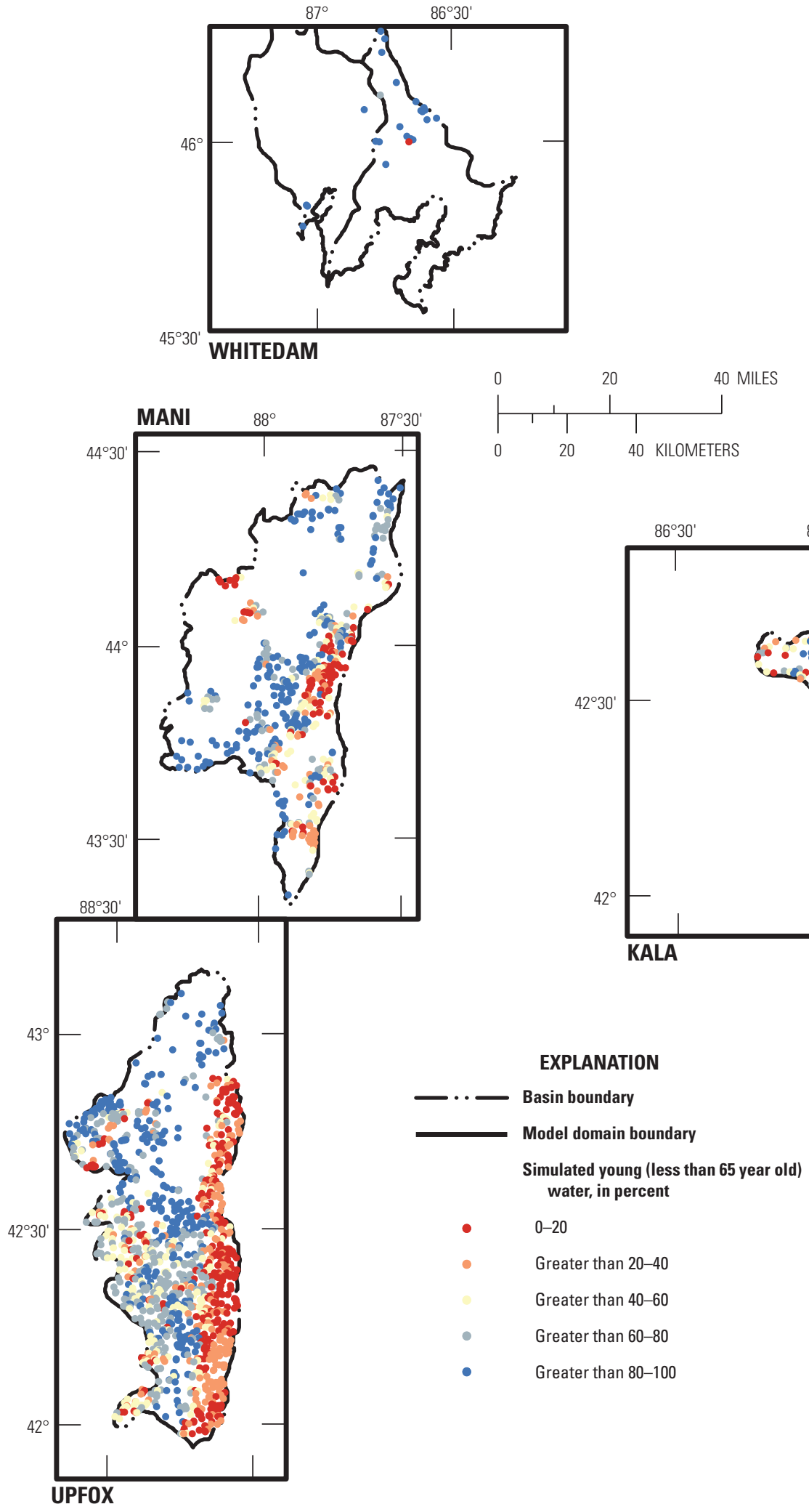

Base from U.S. Geological Survey, 2006, 1:250,000-scale digital data

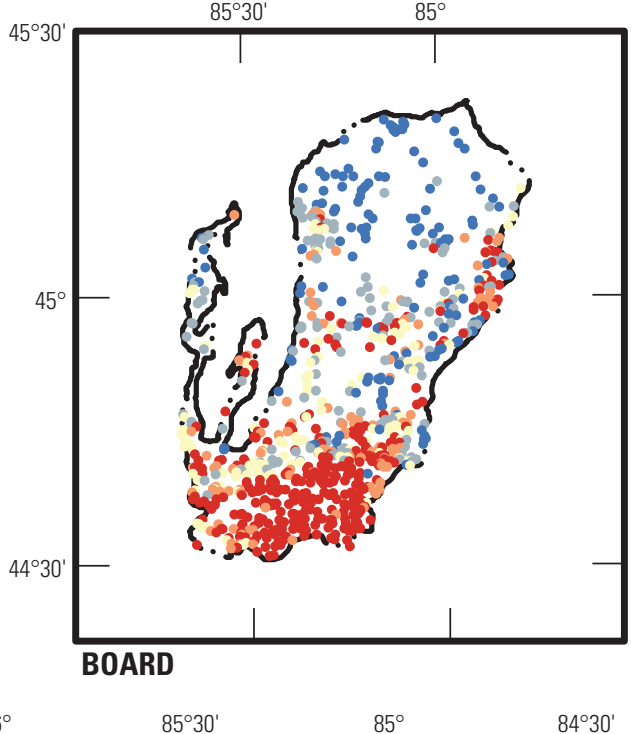

Inset model locations relative to Lake Michigan

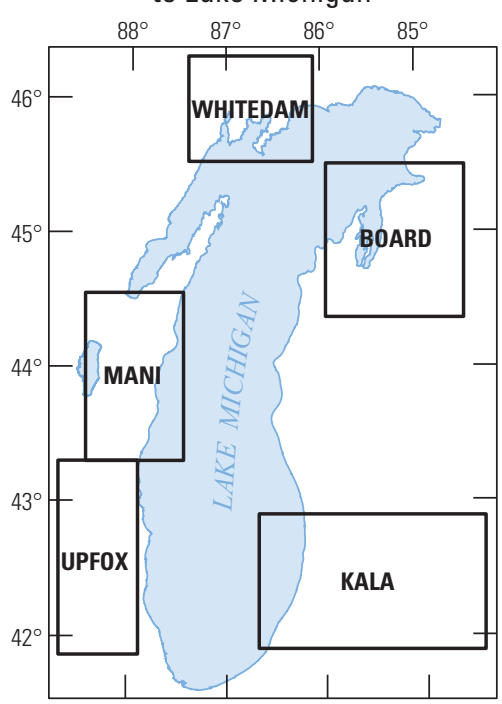

Figure 31. The location and young (less than 65 years) fraction simulated by MODPATH for glacial wells within the inset model target 8-digit hydrologic unit code (HUC8) basins with open intervals below the water table. 


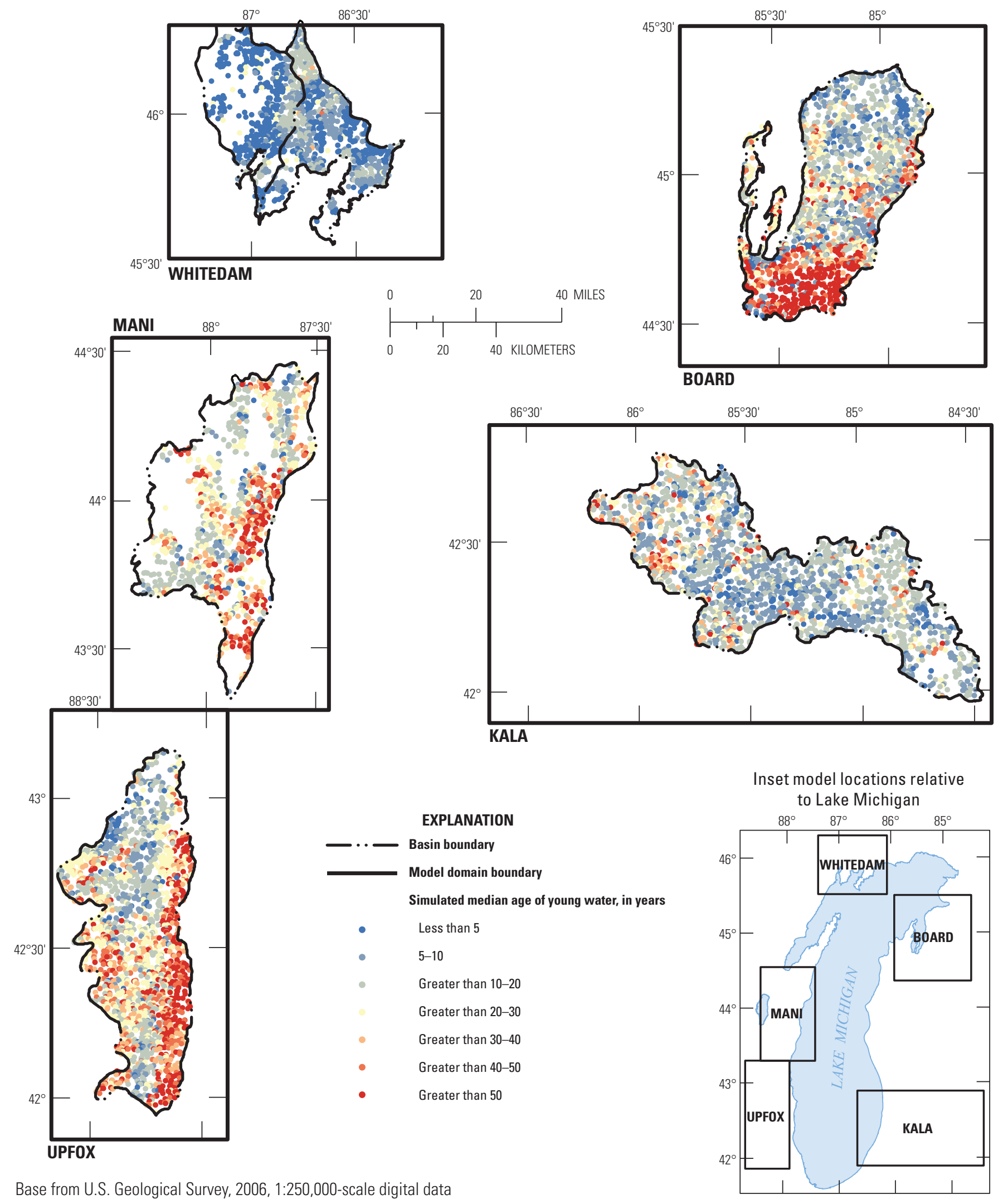

Figure 32. The location and simulated median age of the young (less than 65 years) fraction of discharge for each well for all inset model target 8-digit hydrologic unit code (HUC8) basins. 


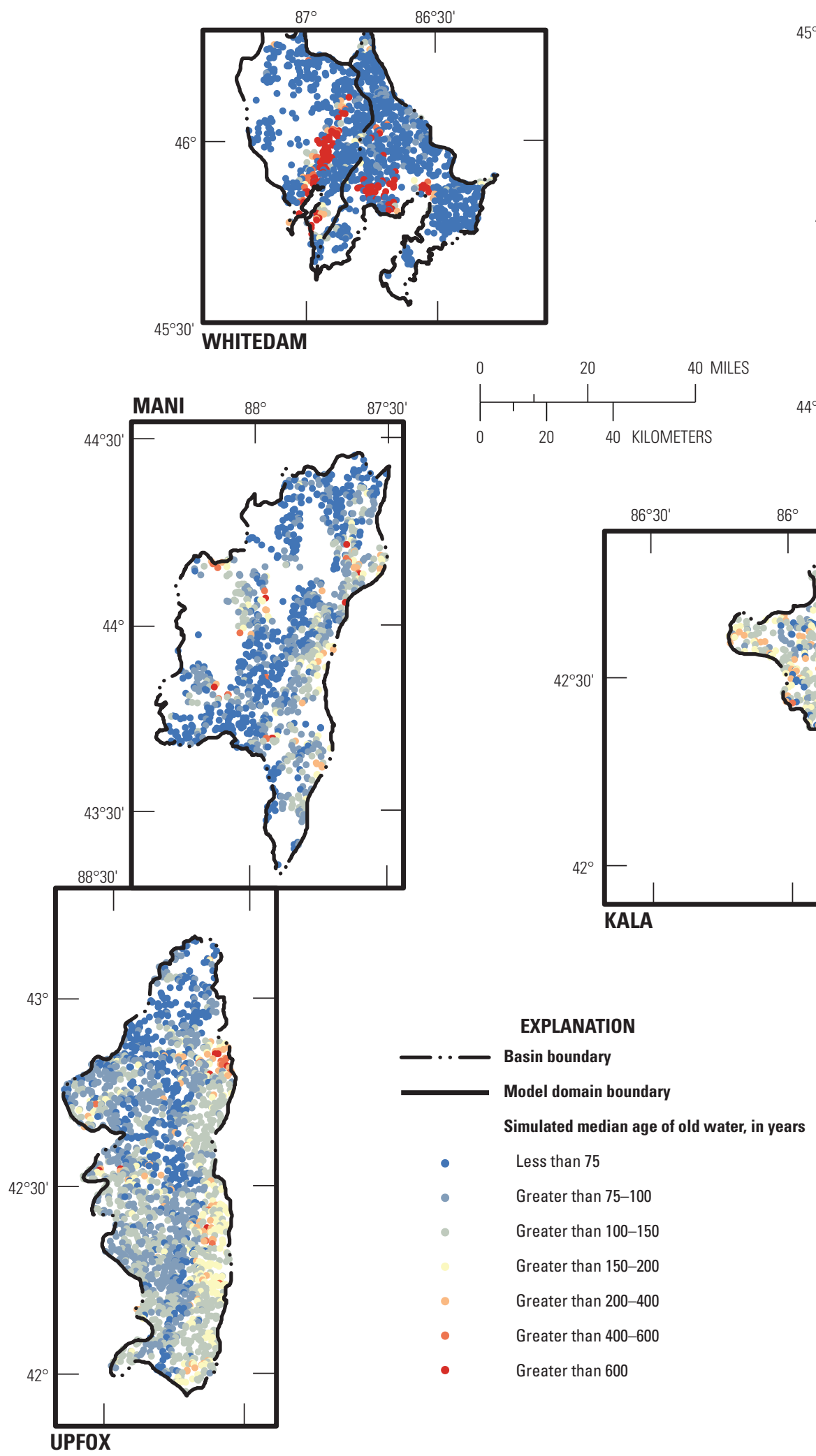

Base from U.S. Geological Survey, 2006, 1:250,000-scale digital data

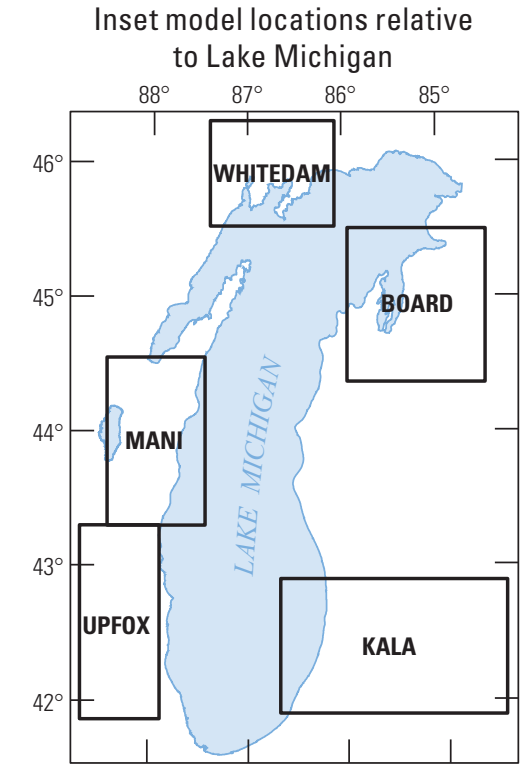

Figure 33. The location and simulated median age of the old (greater than or equal to 65 years) fraction of discharge for each well for all inset model target 8-digit hydrologic unit code (HUC8) basins. 
Of more interest are the wells that were simulated to draw water that circulates through both glacial and bedrock layers. These wells, 22.7 percent of all wells, potentially discharge water with a greater range of ages than other wells. To test the sensitivity to the value of effective porosity in the bedrock layers, MODPATH simulations were also performed assuming a value of 0.02 rather than 0.08 for the effective porosity in the bedrock layers. Because of the steady-state nature of the simulations, lowering the effective porosity has the effect of decreasing traveltimes through the bedrock and, thus, potentially lowering the overall age of discharge to wells. For this sensitivity simulation, the age was lowered only relative to the original simulation, if there was flow through the bedrock layers, because the effective porosity in the glacial layers was unchanged. Of the individual basins, BOARD basin had the lowest percentage of wells with some water traveling through the bedrock, only 0.6 percent. BOARD is the area with the most thick, transmissive sediments, so this result is not surprising. The percentage of wells with at least some pathlines entering the bedrock in UPFOX basin was 12.8 percent; WHITEDAM, 21.8 percent; KALA, 31.5 percent; and MANI, 52.8 percent.

As an illustration of how the age metrics vary when the effective porosity in the bedrock is changed is shown in figure 34 as a comparison of the young fraction age metric for wells across all basins for the two different values of effective porosity for the bedrock. Most of the points ( 88 percent) fall on the 1:1 line, indicating for these instances negligible influence of bedrock groundwater flow on the calculated discharge age. For the points off the 1:1 line, the difference in the calculated young fraction can be small or large. Overall, it appears that the influence of bedrock groundwater flow on the age pattern for existing and seeded glacial wells is not large. For completeness, however, certain predictors prepared for the prospective metamodel (for example, the ratio of glacial to

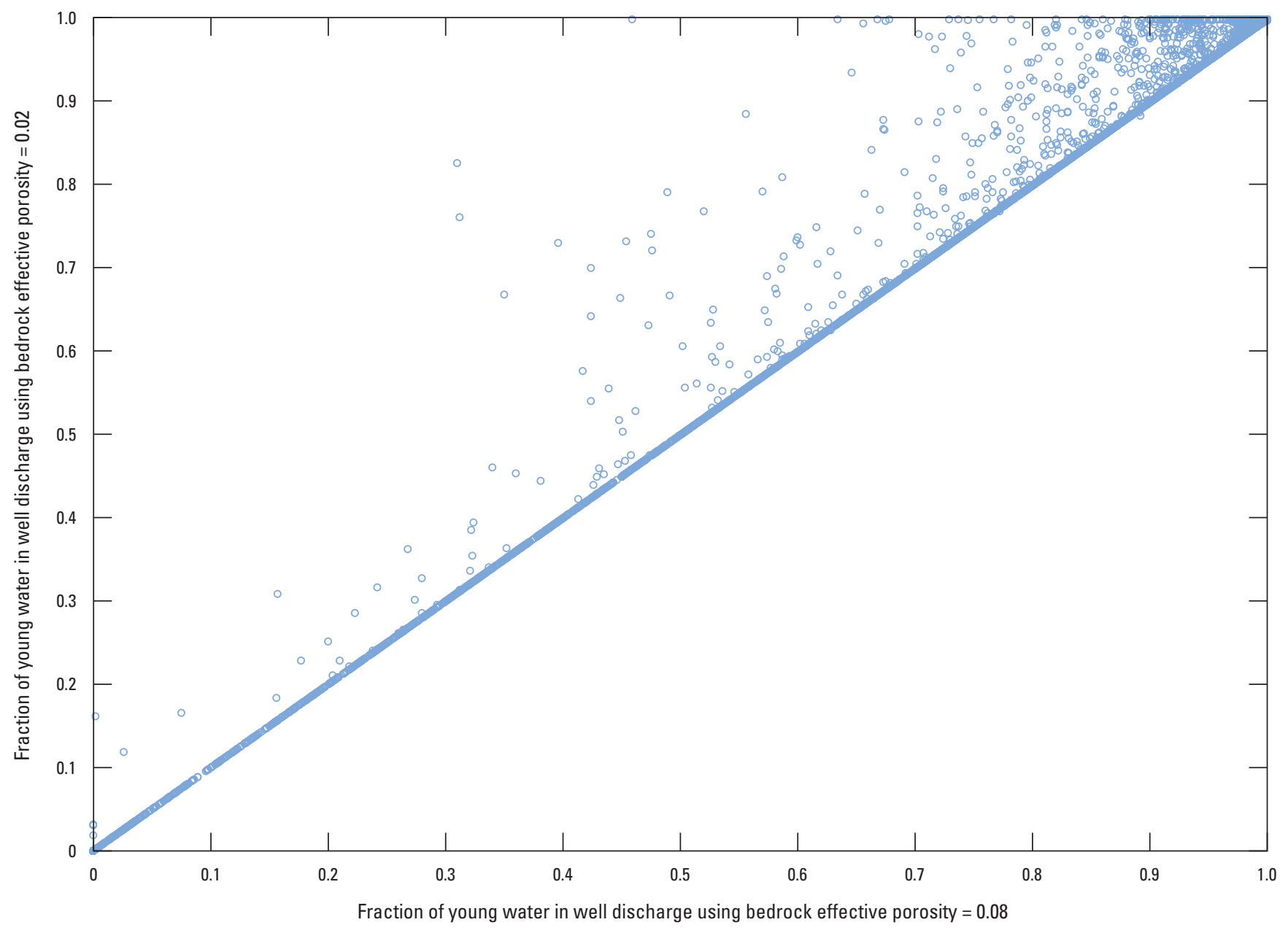

Figure 34. Graph comparing the simulated values of young (less than 65 years) fraction of well discharge across all inset model target 8-digit hydrologic unit code (HUC8) basins using bedrock effective porosity values of 0.08 and 0.02 . 
shallow bedrock transmissivity) are intended to be sensitive to any bedrock influence on age.

\section{Support for Statistical Modeling of Groundwater Age at Glacial Wells}

Metamodels offer the possibility of distilling the physics of a numerical MODFLOW model into statistical correlation structures inherent in the input and output so that its findings potentially can be extended outside the MODFLOW domain. Metamodels are attractive for decision-support tools, where the goal is rapid application to management problems over large areas. The first step in this process is to demonstrate the ability of the metamodel to emulate one or more findings of interest within the numerical model domain despite employing few explanatory variables (Fienen and others, 2015). The second step is to translate the explanatory variables used in the metamodel to variables that can be readily mapped across the landscape, thereby allowing it to be applied widely. To emulate a MODFLOW model, it is necessary to extract the metamodel explanatory variables, or predictors, directly from the MODFLOW model. To apply the metamodel outside the training application represented by the MODFLOW model domain, it is necessary to substitute predictors from publicly available databases (for example, from geographic information system [GIS] coverages) for the MODFLOW-generated predictors. It is also helpful to demonstrate the transferability of the MODFLOW-emulated metamodel outside the training area by providing some kind of test using, for example, a second MODFLOW model (Feinstein and others, 2017).

This study was intended to support the first step in the development of metamodels for the groundwater age distribution of discharge to shallow glacial wells. In the following sections the MODFLOW-candidate predictors and age metrics in support of a prospective metamodel are defined and evaluated.

\section{Candidate Predictors Extracted from Inset Models}

The MODFLOW-generated predictors that would carry explanatory weight for a metamodel of groundwater age at the existing and seeded glacial wells are not known ahead of time. The strategy adopted in this study was to construct an extensive list of candidate predictors and allow the correlation procedures embedded in the statistical mechanics of the metamodel to determine which predictors are important. One condition limits the list of candidate predictors - they must not only be extractable from the MODFLOW models, but also be available from independent databases. Once the important predictors are determined, the second phase of the metamodeling process, that is, populating the predictors in areas outside the model domains, can be performed more efficiently. Both steps of the metamodeling process - creating the statistical model based on the MODFLOW/MODPATH simulations and applying the metamodel outside the MODFLOW domains - are subsequent to the construction and application of the MODFLOW models documented in this report.

The predictors selected to explain groundwater age at existing and seeded wells fall into several classes (table 12). Some involve the characteristics of the glacial well (for example, pumping rate), the relation of the well to the surrounding aquifer (for example, depth below water table of the open interval), the proximity of the well to surface water, and competition from nearby shallow wells (for example, the pumping rate at the closest competing shallow well). Other predictors are related to local hydrogeology (for example, recharge and glacial saturated transmissivity) or the surfacewater network (for example, stream density). Most of these variables are extractable not only from the MODFLOW models, but are also available nationally from databases of water use (for example, Buchwald, 2009), well construction logs (for example, Bayless and others, 2017) and hydrography (for example, the U.S. Geological Survey National Hydrography Database, https://www.sciencebase.gov/catalog/ item/4f70aa9fe4b058caae3f8de5).

The candidate predictors listed in the first four $(A-D)$ parts of table 12 are each calculated in reference to the row, column, and layer occupied by an existing or seeded well. For example, the "depth of top of open interval below water table" is computed as the depth from the simulated water table at the row/column location of the well to the top of the layer occupied by the well (or, in the case of a multi-layer existing well, the top of the top layer occupied by the well). This predictor could be quantified for a well outside the model domain by using information in its well $\log$ (depth to top of casing, static water level) or a regional water-table map.

A number of other candidate predictors are linked to the hydrogeology in the steady-state capture zone around the well (for example, recharge, surface-water density, glacial transmissivity, shallow bedrock transmissivity). The capture zone of the well is delineated by the application of MODPATH to the MODFLOW models, but the shape and extent for an arbitrary well location is generally not available from any database outside the model domains. Therefore, a surrogate for capture zone must be employed to quantify these candidate predictors. The surrogate is referred to as "local area" (Feinstein and others, 2016). Since the shape and extent of the capture zone is assumed to be unknown, in its place a series of local areas are applied, each equivalent to a circle with a prescribed radius around the well of interest. For this study, the circle radii are set to $0.25 \mathrm{mi}, 0.5 \mathrm{mi}, 1 \mathrm{mi}, 1.5 \mathrm{mi}, 2.0 \mathrm{mi}, 2.5 \mathrm{mi}, 3.0 \mathrm{mi}$, $4 \mathrm{mi}, 5 \mathrm{mi}, 6 \mathrm{mi}, 7 \mathrm{mi}$, and $8 \mathrm{mi}$. The local-area predictors (table 12) are evaluated for each of 12 circles around the well of interest. The prospective metamodeling process can be used to determine which radii for which predictors are most important in explaining the groundwater age distribution of discharge at the existing and seeded wells. It is worth emphasizing that the capture zones around shallow wells rarely take the form of circles, usually tending to more elongated and 
Table 12. Candidate predictors for use with prospective metamodel of groundwater age of glacial well discharge.

[(r), indicates predictor is function of radial distance from glacial well]

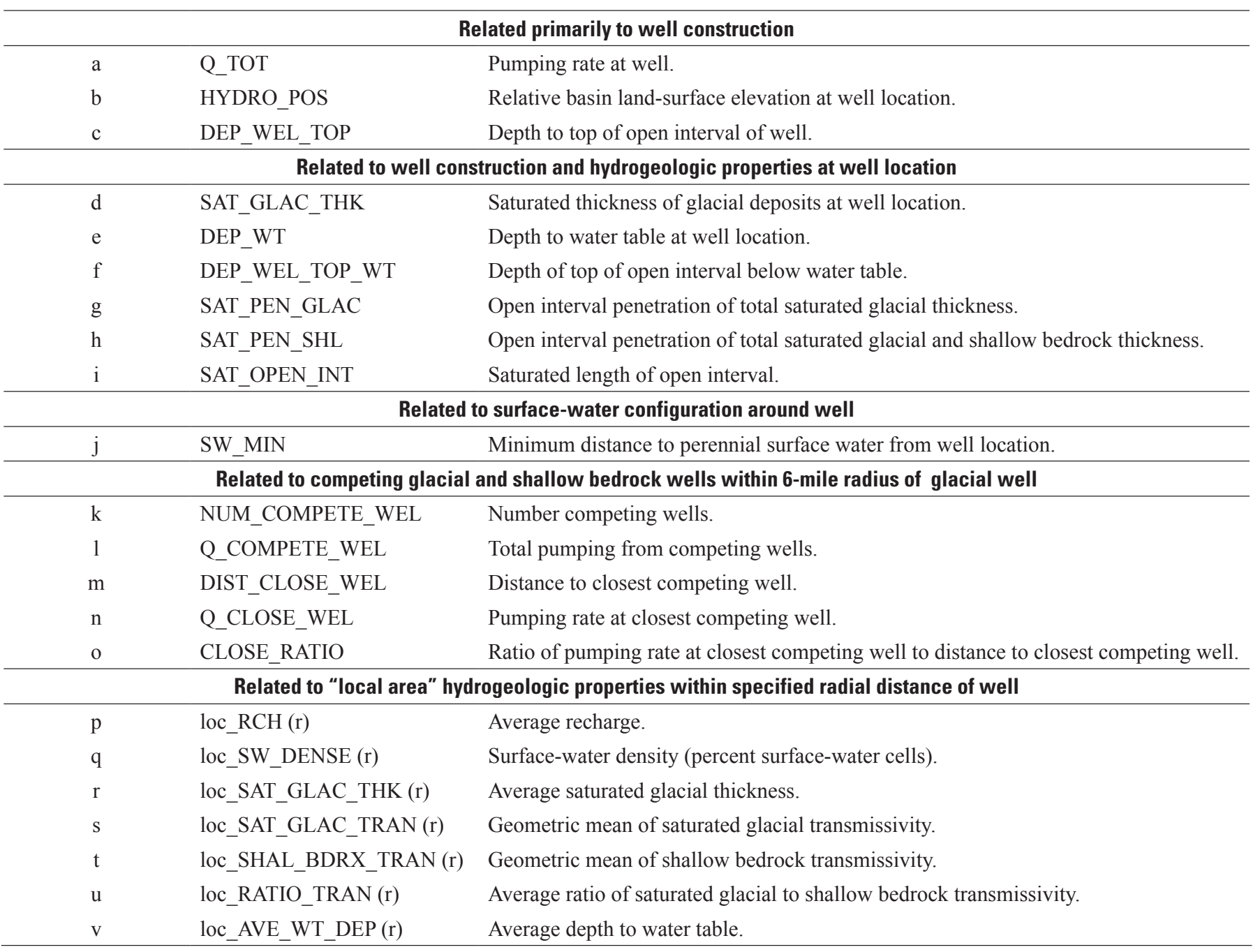

asymmetric forms. However, in the absence of knowledge about the shape and orientation of the capture zone, the use of concentric circles to sample the local area is a simple, if crude, substitute.

The local-area recharge is computed as the arithmetic average of the recharge to an inset model within the prescribed circle centered on an existing or seeded well. The surfacewater density in the local area is computed by summing all the active surface-water cells (that is SFR cells simulated to have base flow and DRN cells with water-body levels below the simulated water table) and dividing by the total number of cells within the prescribed circle radius. The local-area average glacial thickness is computed as the arithmetic average of the saturated glacial thickness (depth from water table to top of bedrock) within the circle radius.

The local-area glacial transmissivity is computed as the geometric mean of the saturated glacial transmissivity within the prescribed circle radius. The local-area bedrock transmissivity is computed as the geometric mean of the transmissivity of the saturated bedrock within the circle from the top of bedrock to the first confining unit (the "shallow" part of the bedrock). A confining unit is defined as a model layer with a vertical resistance (the ratio of thickness to vertical hydraulic conductivity) greater than 50,000 days. For example, a model bedrock cell that is 50 - $\mathrm{ft}$ thick with a vertical conductivity less than $0.001 \mathrm{ft} / \mathrm{d}$ would qualify as a local confining unit. The ratio of the local-area glacial transmissivity to the local-area shallow bedrock transmissivity is also a candidate predictor. Finally, the local-area depth to water table is computed as the arithmetic average of the depth from the top of layer 1 to the simulated water table within the prescribed circle.

There are several recharge, well log, and transmissivity datasets that could populate the candidate local-area predictors outside the inset model domains (for example, Wolock, 2003; 
Bayless and others, 2017). Transmissivity was chosen as a hydrogeologic predictor because it is judged easier to estimate and map than average glacial or shallow bedrock hydraulic conductivity over large areas.

In all, there are 99 candidate predictors judged by the authors to be promising predictors of groundwater age. A condition for choosing each predictor is that it is quantified across the inset models as part of this study and that data sources are available to map it outside the model domains in other parts of the glacial system on the basis of existing well-log databases or GIS databases containing landscape and aquifer variables. The predictors are grouped into 22 categories (table 12) of which 15 are not area dependent and 7 were evaluated for 12 local-area circles. From the standpoint of the prospective metamodel, the candidate predictors from the five inset models were pooled in an effort to explain the simulated age distribution calculated for existing and seeded glacial wells. A single table of the 99 candidate predictors for each of the 8,222 instances (398 existing and 7,824 seeded wells) has been assembled and archived. The table is available through the data release for the project - see Haserodt and others, 2018.

To provide insight into the statistical behavior of predictors across the five inset models, 22 graphs are included in this report that approximate the cumulative density function (cumulative frequency) for all 15 of the non-area dependent variables and the cumulative density function for the 7 localarea predictors, assuming a circle radius of $1 \mathrm{mi}$ (figs. $35 A-V$ ). For each graph, the horizontal axis represents the range of candidate predictor values across all five inset models pooled together. The relation of a point on a curve to the vertical axis represents the likelihood that a given predictor value at any well location is less than the value on the horizontal axis. A line that is roughly straight on the graph indicates a near-uniform distribution across the predictor range (see, for example, fig. $35 T$ showing local-area shallow bedrock transmissivity); a line that is steep at the low end and flat at the high end (concave down) indicates that most of the predictor values fall at the low end of its range (see, for example, fig. $35 E$ showing the simulated depth to water table at the well location); a line that is flat at the low end and steep at the high end (concave up) indicates that most of the predictor values fall at the high end of the range (see, for example, fig. $35 \mathrm{H}$ showing well open interval as fraction of total saturated glacial thickness). The minimum range value is almost always zero across the predictor plots. Two exceptions are the graphs showing depth to tops of open intervals of glacial wells (fig. 35C) and depths from the water table to top of glacial wells (fig. 35E). For about one-half of the existing and seeded wells, these predictor depths are zero because the wells are open to layer 1 (fig. $35 \mathrm{C}$ ) or because the water table is in the layer hosting the well (fig. 35F).

\section{Age Metrics Simulated by MODPATH}

The outcomes of interest that are a function of the candidate predictors in the prospective metamodels are the four age metrics (table 11) evaluated for the glacial well locations in the target basins of the five inset models. The MODPATH calculation and results have been presented in previous report sections. The cumulative density functions for the four age metrics for all the existing and seeded wells in all the five inset models are shown in figures $36 A-D$. The simulated median value for the fraction of young water in the glacial well discharge (less than 65 years) across the target basins is 0.9 , but about 20 percent of the wells have as much old water as young water (fig. 36A). The median age of discharge for about 90 percent of the wells falls between 3 and 100 years, with an expected median age value across all simulated wells of about 19 years (fig. 36D).

A statistical summary of the predictors and age metrics are compiled in table 13. The distributions across all five inset model basins are described in terms of average, median, maximum, and selected percentile values. In table 13, statistics for the 398 existing glacial wells (some of which penetrate multiple glacial layers) and those of the 7,824 seeded wells (all of which penetrate only one glacial layer) are listed separately and in total. In general, the statistical values (for example, the median) are similar for the existing and seeded wells. In particular, the age metric statistics are similar. There are large differences for some of the predictors - notably, in the case of saturated glacial thickness (d), pumping in competing shallow wells (l), and local saturated glacial transmissivity (s). For these predictors the distribution values are higher for the existing wells than for the seeded wells because the existing wells tend to be grouped in areas where the glacial aquifer is most productive. This limited bias should not interfere with the ability of a prospective metamodel to determine the general correlation structure between predictors and age metrics. 


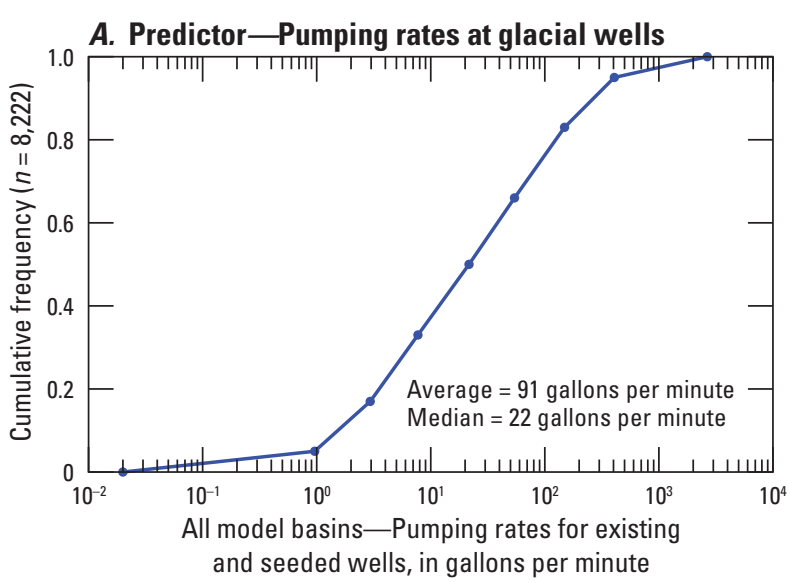

C. Predictor-Depth to tops of open intervals of glacial wells

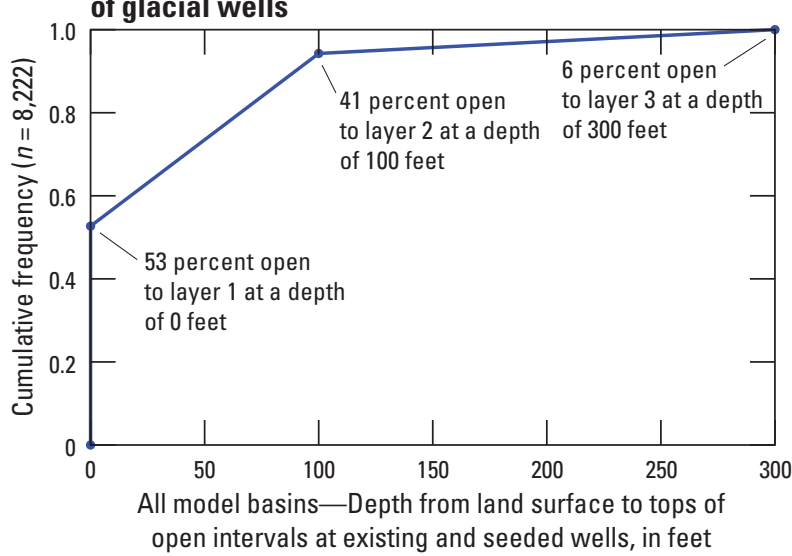

B. Predictor-Relative basin land-surface elevation

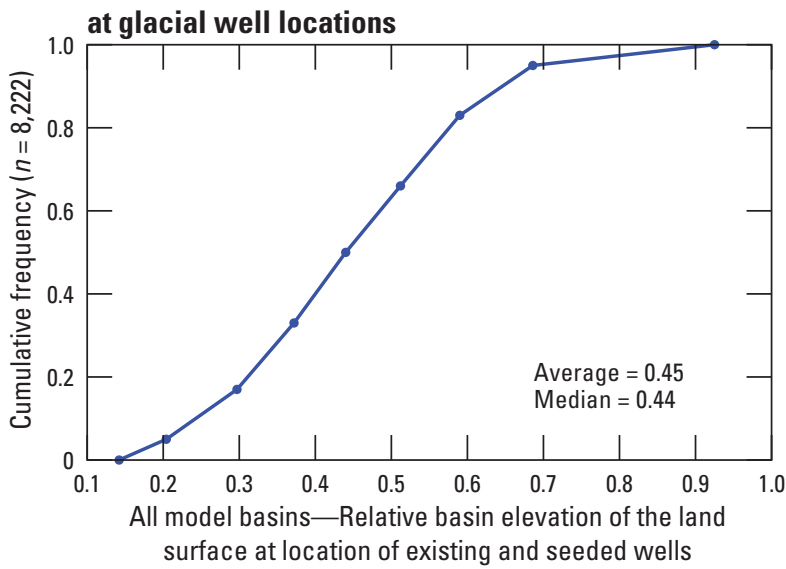

D. Predictor-Simulated saturated thickness of glacial deposits at glacial well locations

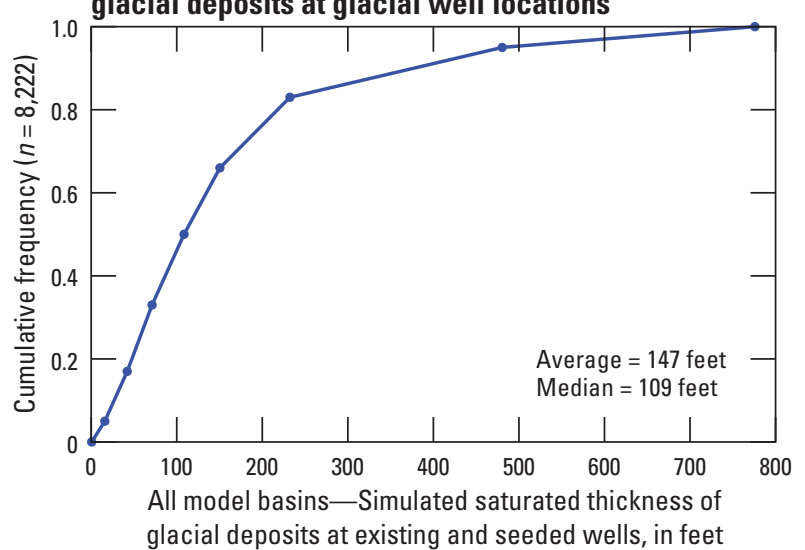

Figure 35. Cumulative distribution plots for candidate predictors across all inset model target 8-digit hydrologic unit code (HUC8) basins. $A$, pumping rates at glacial wells; $B$, relative basin land-surface elevation at glacial well locations; $C$, depth to tops of open intervals of glacial wells; $D$, simulated saturated thickness of glacial deposits at glacial well locations; $E$, depth to simulated water table at glacial well locations; $F$, depth of top of open interval of glacial well below simulated water-table elevation; $G$, saturated open interval at glacial wells; $H$, well open interval as fraction of total saturated glacial thickness; $I$, well open interval as fraction of total saturated glacial and shallow bedrock thickness; $J$, minimum distance to active surface-water body from glacial well location; $K$, number of competing glacial and shallow bedrock wells within a 6 -mile radius of selected well; $L$, total discharge from competing glacial and shallow bedrock wells; $M$, distance to closest competing glacial or shallow bedrock well; $N$, pumping rate at closest competing glacial or shallow bedrock well; 0 , ratio of pumping rate (gal/min) at closest competing well to distance (miles) of closest competing well; $P$, mean recharge within a 1-mile radius of glacial well; $Q$, surfacewater density as percentage of cells occupied by active surface water within a 1-mile radius of glacial well; $R$, mean simulated saturated glacial thickness within a 1-mile radius of glacial well; $S$, geometric mean of saturated glacial transmissivity within a 1-mile radius of glacial well; $T$, geometric mean of shallow bedrock transmissivity within a 1-mile radius of glacial well; $U$, mean ratio of saturated glacial to shallow bedrock transmissivity within a 1-mile radius of glacial well; and $V$, mean depth to water table within a 1-mile radius of glacial well. 

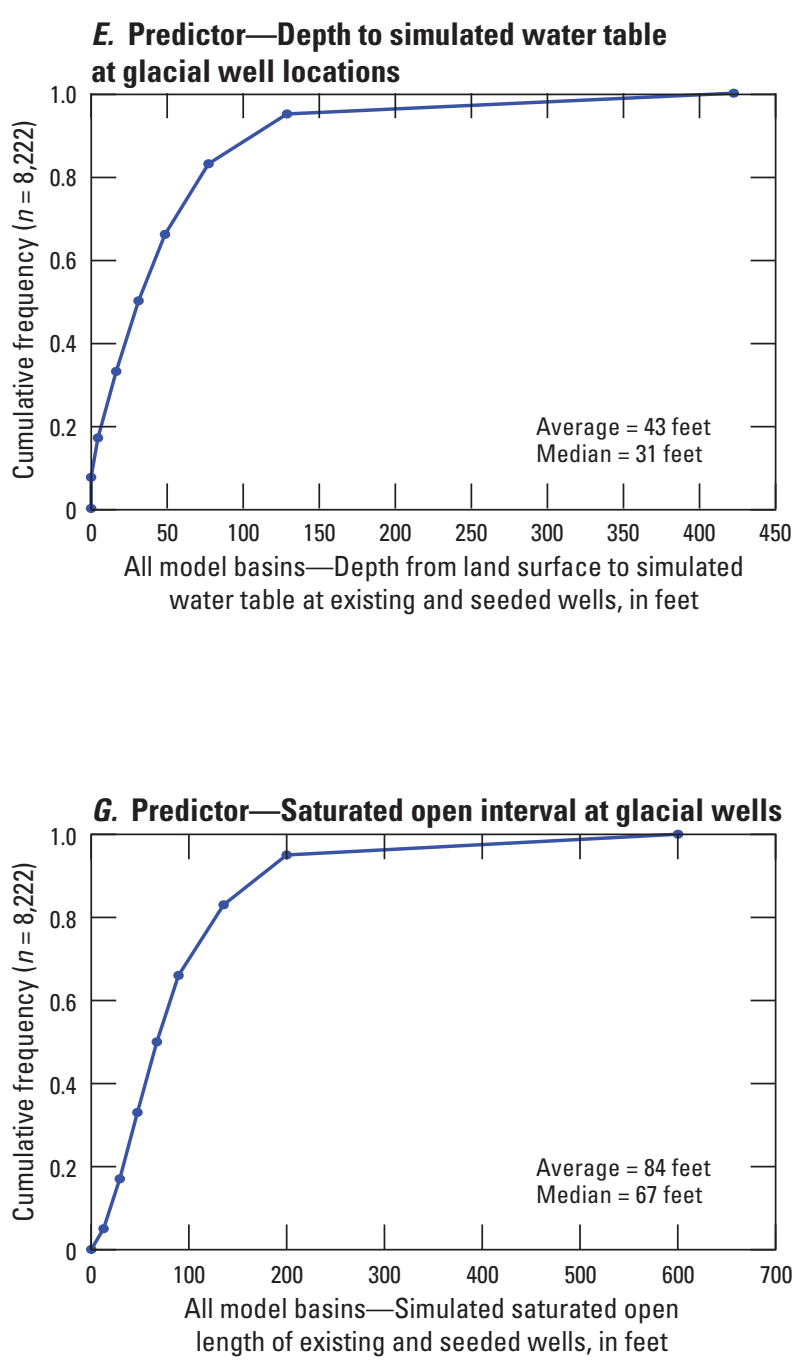
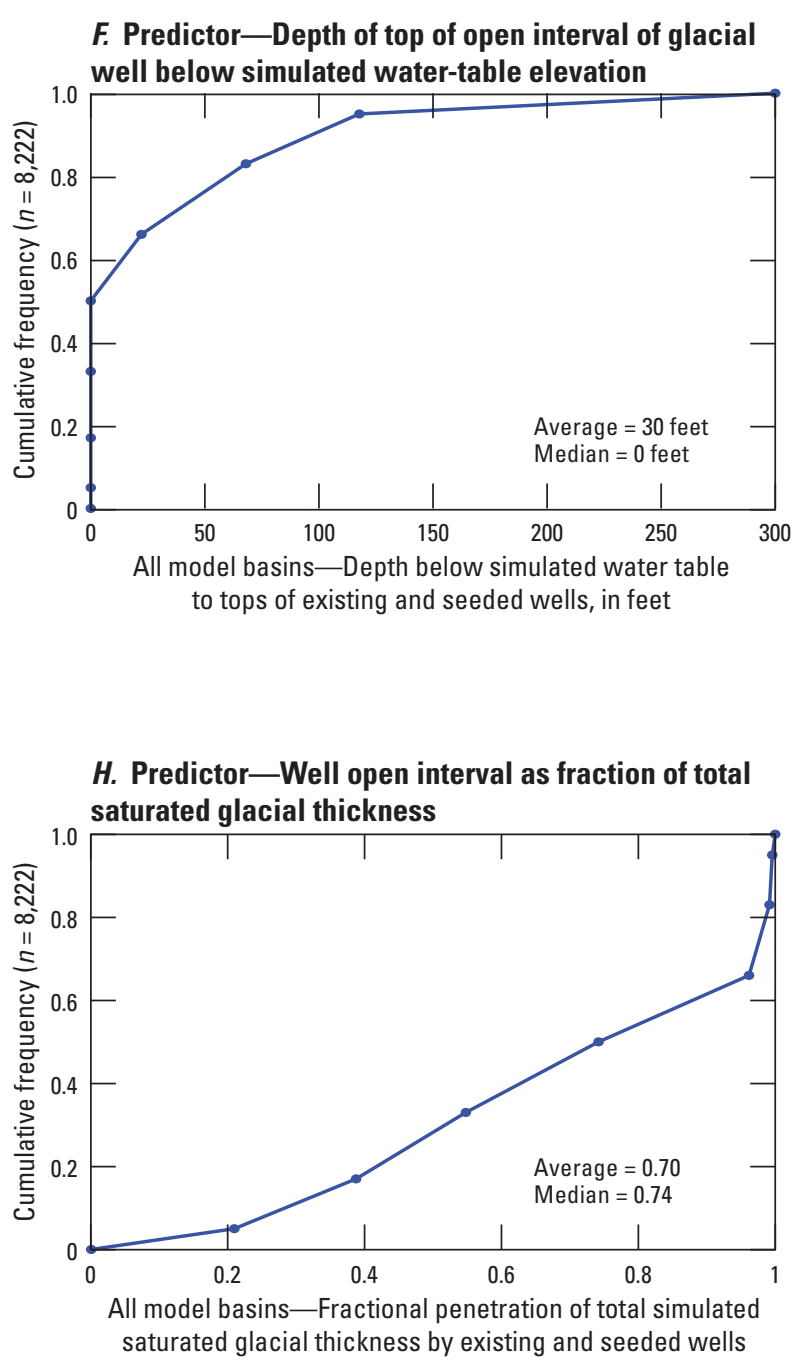

Figure 35. Cumulative distribution plots for candidate predictors across all inset model target 8-digit hydrologic unit code (HUC8) basins. $A$, pumping rates at glacial wells; $B$, relative basin land-surface elevation at glacial well locations; $C$, depth to tops of open intervals of glacial wells; $D$, simulated saturated thickness of glacial deposits at glacial well locations; $E$, depth to simulated water table at glacial well locations; $F$, depth of top of open interval of glacial well below simulated water-table elevation; $G$, saturated open interval at glacial wells; $H$, well open interval as fraction of total saturated glacial thickness; $I$, well open interval as fraction of total saturated glacial and shallow bedrock thickness; $J$, minimum distance to active surface-water body from glacial well location; $K$, number of competing glacial and shallow bedrock wells within a 6 -mile radius of selected well; $L$, total discharge from competing glacial and shallow bedrock wells; $M$, distance to closest competing glacial or shallow bedrock well; $N$, pumping rate at closest competing glacial or shallow bedrock well; $O$, ratio of pumping rate (gal/min) at closest competing well to distance (miles) of closest competing well; $P$, mean recharge within a 1-mile radius of glacial well; $Q$, surfacewater density as percentage of cells occupied by active surface water within a 1-mile radius of glacial well; $R$, mean simulated saturated glacial thickness within a 1 -mile radius of glacial well; $S$, geometric mean of saturated glacial transmissivity within a 1-mile radius of glacial well; $T$, geometric mean of shallow bedrock transmissivity within a 1-mile radius of glacial well; $U$, mean ratio of saturated glacial to shallow bedrock transmissivity within a 1-mile radius of glacial well; and $V$, mean depth to water table within a 1-mile radius of glacial well.-Continued 


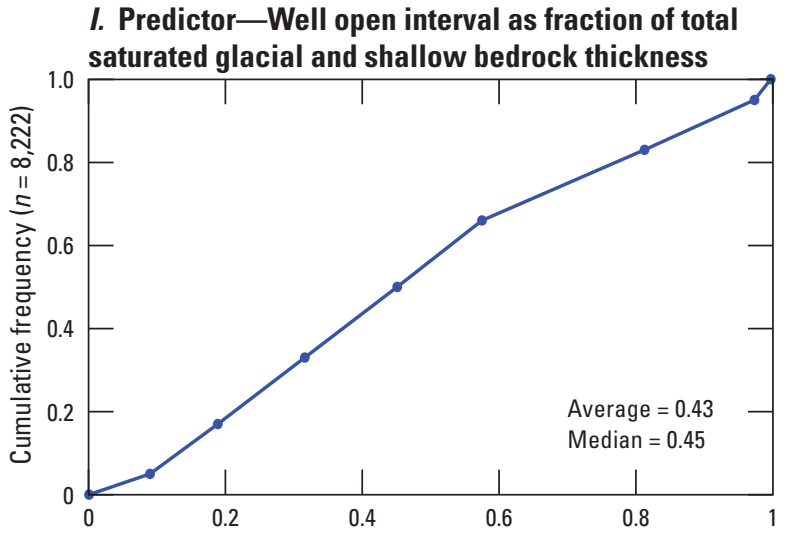

All model basins-Fractional penetration of total simulated saturated glacial and shallow bedrock thickness by existing and seeded wells
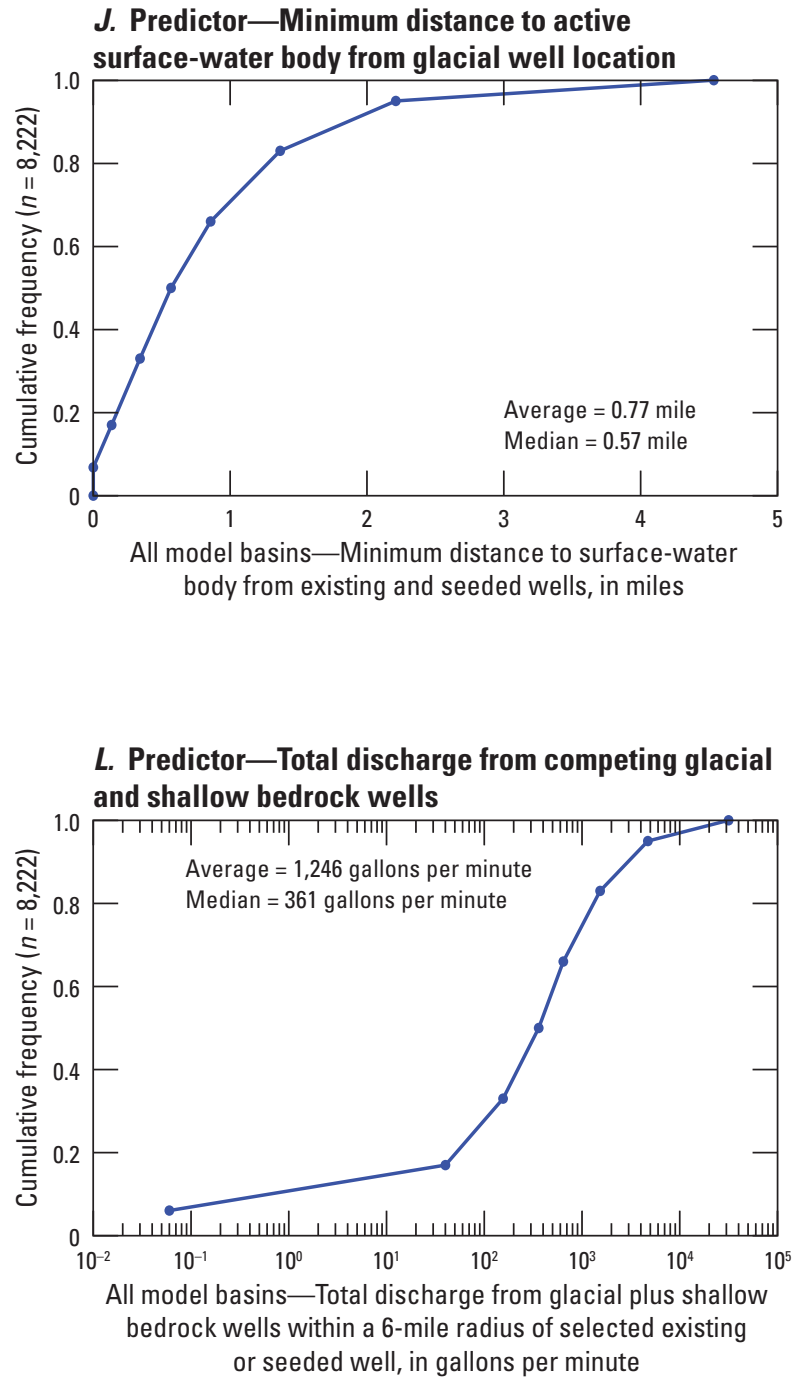

Figure 35. Cumulative distribution plots for candidate predictors across all inset model target 8-digit hydrologic unit code (HUC8) basins. A, pumping rates at glacial wells; $B$, relative basin land-surface elevation at glacial well locations; $C$, depth to tops of open intervals of glacial wells; $D$, simulated saturated thickness of glacial deposits at glacial well locations; $E$, depth to simulated water table at glacial well locations; $F$, depth of top of open interval of glacial well below simulated water-table elevation; $G$, saturated open interval at glacial wells; $H$, well open interval as fraction of total saturated glacial thickness; $I$, well open interval as fraction of total saturated glacial and shallow bedrock thickness; $J$, minimum distance to active surface-water body from glacial well location; $K$, number of competing glacial and shallow bedrock wells within a 6 -mile radius of selected well; $L$, total discharge from competing glacial and shallow bedrock wells; $M$, distance to closest competing glacial or shallow bedrock well; $N$, pumping rate at closest competing glacial or shallow bedrock well; 0 , ratio of pumping rate ( $\mathrm{gal} / \mathrm{min}$ ) at closest competing well to distance (miles) of closest competing well; $P$, mean recharge within a 1-mile radius of glacial well; $Q$, surfacewater density as percentage of cells occupied by active surface water within a 1-mile radius of glacial well; $R$, mean simulated saturated glacial thickness within a 1-mile radius of glacial well; $S$, geometric mean of saturated glacial transmissivity within a 1-mile radius of glacial well; $T$, geometric mean of shallow bedrock transmissivity within a 1-mile radius of glacial well; $U$, mean ratio of saturated glacial to shallow bedrock transmissivity within a 1-mile radius of glacial well; and $V$, mean depth to water table within a 1-mile radius of glacial well.-Continued 

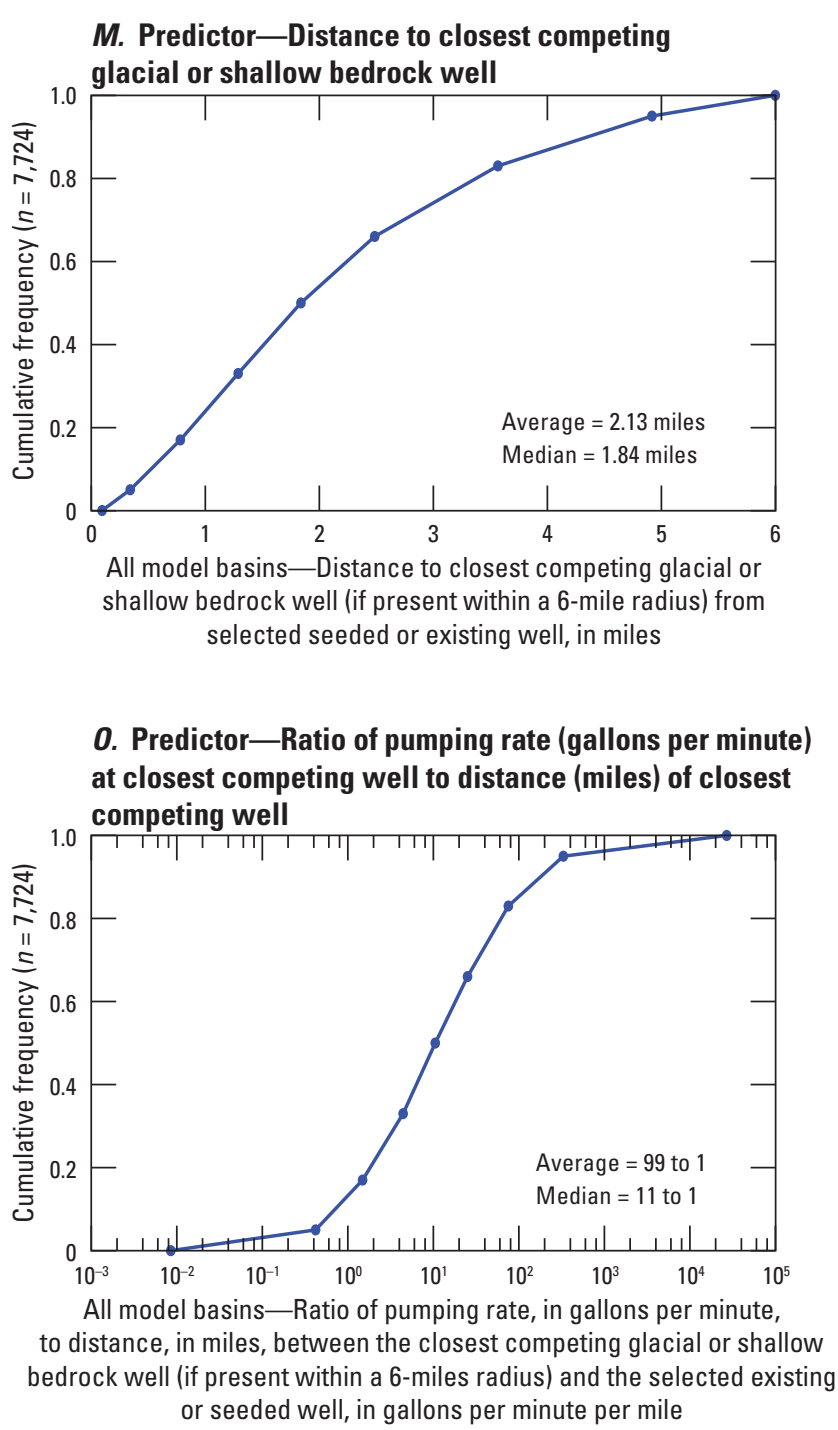
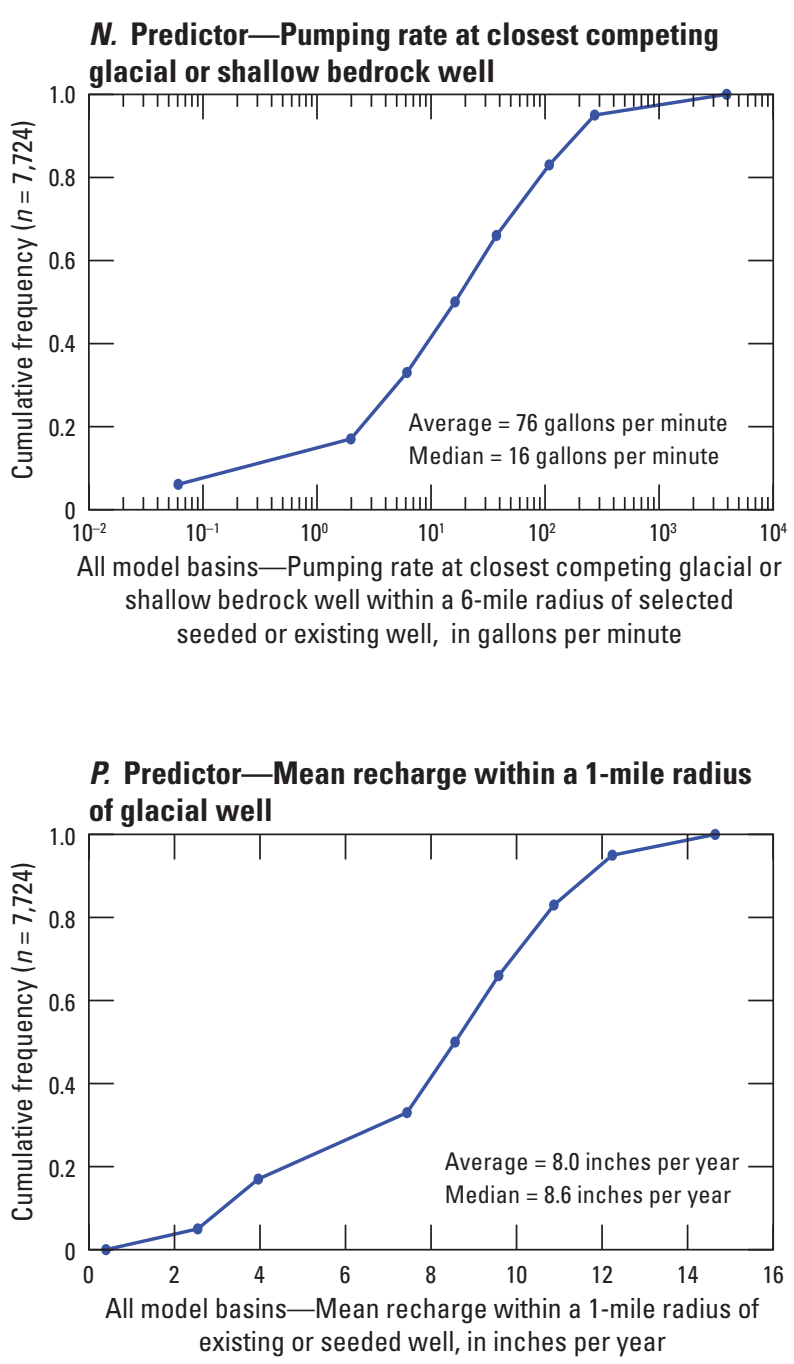

Figure 35. Cumulative distribution plots for candidate predictors across all inset model target 8-digit hydrologic unit code (HUC8) basins. $A$, pumping rates at glacial wells; $B$, relative basin land-surface elevation at glacial well locations; $C$, depth to tops of open intervals of glacial wells; $D$, simulated saturated thickness of glacial deposits at glacial well locations; $E$, depth to simulated water table at glacial well locations; $F$, depth of top of open interval of glacial well below simulated water-table elevation; $G$, saturated open interval at glacial wells; $H$, well open interval as fraction of total saturated glacial thickness; $I$, well open interval as fraction of total saturated glacial and shallow bedrock thickness; $J$, minimum distance to active surface-water body from glacial well location; $K$, number of competing glacial and shallow bedrock wells within a 6 -mile radius of selected well; $L$, total discharge from competing glacial and shallow bedrock wells; $M$, distance to closest competing glacial or shallow bedrock well; $N$, pumping rate at closest competing glacial or shallow bedrock well; 0 , ratio of pumping rate (gal $/ \mathrm{min})$ at closest competing well to distance (miles) of closest competing well; $P$, mean recharge within a 1-mile radius of glacial well; $Q$, surfacewater density as percentage of cells occupied by active surface water within a 1-mile radius of glacial well; $R$, mean simulated saturated glacial thickness within a 1-mile radius of glacial well; $\mathcal{S}$, geometric mean of saturated glacial transmissivity within a 1 -mile radius of glacial well; $T$, geometric mean of shallow bedrock transmissivity within a 1-mile radius of glacial well; $U$, mean ratio of saturated glacial to shallow bedrock transmissivity within a 1-mile radius of glacial well; and $V$, mean depth to water table within a 1-mile radius of glacial well.-Continued 


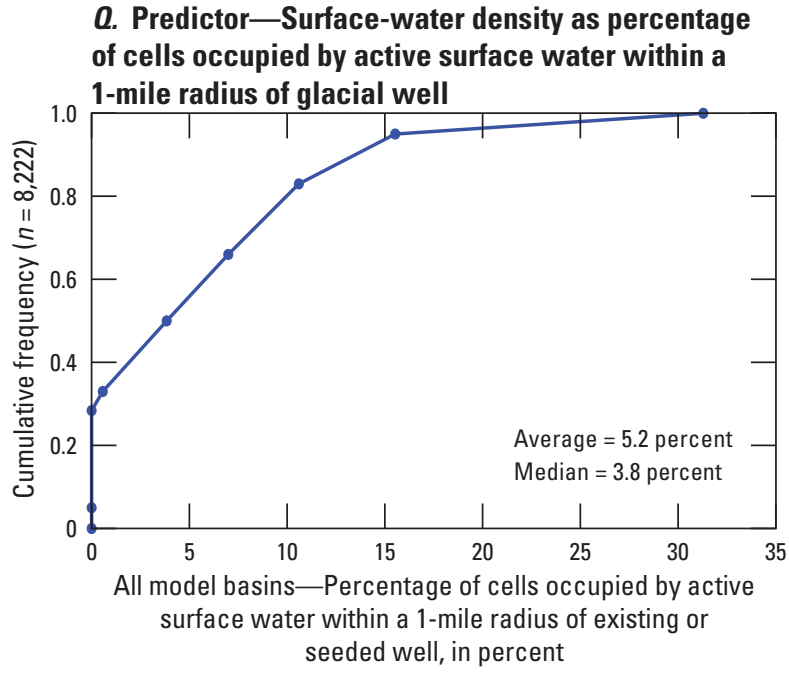

S. Predictor-Geometric mean of saturated glacial

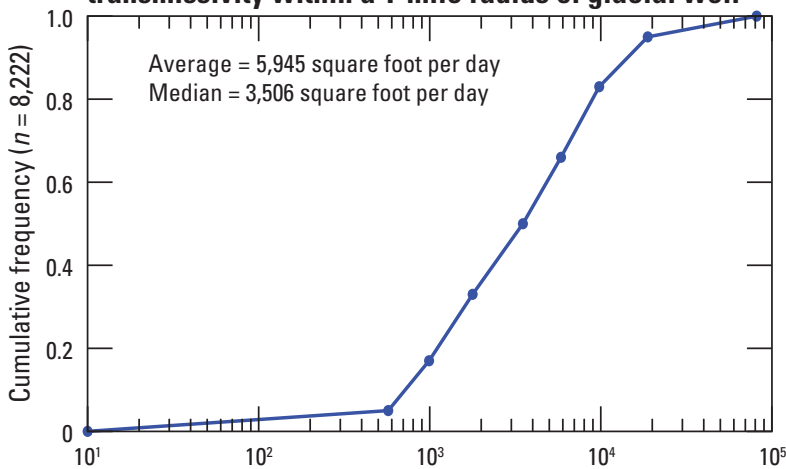

All model basins-Geometric mean of saturated glacial transmissivity within a 1-mile radius of existing or seeded well, in square feet per day transmissivity within a 1-mile radius of glacial well
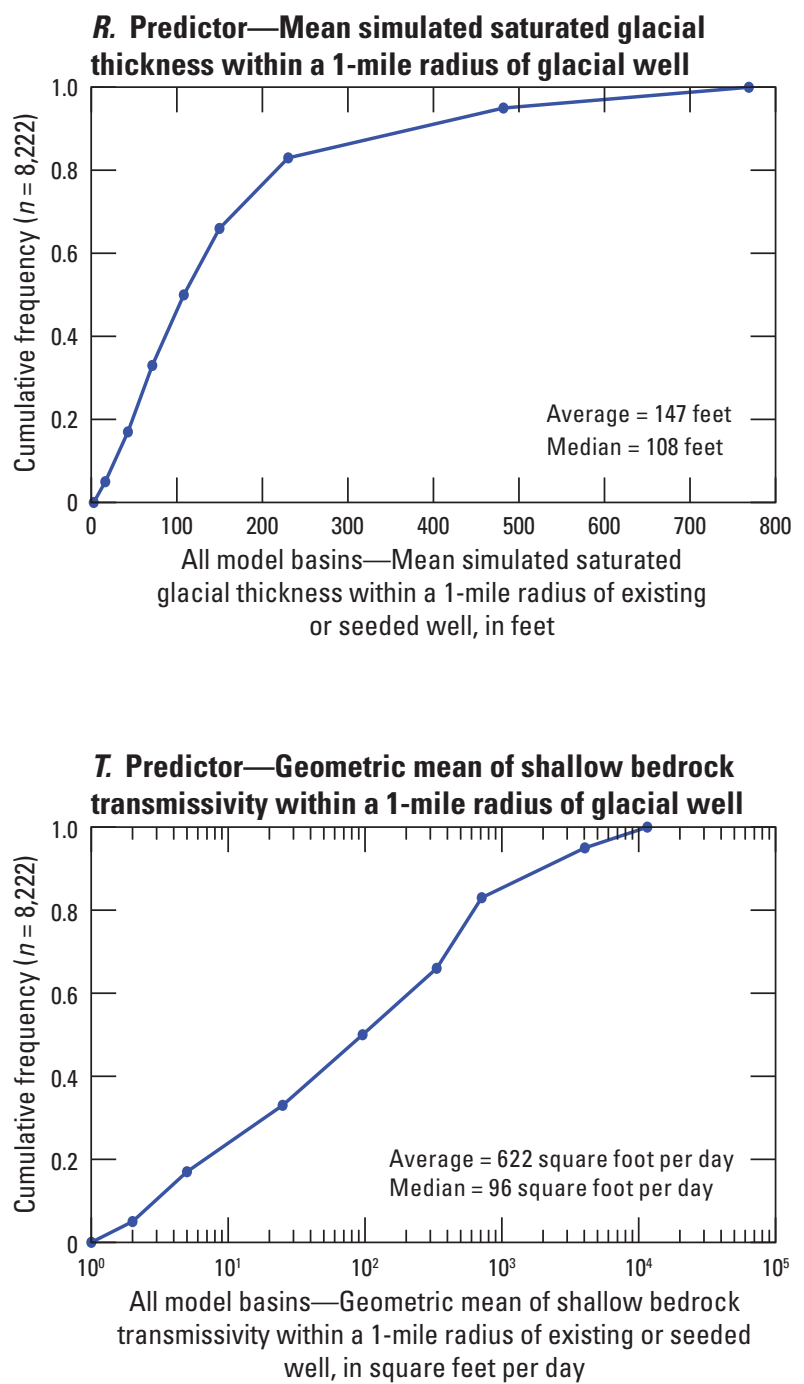

Figure 35. Cumulative distribution plots for candidate predictors across all inset model target 8-digit hydrologic unit code (HUC8) basins. $A$, pumping rates at glacial wells; $B$, relative basin land-surface elevation at glacial well locations; $C$, depth to tops of open intervals of glacial wells; $D$, simulated saturated thickness of glacial deposits at glacial well locations; $E$, depth to simulated water table at glacial well locations; $F$, depth of top of open interval of glacial well below simulated water-table elevation; $G$, saturated open interval at glacial wells; $H$, well open interval as fraction of total saturated glacial thickness; $I$, well open interval as fraction of total saturated glacial and shallow bedrock thickness; $J$, minimum distance to active surface-water body from glacial well location; $K$, number of competing glacial and shallow bedrock wells within a 6 -mile radius of selected well; $L$, total discharge from competing glacial and shallow bedrock wells; $M$, distance to closest competing glacial or shallow bedrock well; $N$, pumping rate at closest competing glacial or shallow bedrock well; 0 , ratio of pumping rate (gal $/ \mathrm{min}$ ) at closest competing well to distance (miles) of closest competing well; $P$, mean recharge within a 1-mile radius of glacial well; $Q$, surfacewater density as percentage of cells occupied by active surface water within a 1-mile radius of glacial well; $R$, mean simulated saturated glacial thickness within a 1-mile radius of glacial well; $S$, geometric mean of saturated glacial transmissivity within a 1-mile radius of glacial well; $T$, geometric mean of shallow bedrock transmissivity within a 1-mile radius of glacial well; $U$, mean ratio of saturated glacial to shallow bedrock transmissivity within a 1-mile radius of glacial well; and $V$, mean depth to water table within a 1-mile radius of glacial well._-Continued 


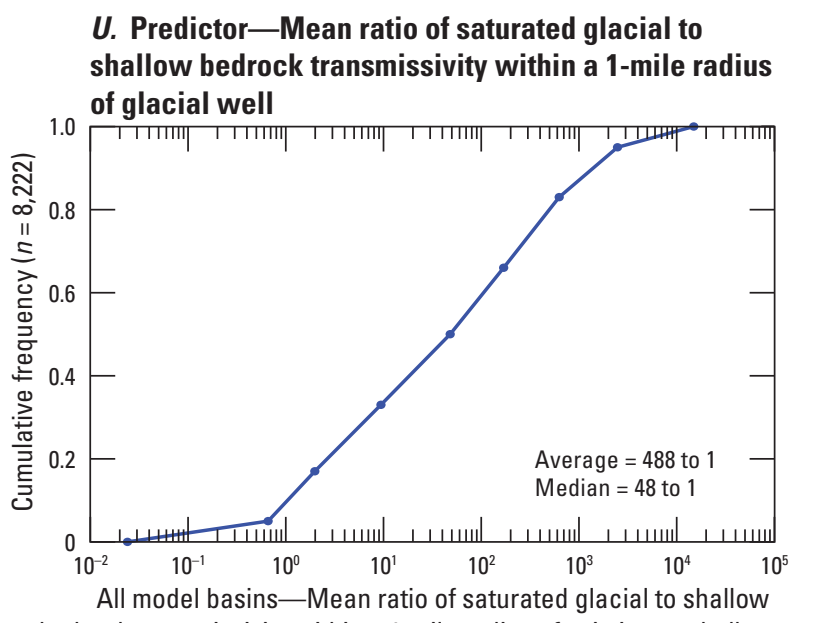

bedrock transmissivity within a 1-mile radius of existing or shallow well

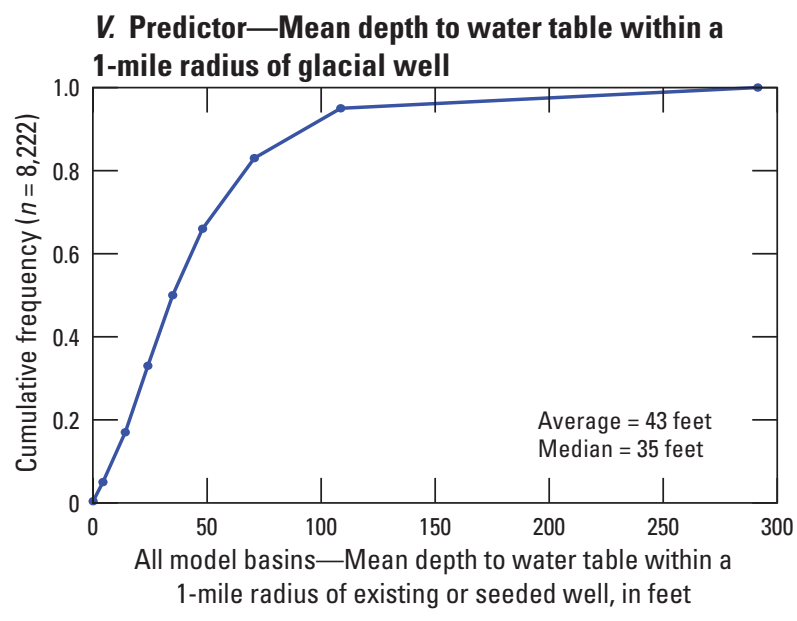

Figure 35. Cumulative distribution plots for candidate predictors across all inset model target 8-digit hydrologic unit code (HUC8) basins. $A$, pumping rates at glacial wells; $B$, relative basin land-surface elevation at glacial well locations; $C$, depth to tops of open intervals of glacial wells; $D$, simulated saturated thickness of glacial deposits at glacial well locations; $E$, depth to simulated water table at glacial well locations; $F$, depth of top of open interval of glacial well below simulated water-table elevation; $G$, saturated open interval at glacial wells; $H$, well open interval as fraction of total saturated glacial thickness; $I$, well open interval as fraction of total saturated glacial and shallow bedrock thickness; $J$, minimum distance to active surface-water body from glacial well location; $K$, number of competing glacial and shallow bedrock wells within a 6 -mile radius of selected well; $L$, total discharge from competing glacial and shallow bedrock wells; $M$, distance to closest competing glacial or shallow bedrock well; $N$, pumping rate at closest competing glacial or shallow bedrock well; $O$, ratio of pumping rate (gal/min) at closest competing well to distance (miles) of closest competing well; $P$, mean recharge within a 1-mile radius of glacial well; $Q$, surfacewater density as percentage of cells occupied by active surface water within a 1-mile radius of glacial well; $R$, mean simulated saturated glacial thickness within a 1-mile radius of glacial well; $S$, geometric mean of saturated glacial transmissivity within a 1 -mile radius of glacial well; $T$, geometric mean of shallow bedrock transmissivity within a 1-mile radius of glacial well; $U$, mean ratio of saturated glacial to shallow bedrock transmissivity within a 1-mile radius of glacial well; and $V$, mean depth to water table within a 1-mile radius of glacial well._-Continued 

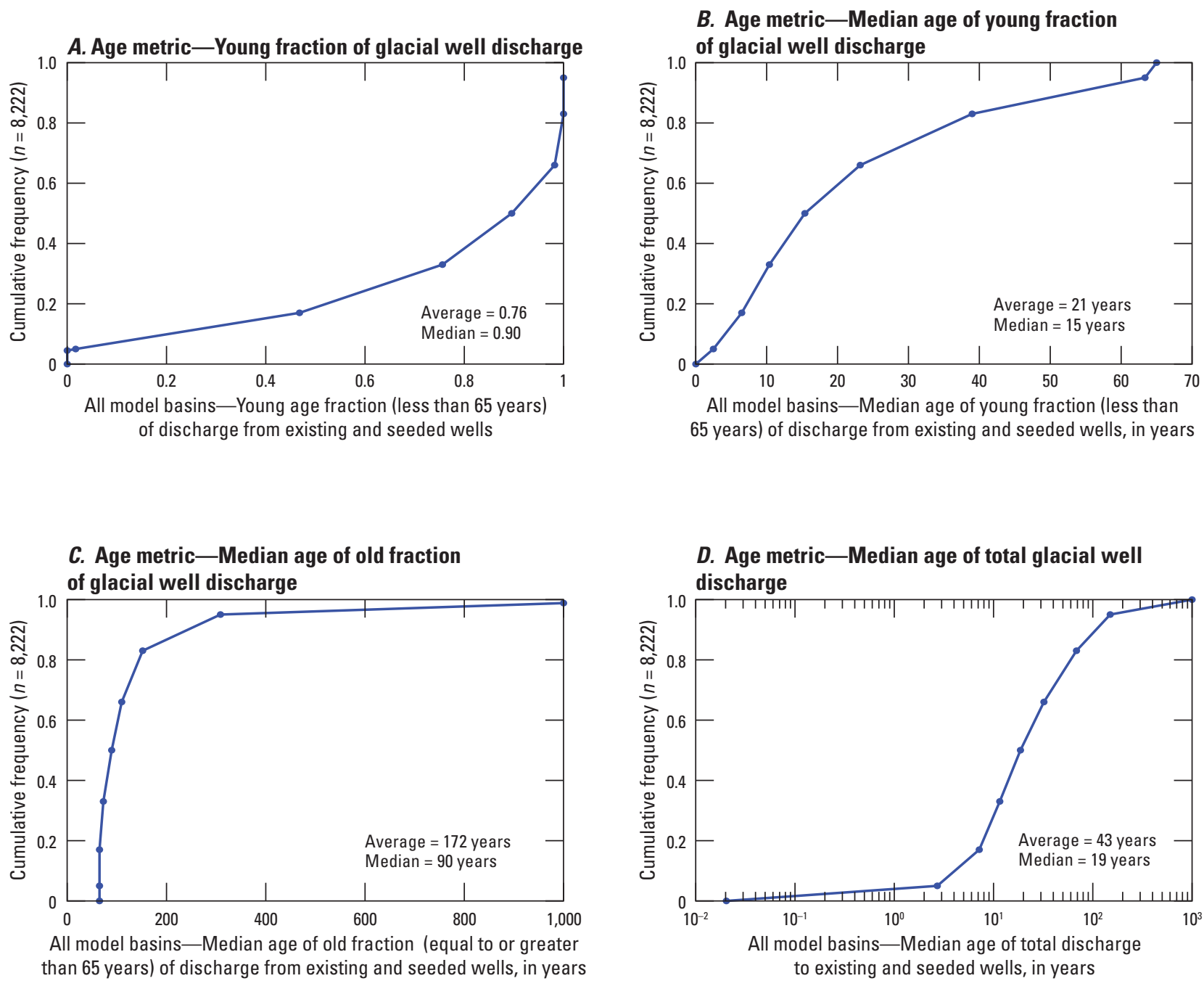

Figure 36. Cumulative distribution plots for age metrics across all inset model target 8-digit hydrologic unit code (HUC8) basins. Curves consist of straight line segments between values corresponding respectively to minimum value, 5th percentile, 25th percentile, median, 75th percentile, 95th percentile, and maximum value. $A$, young fraction of glacial well discharge; $B$, median age of young fraction of glacial well discharge; $C$, median age of old fraction of glacial well discharge; and $D$, median age of total glacial well discharge. 
8
8

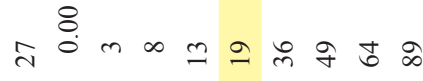
ป

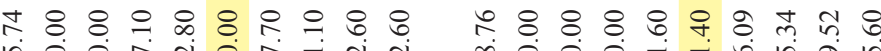

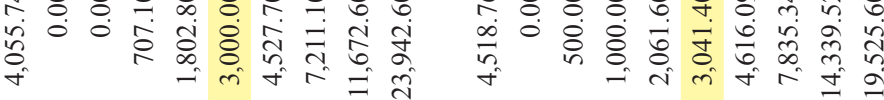

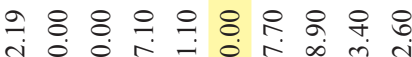
感

- 容忌高总

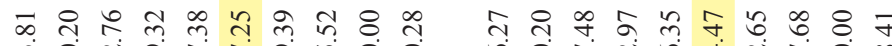
fं

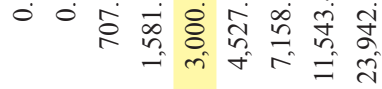

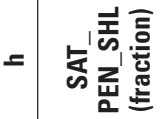

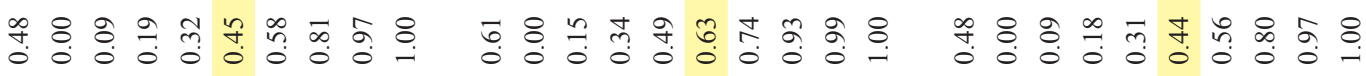

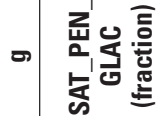

융 \&

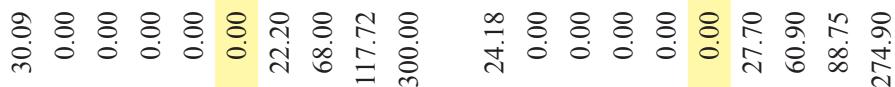

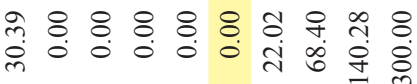

- 㧽占总

๘ \& \&

กิ 8 ก กิ - 窇容总

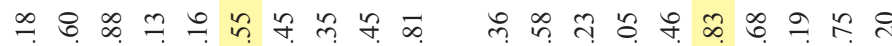

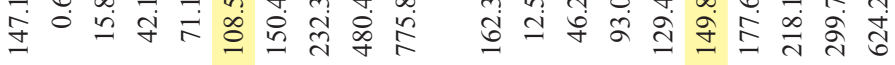

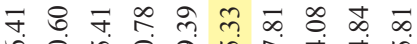
(1)

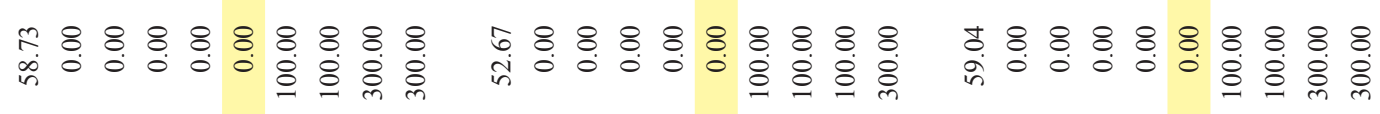

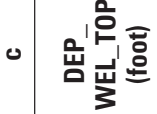

-

告 竞

年 $\begin{aligned} & \pm \\ & 0\end{aligned}$

๙ 占高

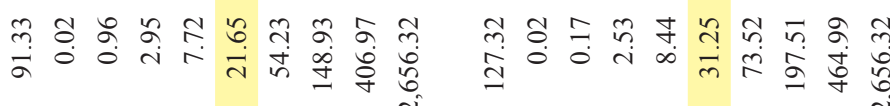

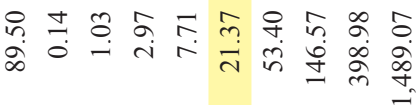

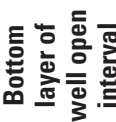

$\stackrel{\leftrightarrow}{\leftrightarrow}$

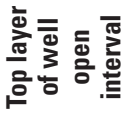

$\stackrel{n}{\rightarrow}$

$--i-4 \ln m$

$\stackrel{\sqrt[n]{-}}{-}$

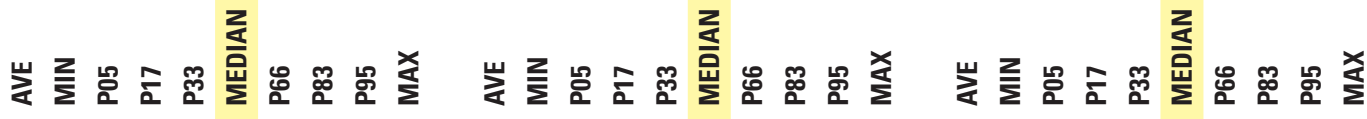
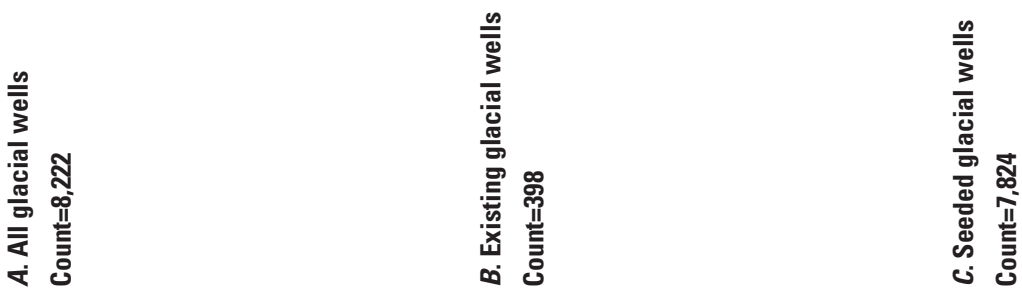


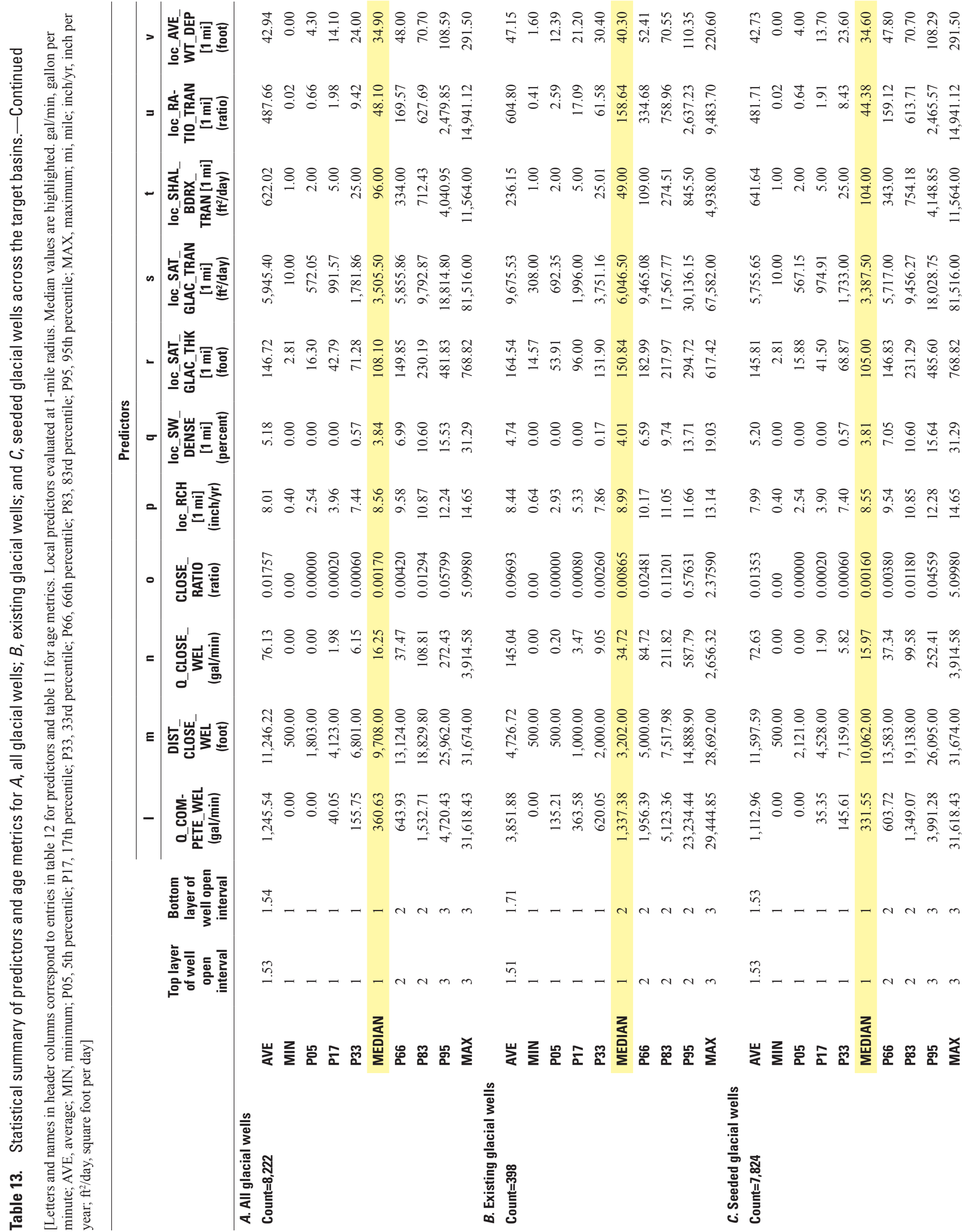




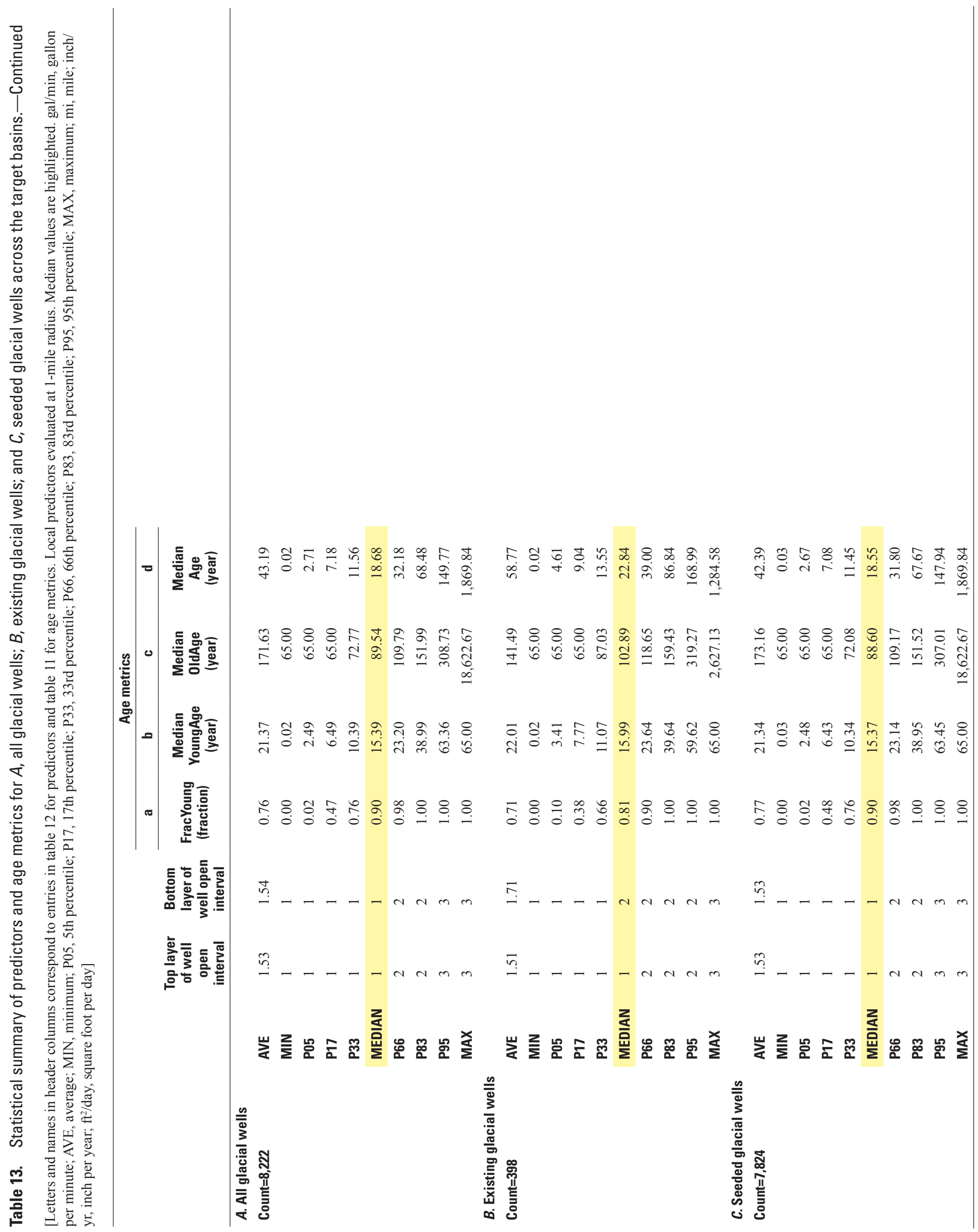




\section{Prospective Statistical Modeling}

The five MODFLOW inset models were constructed and applied to support anticipated statistical modeling of the simulated age metrics for discharge to glacial wells generated by MODPATH. Statistical modeling techniques that could be used to generate age predictions are outlined in Fienen and others (2016). That study focused on metamodels designed to emulate the stream contribution to groundwater pumped from shallow wells (with emphasis on the depletion of headwater streams in response to pumping). The metamodels they present were trained on a MODFLOW model (Feinstein and others, 2016), which supplies the candidate predictors (notably minimum distance to surface water and surface-water density) and the outcome to be explained (percent of well discharge contributed by diversion and inducement from local streams and water bodies). Three statistical techniques were tested in the Fienen and others (2016) study—Bayesian Network, Artificial Neural Networks, and Gradient Boosted Regression Tree.

All the tested statistical techniques have a common process that, first, depends on scientific judgment of cause and effect for selected candidate predictors and, second, relies on the statistical structure delineated by the metamodeling technique to link the candidate predictors to an outcome. In effect, the metamodel ranks the importance of the predictors and assigns them explanatory weights that take account of the correlation and sensitivity structure among the predictors in reference to a specific outcome. A similar process is anticipated for emulating the MODFLOW and MODPATH simulations of age in glacial well discharge. The candidate predictors that would inform the metamodeling are listed in table 12 . The four outcomes that the metamodeling would predict are listed in table 11. The anticipated predictions of the metamodels are, of course, without value until subjected to multiple statistical tests of explanatory power, some of which are detailed in Fienen and others (2016). If the metamodels are judged sufficiently powerful, there is the possibility that the metamodels could be applied outside the training domain (that is, beyond the extent of the LMB model). This final step depends on the ability to map predictors over the training area and the availability of tests to demonstrate that the statistical structures inherent in the metamodels are valid outside the training area (Feinstein and others, 2017).

\section{Summary and Conclusions}

A study was conducted to extract and modify five inset models from a regional model of Lake Michigan Basin (LMB). The five inset models were used to determine appropriate predictors of the age of groundwater pumped from existing and hypothetical (seeded) wells completed in glacial deposits. The development of inset flow models and predictor variables is a crucial and difficult step in the metamodeling process aimed at predicting the groundwater age of shallow well water. Because of the complexity of the effort, this entire report is devoted to documentation of work that is preliminary to future statistical modeling.

The development of five MODFLOW inset models extracted from the LMB regional model is described in this report. Application of the inset models using the particle-tracking code MODPATH to simulate the groundwater age distribution of discharge to wells pumping from glacial deposits also is described. The LMB model incorporates a large area in the upper Midwest that has diverse glacial settings (Feinstein and others, 2010). For these reasons it is a good starting point for sampling hydrogeologic conditions that affect the groundwater age in shallow well discharge. However, the 5,000- by 5,000 -ft grid spacing of this regional model is too coarse to reliably capture key mechanisms that affect groundwater age. To overcome the limits imposed by the regional grid spacing, the inset models of five basins were extracted from the LMB domain to simulate groundwater flow conditions in different glacial settings at a refined grid spacing of 500 by $500 \mathrm{ft}$, thereby allowing more precise location of wells, more precise location of surface-water features, and more detailed representation of heterogeneous glacial deposits. The added precision of the inset models was intended to strengthen the functional relations controlling the simulated time of groundwater travel to shallow glacial wells.

The inset models are intended to support a second phase of work dedicated to emulating the age findings of the numerical modeling with statistical models. The metamodeling technique is capable of distilling the correlation structures inherent in the input and output of the inset models. If the metamodels are successfully trained on the inset models and perform well in validation tests (see Fienen and others, 2016, for details on the procedure), they could potentially be used to predict groundwater age distribution in glacial wells beyond the LMB study area.

The five inset models are associated with the following 8-digit hydrologic unit code (HUC8) basins:

- the Kalamazoo basin in the Lower Peninsula of Michigan (HUC 04050003),

- the Boardman-Charlevoix basin in the Lower Peninsula of Michigan (HUC 04060105),

- the Upper Fox basin in northeastern Illinois (HUC 07120006),

- the Manitowoc-Sheboygan basin in eastern Wisconsin (HUC 04030101), and

- the combined Tacoosh-Whitefish and FishdamSturgeon basins in the Upper Peninsula of Michigan (04030111 and 04030112, respectively).

The domains of the inset models are several times larger than the areas of the basin in order to distance the constanthead boundary conditions extracted from the parent LMB model (corresponding to 2005 conditions) from the basin 
study areas and, thereby, limit the effect of the boundary conditions on the model results for the basins.

The inset models inherited many of the parent LMB model inputs, such as the hydrostratigraphy and layering scheme, the hydraulic conductivity assigned to bedrock layers, the 2005 recharge distribution, and 2005 water use in the form of pumping rates from glacial and bedrock wells. The construction of the inset models entailed modifying some inputs, most notably the grid spacing (reduced from cells $5,000 \mathrm{ft}$ on a side in the parent model to $500 \mathrm{ft}$ on a side in the inset models). The refined grid spacing allowed more precise placement of pumped wells and more detailed simulation of groundwater/surface-water interactions. The glacial hydraulic conductivity values, the top bedrock surface elevation, and the surface-water network input to the inset models also were modified. The stream network for the inset models now includes headwater streams.

The inset models were solved using the MODFLOWNewton-Raphson Solver code, which allows for more robust handling of conditions in unconfined aquifers than previous versions of MODFLOW. The inset models were informed by the calibration of the parent model but were not recalibrated for three reasons: (1) the modified input to the inset models is generally identical or similar to the parent model, (2) the water-table and water-budget conditions simulated by the parent and inset models are similar, and (3) the ultimate aim of the study - to support statistical models dependent on distilling relations inherent in correlation and sensitivity structures of the inset model - is served by the complexity and diversity of the inset models as constructed.

MODFLOW inset models incorporate a range of hydrogeologic conditions relative to the glacial part of the flow system. This range is demonstrated by visualization and analysis of many model inputs and outputs and is reflected in the spread of groundwater ages generated by MODPATH for existing and hypothetical (seeded) glacial wells. Certain inputs and outputs are judged to be candidate predictors for groundwater age and, if treated statistically, may be capable of explaining much of the variance in the simulated age metrics. One example of a predictor which model results indicate strongly influences simulated age is the depth of the well open interval below the simulated water table. In the simulations conducted with the inset models, wells in which the water table crosses the open interval yield an expected median age of 11 years; wells that are open below the water table yield an expected median age of 52 years. The strength of this example variable as an overall predictor of groundwater age and its relation to other predictors can be statistically tested through the metamodeling process. In this way the inset models are designed to serve as a training application for metamodels of groundwater age in glacial wells, which in turn will contribute to ongoing studies under the direction of the U.S. Geological Survey National Water Quality Assessment of contaminant susceptibility of shallow groundwater across the glacial aquifer system.

\section{Acknowledgments}

The content and form of the report benefitted greatly from colleague reviews performed by Chris Hoard and Zachary Stanko of the U.S. Geological Survey. The reviews were exceptionally thoughtful and thorough. Conversations with U.S. Geological Survey colleagues helped the modeling project from the beginning. In particular, we are grateful for the advice of Michael Fienen, Bernard Nolan, Jeffrey Starn, David Pollock, Kenneth Belitz, Paul Stackelberg, Sandra Eberts, Richard Yager, Randall Hunt, and Howard Reeves.

\section{References Cited}

Arihood, L.D., 2009, Processing, analysis, and general evaluation of well-driller logs for estimating hydrogeologic parameters of the glacial sediments in a ground-water flow model of the Lake Michigan Basin: U.S. Geological Survey Scientific Investigations Report 2008-5184, 26 p.

Barnes, H.H., 1967, Roughness characteristics of natural channels: U.S. Geological Survey Water-Supply Paper 1849, $213 \mathrm{p}$.

Bartošová, Alena, McConkey, Sally, Lin, Yu-Feng, and Walker, Douglas, 2004, Using NHD to estimate stream geometry characteristics for MODFLOW, in American Water Resources Association Spring Specialty Conference, Nashville, Tenn., May 17-19, 2004: Nashville, Tenn., Geographic Information Systems and Water Resources III, 7 p.

Batten, W.G., and Conlon, T.D., 1993, Hydrogeology of glacial deposits in preglacial bedrock valley, Waukesha County, Wisconsin: U.S. Geological Survey Water-Resources Investigations Report 92-4077, 15 p.

Bayless, E.R., Arihood, L.D., Reeves, H.W., Sperl, B.J., Qi, S.L., Stipe, V.E., and Bunch, A., 2017, Maps and grids of hydrogeologic information created from standardized water-well drillers' records of the glaciated United States: U.S. Geological Survey Scientific Investigations Report 2015-5105, $34 \mathrm{p}$.

Bondelid, Tim, Johnston, Craig, McKay, Cindy, Moore, Rich, and Rea, Alan, 2010, NHDPlus version 1 user guide: Prepared for U.S. Environmental Protection Agency and U.S. Geological Survey, 115 p. [Also available at http://www.horizon-systems.com/NHDPlus/NHDPlusV1_ data.php.]

Buchwald, C.A., 2009, Water use in Wisconsin, 2005: U.S. Geological Survey Open-File Report 2009-1076, 76 p. 
Buchwald, C.A., Luukkonen, C.L., and Rachol, C.M., 2010, Estimation of groundwater use for a groundwater-flow model of the Lake Michigan Basin and adjacent areas, 1864-2005: U.S. Geological Survey Scientific Investigations Report 2010-5068, 90 p.

Burow, K.R., and Belitz, Kenneth, 2014, Groundwater studies: principal aquifer surveys: U.S. Geological Survey Fact Sheet 2014-3024, 2 p.

Buschbach, T.C., 1964, Cambrian and Ordovician strata of northeastern Illinois: Illinois State Geological Survey Report of Investigation 218, $90 \mathrm{p}$.

Carlson, D.A., 2001, Dependence of conductivities and anisotropies on geologic properties within the near-surface aquifer in Milwaukee, Wisconsin: Milwaukee, Wisc., University of Wisconsin-Milwaukee (Geosciences), unpublished Ph.D. dissertation, $768 \mathrm{p}$.

Catacosinos, P.A., Westjohn, D.B., Harrison W.B., III, Wollensak, M.S., and Reynolds, R.F., 2001, Stratigraphic lexicon for Michigan: Michigan Department of Environmental Quality, Geological Survey Division Bulletin 8, 56 p.

Doherty, John, and Hunt, R.J., 2010, Approaches to highly parameterized inversion-A guide to groundwater model calibration using PEST: U.S. Geological Survey Scientific Investigations Report 2010-5169, 59 p.

Doherty, John, and Welter, David, 2010, A short exploration of structural noise: Water Resources Research, v. 46, no. 5, 14 p., https://doi.org/10.1029/2009WR008377.

Eberts, S.M., Thomas, M.A., and Jagucki, M.L., 2013, The quality of our Nation's waters: factors affecting publicsupply-well vulnerability to contamination: understanding observed water quality and anticipating future water quality: U.S. Geological Survey Circular 1385, 120 p.

Feinstein, D.T., Fienen, M.N., Kennedy, J.L., Buchwald, C.A., and Greenwood, M.M., 2012, Development and application of a groundwater/surface-water flow model using MODFLOW-NWT for the Upper Fox River Basin, Southeastern Wisconsin: U.S. Geological Survey Scientific Investigations Report 2012-5108, $124 \mathrm{p}$.

Feinstein, D.T., Fienen, M.N., and Reeves, Howard, 2017, What makes a MODFLOW-derived metamodel useful in decision support? [abs.]: Proceedings of the MODFLOW and More 2017 conference, May 21-24, 2017, Colorado School of Mines, Golden, Colo., 84 p.

Feinstein, D.T., Fienen, M.N., Reeves, H.W., and Langevin, C.D., 2016, A semi-structured MODFLOW-USG model to evaluate local water sources to wells for decision support: Groundwater, v. 54, no. 4, p. 532-544, accessed November 25, 2016, at http://onlinelibrary.wiley.com/doi/10.1111/ gwat.12389/abstract.
Feinstein, D.T., Hunt, R.J., and Reeves, H.W., 2010, Regional groundwater-flow model of the Lake Michigan Basin in support of Great Lakes Basin water availability and use studies: U.S. Geological Survey Scientific Investigations Report 2010-5109, 379 p.

Fienen, M.N., Nolan, B.T., and Feinstein, D.T., 2016, Evaluating the sources of water to wells-Three techniques for metamodeling of a groundwater flow model: Environmental Modelling and Software, v. 77, p. 95-107, https://doi.org/10.1016/j.envsoft.2015.11.023.

Fienen, M.N., Nolan, B.T., Feinstein, D.T., and Starn, J.J., 2015, Metamodels to bridge the gap between modeling and decision support: Groundwater, v. 53, no. 4, p. 511-512, https://doi.org/10.1111/gwat.12339.

Fullerton, D.S., Bush, C.A., and Pennell, J.N., 2003, Map of surficial deposits and materials in the eastern and central United States (east of $102^{\circ}$ west longitude): U.S. Geological Survey Geologic Investigations Series I-2789, 46 p.

Gray, H.H., Droste, J.B., Patton, J.B., Rexroad, C.B., and Shaver, R.H., 1985, Correlation chart showing Paleozoic supplement stratigraphic units of Indiana: Indiana Geological Survey Miscellaneous Map 48.

Harbaugh, A.W., Banta, E.R., and McDonald, M.C., 2000, MODFLOW-2000, the U.S. Geological Survey modular ground-water model-User guide to modularization processes and the ground-water flow process: U.S. Geological Survey Open-File Report 2000-92, 121 p.

Haserodt, M.J., Kauffman, L.J., and Feinstein, D.T., 2018, MODFLOW-NWT inset models from the regional Lake Michigan Basin Model in support of groundwater age calculations for glacial aquifers: U.S. Geological Survey data release, https://doi.org/10.5066/F76D5R5V.

Hill, M.C., 1990, Preconditioned conjugate-gradient 2 (PCG2), a computer program for solving ground-water flow equations: U.S. Geological Survey Water-Resources Investigations Report 90-4048, 43 p.

Hull, D.N., 1990 (compiler), revised by Larson, G.E., 2000, and Slucher, E.R., 2004, Generalized column of bedrock units in Ohio: Ohio Department of Natural Resources, Division of Geological Survey, accessed April 6, 2018, at http://geosurvey.ohiodnr.gov/portals/geosurvey/PDFs/ Misc_State_Maps\&Pubs/stratcol.pdf.

Hunt, R.J., Doherty, J., and Tonkin, M.J., 2007, Are models too simple? Arguments for increased parameterization: Groundwater, v. 45, no. 3, p. 254-263, https://doi.org/10.1111/j.1745-6584.2007.00316.x. 
Hunt, R.J., Prudic, D.E., Walker, J.F., and Anderson, M.P., 2008, Importance of unsaturated zone flow for simulating recharge in a humid climate: Groundwater, v. 46, no. 4, p. 551-560, https://doi.org/10.1111/j.17456584.2007.00427.x.

Jones, E., Oliphant, E., Peterson, P., and others, 2001-16, Scipy-Open source scientific tools for Python, accessed May 13, 2016, at http://www.scipy.org.

Juckem, P.F., Clark, B.R., and Feinstein, D.T., 2017, Simulation of groundwater flow in the glacial aquifer system of northeastern Wisconsin with variable model complexity: U.S. Geological Survey Scientific Investigations Report 2017-5010, 52 p., https://doi.org/10.3133/sir20175010.

Kitanidis, P.K., 1997, Introduction to Geostatistics-Applications in hydrogeology: Cambridge, United Kingdom, Cambridge University Press, 249 p.

Kolata, D.R., 1990, Overview of sequences. in Leighton, M.W., Kolata, D.R., Oltz, D.F., and Eidel, J.J., eds., Interior cratonic basins: Tulsa, Okla., American Association of Petroleum Geologists Memoir 51, p. 59-73.

Kolata, D.R., and Graese, A.M., 1983, Lithostratigraphy and depositional environments of the Maquoketa Group (Ordovician) in northern Illinois: Illinois State Geological Survey Circular 528, 49 p.

Konikow, L.F., Hornberger, G.Z., Halford, K.J., and Hanson, R.T., 2009, Revised multi-node well (MNW2) package for MODFLOW ground-water flow model: U.S. Geological Survey Techniques and Methods, book 6, chap. A30, 67 p.

Kresic, N., 2007, Hydrogeology and groundwater modeling (2d edition): CRC Press, Boca Raton, Fla., 807 p.

Lampe, D.C., 2009, Hydrogeologic framework of bedrock units and initial salinity distribution for a simulation of ground-water-flow for the Lake Michigan Basin: U.S. Geological Survey Scientific Investigations Report 2009-5060, 49 p.

Langevin, C.D., Shoemaker, W.B., and Guo, Weixing, 2003, MODFLOW-2000, the U.S. Geological Survey modular ground-water model-Documentation of the SEAWAT-2000 version with the Variable-Density Flow Process (VDF) and the Integrated MT3DMS Transport Process (IMT): U.S. Geological Survey Open-File Report 03-426, $43 \mathrm{p}$.

Langevin, C.D., Thorne, D.T., Jr., Dausman, A.M., Sukop, M.C., and Guo, Weixing, 2007, SEAWAT Version 4-A computer program for simulation of multi-species solute and heat transport: U.S. Geological Survey Techniques and Methods, book 6, chap. A22, 39 p.
Mikulic, D.R., Sargent, M.L., Norby, R.D., and Kolata, D.R., 1985, Silurian geology of the Des Plaines River valley, northeastern Illinois: Illinois State Geological Survey Guidebook 17, 56 p.

Niswonger, R.G., Panday, S., and Ibaraki, M., 2011, MODFLOW-NWT, A Newton formulation for MODFLOW-2005: U.S. Geological Survey Techniques and Methods, book 6, chap. A37, 44 p.

Niswonger, R.G., and Prudic, D.E., 2005, Documentation of the Streamflow-Routing (SFR2) Package to include unsaturated flow beneath streams-A modification to SFR1: U.S. Geological Survey Techniques and Methods, book 6, chap. A13, $50 \mathrm{p}$.

Pollock, D.W., 2012, User guide for MODPATH version 6-A particle-tracking model for MODFLOW: U.S. Geological Survey Techniques and Methods, book 6, chap. A41, 58 p.

Prudic, D.E., Konikow, L.F., and Banta, E.R., 2004, A new Streamflow-Routing (SFR1) Package to simulate streamaquifer interaction with MODFLOW-2000: U.S. Geological Survey Open-File Report 2004-1042, 35 p.

Rumbaugh, J.O., and Rumbaugh, D.B., 2011, Command references for Groundwater Vistas, version 6: Reinholds, Pa., Environmental Simulations, Inc., 377 p.

Soller, D.R., and Packard, P.H., 1998, Digital representation of a map showing the thickness and character of Quaternary sediments in the glaciated United States east of the Rocky Mountains: U.S. Geological Survey Digital Data Series DDS-38.

Starn, J.J., Bagtzoulou, A.C., and Robbins, G.A., 2012, Methods for simulating solute breakthrough curves in pumping groundwater wells: Computers \& Geosciences, v. 48, p. 244-255.

U.S. Geological Survey, 2006, 1:250,000-scale hydrologic units of the United States - Downloadable base map accessed February 12, 2017, at https://water.usgs.gov/GIS/ metadata/usgswrd/XML/huc250k.xml.

U.S. Geological Survey, 2014, National Elevation Dataset (NED) 1/3 arc-second-Downloadable data collection: accessed May 28, 2015, at https://www.sciencebase.gov/ catalog/item/4f70aa9fe4b058caae3f8de5.

U.S. Geological Survey, 2016, Watershed boundary dataset: accessed December 28, 2016, at https://nhd.usgs.gov/wbd. html.

Westenbroek, S.M., Kelson, V.A., Dripps, W.R., Hunt, R.J., and Bradbury, K.R., 2009, SWB-A modified Thornthwaite-Mather soil-water balance code for estimating groundwater recharge: U.S. Geological Survey Techniques and Methods, book 6, chap. A31, 65 p. 
Willman, H.B., Atherton, E., Buschbach, T.C., Collinson, C., Frye, J.C., Hopkins, M.E., Lineback, J.A., and Simon, J.A., 1975, Handbook of Illinois stratigraphy: Illinois State Geological Survey Bulletin 95, $261 \mathrm{p}$.

Wisconsin Geological and Natural History Survey, 2006, Bedrock stratigraphic units in Wisconsin: Wisconsin Geological and Natural History Survey Open-File Report 2006-06, 1 p.

Wolock, David, 2003, Estimated mean annual natural groundwater recharge in the conterminous United States: U.S. Geological Survey Open-File Report 2003-311, Raster digital data at https://water.usgs.gov/lookup/getspatial?rech48grd.

Young, H.L., and Siegel, D.I., 1992, Hydrogeology of the Cambrian-Ordovician aquifer system in the northern Midwest, United States: U.S. Geological Survey Professional Paper 1405-B, 99 p.

Zheng, Chunmiao, 1994, Analysis of particle tracking errors associated with spatial discretization: Groundwater, v. 32, no. 5 , p. $821-828$.

Zheng, Chunmiao, Bianchi, Marco, and Gorelick, Steven, 2010, Lessons learned from 25 years of research at the MADE site: Groundwater, v. 45, no. 5, p. 649-662, https:///doi.org/10.1111/j.1745-6584.2010.00753.x.

Zheng, Chunmiao, and Wang, P.P., 1999, MT3DMS-A modular three-dimensional multi-species transport model for simulation of advection, dispersion, and chemical reactions of contaminants in groundwater systems; documentation and user's guide: Contract report SERDP-99-1: Vicksburg, Miss., U.S. Army Corps of Engineers, Engineer Research and Development Center, $169 \mathrm{p}$. 
For additional information concerning this publication, contact: Director, USGS Upper Midwest Water Science Center 8505 Research Way

Middleton, WI 53562

(608) 828-9901

Or visit the Upper Midwest Water Science Center website at: https://wi.water.usgs.gov

Publishing support provided by the Madison, Rolla, and Pembroke Publishing Service Centers 


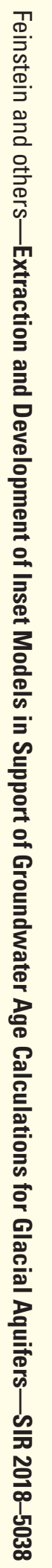

Printed on recycled paper 